\title{
AVALIAÇÃO DE IMPACTO AMBIENTAL COMO INSTRUMENTO DE POLÍTICAS PÚBLICAS: ANÁLISE DE PROBLEMAS E ESTUDO DE CASO EM ÁREA DE MINERAÇÃO NO ESTADO DO PARÁ
}

\author{
ANA CLARA SERRÃO FAYAL \\ Socióloga
}

Orientador: Prof. Dr. ALVARO FERNANDO DE ALMEIDA

\begin{abstract}
Dissertação apresentada à Escola Superior de Agricultura "Luiz de Queiroz", Universidade de São Paulo, para obtenção do título de Mestre em Recursos Florestais, com opção em Conservação de Ecossistemas Florestais.
\end{abstract}

P I R A C I C A B A

Estado de São Paulo - Brasil

Agosto - 2003 


\section{Dados Internacionais de Catalogação na Publicação (CIP) DIVISĀO DE BIBLIOTECA E DOCUMENTAÇĀO - ESALQ/USP}

Fayal, Ana Clara Serrão Avaliação de impacto ambiental como instrumento de políticas públicas: análise de problemas e estudo de caso em área de mineração no Estado do Pará / Ana Clara Serrão Fayal. - - Piracicaba, 2003. $219 \mathrm{p}$.

Dissertação (mestrado) - Escola Superior de Agricultura Luiz de Queiroz, 2003.

Bibliografia.

1. Área conservação 2. Impacłos ambientais - Avaliação 3. Mineração 4. Políticas públicas I. Título

CDD 333.714

\section{Termitida a cópia total ou parcial deste documento, desde que citada a fonte -0 autor}




\section{ERRATA}

\begin{tabular}{|c|c|c|c|c|}
\hline p. & ítem & linha & onde se lê & leia-se \\
\hline XVIII & 13 & & .......operaçã & ..........operação \\
\hline XVIII & título & 3 & $\begin{array}{l}\text { Avaliação de Impacto Ambiental como } \\
\text { instrumento de Políticas Públicas: Análise de } \\
\text { Problemas e Estudo de Caso em Área de no } \\
\text { Estado do Pará. }\end{array}$ & $\begin{array}{l}\text { Avaliação de Impacto Ambiental como } \\
\text { instrumento de Políticas Públicas: Análise } \\
\text { de Problemas e Estudo de Caso em Ârea } \\
\text { de Mineração no Estado do Pará. }\end{array}$ \\
\hline $\mathrm{XX}$ & tílulo & & $\begin{array}{l}\text { Emvironmental Impact Evaluation as Public } \\
\text { Policy Tool: Problemas Analysis and Case } \\
\text { Study in an area at Para State. }\end{array}$ & $\begin{array}{l}\text { Environmental Impact Evaluation as } \\
\text { Public Policy Tool: Problemas Analysis } \\
\text { and Case Study in an Mining atea at Para } \\
\text { State. }\end{array}$ \\
\hline 1 & introdução & $\begin{array}{c}7-1^{\circ} \\
\text { parágrafo }\end{array}$ & .....significadamente & .........significativamente \\
\hline 4 & 1.1 & $\begin{array}{c}4-3^{\circ} \\
\text { parágrafo }\end{array}$ & .... das populaçves & ....... da população \\
\hline 7 & 1.3 .2 & $\begin{array}{c}\text { 6- } 6^{\circ} \\
\text { parágrafo }\end{array}$ & .......as qualidades & ........ a qualidade \\
\hline 31 & 2.2 & $\begin{array}{l}10,11-2^{\circ} \\
\text { parágrafo }\end{array}$ & ... plano de recuperação de área degradada & $\begin{array}{l}\text { (......planos de recuperação de áreas } \\
\text { degradadas }\end{array}$ \\
\hline 32 & 2.2 & \begin{tabular}{|c|}
$6-3^{\circ}$ \\
parágrafo \\
\end{tabular} & $\ldots \ldots$ & suprir a virgula e coloca-se ponto \\
\hline 35 & 2.2 & $\begin{array}{l}5-4^{\circ} \\
\text { parágrafo }\end{array}$ & $\begin{array}{l}\text { …...... como de eliminar a influência tanto de } \\
\text { grupos políticos como de grupos econômicos }\end{array}$ & $\begin{array}{l}\text {......de grupos políticos como de grupos } \\
\text { econômicos }\end{array}$ \\
\hline 45 & 3.1 .6 & $\begin{array}{c}3-1^{\circ} \\
\text { parágrafo }\end{array}$ & ........Este & ...... Esta \\
\hline 48 & 4.2 & $\begin{array}{c}3-1^{\circ} \\
\text { parágrato }\end{array}$ & ........ à pesquisa & ...... a pesquisa \\
\hline 53 & 4.5 & $\begin{array}{c}3-3^{\circ} \\
\text { parágralo }\end{array}$ & $\begin{array}{l}\text {.... considerações referentes ao estudo de } \\
\text { realizado }\end{array}$ & $\begin{array}{l}\text {.............. considerações referentes ao } \\
\text { estudo realizado }\end{array}$ \\
\hline 55 & 4.5 & letra "d" & ........Lei $237 / 97$ & ....... Resolução $237 / 97$ \\
\hline 56 & 7.1 & $\begin{array}{c}6-7^{\circ} \\
\text { parágrafo }\end{array}$ & ......... seguir. & …....seguir: \\
\hline 83 & 8.1 & $\begin{array}{l}\text { figura } 3 \\
\text { quarta } \\
\text { coluna }\end{array}$ & ....... Pos-doctor & ........Pós-Doctor \\
\hline 83 & 8.1 & $\begin{array}{l}\text { figura } 4 \\
\text { quarta } \\
\text { coluna }\end{array}$ & ...... Minas geruis & ........Minas Gerais \\
\hline 83 & 8.1 & $\begin{array}{l}\text { figura } 4, \\
\text { quinta } \\
\text { coluna }\end{array}$ & .........Rio granoe do sul & ..........Rio Grande do Sul \\
\hline 83 & 8.1 & figura 4 & ........ Naturalidade dos especialistas & ........ Origem dos especialistas \\
\hline 95 & 8.1 .6 & $\begin{array}{c}2-2^{\circ} \\
\text { parágrafo }\end{array}$ & ....... efetiva na sociedade, mas por lado & $\begin{array}{l}\text {........ efetiva da sociedade, mas por outro } \\
\text { lado }\end{array}$ \\
\hline 96 & 8.1 .6 & $\begin{array}{l}6 b-2^{a} \\
\text { coluna }\end{array}$ & ....... participaçâo & .......participação da sociedade \\
\hline 110 & 8.1 .8 & $\begin{array}{c}2-4^{\circ} \\
\text { parágrafo }\end{array}$ & ............. a fruticultora & ..... a fruticultura \\
\hline 111 & 8.1 .8 & $\begin{array}{c}4-5^{\circ} \\
\text { parágrafo }\end{array}$ & .......... projetado & ........ projeto \\
\hline 112 & 8.1 .8 & $\begin{array}{c}10-3^{\circ} \\
\text { parágrafo }\end{array}$ & ...... fisicas & ........ física \\
\hline 134 & 8.1 .21 & $\begin{array}{c}1-1^{\circ} \\
\text { parágrafo }\end{array}$ & $\begin{array}{l}\text {...... Este é ou repiovação dos grandes } \\
\text { projetos. }\end{array}$ & ...... desconsiderar esta frase no tex.o. \\
\hline 134 & 8.1 .21 & $\begin{array}{c}6-1^{\circ} \\
\text { parágrafo }\end{array}$ & $\begin{array}{l}\text {..... ocorre. ass'mto bem delicado, relaciona-se } \\
\text { aos interesses que estão por traz da aprovação }\end{array}$ & $\begin{array}{l}\text {............ ocorre assunto bem delicado, } \\
\text { relaciona-se aos interesses que estão por } \\
\text { traz da aprovação. }\end{array}$ \\
\hline 134 & 8.1 .21 & $\begin{array}{c}2-3^{\circ} \\
\text { parágrafo }\end{array}$ & ........quer mais & .... que mais \\
\hline 141 & $\begin{array}{c}\text { Referências } \\
\text { Bibliográficas }\end{array}$ & $3^{\text {a }}$ citação & ...........Economies & ........Economies \\
\hline
\end{tabular}


Aos meus pais, Milton Fayal (in

memorian) e Inêz Serrão Fayal, pelo

amor, exemplo de luta e apoio constante.

\section{ofereço}

(... a Natureza fez tudo a nosso favor, nós porém pouco ou nada temos feito a favor da Natureza. Nossas terras estão ermas, e as poucas que temos roteado são mal cultivadas, porque o são por braços indolentes e forçados. Nossas numerosas minas, por falta de trabalhadores ativos e instruidos, estão desconhecidas ou mal aproveitadas. Nossas preciosas matas vão desaparecendo, vítimas do fogo e do machado destruidor da ignorância e do egoísmo. Nossos montes e encostas vão se escalvando diariamente, e com o andar do tempo faltarão as chuvas fecundantes que favoreçam a vegetação $e$ alimentem nossas fontes e rios, sem o que o nosso belo Brasil, em menos de dois séculos, ficará reduzido aos páramos e desertos áridos da Líbia. Virá então este dia (dia terrivel e fatal), em que a ultrajada natureza se ache vingada de tantos erros e crimes cometidos."

(José Bonifácio de Andrade e Silva,1823)

A todos aqueles que de alguma forma têm contribuído para conservação da natureza e a proteção ambiental na Terra.

\section{Dedico}




\section{AGRADECIMENTOS}

Agradeço a Deus pelo seu amor incondicional.

Ao meu orientador e amigo Prof. Dr. Alvaro Fernando de Almeida, por sua valiosa orientação, apoio, confiança e pelo tempo, pacientemente dedicado, a tantas dúvidas surgidas no caminho, o qual desde do início tem sido um grande mestre amigo, e por me ouvir nos momentos de tristeza e alegria, e por fazer acreditar que vale a pena insistir e lutar perante as tempestades da vida.

À Inêz, minha mãe, agradeço especialmente por toda a esperança que me fez ter com o apoio, o incentivo e orações que, somente uma mãe abençoada como a senhora, poderia dar.

Aos meus pais: Milton Fayal (in Memorian) e Inêz Fayal, meus irmãos e irmãs: Carlota, Guilhermina, Joana, Maria Eufrauzina, Icléia, Ademar, Adriano, João Antônio, Brasil e Simião e aos meus sobrinhos: Marcelo, Giovanna Fayal, Natália, Eduardo, Ana Alzira, Armando, Alberto, Nadson, Saula, Saissy, Marcio, Mara, Marcos, Goreth,

Arlena, Júnior, Vinicius Fayal, Ingrid, Barbara, Eval, pelo amor, carinho, amizade, apoio... tantas coisas... que me faltam palavras e formas para agradecer.

Ao Diretor Operacional da Mineração Serra do Sossego (MSS), Dr. Rafael Bloise por ter permitido a coleta dos dados.

À Rosa Itapema Silveira, Newton Silveira, Valdir Akihiko Nakazawa e Marcia Piacentini pela amizade, companheirismo e imensa ajuda prestada solidariedade nos momentos finais da minha dissertação.

Aos Prof. Sérgio Gandolfi e Fabiola Zioni pela amizade, e pelas discussões e orientação durante o mestrado. Aos amigos Francisco Fonseca, Cely Menezes, Marcia 
Lobo, Isabel Reis, Lilian, Edna Corumbá, Perminio Paschoal, Ana Mesquita e Inácio Farias Serrão (tio) pela sua amizade e ajuda em todos os momentos da minha vida.

À Cristiane Almeida, pela amizade e companheirismo durante a minha estadia em Piracicaba.

Aos professores e funcionários do Departamento de Ciências Florestais, pelos auxílios prestados.

Aos queridos amigos, que me propiciaram carinho, apoio e amizade, ou seja, tudo que se precisa para um bom convívio: Prof. Dr Marcos Sorrentino, Simone, Prof. Dr. Mário Tomazzelo, Adriana (Cema), Walcylene Lacerda, Rosane Rodrigues, Jorge Soares, Carga Gheler, Adriana (bolacha), Ana, Rose (Biométrica), Alexandre Almeida, Michelle Costa, Vânia, Juliana, Lúcia, Lilian, Claúdia Lira, Clariça, Maria Claúdia, Winter e Viviane, Percy, Fábio, Dr. João (ESALQ), Rosângela, José Martins e Wirifram.

Ao Departamento de Ciências Florestais da ESALQ/USP, por possibilitar a realização do curso de pós-graduação.

À CAPES pela bolsa de estudos concedida.

À Secretaria Executiva de Ciência, Tecnologia e Meio Ambiente - SECTAM/PA, por ter permitido o levantamento dos dados.

Aos companheiros de pós-graduação pelas contribuições na discussão da pesquisa, apoio e solidariedade nos momentos difíceis.

Ao Marcelino, pela ajuda, paciência e amizade no decorrer do mestrado.

A Andreia Mosca, pela imensa ajuda prestada e solidariedade nos momentos finais da minha dissertação.

Ao Alexandre halle Najm, Rogério Naressi, Evandro Dell, Margarete Pinese e Jefferson Polizel pela amizade, paciência e prontidão.

Aos profissionais que participaram desta pesquisa, respondendo aos questionários e apresentando preciosas sugestões, que foram fundamentais para o alcance dos resultados almejados. 


\section{SUMÁRIO}

Página

LISTA DE FIGURAS ...............................................................................

LISTA DE QUADROS .............................................................................. xiii

LISTA DE SIGLAS E ABREVIATURAS ..................................................... xv

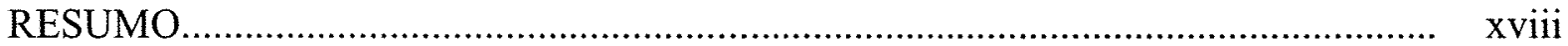

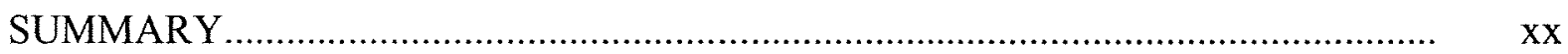

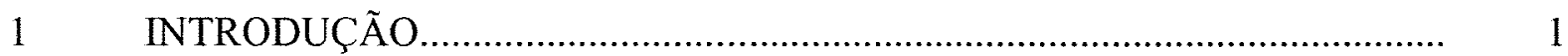

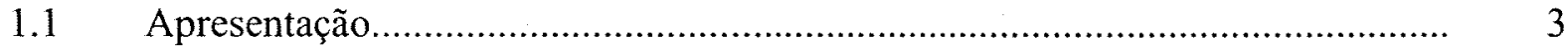

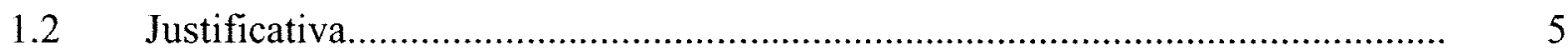

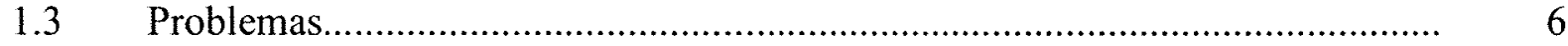

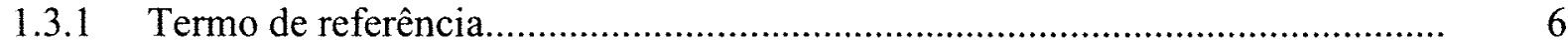

1.3.2 Custos de elaboração do EIA ..................................................................... 7

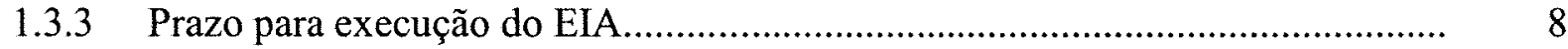

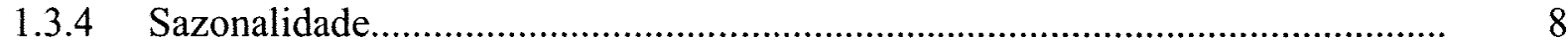

1.3.5 Unidades de Conservação e Reservas Indígenas.......................................... 8

1.3.6 Participação da sociedade civil em audiências públicas................................. 9

1.3.7 Compensação ambiental relativa à implantação de grandes projetos................ 9

1.3.8 Levantamento socioeconômico para estudo de impacto ambiental................... 9

1.3.9 Acompanhamento da execução das medidas mitigadoras, da verificação do cumprimento das exigências das licenças, dos programas de 
monitoramento e dos programas de recuperação................................................ 10

1.3.10 Conflito de competências quanto ao licenciamento ambiental........................... 10

1.3.11 Coordenação e formação da equipe multidisciplinar.............................................. 10

1.3.12 Ausência de um banco de dados nos órgãos ambientais..................................... 10

1.3.13 Remuneração salarial, capacitação dos técnicos dos órgãos ambientais e avaliação do EIA/RIMA (equipe externa de consultoria).................................. 11

1.3.14 Relacionamentos entre empreendedor, órgão ambiental e entidades de meio ambiente................................................................................................ 11

1.3.15 Carência de empresas habilitadas.................................................................... 11

1.3.16 Divulgação e acesso às informações dos estudos de impacto ambiental............. 12

$1.4 \quad$ Hipótese de Trabalho.................................................................................. 12

$1.5 \quad$ Objetivo geral..................................................................................... 12

1.6 Objetivos Específicos........................................................................... 13

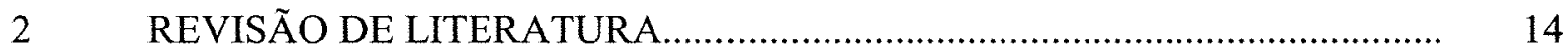

2.1 Avaliação de impactos ambientais (AIA) .......................................................... 14

2.2 Estudo de impacto ambiental e relatório de impacto ambiental sobre o meio ambiente (EIA/RIMA) ............................................................................. 29

2.3 O Ministério Público e o estudo de impacto ambiental ..................................... 39

3 MATERIAL E MÉTODOS....................................................................... 40

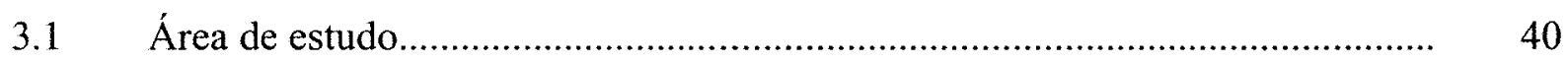

3.1.1 Caracterização da área de estudo...................................................................... 41

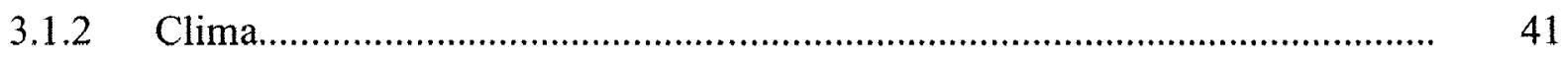

3.1.3 Geologia

3.1.4 Geologia regional................................................................................ 42

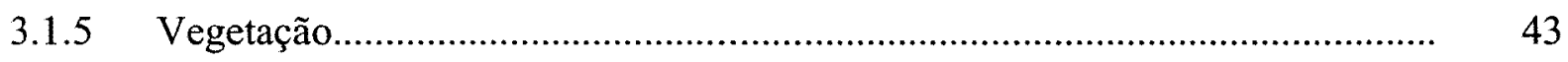

3.1.6 Aspectos socioeconômicos da região do projeto................................................... 44

$4 \quad$ Procedimentos Metodológicos....................................................................... 46

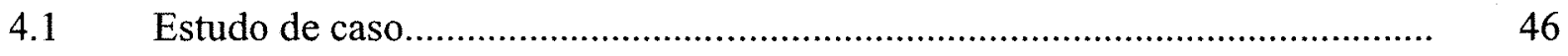

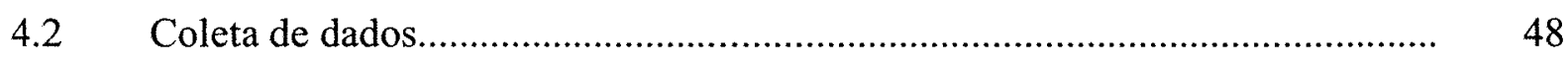

$4.3 \quad$ Pesquisa qualitativa.................................................................................... 50 


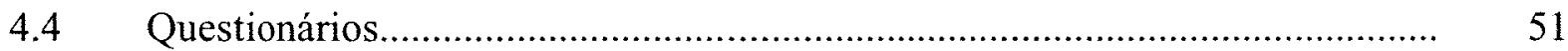

4.5 Análise e interpretação dos dados............................................................... 52

$5 \quad$ Principais documentos examinados.............................................................. 55

$5.1 \quad$ O estudo de impacto ambiental (EIA/RIMA) ………................................... 55

6 Descrição do empreendimento...................................................................... 56

$7 \quad$ Descrição dos impactos ambientais................................................................. 56

7.1 Etapa de implantação....................................................................................... 56

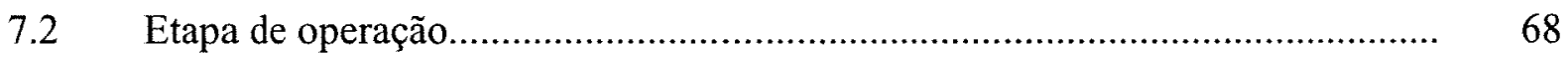

7.3 Etapa de fechamento..................................................................................

7.4 Programas de mitigação e monitoramento......................................................... 77

7.5 Medidas de mitigação dos impactos.................................................................. 79

8 RESULTADOS E DISCUSSÃO.............................................................. 82

8.1 Público alvo............................................................................................ 82

8.1.1 Qualidade dos termos de referência............................................................... 85

8.1.2 Recursos financeiros destinados à elaboração dos EIA/RIMA............................ 87

8.1.3 Prazos para execução do EIA...................................................................... 91

8.1.4 Os EIA quanto a sazonalidade dos estudos em ambientes complexos............... 92

8.1.5 Realização de estudos ambientais para unidades de conservação ou reserva

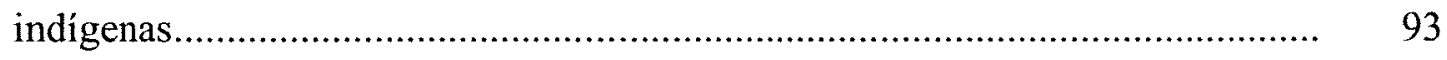

8.1.6 Os EIA a participação da sociedade civil em audiências públicas..................... 95

8.1.7 A implantação de grandes projetos, deve propiciar uma compensação

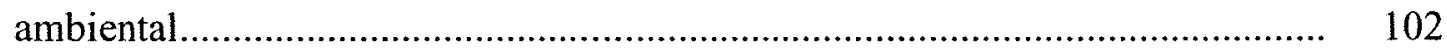

8.1.8 Os levantamentos socioeconômicos para os EIA/RIMA ……………………... 104

8.1.9 Os acompanhamento da execução das medidas mitigadoras, compensatórias dos monitoramentos e recuperação de áreas degradadas.

8.1.10 Conflito de competências em relação ao licenciamento ambiental entre a SECTAM e o IBAMA ………………………….................................... 117

8.1.11 Licença prévia e de instalação......................................................................... 118

8.1.12 Coordenação e formação de equipes multidisciplinares nos EIA/RIMA........... 121

8.1.13 Banco de dados nos órgãos ambientais e as empresas consultoras.................... 122 


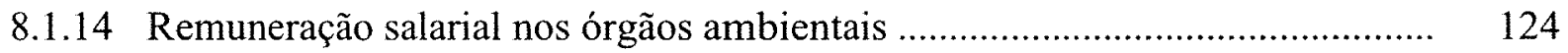

8.1.15 Órgãos ambientais e a contratação de consultoria ambiental externa................. 125

8.1.16 Os relacionamentos entre empreendedores, órgãos ambientais e ONG's, quanto à gestão de EIA/RIMA ......................................................... 126

8.1.17 As possíveis carências técnicas de empresas habilitadas................................ 127

8.1.18 Divulgação e acesso às informações dos Estudos de Impacto Ambiental concluído................................................................................... 128

8.1.19 Os programas de controle ambiental..................................................... 130

8.1.20 A Resolução 001/86 quanto à elaboração dos EIA/RIMA ............................... 131

8.1.21 Os grandes interesses nos EIA/RIMA de grandes projetos......................... 134

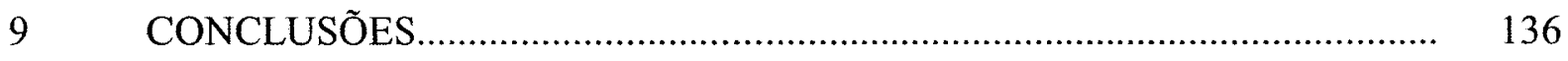

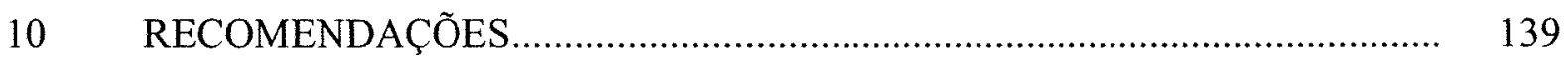

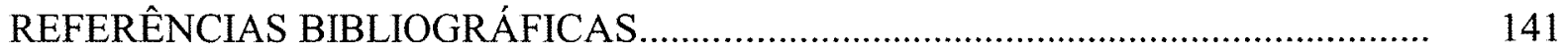

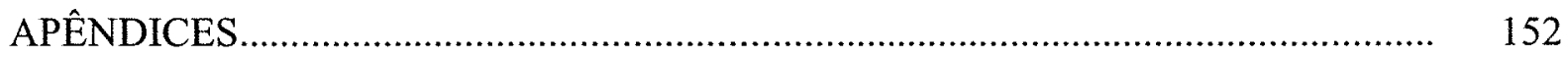




\section{LISTA DE FIGURAS}

\section{Página}

1 Processo de avaliação de impacto ambiental............................................................ 25

2 Localização do Projeto Sossego, junto ao Alvo Sequeirinho no município de Canaã dos Carajás em relação à estação de embarque em Paraupebas. Os dois outros polígonos demarcados referem ao Alvo Serra Dourada (Canaã dos Carajás) e Alvo Canadá no município de Água Azul do Norte, localizados ao sul da Serra de Carajás, região sudeste do Estado do Pará

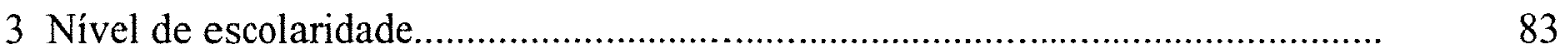

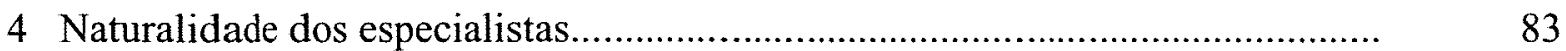

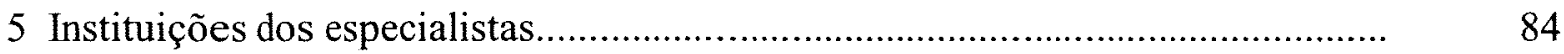

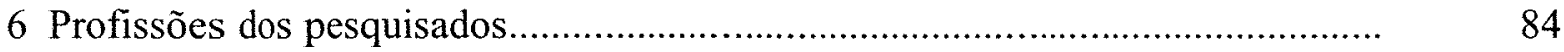

7 Recursos financeiros destinados à elaboração dos EIA/RIMA................................

8 Recursos financeiros destinados à elaboração dos EIA/RIMA.............................

9 Recursos financeiros destinados à elaboração dos EIA/RIMA.................................... 90

10 Recursos financeiros destinados à elaboração dos EIA/RIMA..............................

11 Prazos para execução e elaboração do EIA/RIMA.................................................

12 Prazos para execução e elaboração do EIA/RIMA.............................................

13 Realização de estudos ambientais de acordo com a sazonalidade.......................... 93

14 Área de influência direta das Unidades de Conservação e/ou Reserva Indígenas 
15 Participação da sociedade civil em audiências públicas....................................... 96

16 Reuniões preparatórias para audiências públicas.................................................. 96

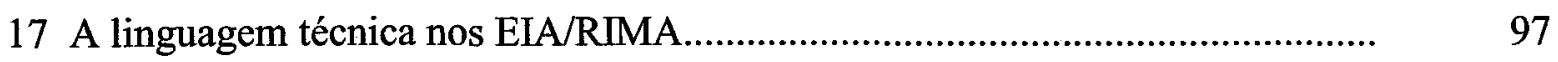

18 Participação da sociedade civil em audiências públicas........................................ 98

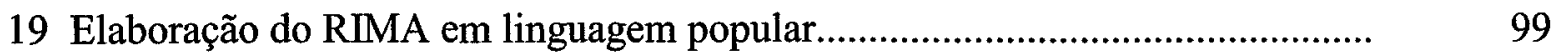

20 Compensação ambiental para Unidades de Conservação..................................... 104

21 Levantamento socioeconômico para EIA/RIMA.................................................. 113

22 Os EIA/RIMA e o levantamento socioeconômico................................................ 114

23 Acompanhamento e execução das medidas mitigadoras e dos programas de monitoramento

24 Acompanhamento e execução das medidas mitigadoras e dos programas de monitoramento

$25 \mathrm{O}$ conflito quanto ao licenciamento ambiental................................................... 118

26 Emissões das licenças ambientais................................................................... 120

27 A coordenação de equipes multidisciplinares....................................................... 122

28 Os bancos de dados nos órgãos ambientais........................................................ 123

29 A remuneração salarial nos órgãos ambientais.................................................... 124

30 A contratação de consultoria ambiental externa para elaboração de EIA/RIMA 125

31 Os relacionamentos entre os agentes envolvidos............................................... 127

32 A carência de empresas de consultoria ambiental.............................................. 128

33 Divulgação das informações sobre EIA/RIMA....................................................... 129

34 Os programas de controle ambiental........................................................... 131

35 A Resolução 001/86 referente a EIA/RIMA........................................................ 133 


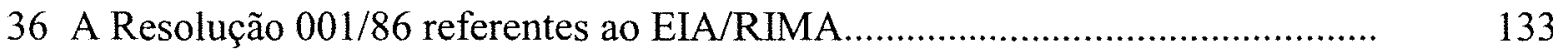

37 Interesses ligados a grandes projetos.................................................... 134 


\section{LISTA DE QUADROS}

Página

1 Intensidade dos impactos ambientais (fase de implantação)...................................

2 Abrangência dos impactos ambientais (fase de implantação)................................ $\quad 57$

3 Significância dos impactos ambientais (fase de implantação)................................ 58

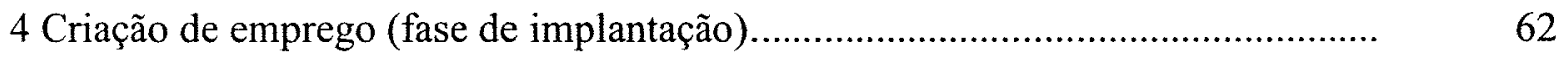

5 Geração de renda e tributos (fase de implantação)......................................................... 63

6 Aumento da população e ocupação desordenada (fase de implantação)................ 63

7 Sobrecarga na infra-estrutura de serviços e equipamentos públicos (fase de

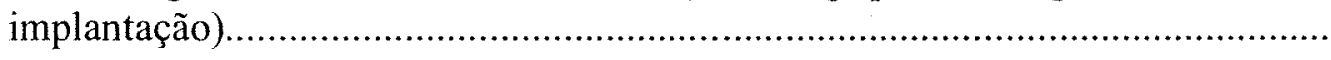

8 Incrementos de problemas de saúde e segurança pública (fase de implantação).. $\quad 65$

9 Melhoramentos na infra-estrutura rodoviária (fase de implantação)....................... 66

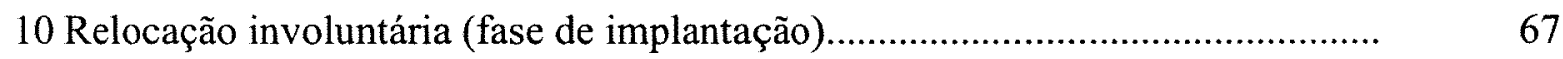

11 Resumo de avaliação de impacto real na etapa de implantação da Mineração Serra do Sossego - etapa de implantação (fase de implantação).......................... 67

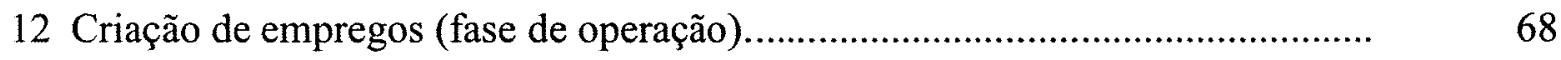

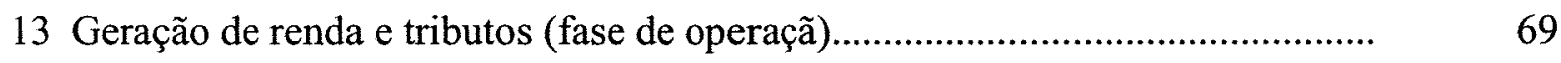

14 Garantia de acesso em virtude da rodovia (fase de operação)............................ $\quad 70$

15 Impacto de incômodos e riscos relacionados à operação da rodovia (fase de

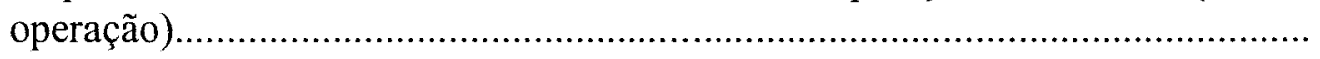


16 Oferta do cobre no mercado nacional e internacional (fase de operação)...........

17 Incremento de negócios e da importância política da área (fase de operação)....

18 Ocupação desordenada, incremento de problemas de saúde e segurança (fase de operação).

19 Resumo de avaliação de impacto real na etapa de operação Mineração Serra do Sossego (etapa de operação).

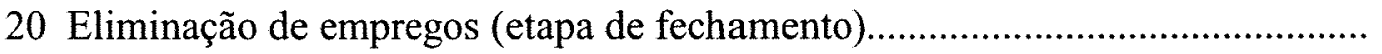

21 Redução de renda e tributos (etapa de fechamento).

22 Redução dos incômodos e riscos relacionados à operação da rodovia (etapa de fechamento)

23 Redução na oferta do cobre no mercado nacional e internacional (etapa de fechamento).

24 Redução de negócios na área (etapa de fechamento).

25 Resumo de avaliação de impacto real na etapa de desativação - Mineração Serra do Sossego (etapa de fechamento).

26 Programas de mitigação e monitoramento (etapa de implantação)

27 Relação entre os impactos prognosticados e as medidas de mitigação propostas (etapa de operação).

28 Relação entre os impactos prognosticados e as medidas de mitigação propostas (etapa de desativação). 


\section{LISTA DE ABREVIATURAS E SIGLAS}

AAE - Avaliação Ambiental Estratégica

ABES - Associação Brasileira de Engenharia Sanitária e Ambiental

ABNT- Associação Brasileira de Normas Técnicas

AIA - Avaliação de Impacto Ambiental

AID - Área de Influência Direta

AII - Área de Influência Indireta

$\mathrm{AE}$ - Área do Entorno

AMB - Anuário Mineral Brasileiro

BID - Banco Interamericano de Desenvolvimento

BIRD - Banco Internacional para Reconstrução e Desenvolvimento (Banco Mundial)

CFC's - Cloro- Flúor Carbonos

CNUMAD - Conferência das Nações Unidas para o Meio Ambiente e Desenvolvimento

CONAMA - Conselho Nacional do Meio Ambiente

COEMA - Conselho Estadual do Meio Ambiente

CVRD - Companhia Vale do Rio Doce

CEDERE - Centro de Desenvolvimento Regional

CNEN - Comissão de Energia Nucelar

CIPA - Comissão Interna de Prevenção de Acidentes

CFEM - Compensação Financeira pela Exploração Mineral

DMA - Diretoria de Meio Ambiente

DNPM- Departamento Nacional de Produção Mineral

DST - Doenças Sexualmente Transmissíveis

ECO-92 - Conferência das Nações Unidas sobre o Meio Ambiente e o Desenvolvimento 
EIA - Estudo de Impacto Ambiental

ESALQ - Escola Superior de Agricultura "Luiz de Queiroz"

FCAP - Faculdade de Ciências Agrárias do Pará

FADESP - Fundação de Amparo ao Desenvolvimento do Estado do Pará

FLONACA - Floresta Nacional de Canaã dos Carajás

FNS - Fundação Nacional de Saúde

INPE - Instituto Nacional de Pesquisas Especiais

IBAMA - Instituto Brasileiro de Meio Ambiente e dos Recursos Naturais Renováveis

LI - Licença de Instalação

LO - Licença de Operação

LP - Licença Prévia

MPEG - Museu Paraense Emilio Goeldi

MSS - Mineração Serra do Sossego

NEPA - National Environmental Policy Act

NAEA - Núcleo de Altos Estudos da Amazônia

OAB - Ordem dos Advogados do Brasil

ONGs - Organizações Não-Governamentais

PCA - Plano de Controle Ambiental

PRAD - Plano de Recuperação de Áreas Degradadas

PNMA - Política Nacional do Meio Ambiente

PEA - Programa de Engenharia Ambiental

PDS - Plano de Desenvolvimento Sustentável

RCA - Relatório de Controle Ambiental

RIMA - Relatório de Impacto sobre o Meio Ambiente (Impacto Ambiental)

SECTAM - Secretaria Executiva de Ciência, Tecnologia e Meio Ambiente

SEICOM - Secretaria Executiva de Indústria Comércio e Mineração

SEBRAE - Serviço Brasileiro de Apoio a Pequenas Médias Empresas

SESPA - Secretaria Executiva de Saúde Pública do Estado do Pará

SEMA - Secretaria Estadual de Meio Ambiente

SISNAMA - Sistema Nacional do Meio Ambiente 
SLAP - Sistema de Licenciamento de Atividades Poluidoras

TR - Termo de Referência

USP - Universidade de São Paulo

UFPA - Universidade Federal do Pará

USP - Universidade de São Paulo

UNESCO - Organização das Nações Unidas

OEMA - Organizações estaduais de meio ambiente 


\title{
AVALIAÇÃO DE IMPACTO AMBIENTAL COMO INSTRUMENTO DE POLÍTICAS PÚBLICAS: ANÁlISE DE PROBLEMAS E ESTUDO DE CASO EM ÁREA DE NO ESTADO DO PARÁ
}

\author{
Autora: ANA CLARA SERRÃO FAYAL \\ Orientador : Prof. Dr. ALVARO FERNANDO DE ALMEIDA
}

\section{RESUMO}

A Política Nacional do Meio Ambiente definida pelo governo brasileiro em 1981 criou a "Avaliação de Impactos Ambientais - AIA" e os processos para "Licenciamento de Atividades Efetiva ou Potencialmente Poluidoras". O CONAMA, através da Resolução n. ${ }^{\circ}$ 001/86, definiu o EIA - Estudo de Impactos Ambientais e o RIMA Relatório de Impacto Ambiental, tal como deveriam ser elaborados, para quais atividades seriam obrigatórios e os processos de licenciamentos. Após mais de 20 anos da criação da AIA e mais de 15 anos de efetiva aplicação dos EIA/RIMA, este estudo foi elaborado com o objetivo de analisar as possíveis deficiências estruturais e no funcionamento dos EIA/RIMA, as quais resultam em diversos problemas operacionais na implantação de grandes projetos. Os principais fatores analisados foram o Termo de Referência, as exigüidades de prazos e das verbas para a elaboração dos EIA/RIMA, além de deficiências nos levantamentos em áreas especialmente protegidas e na aplicação da percentagem de Compensação Ambiental. Também são abordados problemas ligados às Audiências Públicas e efetiva comunicação popular dos RIMAs. Este estudo dá um destaque especial nos levantamentos socioeconômicos na Amazônia, 
os quais são considerados como muito superficiais, incompletos, e de capital importância nos grandes projetos, devendo ter perfeita inserção social nos municípios para que busquem sociedades sustentáveis. Na Amazônia, uma das mais ricas regiões do planeta em biodiversidade, as também fantásticas riquezas minerais participam efetivamente entre os precursores do desenvolvimento, o qual se pretende que seja indutor de sociedades sustentáveis. Esta monografia baseou-se em um grande projeto minerário na Amazônia, através de um "Estudo de Caso", onde a AIA, os EIA/RIMA e o Licenciamento Ambiental são analisados em relação aos diversos problemas estruturais apontados com especial atenção na área socioeconômica. Pode-se concluir que a AIA necessita ser aperfeiçoada através dos EIA/RIMA para que os grandes projetos de desenvolvimento na Amazônia possam contribuir para o surgimento de sociedades sustentáveis. 


\title{
EMVIRONMENTAL IMPACT EVALUATION AS PUBLIC POLICY TOOL: PLOBLEMS ANALYSIS AND CASE STUDY IN AN AREA AT PARA STATE
}

\author{
Author: ANA CLARA SERRÃO FAYAL \\ Adviser : Prof. Dr. ALVARO FERNANDO DE ALMEIDA
}

\section{SUMMARY}

The national environmental policy defined by the Brazilian government in 1981 created the "environmental impact evaluation - AIA" and the steps to the license of strength polluted activities. The CONAMA by the resolution $n .001 / 86$, defined the "EIA" - environmental impacts studies and the RIMA - environmental impact report, as they should be elaborated, to which activities they must be done and the licence steps. After more than 20 years of the AIA and more than 15 years of strength application of the EIA/RIMA, this study was done with the goal of analyse the possible structural difficulties and on the working of the EIA/RIMA, which results on several operational problems during the implementation of large projects. The main analysed factors were the Reference Term, the narrow deadline and income to the EIA/RIMA, besides the difficulties on the survey in the protect areas and the application of the environmental compensation percentage. Also, there is an approach on public audience problems and popular communication of the RIMAs. This study stand specially on the socioeconomic survey in Amazonia which are considered as superficial and incomplete, but they are very important on the large projects which must have a perfect social insertion inside the cities in order to get sustainable societies. 
In Amazonia, one of the richest regions of the planet on biodiversity, the mineral riches also have an important participation between the development forerunner, which is intended to be the prompter of sustainable societies.

This monography was based on a large mineral project in Amazonia by a "Case Study" where the AIA, the EIA/RIMA and the environmental license are analysed face to the several structural problems with a special attention on the socioecomic area. We can conclude that the AIA needs to be improved by the EIA/RIMA so that the development of large projects in Amazonia can contribute to the emergence of sustainable societies. 


\section{INTRODUÇÃO}

Estudos sobre alterações ambientais decorrentes de intervenções humanas têm crescido muito no mundo todo, principalmente a partir da Conferência de Estocolmo, em 1972, promovida pela Organização das Nações Unidas - ONU, quando foi apresentado um quadro preocupante em relação à conservação do meio ambiente em nível global. Naquela ocasião, enfatizava-se aquilo que muitos pesquisadores, de vários países, prenunciavam há anos: ou seja o homem estaria deixando, no século XX, sua milenar condição de paciente no processo, tornando capaz de influir significadamente nas transformações do planeta.

O Estudo de Impacto Ambiental (EIA) é um instrumento de caráter técnicocientífico que subsidia uma das etapas da Avaliação de Impacto Ambiental (AIA). Esta etapa, dentro do processo de AIA, é a que possui maior conteúdo técnico-científico e também que consome mais tempo e recursos.

O EIA foi inspirado no direito americano (National Environmental Policy Act NEPA de 1969), tendo sido introduzido no direito positivo, de forma tímida, pela Lei $\mathrm{n}$. 6803 , de 2 de julho de 1980, que "Dispõe sobre as diretrizes básicas para o zoneamento industrial nas áreas criticas de poluição" (Milaré, 1998).

Segundo Milaré (1994), o objetivo central do estudo de impacto ambiental é simples: evitar que um projeto (obra ou atividade), justificável sob o prisma econômico ou em relação aos interesses imediatos de seu proponente, se revele, depois, nefasto ou catastrófico para o meio ambiente. Valoriza-se, na plenitude, a vocação essencialmente preventiva do direito ambiental, expressa na conhecida máxima: é melhor prevenir do que remediar (mieux vaut prevenir que guérir).

$\mathrm{Na}$ década de 80 , a partir da mobilização social a que se assistiu o Brasil, principalmente com o surgimento do movimento ambientalista e final do regime 
autoritário, ganhou o EIA nova função e amplitude com a Lei n. 6 938, de 31 de agosto de 1981, que cuida da "Política Nacional do Meio Ambiente - PNMA, seus fins e mecanismos de formulação e aplicação". Esta tem "como objetivo a preservação, melhoria e recuperação da qualidade ambiental propícia à vida, visando assegurar, no país, condições ao desenvolvimento socioeconômico, aos interesses da segurança nacional e à proteção da dignidade da vida humana". Este foi considerado um marco do ambientalismo brasileiro, porque o EIA é erigido à categoria de instrumento da Política Nacional do Meio Ambiente (Milaré, 1998).

Ainda segundo o autor, o Decreto n. 88351 , de $1^{\circ}$ de junho de 1983, ao regulamentar a Lei n. $6938 / 81$, avançou na matéria, inclusive ampliando o conteúdo da lei regulamentada. Estabeleceu a vinculação da avaliação de impactos ambientais aos sistemas de licenciamentos, outorgando ao Conselho Nacional do Meio Ambiente (CONAMA) competência para "fixar os critérios básicos segundo os quais serão exigidos estudos de impacto ambiental para fins de licenciamentos, com poderes, para tal fim, de baixar as resoluções que entender necessárias".

Hoje esse decreto regulamentar foi substituído pelo Decreto n. 99 274, de 6 de junho de 1990.

A Resolução CONAMA 001/86 no seu artigo $2^{\circ}$ fala da abrangência do EIA, fazendo depender o licenciamento de várias atividades modificadoras do meio ambiente na elaboração de estudo ambiental e respectivo Relatório de Impacto Ambiental (RIMA), que serão submetidos à aprovação do órgão estadual competente e do Instituto Brasileiro do Meio Ambiente e dos Recursos Naturais Renováveis (IBAMA), em caráter supletivo.

As diretrizes gerais e as atividades técnicas a serem desenvolvidas pelo EIA foram previstas nos artigos $5^{\circ}$ e $6^{\circ}$. O artigo $7^{\circ}$ fala de sua realização por equipe multidisciplinar independente do proponente do projeto, enquanto o $8^{\circ}$ mostra à responsabilidade do empreendedor as despesas e custos referentes à realização do estudo (Milaré, 1998).

Os artigos $9^{\circ}, 10^{\circ}, 11^{\circ}$, por seu turno, versam sobre conteúdo e procedimento do Relatório de Impacto Ambiental (RIMA), assim como de sua acessibilidade ao público. 
O EIA, da forma como está previsto na legislação brasileira, pode ser resumido nos seguintes aspectos que, de modo semelhante, refletem modelos vigentes em outros países: i) tem caráter prévio, referindo-se à intenção de implantação, operação e/ou ampliação de um projeto específico a ser desenvolvido em um determinado meio; ii) é multidisciplinar ou, mais adequadamente, interdisciplinar; iii) deve contemplar o meio ambiente nos seus segmentos básicos (meio físico, meio biológico e meio socioeconômico); iv) deve abranger o diagnóstico ambiental da área de influência, análise ou avaliação dos prováveis impactos decorrentes do projeto e as medidas de mitigação e monitoramento associadas aos impactos previstos; v) deve ter suas conclusões traduzidas no documento denominadas Relatório de Impacto Ambiental (RIMA), que o formaliza perante o setor público responsável e o transforma, a princípio, em texto de acesso à opinião pública (Resolução CONAMA 001/86).

Essas características atribuem ao EIA papel de instrumento de planejamento e subsídio fundamental às decisões políticas sobre o projeto.

\subsection{Apresentação}

Na Amazônia, especificamente no Estado do Pará, está se implantando um dos maiores projetos na área extração de cobre de responsabilidade da Mineração Serra do Sossego.

Conforme o que preconiza a Legislação Ambiental e a Resolução 001/86, a Mineração Serra do Sossego S.A (MSS) teve que apresentar à Secretaria Executiva de Ciência Tecnologia e Meio Ambiente do Estado Pará (SECTAM), o Estudo de Impacto Ambiental e o Relatório de Impacto sobre Meio Ambiente (EIA/RIMA), referente ao empreendimento minerário que pretende implantar nos Municípios de Canaã do Carajás e Parauapebas, no sudeste do Estado do Pará.

A MSS propõe a exploração, produção e comercialização de concentrado de minério de cobre, contendo ouro como subproduto. 
A mineração a céu aberto irá ocorrer nos morros do Sossego, Sequeirinho e Serra Dourada, localizados contíguos à Floresta Nacional de Carajás, prevendo-se uma vida útil de pelo menos 15 anos.

O impacto sócio-ambiental previsto no empreendimento do Projeto da Mineração Serra do Sossego, no Município de Canaã dos Carajás, deverá ser muito grande, considerando-se a debilidade de sua estrutura produtiva e de gestão. Convém, entretanto, considerar que a população do município deverá passar por um período de forte crescimento, sendo de se esperar uma significativa modificação em seu perfil demográfico e funcional. Prevê-se considerável crescimento urbano e maior pressão de por serviços públicos, sobre uma oferta em que apenas $12 \%$ da população atual tem acesso à energia elétrica e onde ainda não existe um sistema de abastecimento de água.

Deverá ocorrer um aumento das populações num nível acima da capacidade de absorção da infra-estrutura existente no município. Haverá, possivelmente, um fluxo de pessoas para o Município de Canaã dos Carajás em busca de empregos e também com intuito de prestação de serviços de todas as espécies.

Em decorrência do aumento do fluxo de pessoas, acredita-se no surgimento de alguns problemas de saúde pública, sendo possível á ocorrência de alguns tipos de epidemias, ou ampliação de algumas endemias existentes ou mesmo o aumento da propagação de doenças sexualmente transmissíveis.

Deve-se levar em conta que são projetos de grandes proporções, com impactos de difícil mitigação e compensação, para os quais na economia globalizada e altamente competitiva da atualidade, torna-se imperativa a necessidade de inovações.

A MSS adotou providências orientadas para a solução dos impactos negativos sobre a economia, a sociedade e o meio ambiente, recomendados pelos órgãos ambientais, à luz do Estudo de Impacto Ambiental.

Além dessas exigências, a MSS está concebendo uma série de medidas ambientais, tecnológicas, econômicas, sócio-culturais e político-institucionais, destinadas a promover e garantir o desenvolvimento sustentável de Canaã dos Carajás. Tais atividades constituem o centro da estratégia concebida e a ser posta em prática com o Sistema de Gestão Ambiental e o Plano de Desenvolvimento Sustentável do Município 
de Canaã dos Carajás que, segundo a empresa será um dos principais agentes do desenvolvimento daquele município.

O programa de trabalho da MSS, acima mencionado traz as diretrizes do que será o Plano de Desenvolvimento Sustentável (PDS), que tem o objetivo de minimizar os impactos sócio-ambientais, constituindo-se em instrumento de identificação de atividades econômicas passíveis de execução sustentada, em termos ambientais, socioeconômicos e político-institucionais no município, objeto de ação do plano.

O PDS terá o seu próprio Sistema de Gestão (SG), que compreenderá o ordenamento do processo de gestão dos negócios implementáveis na área objeto do Plano, o qual terá uma interface com as ações dos Programas de Controle Ambiental e com o Sistema de Gestão Ambiental do projeto.

Neste trabalho, o EIA/RIMA da MSS será tomado como exemplo de um grande projeto na Amazônia.

\subsection{Justificativa}

O EIA é um sistema recente, introduzido há apenas duas décadas e por isso, ele é considerado por alguns autores, como ainda pouco aperfeiçoado. O Relatório de Impacto Ambiental (RIMA) surgiu como decorrência da Lei Federal $n^{\circ} 6.938$ de 1981, que instituiu a Política Nacional do Meio Ambiente (PNMA) ou seja, os parâmetros para a legislação ambiental em âmbito federal.

A Lei $n^{\circ}$ 6.938/81 disciplinou o licenciamento não apenas de atividades potencialmente poluidoras mas de qualquer atividade modificadora do meio ambiente, físico e social.

O Conselho Nacional do Meio Ambiente (CONAMA), regulamentando a Lei 6.938/81, acrescentou mais exigências àquelas anteriormente solicitadas em nível estadual ou municipal. Ela condicionou o licenciamento de algumas atividades mais impactantes à apresentação de um Estudo de Impacto Ambiental (EIA) e ao resumo de suas conclusões, em linguagem simplificada, através de um Relatório de Impacto Ambiental (RIMA) de acesso público. 
Neste trabalho serão analisados alguns dos problemas que hoje existem na realização de um EIA, visando o seu aperfeiçoamento. Para tanto, efetuou-se uma pesquisa com especialistas de notório saber na área de impacto ambiental, através do envio de questionário via on-line, com objetivo de caracterizar estes problemas.

Os problemas apontados também estão baseados na literatura e nas observações feitas em diversos EIA/RIMA analisados na SECTAM durante os 9 anos de atuação da autora neste órgão público.

A experiência do Orientador contribuiu nas definições do "estado da arte" e deficiências dos EIA/RIMA.

Com seria praticamente impossível à análise detalhada de diversos EIA/RIMA, principalmente pela quantidade de dados e tempo disponivel, escolheu-se um EIA/RIMA atual, de um grande empreendimento na Amazônia como modelo: o projeto da Mineração Serra do Sossego no Estado do Pará, dando-se ênfase nos aspectos socioeconômicos.

\subsection{Problemas}

O Estudo de Impacto Ambiental e o Relatório de Impacto Ambiental (EIA/RIMA), são instrumentos de licenciamento ambiental que podem apresentar diversas falhas estruturais, dificultando a implementação do empreendimento. Essas falhas estão listadas a seguir:

\subsubsection{Termo de referência}

Os problemas muitas vezes ocorrem logo no início do processo, com a apresentação do Termo de Referência ao empreendedor, pelo órgão ambiental. Em muitos casos, eles são extremamente genéricos e necessitariam ser mais objetivos para atender às diretrizes propostas pela Resolução Conama $n^{\circ}$ 001/1986 do CONAMA. Trata-se da preparação de Termos de Referência ou instruções técnicas especificas a cada projeto e suas áreas de influência, de modo que o estudo forneça objetivamente as informações a respeito dos impactos mais importantes do projeto e sobre os fatores 
ambientais mais relevantes, aqueles que afetam os recursos ambientais de interesse da comunidade.

O Termo de Referência é o instrumento orientador para a elaboração de qualquer tipo de Estudo de Impacto Ambiental.

Tem por objetivo estabelecer as diretrizes orientadoras, conteúdo e abrangência do estudo exigido do empreendedor, em etapa antecedente à implantação da atividade modificadora do meio ambiente.

É elaborado pelo órgão de meio ambiente a partir das informações prestadas pelo empreendedor na fase de pedido de licenciamento.

O Termo de Referência bem elaborado é um dos passos fundamentais para que um estudo de impacto ambiental alcance a qualidade esperada.

Por outro lado, o Termo de Referência não acompanha o EIA, não sendo disponível à sociedade.

\subsubsection{Custos de elaboração do EIA}

Outro fator que prejudica a elaboração do Estudo de Impacto Ambiental são as verbas destinadas a custeá-lo. Nas empresas públicas, as firmas de consultoria concorrem a licitações nas quais o critério é o menor preço dos serviços. Tal fato significa a entrega do estudo, na maioria das vezes, não ao concorrente mais qualificado, mas àquele que apresentou o menor custo, eventualmente subestimando seu detalhamento ou sua profundidade. Possivelmente, as qualidades do Estudo e do Relatório de Impacto Ambiental podem refletir a falta de critério adotada no julgamento da concorrência.

Em geral, os cronogramas e orçamentos restritos dos empreendedores, podem impedir a coleta de dados primários que poderiam suprir as deficiências de informação das entidades de meio ambiente e demais instituições de governo.

Os custos do EIA/RIMA deve ser de pelo menos 1\% (um por cento) do investimento do empreendimento, segundo o que prescreve o Decreto 95.733, de 12.02.1988, que determina em seu art. $1^{\circ}$ : "No planejamento de projetos e obras, de 
médio e grande porte, executados total ou parcialmente com recursos federais, serão considerados os efeitos de caráter ambiental, cultural e social, que esses empreendimentos possam causar ao meio considerado", e no parágrafo único deste mesmo artigo: "identificados efeitos negativos de natureza ambiental; cultural e social, os órgãos e entidades federais incluirão no orçamento de cada projeto ou obra, dotações correspondentes, no mínimo, a $1 \%$ (um por cento) do mesmo orçamento destinado à prevenção ou correção desses efeitos.”, estes deveriam ser informados à sociedade, com a finalidade de se fazer uma correlação entre o valor do empreendimento e valor do estudo.

\subsubsection{Prazo para execução do EIA}

Em geral os prazos para elaboração dos estudos de impacto ambiental, são muito reduzidos em virtude da necessidade premente de licenciamento, bem como para redução de custos.

\subsubsection{Sazonalidade}

Os projetos de grande porte, principalmente nos ambientes onde ocorrem grandes variações sazonais necessitam de levantamentos no inverno e verão, caso contrário deixam de observar as variações em função da sazonalidade. Tal fato ocorre principalmente no Meio Biológico.

\subsubsection{Unidades de conservação e reservas indígenas}

Quando ocorrem Unidades de Conservação ou Reservas Indígenas na área de influência direta de um empreendimento os dados para elaboração do EIA/RIMA devem ser particularizado, para as Unidades de Conservação, conforme o que prescreve a Lei 9.985, de 18 de julho de 2000, que institui o Sistema Nacional de Unidades de Conservação da Natureza - SNUC. Ações impactantes em Reservas Indígenas devem ter a aprovação do Congresso Nacional, de acordo com os Decreto N..$^{\circ} 24$, de 4 de fevereiro de 1999 e Decreto N. ${ }^{\circ} 1.141$, de 19 de Maio de 1994. 


\subsubsection{Participação da sociedade civil em audiências públicas}

A participação do público deve ser organizada, de modo que ele tenha amplo conhecimento do projeto, que possa decidir sobre o que é melhor para as comunidades afetadas pelo empreendimento. As comunidades normalmente não possuem conhecimento técnico para discutir sobre os impactos oriundos da implantação do projeto. Seria necessário ter reuniões preparatórias para as audiências públicas, juntamente com os atores envolvidos no processo.

Outro ponto importante que dificulta a participação da sociedade civil, é a utilização de linguagem técnica no Relatório de Controle Ambiental - Rima, o qual deveria ser um documento que facilitasse a compreensão à cerca do empreendimento.

\subsubsection{Compensação ambiental relativa à implantação de grandes projetos}

Os Estudos de Impacto Ambiental devem apresentar uma proposta de aplicação em Unidade de Conservação de no mínimo $0,5 \%$ do total do investimento do projeto, preconizado na Resolução 002/96 CONAMA, como forma compensatória aos danos ambientais decorrentes da implantação do empreendimento. O que ocorre em algumas vezes, o órgão ambiental não aplica o recurso em áreas próximas ao projeto.

\subsubsection{Levantamento socioeconômico para estudo de impacto ambiental}

Observa-se freqüentemente uma fragilidade nos levantamentos socioeconômicos nos estudos de impacto ambiental, muitas vezes decorrente em função da redução de custos, outras do tempo para realização dos levantamentos necessários para execução do trabalho em campo.

Um outro fator importante refere-se a formulações das propostas no aspecto socioeconômico de inserção social do projeto nas comunidades afetadas pelo empreendimento. 
1.3.9 Acompanhamento da execução das medidas mitigadoras, da verificação do cumprimento das exigências das licenças, dos programas de monitoramento e dos programas de recuperação.

Alguns dos fatores primordiais são as dificuldades de acompanhamento das medidas mitigadoras que serão implantadas após a emissão das licenças pelo órgão ambiental estadual, muitas vezes em decorrência da falta de recursos financeiros e do reduzido número de técnicos existente no órgão ambiental, principalmente levando-se em consideração o tamanho do Estado do Pará.

\subsubsection{Conflito de competências quanto ao licenciamento ambiental}

Muitos problemas estão ocorrendo entre o IBAMA e a Órgão Ambiental do Estado do Pará, em virtude do licenciamento ambiental de grandes projetos na Amazônia.

Existem outros fatores que interferem na eficiência do Estudo de Impacto Ambiental, mas que não fazem parte das falhas estruturais de um estudo, tais como segue.

\subsubsection{Coordenação e formação da equipe multidisciplinar}

Uma questão básica na realização de um EIA é organização da equipe multidisciplinar. Entretanto, mais importante ainda, é a indicação adequada de seu coordenador. Uma coordenação fraca apenas distribuirá e administrará os trabalhos, enquanto que uma efetiva coordenação levará à troca de informações, à estruturação das idéias, ao encadeamento de atividades e ao consenso sobre as questões básicas em discussão.

\subsubsection{Ausência de um banco de dados nos órgãos ambientais}

Outro ponto é a questão da carência de dados e informações que sirvam de base aos estudos de impacto ambiental. Essa questão diz respeito, em parte, à falta de estrutura e recursos dos órgãos ambientais, na medida em que lhes cabe o 
monitoramento da qualidade do meio ambiente, ao menos para os fatores tradicionalmente ligados às suas áreas específicas de controle: o ar, a água, os ecossistemas naturais, de acordo com que está previsto na Lei da Política Nacional Meio Ambiente desde de 1981 a implantação Sistema Nacional de Informações Ambientais (SISNIMA), nos órgãos ambientais.

\subsubsection{Remuneração salarial, capacitação dos técnicos junto aos órgãos ambientais e avaliação do EIA/RIMA (equipes externas de consultoria)}

Normalmente, a crise econômica é responsabilizada por grande parte dos problemas em questão e principalmente pelas remunerações insatisfatórias de seus servidores. A remuneração não adequada de servidores acaba gerando um outro problema que é a diminuição da qualificação técnica. Por outro lado, o desempenho de algumas equipes técnicas tem sido insatisfatório, podendo esse resultado estar associado à falta de conhecimentos técnico-científicos dos profissionais envolvidos no estudo. Outro fator é a não contratação de equipes externas de consultoria ambiental que pudesse auxiliar os técnicos na análise dos estudos.

\subsubsection{Relacionamentos entre empreendedor, órgão ambiental e entidades de meio ambiente}

Os relacionamentos entre as entidades de meio ambiente, os órgãos governamentais e as empresas necessitam ser aprimorados, pois é importante o entendimento entre eles para que o processo de AIA apresente avanços significativos.

\subsubsection{Carência de empresas habilitadas}

A carência de empresas habilitadas na elaboração de Estudo de Impacto Ambiental, tem levado estudos a reprovação pelos órgãos ambientais dos Estados. 


\subsubsection{Divulgação e acesso às informações dos estudos de impacto ambiental}

A ausência de divulgação dos relatórios do EIA, é um aspecto muito grave para a transparência do processo de licenciamento do empreendimento. Os EIA deveriam ser distribuídos a grandes bibliotecas e ser de fácil acesso e isso deveria ser bem divulgado, por exemplo, pelos jornais. As decisões finais devem ser divulgadas rotineiramente em Diário Oficial e, também, em revistas científicas de ampla divulgação. Os órgãos de controle ambiental deveriam ter publicações que periodicamente divulgassem as decisões sobre os projetos analisados, legislação, etc. Outra questão importante, é que não pode haver segredo num EIA; todas informações necessárias devem ser incluídas. Ainda que devam ser preservados as patentes e os direitos sobre processos tecnológicos industriais, etc, nunca poderão ser sonegadas informações pelo proponente que permitam conhecer, por exemplo, suas fontes de emissão de poluentes.

\subsection{Hipótese de trabalho}

Os EIA/RIMA como documento de licenciamento de grandes projetos na Amazônia, decorrente da Avaliação de Impacto Ambiental, apresentam diversas deficiências estruturais e devem ser aperfeiçoados para que desenvolvam seus objetivos preferencialmente direcionados para sociedades sustentáveis e para a busca de uma melhor qualidade de vida.

\subsection{Objetivo geral}

Analisar as possíveis deficiências estruturais e de funcionamento do instrumento legal de implementação da AIA, tendo como objeto o Estudo de Impacto Ambiental e o Relatório de Impacto Ambiental para efeito de licenciamento de empreendimentos de grande porte no Pará.

Estas análises serão efetuadas através de um Estudo de Caso do EIA/RIMA da Mineração Serra do Sossego no Estado do Pará, com ênfase nos aspectos socioeconômicos. 


\subsection{Objetivos específicos}

a) levantar as deficiências e dificuldades de implementação do estudo de impacto ambiental;

b) identificar e discutir os fatores que levam às limitações ou falhas no EIA/RIMA e nos planos de controle ambiental, no meio socioeconômico;

c) identificar possíveis falhas e comprometimentos no processo de licenciamento ambiental estadual;

d) contribuir para a produção de conhecimentos no campo de Avaliação de Impactos Ambientais. 


\section{REVISÃO DE LITERATURA}

\subsection{Avaliação de impacto ambiental (AIA)}

A Avaliação de Impacto Ambiental surgiu em 1969, nos Estados Unidos, quando o seu Congresso aprovou a National Environmental Policy Act (NEPA), em resposta a pressões de entidades ambientalistas. Corresponde à lei da Política Nacional de Meio Ambiente daquele país. A NEPA institui, como diretriz para as agências federais, a execução de AIA interdisciplinar no planejamento e decisão de planos, programas, projetos e de propostas legislativas de intervenção sobre o meio ambiente.

Nos países em desenvolvimento, a AIA foi introduzida na década de 70, após a reunião do Clube de Roma e da Conferência Internacional das Nações Unidas (Estocolmo, 1972), muitos esforços vêm sendo desenvolvidos na esfera do setor do ambiente no sentido de estabelecer uma base metodológica para o desenvolvimento de estudos ambientais. Nessa ocasião, os países em desenvolvimento concluíram que AIA seria um risco às suas autonomias política e econômica, além de considerarem a AIA um luxo dos países desenvolvidos (Bursztyn, 1994).

Passados mais de dez anos do seu surgimento nos Estados Unidos, a AIA começou a ser introduzida no Brasil no início dos anos oitenta. Embora precedida por outros dispositivos legais de menor alcance territorial ou temático e por algumas experiências pioneiras realizadas por exigências de órgãos internacionais de financiamento de projetos de desenvolvimento, como exemplo a barragem e usina hidrelétrica de Sobradinho em 1972, segundo Moreira (1989).

A Política Nacional do Meio Ambiente, Lei Federal no 6 938, de 31 de agosto de 1981, é reconhecida como o principal marco na introdução de AIA no Brasil. Sua promulgação culminou com um processo de evolução da legislação brasileira de proteção ao meio ambiente, que se iniciou com os dispositivos de proteção aos recursos 
naturais, nos anos trinta; evoluiu nos anos setenta para o controle da poluição, cujo imperativo se fez sentir com o agravamento dos problemas ambientais decorrentes da rápida industrialização e urbanização do País; incorporou, no início dos anos oitenta, os conceitos de planejamento territorial, com as leis de proteção aos mananciais e zoneamento urbanos, entre outras.

De acordo com Dias (2001), nos termos da Lei da Política Nacional do Meio Ambiente, a AIA aportou no Brasil sem qualquer limitação ou condicionante, podendo alcançar projetos públicos ou privados, urbanos ou rurais, industriais ou não. Do mesmo modo, sua aplicação não está restrita a obras e atividades, podendo atingir níveis mais elevados de decisão como políticas, planos e programas. Posteriormente à promulgação desta lei, no entanto, os dispositivos que a regulamentam - Decreto $\mathrm{n}^{\circ} 88.351 / 1983$, Decreto $n^{\circ}$ 99.274/1990 e Resolução Conama $n^{0}$ 01/1986 - estabeleceram um vínculo entre a AIA e o licenciamento ambiental, subordinando aquela a este. Com isso, restringiram o alcance deste instrumento de política ambiental e deixaram de incluir as políticas, planos e programas em seu âmbito de aplicação.

Os Países da América Latina que incorporaram a Avaliação de Impacto Ambiental foram: Colômbia, Venezuela, México, Argentina, Paraguai, Uruguai e Brasil.

Segundo Monosowski (1993), é necessário discutir avaliação de impacto ambiental com o conceito de desenvolvimento sustentável, visto que, após 1972, ocorreu uma nítida evolução do referido conceito. A idéia de que os recursos eram finitos e que alguma política era necessária para sua utilização vem de Malthus, mas a idéia de sustentabilidade propriamente dita foi fundamentalmente desenvolvida pelos grupos ambientalistas dos anos 80. Um marco na noção da sustentabilidade foi o conceito de ecodesenvolvimento surgido do debate de Estocolmo e que coloca três elementos: o da sustentabilidade ecológica, o da viabilidade econômica e o da sustentabilidade política, ou seja um desenvolvimento ecologicamente prudente, economicamente viável e socialmente justo.

Em 1987 é expressa a evolução do conceito através do Relatório Brundtland, sendo este um conceito vinculado à questão do bem estar social e individual, e se justifica pela complexidade dos problemas ambientais e pela mudança de sua escala. No início da 
década de 90 ocorreu uma mudança no debate da questão ambiental para um foco maior nos problemas globais como a redução da camada de ozônio, as mudanças climáticas, as questões da biodiversidade, que foram debatidas na Conferência das Nações Unidas sobre o Meio Ambiente e Desenvolvimento, ECO 92.

Sánchez (1999) ${ }^{1}$ destaca, ainda, como grande impulso para a difusão internacional da AIA, sua discussão na Conferência das Nações Unidas sobre o Meio Ambiente e Desenvolvimento (CNUMAD), a Rio 92, e a inclusão da Declaração do Rio do princípio: "A avaliação do impacto ambiental, como um instrumento nacional, deve ser empreendida para atividades propostas que tenham probabilidade de causar um impacto adverso significativo no ambiente e sujeitas a uma decisão da autoridade nacional competente."

Monosowski (1993), lembra no que se refere à avaliação de impacto ambiental, que muito se discutiu sobre o que seria e quais os requisitos para a realização de um estudo de impacto ambiental adequado. Pondera-se muito sobre as dificuldades de adaptação desse instrumento às condições dos países em desenvolvimento. Alguns dos temas constantes nos debates dos últimos anos têm sido: 1) a disponibilidade de dados confiáveis para avaliação; 2) o desenvolvimento das capacidades técnicas e metodológicas de análise e interpretação; 3) a adequação das metodologias e critérios de avaliação a uma realidade tanto científica como política dos paises em desenvolvimento; 4) a adaptação dos procedimentos de avaliação às condições políticas e institucionais específicas de cada país ou região; 5) o papel desse estudos na gestão ambiental.

No Brasil, a adoção da AIA decorreu, principalmente, de uma resposta do Estado Nacional às exigências ambientais dos organismos multilaterais de financiamento (BID e BIRD), em função da repercussão internacional dos impactos ambientais desencadeados pelos grandes projetos de desenvolvimento implementados nas décadas de 80, principalmente na Amazônia.

Sánchez, L.E. Avaliação de impacto ambiental. São Paulo: PECE, 1999./Notas de aula da disciplina, Al002- Avaliação de Impacto Ambiental. 1v. 
Anteriormente à aprovação da Lei 6 938/81, o sistema normativo brasileiro já exigia, pela Lei Nº $6803 / 1980$, avaliações de impacto ambiental, denominados "estudos especiais de alternativas e de avaliação de impactos", para alguns empreendimentos poluidores, tais como: pólos petroquímicos, cloroquímicos, carboquímicos e instalações nucleares.

De acordo com o texto legal, a aplicabilidade da AIA na condição de instrumento de gestão ambiental é favorecida, durante o seu processo de execução, pelo relacionamento com outros instrumentos normativos de controle de padrão da qualidade ambiental, das normas de licenciamento e das penalidades legais.

A Sistemática da AIA, instrumento instituído pela Lei Federal 6 938/1981, foi regulamentada pela Resolução 001/1986 do Conselho Nacional de Meio Ambiente (CONAMA) a qual estabelece as definições, as responsabilidades, os critérios básicos e as diretrizes gerais para uso e implementação da Avaliação de Impacto Ambiental como um dos instrumentos da Política Nacional de Meio Ambiente. Esta Lei estabelece a Política Nacional de Meio Ambiente e firma o Sistema Nacional de Meio Ambiente (SISNAMA) como órgão executor. Dentre as importantes inovações em nível institucional que introduz, destacam-se: 1. A criação do CONAMA, órgão consultivo e deliberativo, diretamente vinculado ao Presidente da República e encarregado de assessorar, estudar e propor diretrizes de políticas ambientais, assim como normas e padrões de controle ambiental; 2. A criação do SISNAMA, que inclui o conjunto das instituições governamentais que se ocupam da proteção e da gestão da qualidade ambiental, em nível federal, estadual e municipal, e também os órgãos da Administração Pública Federal, cujas atividades afetem diretamente o meio ambiente. O Conama constitui a instância superior do Sisnama.

A Lei Federal $n^{\circ} 6938 / 1981$ foi regulamentada pelo Decreto Federal $n^{\circ} 88351$, de 01.06.1983. Este decreto instituiu os tipos de licenciamentos aplicados no Brasil e especifica as atribuições do CONAMA.

É interessante ressaltar que a Lei no 6 938/1981 não vinculou a avaliação de impacto ambiental ao licenciamento, possibilitando sua realização não apenas no caso de obras ou atividades sujeitas ao licenciamento ambiental, como também políticas, planos 
e programas. Este vínculo, surge em sua regulamentação, primeiramente pelo Decreto ${ }^{\circ}$ 88. 351/1983 (substituído pelo Decreto $n^{\circ}$ 99.274/1990) e posteriormente na Resolução Conama $\mathrm{n}^{\circ} 01$, de 23 de janeiro de 1986, que disciplinou a matéria. Na prática, estes dispositivos terminaram por restringir o instrumento de política ambiental formulada na Lei $n^{\circ} 6$ 938/1981, subordinando-o ao licenciamento e excluindo, desta maneira, sua aplicação a políticas, planos e programas (Gouvêa, 1998).

O licenciamento ambiental foi instituído no Brasil, no plano federal, pela Lei da Política Nacional do Meio Ambiente e estruturado na forma de três tipos de Licenças. Estas são denominadas:

a) A Licença Prévia constitui a primeira fase do licenciamento ambiental. Esta deve ser requerida na etapa preliminar de planejamento do empreendimento e ou atividade. A licença será concedida mediante a análise da localização e concepção do empreendimento; a apreciação dos requisitos básicos a serem atendidos nas próximas fases e a observância dos planos municipais, estaduais ou federais para a área de abrangência do empreendimento e/ou atividade. A outorga da LP é o "sinal verde" para o detalhamento dos projetos, incluídos os dispositivos de proteção do meio ambiente. É nesta fase do licenciamento que o Estudo de Impacto Ambiental deve ser apreciado, como condição para a expedição da LP;

b) A Licença de Instalação, que corresponde a segunda fase do licenciamento ambiental, é concedida mediante a análise e aprovação dos projetos executivos de controle de poluição. Esta licença permite a instalação e, ou, ampliação de um empreendimento. $\mathrm{O}$ que permitirá a implantação do canteiro de obras, movimentação de terra, construção de vias, edificação de infra-estruturas e instalações de equipamentos, fixando as condições para a obtenção da Licença de Operação.

c) Licença de Operação a qual autoriza a operação do empreendimento e/ou a realização da atividade impactante. Isto se da após a verificação do efetivo cumprimento do que consta as Licenças Prévias e de Instalação.

Embora a fase de obtenção da Licença Prévia seja o momento natural para a realização do EIA, posto que seu objetivo é influir no mérito da decisão administrativa, 
(Milaré \& Benjamin, 1993) sustentam que o estudo pode ser exigido a qualquer tempo, desde que se possa remediar uma situação crítica ao meio ambiente.

Os procedimentos para a concessão das licenças ambientais e sua interação com os procedimentos de avaliação de impacto ambiental foram objeto de resoluções do Conama para atividades específicas. É o caso da citada Resolução Conama nº 06/1987, que trata do licenciamento ambiental de obras de grande porte, especialmente aquelas destinadas à geração de energia elétrica e inclui o Relatório de Impacto Ambiental (Rima) entre os requisitos para obtenção da Licença Prévia. As Resoluções Conama $\mathbf{n}^{\circ} 9$ e 10, de dezembro de 1990, que disciplinam o licenciamento ambiental das atividades de extração mineral, relacionam o EIA e o Rima entre os documentos de instrução do requerimento da Licença Prévia.

Conforme ressaltado acima o Decreto Federal $n^{\circ} 88$ 351, de 01.06.1983, institui o CONAMA e define suas atribuições. Estas, basicamente, objetivam o estabelecimento de definições, responsabilidades, critérios básicos e diretrizes gerais para uso e implementação da Política Nacional de Meio Ambiente. Desta forma, no uso de suas atribuições o CONAMA tem processado diversas regulamentações por meio de resoluções.

Dentre essas, as Resoluções CONAMA 001, de 23.01.1986 e 237, de 19.12.1997, estabelecem definições, responsabilidades critérios básicos e diretrizes gerais para uso e implementação da Avaliação e Estudos de Impactos Ambientais (Silva, 2002).

Para dar o suporte teórico-conceitual aos estudos de AIA revisou-se alguns conceitos chaves com a intenção de aprender o significado das mudanças sociais, entendidas como impactos ambientais advindos das transformações dinâmicas das relações entre a natureza e sociedade. Estabeleceu-se o desafio de tratar os impactos ambientais sob o ponto de vista multi e interdisciplinar.

Os primeiros paises a aderir ao sistema introduzido pelos Estados Unidos, da avaliação de impacto ambiental previamente às decisões governamentais importantes, foram o Canadá, a Nova Zelândia e a Austrália, ainda no início dos anos 70. Sánchez (1999), destaca como razões para esta rápida adesão o fato de estes países terem sido colônias britânicas e, como tal, haverem tido um modelo de desenvolvimento 
semelhante entre si, além de herdarem um sistema jurídico e político semelhante. Conseqüentemente, além de apresentarem problemas ambientais similares em natureza e extensão, a adaptação ao sistema era mais imediata.

Outros, como a Grã-Bretanha, a República Federal Alemã e os países escandinavos, adaptaram a legislação existente e os processos de planejamento aos princípios da AIA, utilizando-os caso a caso, não havendo porém exigências formais quanto à aprovação dos estudos ou vínculos legais à tomada de decisão (Kennedy, 1987). De todo modo, a cultura legal e administrativa de cada um desses países, por diferir substancialmente da americana, fez surgir experiências bastante variadas, muitas das quais lograram aprimorar o modelo original. Contudo, os trabalhos de apreciação e crítica da efetividade das diversas formas de adoção da AIA concluem que a instituição legal do processo é fundamental para que se alcancem os objetivos de proteção do meio ambiente, o que, juntamente com a vontade política e o compromisso de todos os setores envolvidos, pode garantir bons resultados (Moreira, 1989).

A avaliação de impacto ambiental, como instrumento de decisão na aprovação de projetos, atividades e mesmo políticas, leis, planos e programas, encontra-se hoje disseminada amplamente em todo o mundo, seja inserida no sistema de proteção do meio ambiente de muitos paises (mais de uma centena), na forma de leis ou procedimentos administrativos, seja pela atuação de organismos internacionais, dos quais depende a maioria dos grandes projetos de infra-estrutura dos países em desenvolvimento. Considerados os procedimentos de âmbito estadual (ou provincial), o número total de jurisdições em todo o mundo que adotam o processo de AIA é estimado em cerca de 2000 (Sadler, 1996).

Uma questão importante é discutir a diversidade dos conceitos de impacto ambiental, como também o de poluição é, basicamente, um conceito antropocêntrico. Ele está calcado nos efeitos das ações humanas sobre os ecossistemas e envolve, também, os efeitos das mesmas sobre a própria sociedade humana e sobre a sua economia.

Em revisão feita por Sánchez (1998), o autor apresenta uma coleção de definições, apontadas a seguir, nas quais se destacam como atributos essenciais da AIA seu caráter 
prévio, seu vínculo com o processo decisório e a necessidade de envolvimento do público no processo.

a) Munn (1979): Atividade que visa identificar, prever, interpretar e comunicar informações sobre as conseqüências de uma determinada ação sobre a saúde e o bem-estar humanos. (Ação é definida como qualquer projeto de engenharia, proposição legislativa, política, programa ou procedimento operacional);

b) Jain et al. (1977): um estudo das mudanças prováveis nas várias características socioeconômicas e biofísicas do meio ambiente que podem resultar de uma ação proposta ou iminente;

c) Moreira (1992): Instrumento de política ambiental, formado por um conjunto de procedimentos capaz de assegurar, desde o início do processo, que se faça um exame sistemático dos impactos ambientais de uma ação proposta (projeto, programa, plano ou política) e de suas alternativas, e que os resultados sejam apresentados de forma adequada ao público e os responsáveis pela tomada de decisão, e por eles sejam considerados. Além disso, os procedimentos devem garantir a adoção das medidas de proteção ao meio ambiente determinadas, no caso de decisão sobre implantação do projeto;

d) Iaia (1996): Processo de identificar, prever, avaliar e mitigar os efeitos relevantes de ordem biofísica, social ou outros de projetos ou atividades antes que decisões importantes sejam tomadas;

e) Glasson et al. (1994): Um processo sistemático que examina antecipadamente as consequêencias ambientais de ações humanas.

A avaliação de impacto ambiental não é conhecida apenas por incrementar os conhecimentos acerca das relações entre determinadas atividades humanas e o meio ambiente natural ou construído. A AIA objetiva, fundamentalmente, subsidiar decisões. Embora seja este o papel mais tradicionalmente atribuido à AIA, não é o único. Respondendo à questão Para que serve a AIA?, Sánchez (1993) identifica quatro papéis complementares que este instrumento pode desempenhar: (1) ajuda à decisão, (2) ajuda à concepção de projetos, (3) instrumento de gestão ambiental e (4) instrumento de negociação social. 
No papel de ajuda à decisão, a Lei de Política Nacional de Meio Ambiente, que introduziu a AIA a nível nacional, não estabelece nenhuma relação formal deste instrumento com o licenciamento, no Brasil esta relação não é muita clara. A tomada de decisão pode dar-se no âmbito de órgãos de governo, ao licenciar ou autorizar uma atividade; de organismos de financiamento, ao conceder empréstimos ou fundos para a execução de projetos e obras; ou empresas, na escolha da melhor alternativa para o direcionamento de suas atividades, de acordo com Sánchez (1993).

Ainda segundo o autor como instrumento de gestão ambiental, á aplicação dos procedimentos de AIA produz os elementos fundamentais para a concepção de um sistema de gestão ambiental que, uma vez implantado, servirá para garantir a implementação das medidas de proteção ao meio ambiente estabelecidas no processo e avaliar o acerto das previsões, tanto dos impactos ambientais, como da eficiência das medidas propostas para sua atenuação.

Para administração pública, gestão é um ato de gerir, gerenciar e administrar. Neste sentido, a gestão ambiental representaria uma administração de tudo que envolve todos os seres da natureza física e a natureza humana e representa, também, uma negociação de decisões e ações (Coelho, 1999). O envolvimento de diferentes espécies (animais e plantas) que se sustentam do solo, da água e do ar, promovendo diferentes ciclo ecológicos e de vida, o desenvolvimento das mais diferentes atividades humanas de extração, produção, consumo dos recursos naturais, a disposição dos resíduos sólidos, efluentes líquidos e emissões atmosféricas, tornam o meio ambiente dos diversos locais em sistemas extremamente complexos e sensíveis, dotados de tantas especificidades que fazem da gestão ambiental uma tarefa nada fácil de realizar.

Num sentido mais próximo do campo da ciência política, um número de autores (Machado, 1995 \& Pires, 1997) observaram que a gestão ambiental vem sendo entendida como um processo de articulação negociada das decisões e ações do Estado, das empresas e dos diferentes agentes sociais que interagem numa dada área geográfica com vistas a garantir adequação dos meios de exploração dos recursos ambientais às especificidades do meio ambiente, respeitando princípios e diretrizes previamente acordados e/ou definidos. Em outras palavras, conforme vem sendo discutido, gestão 
ambiental tem tido por objetivos promover, de forma coordenada e democrática, o reordenamento das atividades controle sobre o uso dos recursos ambientais e proteção ambiental.

A gestão ambiental envolve todos esses aspectos e algo mais. Envolve a planejamento, que indica o que será controlado. Envolve o controle dos indicadores fornecidos que serão elementos para avaliação e para outra etapa do planejamento. Essa é a face administrativa da gestão ambiental. $\mathrm{O}$ algo mais é sua face política. Essa face política diz respeito à descentralização de decisões e/ou ações. Ela é por definição uma negociação entre Estado e atores sociais diversos.

Sánchez (1993) aborda que finalmente, o papel da AIA como instrumento de negociação entre atores sociais: se por um lado o instrumento AlA fornece a base informacional da negociação, o procedimento de AIA estabelece as condições em que esta pode se dar (audiências públicas, obrigatoriedade de medidas compensatórias etc.).

A participação do público, que pode atingir diferentes níveis de envolvimento, dependendo de organização, políticas de governo e mesmo de políticas empresariais, é capaz de revelar a percepção que ele tem do projeto e de seus impactos ambientais, que nem sempre coincide com a dos especialistas, permitindo administrar, antecipadamente e com maior eficácia, futuros conflitos com a sociedade.

Com diferentes formulações nas muitas jurisdições onde é empregada, a AIA engloba sempre um conjunto articulado de atividades e procedimentos ao qual se denomina processo de avaliação de impacto ambiental.

A literatura é rica em modelos que buscam representar o processo de AIA em suas muitas versões. Sánchez (1998), elaborou o diagrama apresentado na (Figura 1) que contém os pontos comuns e mais freqüentemente presentes neste processo. Nem todas as etapas representadas na figura estão presentes em todas as jurisdições e o modo como são desenvolvidas, assim como sua importância no processo, varia consideravelmente. As etapas podem ser agrupadas em três grandes blocos que correspondem a: (1) etapas iniciais, quando se procede à avaliação inicial, definindo-se o tipo de estudo ambiental a que deve ser submetida a proposta; (2) análise detalhada, que engloba desde a execução do estudo de impacto ambiental até sua análise e tomada de decisão pelo órgão 
competente, com a necessária participação pública; e (3) etapa pós-aprovação, que inclui o monitoramento dos impactos ambientais e medidas mitigadoras, assim como programas de gestão ambiental e auditoria. 


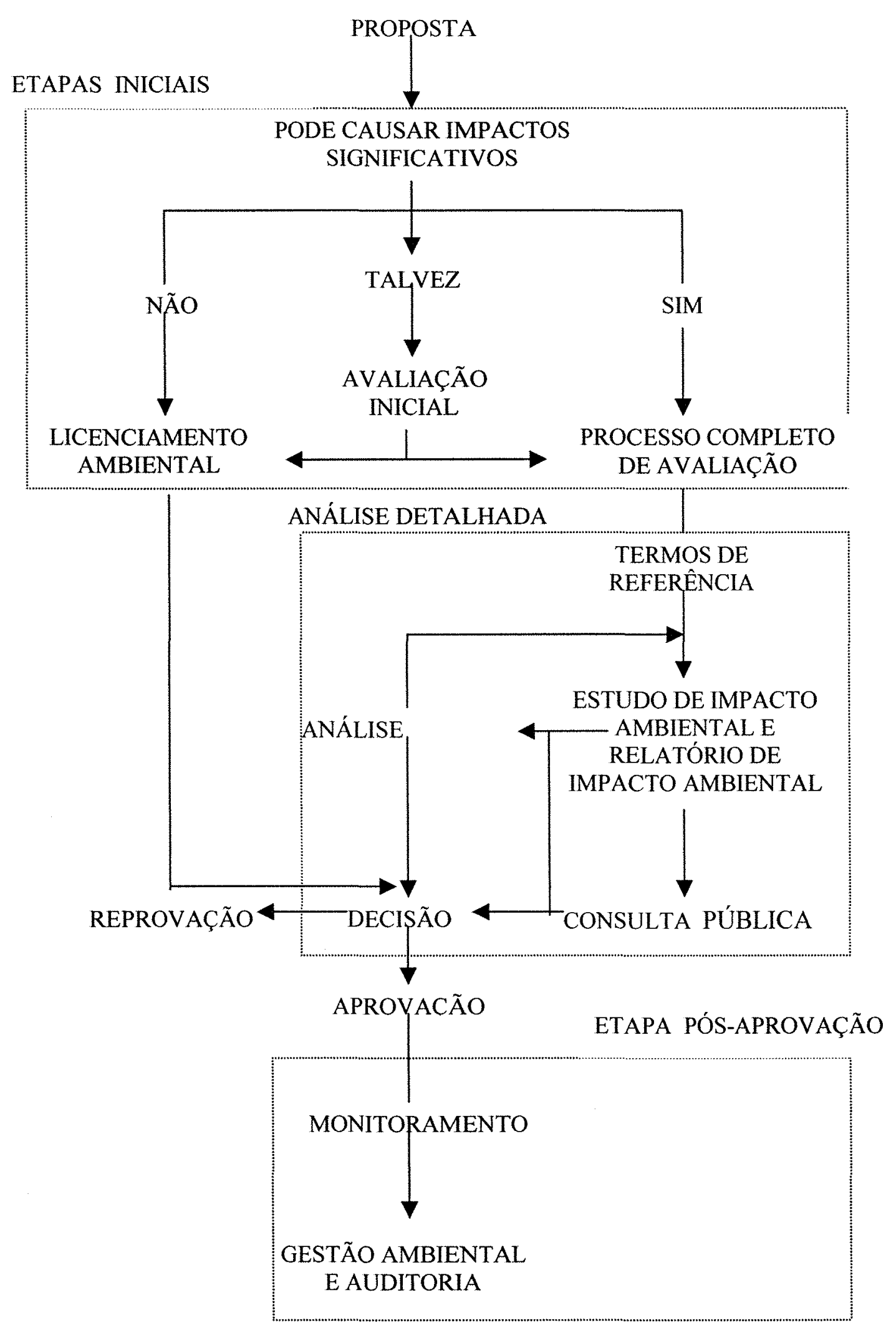

Figura 1 - Processo de avaliação de impacto ambiental Fonte: Sánchez, 1998. 
A AIA tem como objetivos:

a) preservar e restaurar os processos ecológicos essenciais e prover o manejo ecológico das espécies e ecossistemas;

b) preservar a diversidade e a integridade do patrimônio genético do país e fiscalizar as entidades dedicadas à pesquisa e manipulação de material genético;

c) definir, em todas as unidades da Federação, espaços territoriais e seus componentes a serem especialmente protegidos, sendo a alteração e a supressão permitidas somente através da lei, vedada qualquer utilização que comprometa a integridade dos atributos que justifiquem sua proteção;

d) exigir, na forma da lei, para instalação de obra ou atividade potencialmente causadora de significativa degradação do meio ambiente, estudo prévio de impacto ambiental, a que se dará publicidade;

e) controlar a produção, a comercialização e o emprego de técnicas, métodos e substâncias que comportem risco para a vida, a qualidade da vida e o meio ambiente;

f) promover educação ambiental em todos os níveis de ensino e a conscientização pública para a preservação do meio ambiente; proteger a fauna e a flora, vedadas, na forma da lei, as práticas que coloquem em risco sua função ecológica, provoquem a extinção de espécies ou submetam os animais à crueldade.

Além do aspecto preventivo, o conceito de AIA introduz também a noção da compreensão de valoração das ações do homem, pois a AIA exige uma análise exaustiva de todos os impactos que as atividades antrópicas possam causar no meio ambiente.

$\mathrm{Na}$ terminologia do direito ambiental a palavra impacto ambiental aparece também como o sentido de "choque" ou "colisão" de substâncias (sólidas, líquidas ou gasosas), de radiações ou de formas diversas de energia, decorrentes da realização de obras ou atividades com danosa alteração do ambiente natural, artificial, cultural ou social (Milaré, 1998). 
Segundo o Artigo $1^{\circ}$ da Resolução $n^{\circ} 01$ CONAMA, impacto ambiental, significa "qualquer alteração das propriedades físicas, químicas e biológicas do meio ambiente, causada por qualquer forma de matéria ou energia resultante das atividades humanas que, direta ou indiretamente, afetam: i) a saúde, a segurança e o bem-estar da população; ii) as atividades sociais e econômicas; ii) abiota; iv) as condições estéticas e sanitárias do meio ambiente; v) a qualidade dos recursos ambientais".

Deste modo, juridicamente, o conceito de impacto ambiental refere-se exclusivamente aos efeitos da ação humana sobre o meio ambiente. Portanto, fenômenos naturais, como: tempestades, enchentes, incêndios florestais por causa natural, terremotos e outros, apesar de poderem provocar as alterações ressaltadas não caracterizam como impacto ambiental.

A nivel mundial a conceituação do que seja impacto ambiental sob termos jurídicos datam do período da revolução industrial e esta tem sido alterada de forma dinâmica. Fato que se deve aos diferentes tipos de atividades humanas que podem dar origem a formas de matérias e, ou, energias que afetam o meio ambiente. No entanto, a adoção de sistemáticas para avaliação de impactos ambientais teve início somente na década de sessenta (Silva et al., 2002).

O termo "impacto ambiental" vem implicando em um juízo de valor sobre a importância de um efeito ambiental causado pela alteração resultante de um processo físico-natural, pela introdução de um objeto novo ou provocado por atividades humanas ou processos sociais. Existem vários critérios para a qualificação de impactos ambientais. Segundo Leal (1985), com respeito aos impactos sobre os recursos naturais, prevalece o critério da lógica e racionalidade. Esta questiona, fundamentalmente, se a utilização dos recursos naturais disponíveis, a nível global ou regional para implementação de atividades se justifica, especialmente no caso dos recursos renováveis e/ou escassos. A lógica apoiada na ciência indica que as alternativas possíveis são: a) preservá-los e/ou conservá-los; b) desenvolver substitutos; c) buscar usos mais eficientes.

Os impactos sobre a capacidade assimilativa do ambiente são função da capacidade que têm os meios receptores para receber as alterações que não estão dentro 
de sua maneira própria de operar e que superam sua potencialidade de aceitá-las. Leal (1985), diz que os critérios para qualificar os impactos sobre os meios socioeconômicos e culturais possuem caráter subjetivo. Neste campo, a categorização dos impactos prejudica as análises ambientais.

Para Bisset (1985), alguns impactos podem ser caracterizados pela sua reversibilidade. Outros são irreversiveis, isto é, depois que eles ocorrem, a restauração das condições iniciais é impossível. Outros impactos são reversíveis. Por exemplo, o nível de ruído durante uma construção pode superar os níveis ambientais estabelecidos. Após o término das obras, se outras fontes de ruído não forem introduzidas no local, o nível do ruído retorna aos valores prévios do ambiente.

Por outro lado, a intensidade desses processos de alteração depende, em primeiro lugar, do esforço (ou tensão) aplicado pelas atividades humanas ao meio ambiente e, em segundo lugar, ao grau de suscetibilidade à mudança (sensibilidade) do próprio ambiente afetado. Considerando que a natureza das interações que ocorrem no meio ambiente sejam sustentadas por cadeias com elos de força variável, pode acontecer de alguns sistemas naturais se desintegrarem com maior facilidade do que outros, com uma rápida e irreversível modificação em seu todo.

Segundo Bisset (1985) há uma relação importante entre os conceitos de impacto e de resiliência. A resiliência ambiental é um processo de retorno ou não de um sistema às condições anteriores a uma perturbação. A resiliência ambiental pode, também, descrever a resistência do ambiente às mudanças (grau de estabilidade). Esse parâmetro mostra até que ponto o ambiente tolera as mudanças impostas sem que se verifique uma alteração no conjunto do sistema. Cada fator de um sistema natural apresenta um limiar para além do qual a mudança imposta se torna irreversível e é necessário estabelecer um novo equilíbrio.

Canter (1986), cita na literatura sobre estudos específicos de impactos associados a determinados tipos de projetos e, em diversas localidades, avança na categorização de impactos, exemplificando que existem várias classificações, podendo-se listar: impactos positivos e negativos; impactos reversíveis e irreversíveis; impactos reparáveis e irreparáveis; impactos a curto e a longo prazos; impactos temporários e contínuos; 
impactos das fases de implantação, construção, pré-operação, operação, desativação e abandono; impactos locais, regionais, nacionais e globais; impactos acidentais ou planejados; impactos diretos e indiretos; impactos únicos e cumulativos.

Os impactos produzidos sobre os recursos ambientais, advindos da implantação, operação, desativação e abandono de projetos de mineração podem ser identificados a partir das categorias citadas.

\subsection{Estudo de impacto ambiental e relatório de impacto ambiental sobre o meio ambiente}

De acordo com Sánchez (1995a), "a elaboração do EIA é a etapa que possui maior conteúdo técnico-científico do processo de AIA e, normalmente, a que consome mais tempo e recursos: no entanto, ela é apenas um dos elos da cadeia". Os resultados deste estudo, apresentados em relatórios técnicos em geral extensos e complexos, constituem a principal base para a análise da viabilidade ambiental da ação proposta e tomada de decisão. Devido à complexidade dos relatórios do estudo de impacto ambiental, é usual a elaboração de um outro relatório, em linguagem acessível ao público em geral. No Brasil este relatório é conhecido pela sigla RIMA.

O Art. $5^{\circ}$ da Resolução Conama $n^{\circ}$ 001/1986 estabelece as diretrizes gerais que devem nortear a elaboração do estudo de impacto ambiental. São elas: i) contemplar todas as alternativas tecnológicas e de localização confrontando-as com a hipótese de não execução do projeto, ii) identificar e avaliar sistematicamente os impactos ambientais gerados nas fases de implantação e operação da atividade, iii) definir as Áreas Direta e Indiretamente afetadas pelos impactos, e iv) considerar os Planos e Programas de Governo com jurisdição sobre a área onde será implementada a atividade impactante.

O mesmo artigo, em parágrafo único, prevê que além dessas diretrizes gerais, o órgão ambiental competente poderá fixar diretrizes adicionais julgadas necessárias em face das características ambientais da área e das peculiaridades do projeto. 
Um dos principais aspectos que se considera num EIA é a avaliação das alternativas ao projeto. Essa avaliação é exigida pelo art. $5^{\circ}$, I da Resolução 001/1986 do CONAMA. Entre essas alternativas, deve-se considerar as conseqüências de se continuar sem o projeto (não ação), sob o ponto de vista ambiental, social e econômico. Em realidade, não são apenas as alternativas locacionais que devem ser consideradas, mas todas as possiveis, como as tecnológicas, de processos, de disposição final de resíduos, de tratamento de efluentes, de fontes de energia, etc. No Brasil, é ainda difícil encontramos num EIA, a discussão de alternativas locacionais (Tommasi, 1993).

A discussão das alternativas tecnológicas e locacionais se constitui no coração do EIA, dado que, muitas vezes, a melhor opção será a não-execução do projeto, em função dos altos custos sociais e ecológicos dele decorrentes.

Segundo Tommasi (1993), o EIA deve indicar, de forma bastante clara e compreensível, para a comunidade, os prováveis impactos da ação sobre o meio ambiente, que sejam positivos ou negativos, tanto a nível local, como regional e mesmo nacional. A atenção dada aos diferentes fatores ambientais deve variar conforme a importância, natureza, escala e localização da ação proposta.

Para alguns tipos de projeto, no entanto, a discussão de alternativas de localização fica prejudicada pela natureza da atividade. É o caso dos projetos de mineração, que são concebidos para o aproveitamento de jazidas minerais, não podendo ser implantados em outro local. De acordo com Dias (2001), o estudo de alternativas de localização, nesses casos, poderia ser conduzido sob a ótica do atendimento da demanda, mas implicaria o estudo de várias jazidas e a concepção de vários projetos para seu aproveitamento. Este é um procedimento inviável no caso geral, uma vez que para conhecer as características de uma jazida são necessários investimentos, muitas vezes vultosos, em pesquisa mineral.

De acordo com Milaré (1998), a segunda diretriz do conteúdo do EIA é identificação e avaliação sistemática dos impactos ambientais gerados nas fases de implantação e operação da atividade: trata-se de operação tendente a definir as medidas corretivas e mitigadoras dos impactos negativos para o ambiente, para a correta $\mathrm{e}$ oportuna responsabilização do autor do projeto. 
A avaliação de impacto é a etapa na qual se atribui valor, importância e significado aos impactos identificados e previstos. É uma tarefa carregada de subjetividade, uma vez que depende de critérios de importância que, por sua vez, dependem da escala de valores que norteia o julgamento de cada indivíduo ou grupo social. O resultado da avaliação de impacto reflete-se diretamente nas decisões de aprovação de um projeto, assim como na definição das condicionantes para sua aceitação.

Segundo Dias (2001), quanto à segunda diretriz, observa-se que o texto da norma faz referência às fases de implantação e operação da atividade, deixando de contemplar sua desativação, que pode perenizar ou agravar a degradação ambiental do meio socioambiental, ou mesmo causar novos impactos. Esta preocupação está parcialmente contemplada com a inclusão da "recuperação de áreas degradadas" entre os princípios formulados na Lei da Política Nacional do Meio Ambiente (Art. $2^{\circ}$, inciso VIII). Regulamentado a matéria, o Decreto $\mathrm{n}^{\mathrm{o}} 97.632 / 1989$ determinou que "os empreendimentos que se destinam à exploração de recursos minerais deverão, quando da apresentação do Estudo de Impacto Ambiental (EIA) e do Relatório de Impacto Ambiental (RIMA), submeter à aprovação do órgão ambiental competente, plano de recuperação de área degradada".

Desta forma, embora restritos à atividade de mineração, os impactos ambientais gerados na fase de desativação do empreendimento também devem ser identificados e avaliados sistematicamente.

Segundo o Artigo 5..$^{\circ}$ III da Resolução $n^{\circ} 01$ do CONAMA, área de Influência é uma das diretrizes gerais do EIA, que determina o seguinte: "Definir os limites da área geográfica a ser direta ou indiretamente afetadas pelos impactos, denominadas áreas de influência do projeto, considerando em todos os casos a bacia hidrográfica na qual se localiza".

Ainda de acordo com citada Resolução a Área de influência normalmente assume tamanho diferenciado dependendo da variável em questão. Freqüentemente, área de influência é determinada, pela Bacia Hidrográfica, onde viria a localizar-se o empreendimento, mas a variável econômica pode extrapolar essa fronteira e atingir outros municípios. São determinadas escalas apropriadas para seu estabelecimento, 
considerando: área diretamente afetada, área de reassentamento, área de influência indireta, área de influência indireta do reassentamento, área dos municípios diretamente afetados pelo empreendimento regional.

A última diretriz que deve ser considerada trata dos planos e programas governamentais, propostos e em implantação na área de influência do projeto, e sua compatibilidade: importa ter presente, na execução do EIA, a conformidade do projetado empreendimento com eventuais programas e planos, inclusive os plurianuais e aqueles decorrentes do zoneamento ambiental.

Além dessas diretrizes fundamentais, pode o órgão ambiental fixar outras que entenda pertinentes, em razão das peculiaridades do projeto e caracteristicas ambientais da área.

De acordo com Silva et al. (2002) deste modo, considerando-se as abrangências das Áreas Direta e Indiretamente a serem afetadas, o estudo de impacto ambiental deverá no mínimo contemplar as seguintes atividades técnicas: (a) o diagnóstico ambiental, (b) o prognóstico das condições ambientais com a execução do projeto, (c) as medidas ambientais mitigadoras e potencializadoras a serem adotadas e (d) o programa de acompanhamento e monitoramento ambiental,

Segundo Silva et al. (2002), diagnóstico Ambiental consiste na elaboração de uma descrição e análise dos recursos ambientais e suas interações. Portanto, este diagnóstico deverá caracterizar: a) o meio físico - exemplo: solo, subsolo, as águas, ar, clima, recursos minerais, topografia e regime hidrológico; b) o meio biológico: fauna e flora; c) o meio econômico - exemplo: uso e ocupação do solo, uso da água, estruturação socioeconômica da população, sítios e monumentos arqueológicos, históricos e culturais, a organização da comunidade local, e o potencial de uso dos recursos naturais e ambientais da região.

Faz-se uma exposição das interações dos fatores ambientais fisicos, biológicos e socioeconômicos, indicando-se os métodos adotados para sua análise, com o fito de descrever as inter-relações entre os componentes bióticos, abióticos e antrópicos do sistema a ser afetado pelo empreendimento. 
Ainda segundo o autor, o prognóstico refere-se à identificação, valoração e interpretação dos prováveis impactos ambientais associados à execução, e se for o caso, à desativação de um dado Projeto. Desta forma, estes impactos devem ser categorizados segundo os seguintes critérios: a) ordem - diretos ou indiretos; b) valor - positivo (benéfico) ou negativo (adverso); c) dinâmica - temporário, cíclico ou permanente; d) espaço - local, regional e/ou, estratégico; e) horizonte temporal - curto, médio ou longo prazo; e f) plástica - reversível ou irreversível.

O próximo aspecto é a definição das medidas mitigadoras e compensatórias: tratase de medidas a serem adotadas na mitigação dos impactos negativos e potencialização dos impactos positivos. Neste caso, as medidas devem ser organizadas quanto: a) à natureza - preventiva ou corretiva; b) etapa do empreendimento que deverão ser adotadas; c) fator ambiental que se aplicam - físico, biótico e/ou antrópico; d) responsabilidade pela execução - empreendedor, poder público ou outros; e e) aos custos previstos. Para os caso de empreendimentos que exijam reabilitação de áreas degradadas devem ser especificadas as etapas e os métodos de reabilitação a serem utilizados.

De maneira mais detalhada, medidas mitigadoras podem ser definidas como aquelas capazes de suprimir ou reduzir o impacto negativo, e na impossibilidade técnica, econômica ou política de adotá-las, qualquer outra medida é apenas compensatória, ou seja, não mantém as riquezas ecológicas, estéticas e éticas da área afetada, apenas as substitui. As medidas minimizadoras de impactos negativos de empreendimentos, normalmente são indicadas para as perdas na flora, fauna, patrimônio paisagístico, cultural e histórico e social das populações atingidas.

As medidas mitigadoras, enfïm, são aquelas que objetivem minimizar os impactos negativos, sendo portanto, importante que tenham caráter preventivo e ocorram na fase de planejamento da atividade; conseqüentemente, há necessidade de que sejam implementadas e adaptadas às diferentes fases do licenciamento ambiental.

Caso não seja possível mitigar os impactos negativos principalmente sobre o meio biológico, passa-se a determinar medidas de compensação. 
Finalmente, a ultima etapa do estudo de impacto ambiental é a proposição de um plano de gerenciamento ambiental do empreendimento. Fazem parte deste plano as medidas mitigadoras, capazes de atenuar ou eliminar os impactos negativos, as medidas compensatórias, propostas quando os impactos não podem ser evitados e não são passíveis de atenuação, e o plano de monitoramento. Sánchez (1999) lembra, ainda, a necessidade de medidas de valorização dos impactos positivos, propostas para que estes se concretizem em benefício da região onde o empreendimento será implantado, ou seja, da comunidade que irá arcar com os impactos negativos. O plano de monitoramento deve ser capaz de verificar o acerto das previsões, comparando os impactos ocorridos com os previstos, e a eficiência das medidas mitigadoras, além de contemplar mecanismos de intervenção quando reais superarem certos limites.

Há, evidentemente, interação entre as várias etapas, notadamente entre avaliação de impacto ambiental e a proposição de medidas mitigadoras, já que a viabilidade ambiental do empreendimento é decidida com base na avaliação dos impactos ambientais negativos residuais, ou seja, após a aplicação das medidas mitigadoras propostas. Por outro lado, o dimensionamento das medidas mitigadoras, a proposição das medidas compensatórias e a concepção do plano de monitoramento decorrem da importância que foi atribuída aos impactos na fase precedente.

Como pode ser notado, as atividades associadas à realização de estudos de impactos ambientais abrangem vários campos do conhecimento humano. Fato que faz demandar o emprego de diferentes métodos científicos e tecnológicos, e a constituição de uma equipe multidisciplinar.

De acordo Silva et al. (2002), o empreendedor deverá custear todas as despesas decorrentes da: a) contratação da equipe elaboradora; b) condução dos estudos; c) elaboração dos documentos EIA/RIMA e d) tramitação do processo pelo Órgão Licenciador. No entanto, a equipe elaboradora deve ser direta $\mathrm{e}$ indiretamente desvinculada do proponente do projeto. Ou seja, esta equipe deve ser vinculada à empresa responsável pela realização dos estudos.

Segundo Milaré (1998), o objetivo central do estudo de impacto ambiental é simples: evitar que um projeto (obra ou atividade), justificável sob o prisma econômico 
ou em relação aos interesses imediatos de seu proponente, se revele, depois, nefasto ou catastrófico para o meio ambiente. Valoriza-se, na plenitude, a vocação essencialmente preventiva do direito ambiental, expressa na conhecida máxima: é melhor prevenir do que remediar (mieux vaut prevenir que guérir).

De acordo com Moreira (1990), o EIA, é um dos elementos do processo de avaliação de impacto ambiental. Trata-se da execução, por equipe multidisciplinar das tarefas técnicas e científicas destinadas a analisar, sistematicamente, as conseqüências da implantação de um projeto no meio ambiente, por métodos de AIA e técnicas de previsão de impactos ambientais.

No Brasil o EIA é um instrumento orientador e fundamentador da decisão administrativa que autoriza ou não um empreendimento. O EIA é, portanto, um instrumento constitucional da Política Ambiental (art.225, parágrafo $1^{\circ}$, inciso IV da Constituição Federal e art. $9^{\circ}$, inciso III da Lei 6.938/1981). É de elaboração obrigatória, não podendo ser realizado concomitante à obra ou à atividade, devendo ser prévio.

O estudo de impacto ambiental é uma análise e avaliação de atividades planejadas, com vista a assegurar um desenvolvimento não impactante e sustentável.

Segundo Tommasi (1993), aborda que o EIA é exatamente valioso, por contribuir para uma maior informação imparcial sobre um determinado projeto, permitindo que o público possa orientar mais corretamente sua posição em relação ao mesmo, com menos emotividade, sabendo eliminar a influência tanto de grupos políticos como de eliminar a influência tanto de grupos políticos como grupos econômicos.

De acordo com Tommasi (1993), um dos principais objetivos do EIA é a melhoria dos projetos de engenharia, com a incorporação da gestão ambiental.

Para autor o EIA, apesar de fazer parte de nossa legislação, seja um sistema evoluído e com procedimentos bem definidos. Ele em realidade é ainda um tremendo desafio. O EIA é, hoje, cada vez mais reconhecido e utilizado como importante processo para o planejamento, e o desenvolvimento. Se reconhecermos que só há desenvolvimento quando houver: 1 . crescimento econômico; 2. respeito à qualidade de vida; 3. equidade social; o EIA, visando preservar e mesmo melhorar a qualidade 
ambiental, é importantíssimo componente de defesa da qualidade de vida e desempenha papel significativo para o desenvolvimento.

O EIA é o instrumento que, integrado à avaliação de risco, poderá nos garantir que esse tipo de desenvolvimento seja atingido, pois permite que se encontram diretrizes para conservação, gerenciamento e medidas mitigadoras de efeitos de ações impactantes.

Em outras palavras, o processo de avaliação de impactos ambientais tratar-se-ia de um processo sistêmico de avaliação, monitoramento e controle de impactos ambientais decorrentes das atividades humanas, dentro do contexto do desenvolvimento sustentado.

Segundo a Resolução ${ }^{\circ} 001$ de 1986 do CONAMA, deve indicar de forma sucinta, compreensível a toda coletividade, as relações entre a ação proposta e os planos de uso do solo e legislação sobre a área afetada. Isso pode exigir uma síntese de como a ação proposta está de acordo ou em conflito com os objetivos e com os termos específicos de planos locais, federais, estaduais ou municipais. Caso exista um conflito, o EIA deve descrever, claramente, a extensão pela qual o projeto o resolverá. (Tommasi, 1993).

O Relatório de Impacto Sobre o Meio Ambiente (RIMA), aparece nos textos legais como o documento que reflete e formaliza, perante o correspondente órgão público licenciador, o EIA efetuado. A Resolução 001/1986 do CONAMA enfatiza o caráter público e a linguagem objetiva e acessível que devem caracterizar o RIMA, prevendo-se a apresentação em duas versões: uma como síntese destinada à divulgação e outra, integral, para o cumprimento das atribuições do órgão licenciador.

De acordo com Moreira (1990), o Relatório de Impacto Ambiental (RIMA) é o documento que apresenta os resultados dos estudos técnicos e científicos de avaliação de impacto ambiental. Constitui um documento do processo de avaliação do impacto ambiental e deve esclarecer todos os elementos da proposta em estudo, de modo que possam ser divulgados e apreciados pelos grupos sociais interessados e por todas as instituições envolvidas na tomada de decisão.

De acordo com o Art. $9^{\circ}$, parágrafo único da mencionada Resolução 001/1986 CONAMA: "O RIMA deve ser apresentado de forma objetiva e adequada compreensão. As informações devem ser traduzidas em linguagem acessivel, ilustradas por mapas, cartas, quadros, gráficos e demais técnicas de comunicação visual, de modo que se 
possam entender as vantagens e desvantagens do projeto, bem como todas as conseqüências ambientais de sua implementação".

O Art. 11 da mesma Resolução estabelece que respeitado o sigilo industrial, desde que solicitado, o Rima será acessível ao público, permanecendo cópias dos mesmos à disposição dos interessados, nos centros de documentação ou bibliotecas do IBAMA e do órgão estadual de controle ambiental correspondentes, inclusive durante o período de análise técnica.

Uma vez com processo de licenciamento em curso, o órgão Licenciador poderá proceder à realização de audiências públicas que têm por finalidade expor e dirimir dúvidas relacionados ao processo em análise.

Conforme anota Benjamin et al., citado por Milaré (1998), com relação ao EIA/RIMA dois principios fundamentais se destacam: o principio da publicidade e o princípio da participação pública. "Aquele diz respeito ao direito que qualquer cidadão tem de conhecer os atos praticados pelos agentes públicos. Este, de maneira mais extensiva, aplica-se ao direito que tem o cidadão, organizado ou não, de intervir porque é parte interessada - no procedimento de tomada de decisão ambiental".

$\mathrm{O}$ instrumento de garantia mais importante para o efetivo exercício dos princípios acima mencionados é a chamada audiência pública, pois com ela são alcançados dois objetivos: o órgão público presta informações ao público e o público passa informações à administração.

A população tem o direito de tomar conhecimento acerca de uma atividade pretendida e sobre a qual será realizado um estudo de impacto ambiental, podendo acompanhar a realização do EIA e do RIMA, e após a entrega do EIA/RIMA pode-se preparar para a fase de comentários e de audiência pública.

A participação pública não é facultativa, é obrigatória, ocorrendo em todo o processo de avaliação de impacto ambiental, que de forma legal e formal, quer de forma informal, através de pressões junto aos órgãos oficiais envolvidos.

O Edital de Recebimento do RIMA é importante para assegurar a possibilidade de solicitação da Audiência Pública. Caso haja interesse, é dado um prazo de 45 dias (entenda-se dias úteis) para o requerimento da audiência pública por parte dos 
interessados após a publicação do edital. Por ocasião da entrega do EIA/RIMA que deve ser veiculado pela "imprensa local", leia-se município onde será instalado o empreendimento e as várias localidades por ele atingidas (áreas de influência direta e indireta).

Os trabalhos de Audiência Pública são conduzidos pelo órgão licenciador. Devem ocorrer discussões após a exposição objetiva do projeto e de seu respectivo RIMA, não esquecendo do EIA. Após as discussões deve ser elaborada uma Ata sucinta da Audiência, sem ocultar os incidentes ocorridos na sessão. A Audiência Pública é última etapa do procedimento de estudo de impacto ambiental, sendo também base para análise e parecer final.

Segundo Cruz (2000), a tutela do meio ambiente, com sua preservação recuperação e revitalização se tornou um imperativo do Poder Público, com a efetiva participação da sociedade civil, tendo como finalidade assegurar a boa qualidade de vida.

Nos termos da Resolução CONAMA n ${ }^{\circ} .001 / 1986$, "respeitado o sigilo industrial, assim solicitado e demonstrado pelo interessado, o RIMA será acessivel ao público. Suas cópias permanecerão à disposição dos interessados nos centros de documentação da SEMA e do órgão estadual de controle ambiental correspondendo, inclusive ao período de análise técnica (Milaré, 1998).

O autor aborda, a audiência pública a qual "deverá ocorrer em local acessível aos interessados" podendo haver mais de uma sobre o mesmo projeto desde que assim o exija a "localização geográfica dos solicitantes" ou a " complexidade do tema".

A audiência pública foi regulamentada pela Resolução CONAMA nº.009, de 3 de dezembro de 1987.

São quatro as hipóteses de convocação de audiência pública: quando o órgão de meio ambiente "julgar necessário"; quando solicitado por entidade civil; quando solicitado pelo Ministério Público; quando solicitado por cinqüenta ou mais cidadãos.

O licenciamento ambiental coube aos órgãos de controle ambiental, em alguns Estados, até 1986; o sistema de licenciamento aplicava-se regularmente, a projetos de iniciativa privada, principalmente os do setor industrial. Em outros, o sistema foi tardiamente instituído, contando com o apoio da SEMA para sua implementação; a 
Resolução CONAMA 001/1986 fez com que os projetos governamentais, que antes não se sujeitavam ao licenciamento ambiental, tivessem de ser licenciados. A SEMA tinha a preocupação com a capacidade técnica e administrativa dos órgãos estaduais de meio ambiente.

\subsection{O Ministério Público e o estudo de impacto ambiental}

Hoje, o Ministério Público tem um papel essencial na proteção do meio ambiente no Brasil, mas nem sempre foi assim (Milaré, 1998).

Conforme aborda o autor antes da promulgação da Lei $n^{0}$ 6.938/1981 - Lei da Política Nacional do Meio Ambiente - o Ministério Público pouco intervinha nas questões ambientais, especialmente porque lhe faltava uma base legal para tal. Limitava-se, quando muito, a processar criminalmente, com base no código penal, alguns casos de poluição. Os resultados, foram irrisórios e insatisfatórios.

Esse quadro mudou drasticamente com a Lei $n^{\circ}$. 6.938/1981, que em seu artigo 14, parágrafo único, estatui que,"sem obstar aplicação das penalidades previstas neste artigo, é o poluidor obrigado, independente de existência de culpa, a indenizar ou reparar os danos causados ao meio ambiente e a terceiros, afetados por sua atividade. O Ministério Público da União e dos Estados terá legitimidade para propor ação de responsabilidade civil e criminal por danos ao meio ambiente".

Em 1985, foi aprovada a Lei n. 7.347/1985, conhecida como lei de Ação Civil Pública ou lei dos Interesses Difusos, que alargou a legitimidade para propositura das ações para tutela dos chamados "interesses difusos", concedendo-a igualmente, às associações e outros órgãos públicos, além do Ministério Público (Milaré, 1998). 


\section{MATERIAL E MÉTODOS}

\section{1 Área de estudo}

O empreendimento localiza-se na região de Carajás, situada no sudeste do Pará, conhecida pelas riquezas minerais de seu subsolo e que, em razão da abundância na ocorrência de minérios estratégicos, é considerado nos meios técnicos nacional e internacionais como "Província Mineral de Carajás". Nesta região já existem em operação, instalações industriais para extração e produção de minérios de ferro, manganês e ouro. As jazidas minerais de cobre do Sossego estão situada nesta província (MSS, 2000) (Figura 2).

As minas e usina de concentração situam-se no Município de Canaã dos Carajás e a estação de embarque de concentrado, no Município de Parauapebas. O empreendimento foi desenvolvido fora do limite sul da Floresta Nacional de Carajás (FLONACA) (MSS, 2000).

Os estudos para implantação do empreendimento minerário foram desenvolvidos nos municípios de Canaã dos Carajás e Parauapebas, região sudeste do Pará, na Província Mineral de Carajás. 


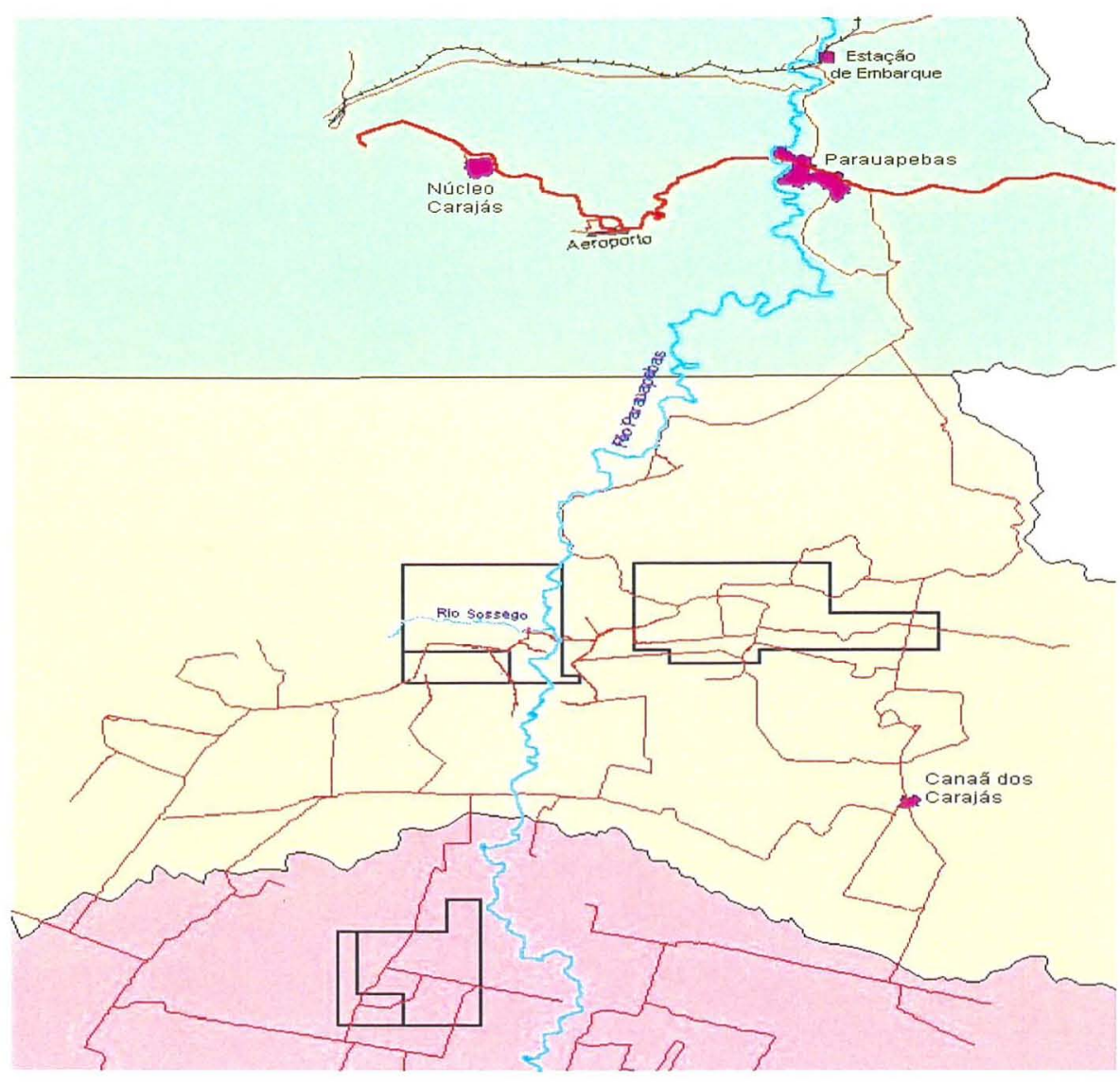

Figura 2 - Localização do Projeto Sossego, junto ao Alvo Sequeirinho no município de Canaã dos Carajás em relação à estação de embarque em Parauapebas. Os dois outros poligonos demarcados referem ao Alvo Serra Dourada (Canãa dos Carajás) e Alvo Canadá no município de Água Azul do Norte, localizados ao sul da Serra de Carajás, região sudeste do Estado do Pará.

Fonte: MSS, 2000.

\subsubsection{Caracterização da área de estudo}

\subsubsection{Clima}

De acordo com a classificação climática de Köppen, que considera a precipitação pluviométrica e a temperatura, a região de Carajás enquadra-se no clima do tipo Am, descrito como tropical-úmido de monção com precipitações excessivas durante alguns meses, e um período bem definido de forte estiagem. Através da classificação de Thorntwaite, que considera os índices de umidade, aridez e eficiência térmica, a região pode ser enquadrada em um tipo de clima úmido com pequena ou nenhuma deficiência de água. 
$\mathrm{O}$ estudo das condições meteorológicas de uma determinada região, com vistas à implantação de um empreendimento, deve avaliar os efeitos da atividade sobre o meio ambiente e deste sobre atividade proposta, principalmente no tocante à qualidade do ar $\mathrm{e}$ das águas.

A região enfocada está inserida em uma área de menor ocorrência pluviométrica, que se estende de Roraima ao leste do Pará, denominada de "corredor amazônico menos chuvoso", entretanto, devido a sua posição altitudinal, é freqüente a ocorrência de chuvas de relevo que incrementam os volumes pluviométricos.

$\mathrm{Na}$ região do sossego a precipitação anual está em torno dos $1.800 \mathrm{~mm}$. As chuvas não estão distribuídas igualmente durante o ano, e a estação seca vai normalmente de maio a outubro.

O Estudo de Impactos Ambientais relata que "na área compreendida entre a Zona do Médio Amazonas e o sudeste do Pará, foram registradas, até à década de 70, temperaturas máximas de $40^{\circ} \mathrm{C}$, estas ocorrendo nos meses de setembro a outubro. Ainda para o Estado do Pará, na região do projeto Sossego, a temperatura mínima encontra-se na faixa de $12^{\circ} \mathrm{C}$ a $16^{\circ} \mathrm{C}$.

Na hidrografia destacam os rios Parauapebas e Sossego, e o córrego Sequeirinho. A rede hidrográfica local, possui cursos d'água intermitentes na época de seca, destacando-se o córrego Sequeirinho, que tem as partes alta e média do seu curso com água apenas na época das chuvas e a parte final com água todo o ano (MSS, 2000).

\subsubsection{Geologia}

\subsubsection{Geologia regional}

A área em estudo encontra-se inserida no contexto da Província Mineral de Carajás, limitada ao norte pela serra da Bacajá, ao sul, pela serra dos Gradaús, a leste, pelos rios Araguaia e Tocantins, e a oeste pelo rio Xingu.

Trata-se de uma região perturbada tectonicamente, o que resultou no intenso imbricamento dos litotipos, nas feições de geometria anostomosada, nos desdobramentos e nas transcorrências. Compreende frações de terrenos retrabalhados do Cinturão Itacaiúnas, e restritamente, frações do Cinturão Araguaia e do terreno Granito- 
greenstone do sul do Pará, além de produtos litoestruturais do Preterozóico. A região mostra-se propícia à exploração de ferro, ouro, cobre, manganês, níquel etc.

O relevo é acidentado com colinas, predominando o morro do Sossego. A pedologia revela solos de baixa fertilidade e presença no subsolo de diversos tipos de rochas. A qualidade do ar indica alta concentração média anual de dióxido de enxofre $\left(\mathrm{SO}_{2}\right)$ e dióxido de Nitrogênio $\left(\mathrm{NO}_{2}\right)$, de acordo com as campanhas de caracterização da qualidade do ar nas duas áreas do Projeto Sossego, na mina e no local do terminal de carregamento ferroviário. A qualidade das águas superficiais, embora apresentando satisfatórias condições físico-químicas e bacteriológicas, não é recomendado o seu consumo "in natura". O nivel de ruídos acusa valores acima dos limites legais na Vila dos Palmares (área residencial), próxima à estação ferroviária de Parauapebas, tendo em vista a movimentação de peças e de veículos e do funcionamento de som mecânico pelas ruas. A avaliação dos minerais radiativos aponta baixo grau de liberação de radiação e baixos teores de urânio e tório (MSS, 2000).

\subsubsection{Vegetação}

No que concerne aos aspectos biológicos na vegetação predominam as pastagens com ocorrência de palmeiras e arbustos (borda sul da FLONACA), juquiras (capoeira) em áreas anteriormente submetidas à garimpagem e lavouras de subsistência. Convém assinalar que a prática de queimadas afugentou a fauna, que ficou reduzida à presença de animais generalistas de áreas antropizadas.

Em decorrência da elevada taxa de intervenção, a atual paisagem da área do Projeto Sossego, é formada predominantemente por pastagens de brachiarão (Brachiaria brizantha), freqüentemente colonizadas por palmeiras e arbustos. Ocasionalmente, observa-se alguma árvore isolada em meio a essas fisionomias. As poucas áreas cobertas por matas existentes na área de influência do empreendimento, incluindo a borda da FLONACA, encontram-se também alteradas (Floresta Ombrófila Densa), seja por fogo, retirada de madeira ou são resultantes da regeneração após uso como roça ou pasto, sendo neste último caso denominadas como "juquirão". 
Nesses ambientes com estrutura arbórea, como nas juquiras, existem diversas espécies em comum entre si, porém com diferenças quanto à densidade e estágio de desenvolvimento das populações (MSS, 2000).

\subsubsection{Aspectos socioeconômicos da região do projeto}

Os Municípios de Parauapebas e Canaã dos Carajás são municípios integrantes da área de influência direta do projeto. Esse estudo priorizou determinados aspectos como demografia, educação, saúde e saneamento, além dos relacionados aos setores produtivos e financeiros (MSS, 2000).

No que se refere à demografia, observa-se uma grande diferença entre os municípios. A população de Canaã dos Carajás representa tão somente $30,86 \%$ da população de Parauapebas; os municípios também apresentam um perfil bem distinto no que se refere à distribuição populacional entre as áreas rurais e urbanas. Parauapebas é um município predominantemente urbano, em que $82,80 \%$ das pessoas vivem na sede do município; em Canaã dos Carajás acontece o oposto, onde a maioria de sua população $(37,70 \%)$ reside no meio rural. No ano de 2000 , Parauapebas registrou uma taxa de crescimento populacional de $12,59 \%$, enquanto que em Canaã, foi de $98,25 \%$. No entanto, estes números devem ser relativizados, uma vez que os dados sobre a população, de 2000 , basearam-se em estimativas.

Os dados sobre educação, demonstram que ano de 2000 foram realizadas 3.009 matrículas no ensino fundamental, com 18 estabelecimentos de ensino públicos, para o município de Canaã dos Carajás, e Paraupebas o número de matrículas chegam em torno 17.249 para o ensino fundamental, contando com 63 estabelecimentos (particular e público).

As informações sobre a saúde revelam um quadro bastante precário, especialmente em Canaã dos Carajás, onde há apenas 1 médico para 10.922 habitantes, enquanto a média estadual é de 1 médico para cada 1.300 habitantes. É também elevado o coeficiente de mortalidade infantil, mas apresentando redução no ano de 1998 era de $58,14 \%$, em 2000 este coeficiente passou a ser de $19,9 \%$ para cada 1.000 nascidos. Em relação aos dados nacionais esse coeficiente pode ser considerado a princípio ainda alto. 
No que se refere ao saneamento básico - serviços de água e esgoto - a situação de Parauapebas é significativamente superior, uma vez que, no ano de 2000 mais de $68,9 \%$ no ano de 2000 das residências contavam com abastecimento regular de água. Este porcentagem só foi possível a partir da efetiva participação da Companhia Vale do Rio Doce (CVRD), intermediando um convênio entre o Banco Mundial (BIRD) e a Prefeitura local. O pagamento do empréstimo, foi realizado a partir de dedução de parte dos "royalties" que a CVRD recolhe ao município.

Em Canaã dos Carajás, por sua vez, os números de domicílios com instalações de água e esgoto é igual a $25,8 \%$.

Quanto aos aspetos produtivos e financeiros observa-se uma enorme desproporção entre os municípios. A estimativa de receita pública per capita de Parauapebas está em torno de R\$ 670, 00 (US\$ 235,08) enquanto que para Canaã é de apenas R\$199,00 (US\$ $69,82)$ o equivalente a $30 \%$ daquele. Esse indicador demonstra uma limitada capacidade de investimentos de Canaã dos Carajás. Por outro lado, em termos produtivos, no setor da pecuária o município de Canaã dos Carajás apresenta um efetivo de rebanho bovino e produção leiteira, expressivamente maiores, embora a população ocupada na agropecuária seja bastante inferior a de Parauapebas.

Em termos de infra-estrutura básica de apoio às atividades produtivas é também enorme a diferença entre os municípios. Parauapebas foi criado pela CVRD, em 1982, como núcleo de apoio ao projeto ferro/Carajás, a partir de recomendação do Banco Mundial. Em 1998 adquiriu autonomia administrativa transformando-se em município com a influência do projeto da CVRD. Embora este tenha gerado externalidades negativas no início do empreendimento, também gerou efeitos benéficos ao municipio, como a construção de aeroportos, estradas pavimentadas, oferta de energia elétrica, eficiente sistema de comunicações etc. Canaã dos Carajás se originou de projetos agrários de colonização, adquirindo uma feição predominantemente rural e ainda não sentiu as externalidades positivas e negativas que o projeto de mineração que está em vias de implantação pode gerar. O município Parauapebas dispõe de ruas pavimentadas, de coleta de lixo $(82,1 \%)$, de sistema de telefonia, de sistema bancário, de eletrificação rural e de aeroportos (MSS, 2000). 


\section{Procedimentos Metodológicos}

\subsection{Estudo de caso}

De acordo com Laville \& Dionne (1999), o estudo de caso incide sempre sobre um caso particular, examinado em profundidade. Não existe preocupação com generalizações.

Ainda de acordo com os autores a vantagem mais marcante dessa estratégia de pesquisa repousa, é claro, na possibilidade de aprofundamento que oferece, pois os recursos se vêem concentrados no caso visado, não estando o estudo submetido às restrições ligadas à comparação do caso com outros casos.

É verdade que as conclusões de tal investigação valem de início para o caso considerado, e nada assegura, a priori, que possam se aplicar a outros casos. Mas também nada o contradiz: pode-se crer que, se um pesquisador se dedica a um dado caso, é muitas vezes porque ele tem razões para considerá-lo como típico de um conjunto mais amplo do qual se torna o representante, que ele pensa que esse caso pode, por exemplo, ajudar a melhor compreender uma situação ou em fenômeno complexo, segundo Laville \& Dionne (1999). Além disso tem sido empregados com êxito em trabalhos que se dispõem a avaliar experiências de intervenção ou de pesquisa (Zioni, 1994).

Dentre os vários tipos de abordagens qualitativas, optou-se por realizar um estudo de caso, visto "desejo de entender um fenômeno social complexo" (Yin, 2001) e, por entender que o foco central refere-se à tentativa de esclarecer "uma decisão ou um conjunto de decisões: porque elas foram tomadas? Como elas foram implementadas? Quais os resultados alcançados" (op. cit.).

De acordo com Yin (2001) um caso de estudo é uma pesquisa que:

a) investiga um fenômeno contemporâneo dentro do contexto da vida real; quando

b) as fronteiras entre o fenômeno e o contexto não são claramente evidentes; $\mathrm{e}$

c) na quais múltiplas fontes de evidências são usadas.

Nisbet \& Watt (1978) citados por Ludke \& André (1986), caracterizam o desenvolvimento do estudo de caso em três fases: sendo uma primeira aberta ou 
exploratória, a segunda mais sistemática em termos de coleta de dados e a terceira consistindo na análise e interpretação sistemática dos dados e a elaboração do relatório.

A fase exploratória coloca-se como fundamental para uma definição mais precisa do objeto de estudo. É o momento de especificar as questões ou pontos críticos, de estabelecer os contatos iniciais para entrada em campo, de localizar os informantes e as fontes de dados necessários para o estudo.

Uma vez definidas as fontes de dados necessários, a próxima etapa foi coleta e o tratamento desses dados.

Segundo Laville \& Dionne (1999), a hipótese guiará essa busca de informações, ao termo da qual a análise permitirá ver se ela resiste à prova dos fatos. Mas é preciso antes transpor uma etapa delicada: a elaboração do quadro operacional da pesquisa.

A hipótese pretende analisar se o EIA/RIMA como documento de licenciamento de grandes projetos na Amazônia, decorrente da Avaliação de Impacto Ambiental, apresentam diversas deficiências estruturais e devem ser aperfeiçoados para que desenvolvam objetivos preferencialmente direcionados para sociedades sustentáveis e para a busca pela melhor qualidade de vida.

De acordo com Laville \& Dionne (1999), os quadros operacionais compõem-se de um conjunto dos indicadores que estabelecem o vínculo entre os conceitos empregados pela hipótese e as observações empíricas necessárias à verificação dessa hipótese. Tem como objeto, inicialmente, concretizar a hipótese em vista de sua verificação empírica. Essa hipótese compreende, na verdade, um ou vários conceitos, e estes são abstratos: é preciso traduzir-lhes as dimensões sob a forma de indicadores que possibilitem a delimitação de suas manifestações.

Mas o quadro operacional é mais do que uma simples escolha de indicadores: estabelece também a ligação entre a hipótese e o trabalho de análise e de interpretação, precisando o que necessita considerar para a verificação da hipótese (Laville \& Dionne, 1999).

Estabelecer o quadro operacional de uma pesquisa consiste em especificar as manifestações observáveis empiricamente ou dos conceitos em jogo e, se na verdade houver vários, explicitar as relações que deveriam aparecer entre as respectivas 
manifestações. É necessário precisar as relações que deveriam existir entre seus respectivos indicadores, à maneira pela qual os valores destes deveriam evoluir em função uns dos outros, de acordo (Laville \& Dionne, 1999).

De acordo com os autores citados o próximo passo é a definição das dimensões possíveis, ou, caso se prefira, seus componentes, aquelas que correspondem à nossa definição do conceito e ao objetivo da pesquisa.

Em seguida seriam selecionados os indicadores, isto é, sinais tangíveis, observáveis na realidade, que permitirão conectar os mesmos ao conceito e permitirão analisar as atitudes, comportamentos, respostas e outras reações coletadas, interpretá-las, para finalmente formular um julgamento. A escolha dos indicadores é, portanto, crucial para o valor e a credibilidade das conclusões da pesquisa (Laville \& Dionne, 1999).

O próximo seria a categorização do indicador; nesse caso foram selecionadas as categorizações ditas ordinais, quando suas diversas categorias são simplesmente hierarquizadas.

É necessário assinalar que o indicador deve permitir mais do que um simples acúmulo de informação, mas conduzir a categorizações de pessoas ou objetos em função da característica do conceito que ele concretiza.

Segundo Laville \& Dionne (1999), para coletar informação a propósito de fenômenos humanos, o pesquisador pode, segundo a natureza do fenômeno e a de suas preocupações de pesquisa, ou consultar documentos sobre a questão, ou encontrar essa informação observando o próprio fenômeno, ou ainda interrogar pessoas que o conhecem. Neste trabalho foram empregados todos esses recursos. Esse procedimento e considerado típico de um estudo de caso que pode ser caracterizado, também, como um estudo em profundidade de um determinado evento a partir de varias fontes de informações secundárias e primárias, quantitativas e qualitativas (Zioni, 1994).

\subsection{Coleta de dados}

A primeira fase da pesquisa iniciou-se com a definição da técnica e dos instrumentos para a coleta dos dados. Dentre os procedimentos indicados para coleta de dados em estudo de caso, utilizou-se à pesquisa com base documental, que complementa 
os dados obtidos através da observação e que aponta novos aspectos da realidade pesquisada.

Ludke \& André (1986) salientam a importância da análise documental na abordagem de dados qualitativos "(...) seja complementando as informações obtidas por outras técnicas, seja desvelando aspectos novos de um tema ou problema".

Através da utilização desta ferramenta é possível "(...) identificar informações factuais nos documentos a partir dos interesses da pesquisa. Por exemplo, legislação, estatuto (regulamentos, normas), pareceres, relatórios técnicos, jornais, discurso" (Ludke \& André, 1986).

Foram feitos os seguintes levantamentos das informações junto aos órgãos oficiais para obtenção dos dados em Belém como: Secretaria Executiva de Ciência Tecnologia e Meio Ambiente (SECTAM), Departamento Nacional de Produção Mineral (DNPM), Instituto Brasileiro de Meio Ambiente e dos Recursos Naturais Renováveis (IBAMA), (como órgãos licenciadores do Projeto Serra do Sossego), além da Companhia Vale do Rio Doce/Mineração Serra do Sossego (CVRD/MSS) e Secretaria Executiva de Indústria Comércio e Mineração (SEICOM), onde foram examinados documentos e registros técnicos e administrativos.

Neste levantamento foram consultados na SECTAM, o Estudo de Impacto Ambiental e o Relatório de Impacto Ambiental (EIA/RIMA), os quais, juntamente com os 23 Programas de Controle Ambiental, foram apresentados pela MSS junto à Secretaria para licenciamento ambiental do empreendimento.

Para conhecimento das condições do local de estudo, foi feita uma visita a campo no período de 26 de dezembro de 1999 a 15 de janeiro de 2001, onde os contatos realizados, serviram para conhecer a realidade socioeconômica dos Municípios de Canaã dos Carajás e Paraupebas.

Estas observações foram importantes para definição dos elementos da pesquisa e delimitação do problema, bem como para a elaboração dos critérios para a escolha de um grande projeto na Amazônia. 
Durante alguns meses acompanhou-se na Mineração Serra do Sossego, o licenciamento ambiental do empreendimento, feito pelo órgão ambiental do Pará, os documentos foram analisados e fazem parte da dissertação (Anexo 1).

Segundo Laville \& Dionne (1999) após esta fase de levantamento das informações os dados foram preparados, posteriormente agrupados e classificados por categorias: tais classificações, que às vezes remontam à elaboração dos instrumentos, grades ou questionários já supõem uma forma de análise e de interpretação das informações, estejam elas já presentes ou se trate daquelas que se pretende coletar.

De acordo Laville \& Dionne (1999), para melhor descrever as diversas operações, distinguem-se, às vezes, preparação, análise e interpretação dos dados; deve-se ao mesmo tempo convir que as demarcações entre elas não são estanques, nem sempre claramente discerníveis.

\subsection{Pesquisa qualitativa}

Destacam, desta abordagem, as seguintes características sobre pesquisa qualitativa, conforme Bogdan e Biklen ${ }^{1}$ (1982) citados por Ludke e André (1986): o ambiente natural como sua fonte direta de dados e o pesquisador com seu principal instrumento; os dados coletados são predominantemente descritivos; o processo é muito maior do que com o produto; o foco de atenção do pesquisador está, especialmente, no significado que as pessoas dão as coisas e à sua vida; preocupação em retratar a perspectiva dos participantes; e a análise dos dados tende a seguir um processo indutivo. Isso não significa portanto a inexistência de um quadro teórico que oriente a coleta e análise dos

dados. Dentro da abordagem qualitativa, destaca-se o estudo de caso, muito útil para o desenvolvimento desta pesquisa.

Segundo Minayo (1992), citado Zioni (1994) em contrapartida, nas abordagens qualitativas a preocupação recai com menor intensidade na generalização e mais no

${ }^{1}$ 'Bogdan, R. Biklen, S.K. Qualitative Reseaarch for Education. Boston:Allyn and Bacon, 1982. p.1-8 
aprofundamento e abrangência da compreensão seja de um grupo social, de uma organização, de uma instituição, de uma política ou de uma representação.

Partilha-se do pressuposto desta mesma autora de que a pesquisa qualitativa responde a questões particulares, preocupando-se com um nível de realidade que não pode ser quantificado. Ou seja, este tipo de pesquisa trabalha com o universo de significados, motivos, aspirações, crenças, valores e atitudes, o que corresponde a um espaço mais profundo das relações, dos processos e dos fenômenos que não podem ser reduzidos à operacionalização de variáveis.

Desta perspectiva, a teoria das Representações sociais constitui-se em uma forma de abordagem das questões ambientais privilegiada, na medida em que propicia, a partir do desvelamento da subjetividade de um dado grupo, a compreensão em profundidade de uma faceta da relação tão complexa homem-meio ambiente, a partir do universo de significados que aqueles sujeitos constroem na sua relação com o mundo (Zioni, 1994).

Cabe ressaltar que essa pesquisa trilhou um percurso entre o empírico e o teórico o que possibilitou desdobramentos que contribuíram para redefinir o próprio projeto, às hipóteses e às abordagens metodológicas.

\subsection{Questionários}

Segundo Laville \& Dionne (1999), para coletar informação a propósito de fenômenos humanos, o pesquisador pode, segundo a natureza do fenômeno e a de suas preocupações de pesquisa, ou consultar documentos sobre a questão, ou encontrar essa informação observando o próprio fenômeno, ou ainda interrogar pessoas que o conhecem.

O questionário tem a finalidade de obter, de maneira sistemática e ordenada, informações sobre as variáveis que intervém em uma investigação, em relação a uma população ou amostra determinada. Os questionários foram encaminhados e respondidos pelos entrevistados, no qual por este motivo constou de uma explicação resumida dos objetivos da pesquisa, instrução para o preenchimento. 
A opção feita na presente pesquisa, foi de utilizar questionários como estratégia de pesquisa de opinião, valendo-se do tipo padronizado ou uniformizado. Este pode ser entendido como um instrumento privilegiado de sondagem; mas seu uso não se limita, todavia, a esta única estratégia de pesquisa de acordo com Laville \& Dionne (1999). Em função da hipótese de trabalho e das exigências de sua verificação, foram escolhidas várias perguntas, oferecendo aos profissionais várias opções de respostas, definida a partir dos indicadores.

Ainda de acordo com os autores dentre as vantagens desse tipo de questionário padronizado (diz padronizado também uniformizado), pode-se lembrar que se mostra econômico no uso e permite alcançar rápida e simultaneamente um grande número de pessoas, uma vez que elas respondem sem que seja necessário enviar-lhes um entrevistador.

A evolução tecnológica na informática e nas telecomunicações abre um conjunto de novas perspectivas para o pesquisador, permitindo o acesso e novos e modernos métodos de coleta de dados. Os públicos alvos da pesquisa foram vários especialistas de notório conhecimento na área ambiental, como consultores, técnicos (analistas de EIA/RIMA), professores das universidades, empresas de consultoria e profissionais liberais que trabalham com o assunto pesquisado em diferentes Estados do Brasil, para os quais foram encaminhados 112 questionários, sendo que apenas $25 \%$ (28) foram devolvidos ao expedidor.

Esta taxa vai ao encontro de outras experiências nas quais sempre é detectado o problema do baixo retorno.

\subsection{Análise e interpretação dos dados}

Para análise dos dados coletados através dos questionários utilizou-se para elaboração, tabulação e análise dos dados o software Microsoft Excel for Windows. Foram realizadas as análises críticas e descritivas dos questionários aplicados.

Dentro desta proposta, adotou-se a estratégia metodológica de triangulação de dados, a partir da técnica de pesquisa documental, objetivando concomitantemente uma 
maior validade dos dados e uma inserção mais aprofundada da pesquisadora (Zioni,1994).

Spink \& Palos 2000, citado por Zioni (1994) remete a introdução do processo de análise através da triangulação de dados, a Denzin na década de 70 . Segundo aquela autora este desenho de procedimento metodológico procurava estabelecer bases para uma validação dos dados no sentido do termo, isto é, como busca da essência do fenômeno na relação entre o real e a teorização sobre o real.

Denzin (1978) citado por Janesick (1999) apresenta quatros tipos de triangulação, quais sejam:

i) a triangulação de dados, que consiste na utilização de múltiplas estratégias de amostragem;

ii) a triangulação de pesquisadores, que se baseiam no uso de diversos pesquisadores ou avaliadores;

iii) a triangulação de teorias, que utiliza variadas perspectivas na interpretação de um único tipo de dado;

iv) a triangulação metodológica, que consiste na utilização de múltiplos métodos para estudar um único problema.

Assim, utilizou-se a coleta dados e de teorias para analisar as informações coletadas e, partir desta análise elaborar uma síntese ou, no caso específico, as considerações referentes ao estudo de realizado.

Com base nesse pressupostos teóricos, buscou-se a inter-relação entre os fatos, avaliando-se que esta seja um terreno fértil para uma compreensão mais abrangente dos significados construídos socialmente na relação dos sujeitos com o meio.

Para analisar as respostas sobre as falhas estruturais de EIA/RIMA, utilizou-se de tabelas e gráficos para melhor visualizar. A principal finalidade da pesquisa realizada, junto aos especialistas da área ambiental, foi levantar informações sobre Avaliação de Impacto Ambiental tendo como procedimento EIA/RIMA.

Concordando com Ludke \& André (1986), que categorização, por si mesma, não esgota a análise, constata-se que é preciso que o pesquisador vá além, ultrapasse a mera descrição, buscando realmente acrescentar algo à discussão já existente sobre o assunto 
pesquisado, procurou-se relacionar os dados categorizados às descobertas feitas durante a pesquisa bibliográfica, principalmente com base nas obras dos autores Elisabeth Monosowski, Luis Henrique Sánchez e, posteriormente, com base nas reflexões de Dias (2001) que, em sua pesquisa de doutorado, trabalhou com proposta semelhante.

Foram analisados os seguintes documentos, após os levantamentos das informações referentes ao empreendimento, que servirão como exemplo, para correlacionar-se com as falhas estruturais apresentadas no EIA/RIMA da Mineração Serra do Sossego e nos fatores que interferem e dificultam a implementação do estudo de impacto ambiental:

1) Análise do Estudo de Impacto Ambiental o Relatório de Impacto Ambiental (EIA/RIMA) da MSS, relativos aos aspectos socioeconômicos;

2) Análise do Parecer da Secretaria Executiva de Ciência, Tecnologia e Meio Ambiente (SECTAM): Licença Prévia (LP); Licença de Instalação (LI), conforme (Anexo 2).

3) Análise dos Programas de Controle Ambiental:

1) Programa de Compensação, Inserção e Comunicação Social;

2) Programa de Monitoramento (item II) e Monitoramento de parâmetros socioeconômicos (itens II. e II.2);

3) Programa do Controle Nosológico e do Quadro Geral de Saúde;

4) Programa de Relocação; Programa de Educação Ambiental;

5) Sistema de Gestão Ambiental (SGA);

6) Plano Desenvolvimento Sustentável para o Município de Canaã dos Carajás (PDS) Programa de Trabalho;

7) Levantamento sobre as falhas estruturais do EIA/RIMA e dos fatores que interferem na eficiência do mesmo, (Anexo 8).

A análise realizada também considerou as seguintes legislações ambientais: 
a) 225 , No $\S 1^{\circ}$, inciso IV, No $\S 2^{\circ}$ e o parágrafo $3^{\circ}$ do artigo 225 da Constituição Federal do Capítulo do Meio Ambiente;

b) Lei $\mathrm{n}^{\circ} 6.938$, de 31 de Agosto de 1981, que institui a Política Nacional do Meio Ambiente (PNMA);

c) Resolução ${ }^{\circ}$ 001, de 23 de janeiro de 1986; do Conselho Nacional de Meio Ambiente (CONAMA), que dispõe sobre a obrigatoriedade do EIA/RIMA como condicionante ao licenciamento de atividades impactantes;

d) Lei $237 / 97$ do Instituto Brasileiro do Meio Ambiente e dos Recursos Naturais Renováveis (IBAMA) e;

e) Legislação Estadual Lei $n^{\circ} 5.887$, de 9 de maio de 1995 que dispõe sobre a Política Estadual do Meio Ambiente do Estado do Pará, Capítulo IV do Monitoramento, Capítulo VIII Do Licenciamento Ambiental, Capítulo IX Da Avaliação Prévia de Impactos Ambientais, Capítulo X Das Audiências Públicas, Capítulo XI da Fiscalização Ambiental.

\section{Principais documentos examinados}

\subsection{O Estudo de impacto ambiental (EIA/RIMA)}

Uma empresa de consultoria independente foi contratada para desenvolver os estudos, avaliar, analisar e elaborar o EIA/RIMA. Os estudos, levantamentos e amostragens foram realizados por outras equipes que desenvolveram trabalhos específicos para MSS.

A MSS apresentou para análise ambiental junto a SECTAM o Estudo de Impacto Ambiental (EIA) e o Relatório de Impacto Ambiental (RIMA), protocolados sob o $\mathrm{n}^{\circ}$ 57.869/2000, cujo objetivo foi à obtenção da Licença Prévia (LP), conforme preconiza a legislação vigente.

Após avaliação do Estudo de Impacto Ambiental (EIA), vistoria técnica ao local do empreendimento, realização de Audiência Pública no Município de Canaã dos Carajás e Parecer do Conselho Estadual de Meio Ambiente, foi emitida a Licença 
Prévia, juntamente com condicionantes referentes à licença. Dando seqüência ao licenciamento ambiental a MSS solicitou a Licença de Instalação, com a apresentação de 28 Programas de Controle Ambiental.

A Licença de Instalação foi emitida, também com condicionantes, e está em vigor.

\section{Descrição do empreendimento}

A Mineração Serra do Sossego propõe a exploração, produção e comercialização de concentrado de minério de cobre, contendo ouro como subproduto; localiza-se ao sul da Serra dos Carajás, no Município de Canaã dos Carajás, Estado do Pará, em uma área controlada pela Mineração Serra do Sossego S.A.

O empreendimento compreende as operações de mina, usina de concentração de minério, barragem de rejeitos e unidades de apoio (oficinas, prédios administrativos, laboratório e refeitório).

A mineração a céu aberto irá ocorrer nos morros do Sossego, Sequeirinho e Serra Dourada, com localização contigua à Floresta Nacional de Carajás, prevendo-se uma vida útil de, pelo menos, 15 anos.

As áreas em questão já sofreram profundas modificações antrópicas, ocasionada por desmatamentos, garimpagem e pecuária extensiva.

A Área Diretamente Afetada será de 5.712 ha, prevendo-se a implantação de uma estrada ligando a Usina de Concentração ao centro de carregamento ferroviário, numa extensão total de $84 \mathrm{~km}$, e, ainda, uma linha de transmissão de energia elétrica de 230 KW.

\section{Descrição dos impactos ambientais}

\subsection{Etapa de implantação}

Os critérios abaixo descritos foram padronizados, a partir do estudo e aplicação de diversas metodologias de avaliação de impacto ambiental, consideradas as leis e resoluções pertinentes, em especial a Resolução 001/1986, e segundo (MSS, 2000), elaborado pela empresa consultora para avaliar os impactos, decorrentes da implantação do empreendimento. Os critérios foram organizados segundo os conceitos descritos a seguir. 
a) Intensidade: indica as conseqüências que o impacto gera sobre o meio. Foi padronizada nos seguintes níveis, conforme Quadro 1.

\begin{tabular}{|l|l|}
\hline Baixa (1) & $\begin{array}{l}\text { Impacto positivo ou negativo pouco mensurável ou pouco provável (que } \\
\text { pode não ocorrer ou não ser percebido) e que não terá conseqüências } \\
\text { importantes sobre o ambiente. }\end{array}$ \\
\hline Média (3) & $\begin{array}{l}\text { Impacto positivo mensurável ou sensível, de conseqüências pouco notáveis e } \\
\text { que não gera modificações estruturais no ambiente em estudo. } \\
\text { Impacto negativo mensurável ou sensível, de conseqüências pouco notáveis } \\
\text { e que esteja dentro de parâmetros legais e normativos, sendo portanto } \\
\text { assimilável pelo ambiente em estudo. }\end{array}$ \\
\hline Alta (5) & $\begin{array}{l}\text { Impacto positivo que será capaz de modificar de forma importante, } \\
\text { qualitativa e quantitativamente, o ambiente em estudo e sua estrutura, sob a } \\
\text { ótica considerada. } \\
\text { Impacto negativo que, de alguma forma esteja fora de normas, padrões e } \\
\text { requisitos legais, ou na falta destes que esteja acima da capacidade de } \\
\text { absorção do ambiente em estudo. }\end{array}$ \\
\hline Muito Alta (7) & $\begin{array}{l}\text { Impacto positivo que alterará profundamente a estrutura e a característica do } \\
\text { ambiente em estudo, sob a ótica considerada. } \\
\text { Impacto negativo com conseqüências catastróficas e acima da capacidade de } \\
\text { absorção do ambiente/comunidades, com potencial ação rigorosa por parte } \\
\text { de órgãos ambientais e população, a ponto de inviabilizar o } \\
\text { empreendimento. }\end{array}$ \\
\hline
\end{tabular}

Quadro 1 - Intensidade dos impactos ambientais

Fonte: MSS (2000)

b) Abrangência: indica a extensão sobre a qual o impacto age, podendo ser verificadas no Quadro 2.

\begin{tabular}{|l|l|l|}
\hline Pontual (1) & $\begin{array}{l}\text { Impacto que atua diretamente sobre um ponto determinado, não se } \\
\text { configurando como distribuído em toda a Área Diretamente Afetada } \\
\text { (ADA) do empreendimento. }\end{array}$ \\
\hline Local (3) & $\begin{array}{l}\text { Impacto que age sobre a Área Diretamente Afetada (ADA) do } \\
\text { empreendimento, podendo ainda incluir a Área de Entorno (AE). }\end{array}$ \\
\hline Regional (5) & $\begin{array}{l}\text { Impacto que age sobre a Área de Influência Indireta (AII) do } \\
\text { empreendimento. }\end{array}$ \\
\hline Global (7) & $\begin{array}{l}\text { Impacto que extrapola a Área de Influência Indireta (AII) do } \\
\text { empreendimento, tendo características de impacto sobre o ambiente sem } \\
\text { limite geográfico para seus efeitos. }\end{array}$ \\
\hline
\end{tabular}

Quadro 2 - Abrangência dos impactos ambientais

Fonte: MSS (2000)

c) Significância: relação entre intensidade e abrangência (A/B), conforme Quadro 3. 


\begin{tabular}{|l|c|l|}
\hline \multicolumn{1}{|c|}{ Significância } & Critérios A/B & \multicolumn{1}{|c|}{ Conceitos } \\
\hline \multirow{2}{*}{ Desprezivel } & $1 / 1$ & Impacto de baixa intensidade e pontual; \\
& $1 / 5$ & Impacto de baixa intensidade e restrito à ADA; \\
& $1 / 3$ & Impacto de baixa intensidade, atuante sobre ADA e AII. \\
\hline \multirow{2}{*}{ Marginal } & $3 / 1$ & Impacto de média intensidade, porém pontual. \\
& $1 / 3$ & Impacto de média intensidade restrito a ADA; \\
& $3 / 5$ & Impacto de baixa intensidade, de abrangência global; \\
Crítica & & Impacto de média intensidade atuante sobre ADA e AII. \\
(impactos & $5 / 1$ & Impacto de alta intensidade, de abrangência pontual; \\
negativos) ou & $3 / 7$ & Impacto de alta intensidade, de abrangência sobre a \\
Relevante & $5 / 3$ & ADA; \\
(impactos & $5 / 5$ & Impacto de alta intensidade, de abrangência sobre a ADA \\
positivos) & $7 / 1$ & e AlI; \\
& & Impacto de intensidade muito alta, de abrangência \\
\hline Catastrófica & & Impacto de intensidade muito alta, de abrangência sobre a \\
(impactos & $7 / 3$ & ADA; \\
negativos) ou & $5 / 7$ & Impacto de alta intensidade, com efeito global; \\
Estratégica & $7 / 5$ & Impacto de intensidade muito alta, de abrangência sobre a \\
(impactos & $7 / 7$ & ADA e AII; \\
positivos) & & Impacto de intensidade muito alta, de abrangência global. \\
\hline
\end{tabular}

Quadro 3 - Significância dos impactos ambientais

Fonte: MSS (2000)

d) Incidência: a incidência do impacto sobre o meio impactado pode ser: direta e indireta.

e) Tendência: a tendência do impacto no tempo pode ser: progredir (tendência de aumento do impacto prognosticado ou identificado); manter (tendência de manutenção do impacto prognosticado ou identificado); regredir (tendência de redução do impacto prognosticado ou identificado).

f) Reversibilidade: o impacto pode ser: reversível (quando, cessada a origem ou controlado o impacto, o meio impactado pode voltar a sua condição original); irreversível (quando, cessada a origem ou controlado o impacto, o meio impactado não mais retorna à sua condição original).

g) Efeito: o efeito do impacto pode ser: positivo, quando atua favoravelmente ao aspecto ambiental em análise; negativo, quando atua desfavoravelmente ao aspecto ambiental em análise. 
h) Impactos potenciais e reais: a avaliação de impactos ambientais de um empreendimento pode ser feita segundo dois pontos de vista:

i) Avaliação de impactos potenciais: indica os impactos que o empreendimento, conforme planejado, poderá causar, desconsiderando-se os sistemas de controle projetados $\mathrm{e}$ as demais medidas mitigadoras previstas. Tem como objetivo o conhecimento do potencial impactante da atividade e, principalmente, a identificação das medidas de mitigação. Esta avaliação, entretanto, não permite o conhecimento dos impactos que efetivamente serão gerados pelo empreendimento já que, adotadas as medidas de mitigação planejadas, estes impactos não ocorrerão, conforme a (MSS, 2000).

Entretanto, não se pode concordar com esta afirmação da MSS (2000), pois as medidas de mitigação apenas reduzem as intensidades dos impactos negativos.

ii) Avaliação de impactos reais: indica os impactos que o empreendimento causará, considerando-se todos os sistemas de controle projetados e as demais medidas mitigadoras planejadas. Esta deve ser a avaliação a ser considerada, para verificação da viabilidade ambiental do empreendimento, de acordo com a (MSS, 2000).

A metodologia elaborada para a MSS (2000), apresenta para o mesmo impacto ambas avaliações, com indicação das medidas mitigadoras que determinam os impactos reais, com características diferentes entre si. Observa que é possível a existência de impactos reais que, mesmo após a aplicação das medidas mitigadoras, mantenham-se com a mesma classificação dos potenciais. Isto por se tratar de impactos não mitigáveis (quando se trata de impactos de maior intensidade) ou que não poderiam ser reduzidos a níveis menores (quando já se encontram nos níveis mais baixos possíveis).

Ao final da avaliação descritiva de impactos para cada fase do empreendimento, é apresentado um quadro-resumo, classificando-se cada impacto prognosticado segundo os critérios de avaliação elaborada pela empresa consultora, sempre se considerando os impactos reais. Os quadros 7.1.11,7.2.19 e 7.3.25 apresentam o resumo para cada fase.

Considerando-se a avaliação de impactos reais do empreendimento, procede-se à análise da viabilidade e da relação custo/benefício deste, sob o ponto de vista ambiental. 
Estando a intensidade dos impactos negativos reais do empreendimento situados em níveis de baixa a média, tendo em vista a definição dos mesmos, critérios de avaliação dos impactos a MSS (2000) afirma que: as conseqüências dos impactos ambientais do empreendimento são admitidas pelas leis e normas pertinentes; as conseqüências dos impactos ambientais do empreendimento são assimiláveis pelo ambiente.

A significância dos impactos negativos reais do empreendimento, neste caso, estaria situada entre desprezível e marginal, exceto quando as consequiências dos mesmos forem de abrangência global, onde apresentam significância crítica, indicando neste caso a necessidade de ações mais rigorosas no controle dos mesmos.

De acordo com a MSS (2000), havendo impactos negativos reais de intensidade alta a muito alta, há um indicativo de que as conseqüências dos impactos do empreendimento estão acima do permitido pelas leis e normas pertinentes, ou não são assimiláveis pelo ambiente. Estes impactos terão significância de crítica à catastrófica. Neste caso, a princípio, não há viabilidade ambiental do empreendimento na forma proposta, ou as medidas mitigadoras são insuficientes. Entretanto, em alguns casos, mesmo quando o parâmetro significância se referir a um impacto não assimilável, podese indicar medidas de compensação adicionais, a serem negociadas no processo de licenciamento, a partir de uma relação custo/benefício favorável à implantação do empreendimento.

Segundo a MSS (2000) deve-se considerar também os impactos negativos potenciais avaliados. Isto porque, caso estes tenham intensidade alta a muito alta, podese deduzir que as medidas mitigadoras deverão ser eficientes a ponto de mitigá-los em níveis aceitáveis. Deverá haver também, neste caso, um sistema eficiente de monitoramento, tendo em vista a necessidade de garantir estes resultados.

Ainda o EIA afirma que em alguns casos, mesmo considerando-se medidas de mitigação, os impactos potenciais e reais poderão estar nos mesmos níveis. Isso demonstra tratar-se de impactos não mitigáveis, inerentes à realização do empreendimento. Ainda assim, deve-se considerar possiveis medidas mitigadoras, em especial de compensação, que podem atenuá-los. 
De acordo com a MSS (2000), para análise custo/benefício do empreendimento, além da abordagem da viabilidade ambiental do empreendimento, serão considerados os impactos positivos reais a serem gerados pelo mesmo, avaliando-os em relação aos impactos negativos reais analisados.

O estudo ambiental faz uma abordagem sobre as tendências da qualidade ambiental da área avaliada segundo a hipótese de não realização do empreendimento. Esta análise tem como objetivo apresentar elementos de comparação que possibilitem traçar um paralelo entre as condições ambientais futuras com e sem o comprometimento do projeto.

O fundamento da análise de tendência é o cenário futuro desenhado para a região. Este cenário baseia-se na continuidade dos atuais processos de uso e ocupação do espaço rural na região, expressivos na área, tais como:

a) as formas de ocupação atuais vêm reduzindo muita a vegetação natural, com uma predominância das formações antrópicas, tais como pastagens, poucas culturas de subsistência e recortes de formações vegetais em diversos estágios de regeneração. Caso não ocorra nenhum grande evento econômico de origem externa na área, este quadro não deverá ter alteração;

b) o cenário futuro para o meio socioeconômico se caracteriza pela tendência de concentração das terras produtivas, com predominância da pecuária extensiva como atividade rural, com redução das oportunidades de trabalho, e gradual deteriorização das condições, já precárias, de vida das populações das Vilas da área do entorno;

c) segundo a MSS (2000), caso o empreendimento não venha a se implantar, o município de Canaã dos Carajás perde a oportunidade imediata de desenvolver a sua economia no segmento mineral, e conseqüentemente perde a oportunidade de ter ampliado a sua receita fazendária, e desta forma, deixa de proporcionar ganhos na melhoria de sua infra-estrutura urbana, comunitária, e na geração de renda e postos de trabalho. De acordo com a MSS (2000), a expectativa de implantação de um empreendimento minerário por parte da Mineração Serra do Sossego é um fator que tem contribuído para a permanência de parte da população residente na área em estudo e 
mesmo nas outras vilas como o CEDERE III, Vila Feitosa, o Treze e outras situadas nas proximidades;

d) diante da escassez dos meios de sobrevivência, tais como oferta de trabalho, aliada às precárias condições de vida da população residente, no que diz respeito aos serviços de saúde, educação, saneamento, etc., pode-se deduzir que, não havendo o empreendimento, permanecerá a tendência ao declínio das atividades rurais agrícolas na região, com redução espontânea da população residente nas vilas da área em estudo e nas demais vilas próximas, cujo quadro socioeconômico apresenta semelhanças com as mesmas.

De acordo com a MSS (2000), é estimado que nos impactos sobre o meio antrópico ocorrerá à criação de 3.000 empregos na fase de implantação do empreendimento, alocados nas obras de terraplenagem, construção civil, montagens eletromecânicas e serviços de apoio, gerando efeito positivo, alta intensidade, incidência direta e inserção social na população local.

A MSS (2000) classifica, no Quadro 4, este impacto como positivo, com intensidade alta, já que será capaz de modificar de forma importante a estrutura do ambiente socioeconômico e possui abrangência regional, pois extrapola a área de influência indireta do empreendimento. A significância neste caso é caracterizada como relevante, de acordo com EIA.

\begin{tabular}{|c|c|c|c|}
\hline CRITÉRIO & $\begin{array}{c}\text { IMPACTO } \\
\text { POTENCIAL }\end{array}$ & MITIGAÇÃO/CONTROLE & IMPACTO REAL \\
\hline Efeito & Positivo & & Positivo \\
\hline Intensidade & Alta & \multirow{4}{*}{$\begin{array}{c}\text { Inserção social - Priorização da } \\
\text { população local }\end{array}$} & Regional \\
\hline Abrangência & Regional & Relevante \\
\hline Significância & Relevante & & Direta \\
\hline Incidência & Direta & & Manter \\
\hline Tendência & Regredir & & Irreversível \\
\hline Reversibilidade & Reversível & & \\
& & & \\
& & &
\end{tabular}

Quadro 4 - Criação de empregos

Fonte: MSS (2000)

A MSS (2000), prevê ainda, incremento na renda regional, via aquecimento na economia dos Municípios de Canaã dos Carajás e Parauapebas. 
De acordo com o documento acima mencionado impacto é positivo, com intensidade alta já que será capaz de modificar de forma relevante o ambiente socioeconômico e possui abrangência regional, pois age sobre a área de influência indireta. A tendência é a de se manter já que após a implantação haverá a fase de operação que manterá a média da renda e de tributos, Quadro 5.

\begin{tabular}{|c|c|c|c|}
\hline CRITÉRIO & $\begin{array}{c}\text { IMPACTO } \\
\text { POTENCIAL }\end{array}$ & \multirow{2}{*}{ MITIGAÇÃO/CONTROLE } & IMPACTO REAL \\
\hline Efeito & Positivo & & Positivo \\
\hline Intensidade & Alta & \multirow{4}{*}{$\begin{array}{c}\text { Inserção social - Apoio ao } \\
\text { município }\end{array}$} & Regional \\
\hline Abrangência & Regional & Relevante \\
\hline Significância & Relevante & & Direta \\
\hline Incidência & Direta & & Manter \\
\hline Tendência & Manter & & Reversível \\
\hline Reversibilidade & Reversível & & \\
& & & \\
& & &
\end{tabular}

Quadro 5 - Geração de renda e tributos

Fonte: MSS (2000)

A MSS (2000), prevê todavia, não somente o crescimento populacional da região, como também mazelas decorrentes de ocupação desordenada.

O impacto real nesta fase terá intensidade média, como colocado abaixo, com abrangência regional, pois age sobre a AII do meio socioeconômico, com significância marginal, e com tendência a se manter, considerando a aplicação dos planos de controle, de acordo com a MSS (2000). Será considerado irreversível em função do número de trabalhadores e famílias que poderão se fixar na região do empreendimento, após a etapa de implantação (Quadro 6).

\begin{tabular}{|c|c|c|c|}
\hline CRITÉRIO & $\begin{array}{c}\text { IMPACTO } \\
\text { POTENCIAL }\end{array}$ & MITIGAÇÃO/CONTROLE & IMPACTO REAL \\
\hline Efeito & Negativo & \multirow{7}{*}{$\begin{array}{l}\text { Inserção social - Apoio } \\
\text { ao município Inserção social - } \\
\text { Comunicação }\end{array}$} & Negativo \\
\hline Intensidade & Alta & & Média \\
\hline Abrangência & Regional & & Regional \\
\hline Significância & Crítica & & Marginal \\
\hline Incidência & Direta & & Direta \\
\hline Tendência & Progredir & & Manter \\
\hline Reversibilidade & Irreversível & & Irreversível \\
\hline
\end{tabular}

Quadro 6 - Aumento da população e ocupação desordenada Fonte: MSS (2000) 
Desse modo o impacto teria tendência de progredir com características irreversíveis, sobrecarga na infra-estrutura de serviços e equipamentos públicos, e incremento de problemas de saúde e segurança pública.

O impacto, pode ser considerado reversível tendo em vista a redução da população de trabalhadores após o pico de obra, e as eventuais melhorias conseguidas na infraestrutura das cidades, Quadro 7.

\begin{tabular}{|c|c|c|c|}
\hline CRITÉRIO & $\begin{array}{c}\text { IMPACTO } \\
\text { POTENCIAL }\end{array}$ & MITIGAÇÃO/CONTROLE & IMPACTO REAL \\
\hline Efeito & Negativo & \multirow{7}{*}{$\begin{array}{c}\text { Inserção social - Apoio ao } \\
\text { município } \\
\text { Inserção social - Comunicação }\end{array}$} & Negativo \\
\hline Intensidade & Alta & & Médio \\
\hline Abrangência & Regional & & Regional \\
\hline Significância & Crítica & & Marginal \\
\hline Incidência & Direta & & Direta \\
\hline Tendência & Progredir & & Manter \\
\hline Reversibilidade & Reversível & & Reversível \\
\hline
\end{tabular}

Quadro 7 - Sobrecarga na infra-estrutura de serviços e equipamentos públicos Fonte: MSS (2000)

Segundo a MSS (2000), este impacto prognosticado tem relação com os anteriores já descritos e possui o mesmo caráter potencial. O impacto potencial estaria vinculado ao grande afluxo de trabalhadores vindos de fora e de migrantes que poderiam ser atraídos pelo empreendimento proposto. Ocorreria desta forma, um aumento da probabilidade de surgimento de algum problema de saúde pública devido à introdução de algum tipo de doença, ou manifestação epidêmica de alguma outra já existente, e mesmo aumento de casos e da propagação de doenças sexualmente transmissíveis.

Além dos riscos à saúde pública, um processo abrupto de povoamento na área de influência poderia ainda demandar serviços da segurança pública, atualmente despreparada e insuficiente para conter possíveis manifestações agressivas à integridade do cidadão, provenientes de distúrbios sociais.

Nestas situações o impacto ambiental teria intensidade alta, já que estaria acima da capacidade de absorção do meio. A abrangência do impacto é regional pois age sobre a socioeconomia a da AII, e desta forma a significância seria crítica, com tendências a progredir, porém de caráter reversível. 
De acordo com a MSS (2000), não se prevê um aumento das populações num nível acima da capacidade de absorção do meio, e considerando ainda a realização de controle de doenças endêmicas da região para os trabalhadores a serem admitidos e a implementação de estruturas para controle sanitário, tanto na obra quanto no alojamento, o impacto real será considerado como de intensidade média, já que é sensível, mas assimilável pelo meio, e com abrangência regional. Assim sendo a significância será marginal, já que tem intensidade média mas está restrito a socioeconomia da área AII. A tendência do impacto é de se manter em função da aplicação dos programas de mitigação (Quadro 8).

\begin{tabular}{|c|c|c|c|}
\hline CRITÉRIO & $\begin{array}{c}\text { IMPACTO } \\
\text { POTENCIAL }\end{array}$ & MITIGAÇÃO/CONTROLE & $\begin{array}{l}\text { IMPACTO } \\
\text { REAL }\end{array}$ \\
\hline Efeito & Negativo & \multirow{7}{*}{$\begin{array}{c}\text { Controle nosológico } \\
\text { Inserção social - Apoio ao } \\
\text { município } \\
\text { nserção social - Comunicação }\end{array}$} & Negativo \\
\hline Intensidade & Alta & & Médio \\
\hline Abrangência & Regional & & Regional \\
\hline Significância & Crítica & & Marginal \\
\hline Incidência & Direta & & Direta \\
\hline Tendência & Progredir & & Manter \\
\hline Reversibilidade & Reversivel & & Reversível \\
\hline
\end{tabular}

Quadro 8 - Incrementos de problemas de saúde e segurança pública Fonte: MSS (2000)

Como efeito positivo, entretanto, a MSS (2000), sugere que ocorrerá com o melhoramento na infra-estrutura rodoviária, haverá estímulo à produção agropecuária $\mathrm{e}$ valorização das terras marginais à rodovia.

Este impacto no Quadro 9 é classificado como positivo, com intensidade alta, de acordo com a MSS (2000), já que será capaz de modificar de forma relevante o ambiente em estudo, possui abrangência regional, pois age sobre a AII e a área de entorno do empreendimento. Desta forma possui significância relevante, com tendência de progredir, já que após a abertura da estrada proporcionará oportunidades de negócios e de melhorias mesmo cessado a fase de obras. $O$ impacto pode ainda ser caracterizado como irreversível, pois o meio socioeconômico local não mais retornará à condição anterior, com um nível de beneficios maior que o anterior. 


\begin{tabular}{|c|c|c|c|}
\hline CRITÉRIO & $\begin{array}{c}\text { IMPACTO } \\
\text { POTENCIAL }\end{array}$ & MITIGAÇÃO/CONTROLE & IMPACTO REAL \\
\hline Efeito & Positivo & \multirow{7}{*}{ Inserção social } & Positivo \\
\hline Intensidade & Alta & & Alta \\
\hline Abrangência & Regional & & Regional \\
\hline Significância & Relevante & & Relevante \\
\hline Incidência & Direta & & Direta \\
\hline Tendência & Progredir & & Progredir \\
\hline Reversibilidade & Irreversível & & Irreversível \\
\hline
\end{tabular}

Quadro 9 - Melhoramentos na infra-estrutura rodoviária

Fonte: MSS (2000)

Segundo a MSS (2000), o empreendimento proposto teve que passar por um processo de relocação involuntária na medida em que torna-se impossível conciliar sua implantação à permanência dos remanescentes dos pequenos aglomerados populacionais ou de benfeitorias em áreas próximas, nas quais serão implantadas e abertas as minas e áreas de apoio.

A abertura das frentes de lavra previstas e demais estruturas de apoio à produção encontram-se em áreas onde atualmente situam-se os remanescentes dos povoados Vila do Sossego e Sequeirinho. Desta forma tornou-se necessário a relocação dos remanescentes destas comunidades.

Considerando-se a possibilidade da falta de adaptação das populações com a situação nova criada pelo processo de Relocação, o impacto potencial pode ser considerado negativo e de intensidade alta, estando acima da capacidade de absorção do meio. A aplicação do Plano de Relocação, como forma de mitigação deste impacto, pode reverter o efeito deste, conforme a (MSS, 2000).

Partindo-se do pressuposto de que grande parte da população destas comunidades já saiu da área em busca de condições melhores ou de outras oportunidades e que os remanescentes serão auxiliados pelo Plano de Relocação para alcançar condições satisfatórias, a intensidade do impacto pode chegar a ser baixa com significância desprezível, com total adaptação das populações envolvidas.

No entanto, em razão da falta de elementos conclusivos, até o momento da elaboração deste documento, já que se trata de ação futura, adota-se a pior hipótese e, pela impossibilidade de afirmar que haverá a adaptação completa das populações 
envolvidas, o efeito, na classificação de impacto real continua como negativo e com intensidade média (Quadro 10), sendo assimilável pelo meio, segundo (MSS, 2000).

\begin{tabular}{|c|c|c|c|}
\hline CRITÉRIO & $\begin{array}{c}\text { IMPACTO } \\
\text { POTENCIAL }\end{array}$ & \multirow{2}{*}{ MITIGAÇÃO/CONTROLE } & $\begin{array}{c}\text { IMPACTO } \\
\text { REAL }\end{array}$ \\
\hline Efeito & Negativo & \multirow{4}{*}{ Plano de relocação } & Negativo \\
\hline Intensidade & Alta & & Média \\
\hline Abrangência & Local & & Local \\
\hline Significância & Crítica & & Marginal \\
\hline Incidência & Direta & & Direta \\
\hline Tendência & Manter & & Manter \\
\hline Reversibilidade & Ireversível & & Irreversível \\
\hline
\end{tabular}

Quadro 10 - Relocação involuntária

Fonte: MSS (2000)

O Quadro-resumo 11 apontam para os impactos negativos e positivos oriundos da fase de implantação do projeto.

\begin{tabular}{|c|c|c|c|c|c|c|c|c|}
\hline \multicolumn{6}{|c|}{ MINERAÇ̃̃O SERRA DO SOSSEGO - ETAPA DE IMPLANTAĈ̃O } \\
\hline $\begin{array}{c}\text { Aspecto/ } \\
\text { Impacto Ambiental }\end{array}$ & $\begin{array}{c}\text { Intensi- } \\
\text { dade }\end{array}$ & $\begin{array}{c}\text { Abran- } \\
\text { gência }\end{array}$ & $\begin{array}{c}\text { Signifi- } \\
\text { cância }\end{array}$ & $\begin{array}{c}\text { Incidên- } \\
\text { cia }\end{array}$ & $\begin{array}{c}\text { Tendên- } \\
\text { cia }\end{array}$ & $\begin{array}{c}\text { Reversibi- } \\
\text { lidade }\end{array}$ & Efeito \\
\hline $\begin{array}{c}\text { Criação de empregos } \\
\begin{array}{c}\text { Geração de renda e } \\
\text { tributos }\end{array}\end{array}$ Alta & Regional & Crítica & Direta & Regredir & Reversível & Positivo \\
\hline $\begin{array}{c}\text { Aumento da } \\
\text { população e } \\
\text { ocupação } \\
\text { desordenada }\end{array}$ & Média & Regional & Marginal & Direta & Manter & Irreversível & Negativo \\
\hline $\begin{array}{c}\text { Sobrecarga na infra- } \\
\text { estrutura de serviços } \\
\text { e equipamentos } \\
\text { públicos }\end{array}$ & Média & Regional & Marginal & Direta & Manter & Reversível & Negativo \\
\hline $\begin{array}{c}\text { Incremento de } \\
\text { problemas de saúde } \\
\text { e segurança públicas }\end{array}$ & Média & Regional & Marginal & Direta & Manter & Reversível & Negativo \\
\hline $\begin{array}{c}\text { Melhoramentos na } \\
\text { infra-estrutura } \\
\text { rodoviária }\end{array}$ & Alta & Regional & Relevant & e & Direta & Progredir & Irreversível & Positivo \\
\hline $\begin{array}{c}\text { Relocação } \\
\text { involuntária }\end{array}$ & Média & Local & Marginal & Direta & Manter & Irreversível & Negativo \\
\hline
\end{tabular}

Quadro 11 - Resumo da avaliação de impacto real na etapa de implantação da Mineração Serra do Sossego

Fonte: MSS (2000) 


\subsection{Etapa de operação}

A MSS (2000), descreve e avalia os impactos ambientais decorrentes da Etapa de Operação do empreendimento.

A respeito dos impactos sobre o meio antrópico em decorrência da operacionalização do Projeto, há previsão de criação de 667 empregos diretos e 1.500 indiretos, mão-de-obra essa recrutada na própria região, com efeito positivo de inserção social.

Prevê-se que partes dos empregos diretos requeiram mão-de-obra qualificada. Parte desta mão-de-obra poderá ser contratada em Parauapebas e Canaã dos Carajás, que já dispõe de um contingente de trabalhadores com experiência em atividades mineiras. Outros profissionais provavelmente serão contratados em outros centros, que não pertencem à área de influência antrópica.

O impacto positivo possui intensidade alta, pois é capaz de modificar de forma importante o ambiente, possui abrangência regional já que age na área de influência indireta, podendo até mesmo extrapola-la. A significância é relevante com tendência de se manter durante a vida do empreendimento, com características de reversibilidade ao fim da operação, já que estes postos de trabalho podem ser perdidos (Quadro 12).

\begin{tabular}{|c|c|c|c|}
\hline CRITÉRIO & $\begin{array}{c}\text { IMPACTO } \\
\text { POTENCIAL }\end{array}$ & MITIGAÇÃO/CONTROLE & $\begin{array}{l}\text { IMPACTO } \\
\text { REAL }\end{array}$ \\
\hline Efeito & Positivo & \multirow{7}{*}{ Inserção social } & Positivo \\
\hline Intensidade & Alta & & Alta \\
\hline Abrangência & Regional & & Regional \\
\hline Significância & Relevante & & Relevante \\
\hline Incidência & Direta & & Direta \\
\hline Tendência & Manter & & Manter \\
\hline Reversibilidade & Reversivel & & Reversível \\
\hline
\end{tabular}

Quadro 12 - Criação de empregos

Fonte: MSS (2000)

Dessa maneira, haverá incremento significativo na geração de renda e tributos, impacto esse de alta intensidade e incidência direta.

Com relação à arrecadação tributária, o empreendimento favorecerá o incremento nas receitas pública nos níveis municipal, (em Canaã dos Carajás), Estadual e Federal. 
Este impacto tem intensidade alta, já que da mesma forma que o anterior, pode modificar de forma importante o ambiente. Possui abrangência regional, já que atua na área de influência indireta, podendo extrapolá-la. A significância é relevante com tendência a se manter durante a vida do empreendimento, com característica de reversão, no fechamento (Quadro 13).

\begin{tabular}{|c|c|c|c|}
\hline CRITÉrIO & $\begin{array}{c}\text { IMPACTO } \\
\text { POTENCIAL }\end{array}$ & MITIGAÇÃO/CONTROLE & $\begin{array}{c}\text { IMPACTO } \\
\text { REAL }\end{array}$ \\
\hline Efeito & Positivo & & Positivo \\
\hline Intensidade & Alta & \multirow{4}{*}{$\begin{array}{c}\text { Inserção social } \\
\text { Plano de fechamento }\end{array}$} & Alta \\
\hline Abrangência & Regional & & Regional \\
\hline Significância & Relevante & & Direta \\
\hline Incidência & Direta & & Manter \\
\hline Tendência & Manter & & Reversível \\
\hline Reversibilidade & Reversível & & \\
& & & \\
& & &
\end{tabular}

Quadro 13 - Geração de renda e tributos

Fonte: MSS (2000)

A população da região será, ainda, beneficiada com a construção de uma rodovia, de relevante significância para o melhoramento na comunicação regional; os riscos de acidentes e emissão de ruídos e vibrações face ao trânsito pesado de caminhões serão mitigados e controlados por plano emergêncial e pela educação para o trânsito, conforme o estudo de impacto.

Um impacto positivo da operação do empreendimento é o papel que a rodovia terá no processo de integração da população rural das proximidades da área de sua intervenção com a região urbana dos municípios da área de influência do empreendimento.

O impacto possui intensidade alta pois pode modificar de forma importante o ambiente. Possui abrangência regional, já que atua na área de influência indireta. A significância é relevante com tendência a se manter durante a vida do empreendimento, com características irreversíveis, já que no fechamento a estrada permanecerá (Quadro 14). 


\begin{tabular}{|c|c|c|c|}
\hline CRITÉRIO & $\begin{array}{c}\text { IMPACTO } \\
\text { POTENCIAL }\end{array}$ & MITIGAÇÃO/CONTROLE & $\begin{array}{c}\text { IMPACTO } \\
\text { REAL }\end{array}$ \\
\hline Efeito & Positivo & \multirow{4}{*}{ Inserção social } & Positivo \\
\hline Intensidade & Alta & & Alta \\
\hline Abrangência & Regional & & Regional \\
\hline Significância & Relevante & & Relevante \\
\hline Incidência & Direta & & Direta \\
\hline Tendência & Manter & & Manter \\
\hline Reversibilidade & Irreversível & & Irreversível \\
\hline
\end{tabular}

Quadro 14 - Garantia de acesso em virtude da rodovia

Fonte: MSS (2000)

De acordo com a MSS (2000), com relação ao impacto de incômodos e riscos relacionados à operação da rodovia, o impacto real será negativo, com intensidade média, já que será sensível, com conseqüências pouco notáveis e após controle e aplicação de medidas de compensação, prevê-se que esteja dentro de parâmetros legais de emissão de ruído. Possui abrangência regional, pois age sobre a AII, e significância marginal. A tendência é de se manter ao longo da etapa de operação, com caráter reversível quando aplicadas às medidas de controle (Quadro 15).

\begin{tabular}{|c|c|c|c|}
\hline CRITÉRIO & $\begin{array}{c}\text { IMPACTO } \\
\text { POTENCIAL }\end{array}$ & MITIGAÇÃO/CONTROLE & IMPACTO REAL \\
\hline Efeito & Negativo & \multirow{7}{*}{$\begin{array}{l}\text { Plano de emergência } \\
\text { Controle de manutenção de } \\
\text { veículos e equipamentos } \\
\text { Inserção social - Educação e } \\
\text { informação para o trânsito }\end{array}$} & Negativo \\
\hline Intensidade & Média & & Média \\
\hline Abrangência & Regional & & Regional \\
\hline Significância & Marginal & & Marginal \\
\hline Incidência & Direta & & Direta \\
\hline Tendência & Manter & & Manter \\
\hline Reversibilidade & Reversível & & Reversível \\
\hline
\end{tabular}

Quadro 15 - Impacto de incômodos e riscos relacionados à operação da rodovia Fonte: MSS (2000)

A MSS (2000), reputa positivo o impacto da oferta de cobre pelo empreendimento, atendendo demanda dos mercados interno e externo, implicando, inclusive, no alavancamento de negócios minerais ou alternativas econômicas na região, com incidência direta.

O impacto é positivo, com intensidade média, já que é sensível, podendo não gerar modificações estruturais no ambiente, já que possui abrangência global, extrapolando a 
área de influência indireta. Os aspectos do mercado nacional e internacional de cobre extrapolam a análise do diagnóstico socioeconômico deste documento. A significância do impacto é relevante pela sua abrangência (Quadro 16).

\begin{tabular}{|c|c|c|c|}
\hline CRITÉRIO & $\begin{array}{c}\text { IMPACTO } \\
\text { POTENCIAL }\end{array}$ & \multirow{2}{*}{ MITIGAÇÃO/CONTROLE } & $\begin{array}{c}\text { IMPACTO } \\
\text { REAL }\end{array}$ \\
\hline Efeito & Positivo & \multirow{5}{*}{} & Positivo \\
\hline Intensidade & Media & \multirow{5}{*}{} & Media \\
\hline Abrangência & Global & \multirow{5}{*}{ Global } \\
\hline Significância & Relevante & & Relevante \\
\hline Incidência & Indireta & & Indireta \\
\hline Tendência & Manter & & Manter \\
\hline Reversibilidade & Reversível & & Reversível \\
\hline
\end{tabular}

Quadro 16 - Oferta de cobre no mercado nacional e internacional Fonte: MSS (2000)

Pode-se citar como impacto positivo à atenção política despertada para a área em função do empreendimento, com provável aumento de investimentos particulares e de infra-estrutura, tanto na área urbana, quanto rural dos municípios de Parauapebas e Canaã dos Carajás (MSS, 2000).

Este impacto potencial terá intensidade média, com conseqüências pouco notáveis, podendo vir a modificar de forma importante o ambiente, caso o Projeto Sossego propicie um ambiente de desenvolvimento de outros possíveis empreendimentos minerais na área, ou mesmo outras atividades econômicas alternativas. A aplicação do plano de inserção social pode contribuir para este processo (Anexo 3). Neste caso a intensidade do impacto passa a alta, com significância relevante (Quadro 17). 


\begin{tabular}{|c|c|c|c|}
\hline CRITÉRIO & $\begin{array}{c}\text { IMPACTO } \\
\text { POTENCIAL }\end{array}$ & MITIGAÇÃO/CONTROLE & $\begin{array}{c}\text { IMPACTO } \\
\text { REAL }\end{array}$ \\
\hline Efeito & Positivo & \multirow{4}{*}{$\begin{array}{c}\text { Inserção social - Apoio ao } \\
\text { município }\end{array}$} & Positivo \\
\hline Intensidade & Média & & Alta \\
\hline Abrangência & Regional & & Relevante \\
\hline Significância & Marginal & & Direta \\
\hline Incidência & Direta & & Manter \\
\hline Tendência & Manter & & Reversível \\
\hline Reversibilidade & Reversível & & \\
& & & \\
& & &
\end{tabular}

Quadro 17 - Incremento de negócios e da importância política da área Fonte: MSS (2000)

A respeito dos problemas oriundos de ocupação desordenada, e a ineficiência dos setores saúde e segurança, esses serão mitigados através dos programas de controle nosológico de inserção social (Anexo 3).

O impacto potencial tem relação direta com o exposto para a avaliação de impacto na fase de implantação, podendo apresentar intensidade alta, caso o aumento da população fosse acentuado, podendo pressionar os núcleos urbanos da All, que como visto não possuem infra-estrutura adequada que comporte aumentos populacionais, pressionando também os serviços públicos de saúde, educação, saneamento, e segurança. Segundo (MSS, 2000), não se prevê um aumento considerável destas populações, como colocado acima, este impacto passa a uma classificação de intensidade média, com significância marginal. Deve-se considerar ainda a aplicação das medidas de mitigação e controle, como forma de atenuar o impacto (Quadro 18).

\begin{tabular}{|c|c|c|c|}
\hline CRITÉRIO & $\begin{array}{c}\text { IMPACTO } \\
\text { POTENCIAL }\end{array}$ & MITIGAÇÃO/CONTROLE & $\begin{array}{c}\text { IMPACTO } \\
\text { REAL }\end{array}$ \\
\hline Efeito & Negativo & \multirow{7}{*}{$\begin{array}{c}\text { Controle nosológico } \\
\text { Inserção social - Apoio ao } \\
\text { município } \\
\text { Iserção social - Comunicação }\end{array}$} & Negativo \\
\hline Intensidade & Alta & & Média \\
\hline Abrangência & Regional & & Regional \\
\hline Significância & Crítica & & Marginal \\
\hline Incidência & Direta & & Direta \\
\hline Tendência & Manter & & Manter \\
\hline Reversibilidade & Reversível & & Reversível \\
\hline
\end{tabular}

Quadro 18 - Ocupação desordenada, incremento de problemas de saúde e segurança Fonte: MSS (2000) 
Os quadros-resumos apontam para os impactos negativos e positivos oriundos da operação do projeto, de acordo com a (MSS, 2000).

\begin{tabular}{|c|c|c|c|c|c|c|c|c|}
\hline \multicolumn{7}{|c|}{$\begin{array}{c}\text { MINERAÇÕO SERRA DO SOSSEGO } \\
\text { Ambiental }\end{array}$} \\
\hline $\begin{array}{c}\text { Aspecto/Impacto } \\
\text { siden- }\end{array}$ & $\begin{array}{c}\text { Abran- } \\
\text { gência }\end{array}$ & $\begin{array}{c}\text { Signifi- } \\
\text { cância }\end{array}$ & $\begin{array}{c}\text { Incidên- } \\
\text { cia }\end{array}$ & $\begin{array}{c}\text { Tendên- } \\
\text { cia }\end{array}$ & $\begin{array}{c}\text { Reversibili- } \\
\text { dade }\end{array}$ & Efeito \\
\hline Criação de empregos & Alta & Regional & Relevante & Direta & Manter & Reversível & Positivo \\
\hline $\begin{array}{c}\text { Geração de renda e } \\
\text { tributos }\end{array}$ & Alta & Regional & Relevante & Direta & Manter & Reversível & Positivo \\
\hline $\begin{array}{c}\text { Garantia de acesso em } \\
\text { virtude da rodovia }\end{array}$ & Alta & Regional & Relevante & Direta & Manter & Irreversível & Positivo \\
\hline $\begin{array}{c}\text { Incômodos e riscos } \\
\text { relacionados à } \\
\text { operação da rodovia }\end{array}$ & Média & Regional & Marginal & Direta & Manter & Reversível & Negativo \\
\hline $\begin{array}{c}\text { Oferta de cobre no } \\
\text { mercado nacional e } \\
\text { internacional }\end{array}$ & Média & Global & Relevante & Direta & Manter & Reversível & Positivo \\
\hline $\begin{array}{c}\text { Incremento de } \\
\text { negócios e da } \\
\text { importância política da } \\
\text { área }\end{array}$ & Alta & Regional & Relevante & Direta & Manter & Reversível & Positivo \\
\hline $\begin{array}{c}\text { Ocupação } \\
\text { desordenada, } \\
\text { incremento de } \\
\text { problemas de saúde e } \\
\text { segurança }\end{array}$ & Média & Regional & Marginal & Direta & Manter & Irreversível & Negativo \\
\hline
\end{tabular}

Quadro 19 - Resumo de avaliação de impacto real na etapa de operação Mineração Serra do Sossego

Fonte: MSS (2000)

\subsection{Etapa de fechamento}

O EIA também avalia os impactos ambientais decorrentes da Etapa de Fechamento do Projeto, adotando a mesma metodologia da Etapa de Implantação e da Etapa de Operação.

Nessa fase do empreendimento haverá a eliminação do quadro de emprego, que será de 667 empregos diretos. Pode-se prever a eliminação de cerca de 400 empregos indiretos, remanescentes dos 1.500 iniciais, associados à prestação de serviços diversos tais como segurança patrimonial, restaurante, transporte de concentrado, limpeza e outros. Deve-se ressaltar que os profissionais qualificados durante a fase operacional poderão realizar outras atividades, desenvolvendo novas vocações, como uma tendência já hoje percebida no mercado de trabalho. Para tal, prevê-se um programa de relocação 
de mão-de-obra (Anexo 3). A aplicação deste e dos demais programas do plano de fechamento (Anexo 3) poderá atenuar a intensidade deste impacto, tornando-o assimilável na área de influência do empreendimento (Quadro 20).

\begin{tabular}{|c|c|c|c|}
\hline CRITÉRIO & $\begin{array}{c}\text { IMPACTO } \\
\text { POTENCIAL } \\
\end{array}$ & MITIGAÇÃO/CONTROLE & $\begin{array}{c}\text { IMPACTO } \\
\text { REAL } \\
\end{array}$ \\
\hline Efeito & Negativo & \multirow{7}{*}{$\begin{array}{l}\text { Plano de fechamento } \\
\text { (programas de diversificação } \\
\text { econômica do município e de } \\
\text { relocação de mão de obra) }\end{array}$} & Negativo \\
\hline Intensidade & Alta & & Média \\
\hline Abrangência & Regional & & Regional \\
\hline Significância & Crítica & & Marginal \\
\hline Incidência & Direta & & Direta \\
\hline Tendência & Manter & & Manter \\
\hline Reversibilidade & Irreversível & & Irreversível \\
\hline
\end{tabular}

Quadro 20 - Eliminação de empregos

Fonte: MSS (2000)

Com o seu fechamento, o empreendimento deixará de proporcionar um significativo fator na renda regional a partir da massa salarial que era distribuída e gasta nos municípios da área de influência, além da eliminação dos recolhimentos de impostos de diversas naturezas (IR, ICMS, ISS, CFEM etc.).

Com relação à arrecadação tributária, o empreendimento deixará de representar uma importante fonte nas receitas pública a nível municipal, em Canaã dos Carajás, Estadual e Federal.

Da mesma forma que no item anterior, a aplicação dos programas que faz parte do plano de fechamento (Anexo 3) (programas de diversificação econômica do município e de relocação de mão-de-obra) poderá atenuar a intensidade deste impacto, tornando-o assimilável na área de influência do empreendimento (Quadro 21).

\begin{tabular}{|c|c|c|c|}
\hline CRITÉRIO & $\begin{array}{c}\text { IMPACTO } \\
\text { POTENCIAL }\end{array}$ & MITIGAÇÃO/CONTROLE & $\begin{array}{c}\text { IMPACTO } \\
\text { REAL }\end{array}$ \\
\hline Efeito & Negativo & \multirow{7}{*}{$\begin{array}{l}\text { Plano de fechamento } \\
\text { (programas de diversificação } \\
\text { econômica do município e de } \\
\text { relocação de mão de obra) }\end{array}$} & Negativo \\
\hline Intensidade & Alta & & Média \\
\hline Abrangência & Regional & & Regional \\
\hline Significância & Crítica & & Marginal \\
\hline Incidência & Direta & & Direta \\
\hline Tendência & Manter & & Manter \\
\hline Reversibilidade & Irreversível & & Irreversível \\
\hline
\end{tabular}

Quadro 21 - Redução de renda e tributos

Fonte: MSS (2000) 
Segundo a (MSS, 2000) tendo em vista o fechamento do empreendimento, grande parte do tráfego pesado deixará de circular na mesma, eliminando uma série de riscos e incômodos à população residente ao longo de seu traçado proposto (Quadro 22).

\begin{tabular}{|c|c|c|c|}
\hline CRITÉRIO & $\begin{array}{c}\text { IMPACTO } \\
\text { POTENCIAL }\end{array}$ & MITIGAÇÃO/CONTROLE & $\begin{array}{c}\text { IMPACTO } \\
\text { REAL }\end{array}$ \\
\hline Efeito & Positivo & \multirow{7}{*}{-} & Positivo \\
\hline Intensidade & Media & & Media \\
\hline Abrangência & Regional & & Regional \\
\hline Significância & Marginal & & Marginal \\
\hline Incidencia & Direta & & Direta \\
\hline Tendência & Manter & & Manter \\
\hline Reversibilidade & Reversível & & Reversível \\
\hline
\end{tabular}

Quadro 22 - Redução dos incômodos e riscos relacionados à operação da rodovia Fonte: MSS (2000)

O fechamento do empreendimento poderá implicar na redução da oferta de concentrado no mercado nacional e internacional, e na redução das exportações brasileiras deste insumo, interferindo negativamente na Balança Comercial do Brasil. No entanto, dada à dificuldade de se avaliar, à época de elaboração deste documento, a condição futura de mercado, com possibilidades de abertura de outras minas, no plano internacional ou nacional, e conseqüente alteração deste quadro, a avaliação de impacto real está sendo colocada como a pior hipótese, de mesmas características do impacto potencial.

Ressalta-se que programas de prospecção mineral, já em curso na região, poderão reverter este impacto (Quadro 23).

\begin{tabular}{|c|c|c|c|}
\hline CRITÉRIO & $\begin{array}{c}\text { IMPACTO } \\
\text { POTENCIAL }\end{array}$ & \multirow{2}{*}{ MITIGAÇÃO/CONTROLE } & $\begin{array}{c}\text { IMPACTO } \\
\text { REAL }\end{array}$ \\
\hline Efeito & Negativo & & Negativo \\
\hline Intensidade & Média & \multirow{5}{*}{} & Média \\
\hline Abrangência & Global & \multirow{5}{*}{} & Global \\
\hline Significância & Crítica & & Crítica \\
\hline Incidência & Direta & & Direta \\
\hline Tendência & Manter & & Manter \\
\hline Reversibilidade & Irreversível & & Irreversível \\
\hline
\end{tabular}

Quadro 23 - Redução na oferta de cobre no mercado nacional e internacional Fonte: MSS (2000) 
O fechamento do empreendimento pode potencialmente levar à estagnação econômica na área, com redução dos negócios e fechamento de pequenas empresas.

Da mesma forma que nos itens referentes à geração de empregos e de renda, a aplicação dos programas do plano de fechamento poderá atenuar a intensidade deste impacto, tornando-o assimilável na área de influência do empreendimento (Quadro 24).

\begin{tabular}{|c|c|c|c|}
\hline CRITÉRIO & $\begin{array}{c}\text { IMPACTO } \\
\text { POTENCIAL }\end{array}$ & MITIGAÇÃO/CONTROLE & $\begin{array}{c}\text { IMPACTO } \\
\text { REAL }\end{array}$ \\
\hline Efeito & Negativo & \multirow{7}{*}{$\begin{array}{l}\text { Plano de fechamento } \\
\text { (programas de diversificação } \\
\text { econômica do município e de } \\
\text { relocação de mão de obra) }\end{array}$} & Negativo \\
\hline Intensidade & Alta & & Média \\
\hline Abrangência & Regional & & Regional \\
\hline Significância & Crítica & & Marginal \\
\hline Incidência & Direta & & Direta \\
\hline Tendência & Manter & & Manter \\
\hline Reversibilidade & Irreversível & & Irreversível \\
\hline
\end{tabular}

Quadro 24 - Redução de negócios na área Fonte: MSS (2000)

De acordo com a MSS (2000), quadros-resumos $(7.1 .11,7.2 .19,7.3 .25)$ apontam a viabilidade ambiental do empreendimento, visto que a análise custo/benefício ambiental aponta a superioridade dos benefícios ambientais (impactos positivos) em relação aos custos ambientais (impactos negativos).

Ainda de acordo com os quadros resumos, estes indicam que os impactos negativos reais gerados pelo empreendimento, em suas três fases, encontram-se dentro das condições de significância desprezível à marginal, refletindo intensidades baixa e média. Somente um impacto negativo real, referente à redução do cobre no mercado na fase de fechamento, foi enquadrado como crítico, após ter cumprido o efeito positivo no que tange no aspecto socieconômico.

A análise custo/ambiental do empreendimento indica uma relação em que os benefícios ambientais, representados pelos impactos positivos, sejam maiores que os custos ambientais, representados pelos impactos negativos, conforme (Quadro 25). A realização do empreendimento apresenta viabilidade ambiental de acordo com a (MSS, 2000). 


\begin{tabular}{|c|c|c|c|c|c|c|c|}
\hline $\begin{array}{c}\text { Aspecto/Impacto } \\
\text { ambiental }\end{array}$ & $\begin{array}{c}\text { Inten- } \\
\text { sidade }\end{array}$ & $\begin{array}{c}\text { Abran- } \\
\text { gência }\end{array}$ & $\begin{array}{c}\text { Signifi- } \\
\text { cância }\end{array}$ & $\begin{array}{c}\text { Inci- } \\
\text { dência }\end{array}$ & $\begin{array}{c}\text { Ten- } \\
\text { dência }\end{array}$ & $\begin{array}{c}\text { Reversibi- } \\
\text { lidade }\end{array}$ & Efeito \\
\hline $\begin{array}{c}\text { Eliminação de } \\
\text { empregos }\end{array}$ & Média & Regional & Marginal & Direta & Manter & Reversível & Negativo \\
\hline $\begin{array}{c}\text { Redução de renda e } \\
\text { tributos }\end{array}$ & Média & Regional & Marginal & Direta & Manter & Reversível & Negativo \\
\hline $\begin{array}{c}\text { Redução de incômodos } \\
\text { e riscos relacionados à } \\
\text { operação da rodovia }\end{array}$ & Média & Regional & Marginal & Direta & Manter & Reversível & Positivo \\
\hline $\begin{array}{c}\text { Redução da oferta de } \\
\text { cobre no mercado } \\
\text { nacional e internacional }\end{array}$ & Média & Global & Crítica & Direta & Manter & Reversível & Negativo \\
\hline $\begin{array}{c}\text { Redução de negócios } \\
\text { na área }\end{array}$ & Média & Regional & Marginal & Direta & Manter & Reversível & Negativo \\
\hline
\end{tabular}

Quadro 25 - Resumo de avaliação de impacto real na etapa de desativação Mineração Serra do Sossego

Fonte: MSS (2000)

\subsection{Programas de mitigação e monitoramento}

Os Quadros 26, 27, 28 que se seguem apresentam a relação entre os impactos prognosticados e as medidas mitigadoras para os mesmos, que são apresentadas em três níveis: minimização, que corresponde a ações que visam reduzir ou eliminar impactos; reabilitação, que corresponde a ações que visam corrigir impactos não minimizáveis; compensação, que são ações no sentido de compensar impactos que não podem ser eliminados, reduzidos ou reabilitados.

Além destas medidas, são consideradas também as medidas de incremento aos impactos positivos, e os programas de monitoramento, que tem o objetivo de aferir a eficácia dos programas de mitigação adotados.

A seguir, serão descritas, de forma sintética, os programas de mitigação e monitoramento para os impactos prognosticados. 


\begin{tabular}{|c|c|c|c|c|}
\hline $\begin{array}{c}\text { Impacto } \\
\text { Prognosticado }\end{array}$ & Minimização & Reabilitação & $\begin{array}{c}\text { Compensação e } \\
\text { Intensificação dos } \\
\text { Impactos positivos }\end{array}$ & Monitoramento \\
\hline $\begin{array}{c}\text { Monitoramento } \\
\text { Socioeconômico }\end{array}$ & - & - & $\begin{array}{c}\text { Inserção social - } \\
\text { Priorização da } \\
\text { população local }\end{array}$ & - \\
\hline $\begin{array}{c}\text { Monitoramento } \\
\text { Socioeconômico }\end{array}$ & - & - & $\begin{array}{c}\text { Inserção social - } \\
\text { Apoio ao município }\end{array}$ & - \\
\hline $\begin{array}{c}\text { Monitoramento } \\
\text { Socioeconômico }\end{array}$ & - & - & $\begin{array}{c}\text { Inserção social - } \\
\text { Comunicação social }\end{array}$ & - \\
\hline $\begin{array}{c}\text { Monitoramento de } \\
\text { doenças endêmicas }\end{array}$ & $\begin{array}{c}\text { Controle } \\
\text { nosológico }\end{array}$ & - & $\begin{array}{c}\text { Inserção social - } \\
\text { Comunicação social }\end{array}$ & - \\
\hline $\begin{array}{c}\text { Monitoramento } \\
\text { Socioeconômico }\end{array}$ & $\begin{array}{c}\text { Plano de } \\
\text { relocação }\end{array}$ & - & Inserção social & - \\
\hline
\end{tabular}

Quadro 26 - Programas de mitigação e monitoramento: etapa de implantação Fonte: MSS (2000)

\begin{tabular}{|c|c|c|c|c|}
\hline $\begin{array}{c}\text { Impacto } \\
\text { Prognosticado }\end{array}$ & Minimização & Reabilitação & $\begin{array}{l}\text { Compensação e } \\
\text { Intensificação dos } \\
\text { Impactos positivos }\end{array}$ & Monitoramento \\
\hline Criação de empregos & - & - & $\begin{array}{l}\text { Inserção social - } \\
\text { Priorização da } \\
\text { população local }\end{array}$ & $\begin{array}{l}\text { Monitoramento } \\
\text { socioeconômico }\end{array}$ \\
\hline $\begin{array}{c}\text { Geração de renda e } \\
\text { tributos }\end{array}$ & - & - & $\begin{array}{c}\text { Inserção social - Apoio } \\
\text { ao município }\end{array}$ & $\begin{array}{l}\text { Monitoramento } \\
\text { socioeconômico }\end{array}$ \\
\hline $\begin{array}{l}\text { Garantia de acesso em } \\
\text { virtude da rodovia }\end{array}$ & - & - & Inserção social & - \\
\hline $\begin{array}{l}\text { Incômodos e riscos } \\
\text { relacionados à } \\
\text { operação da rodovia }\end{array}$ & - & - & $\begin{array}{c}\text { Inserção social - } \\
\begin{array}{c}\text { Educação e informação } \\
\text { para o trânsito }\end{array}\end{array}$ & $\begin{array}{l}\text { Registro de } \\
\text { acidentes }\end{array}$ \\
\hline $\begin{array}{l}\text { Oferta de cobre no } \\
\text { mercado nacional e } \\
\text { internacional }\end{array}$ & - & - & - & - \\
\hline $\begin{array}{c}\text { Ocupação } \\
\text { desordenada, } \\
\text { incremento de } \\
\text { problemas de saúde e } \\
\text { segurança }\end{array}$ & $\begin{array}{l}\text { Controle } \\
\text { nosológico }\end{array}$ & - & $\begin{array}{c}\text { Inserção social - Apoio } \\
\text { ao município } \\
\text { Inserção social - } \\
\text { Comunicação }\end{array}$ & $\begin{array}{c}\text { Monitoramento } \\
\text { socioeconômico } \\
\text { Monitoramento } \\
\text { de doenças } \\
\text { endêmicas } \\
\end{array}$ \\
\hline
\end{tabular}

Quadro 27 - Relação entre os impactos prognosticados e as medidas de mitigação propostas: Fonte: MSS (2000) etapa de operação 


\begin{tabular}{|c|c|r|r|r|}
\hline Impacto Prognosticado & Minimização & Reabilitação & $\begin{array}{c}\text { Compensação e } \\
\text { Intensificação dos } \\
\text { Impactos positivos }\end{array}$ & Monitoramento \\
\hline $\begin{array}{c}\text { Eliminação de empregos } \\
\text { Rechamento }\end{array}$ & $\begin{array}{c}\text { Plano de } \\
\text { feção de renda e } \\
\text { tributos }\end{array}$ & $\begin{array}{c}\text { Plano de } \\
\text { fechamento }\end{array}$ & - & $\begin{array}{r}\text { Monitoramento } \\
\text { Socioeconômico }\end{array}$ \\
\hline $\begin{array}{c}\text { Redução de incômodos } \\
\text { e riscos relacionados à } \\
\text { operação da rodovia }\end{array}$ & - & - & $-\begin{array}{c}\text { Monitoramento } \\
\text { socioeconômico }\end{array}$ \\
\hline $\begin{array}{c}\text { Redução da oferta de } \\
\text { cobre no mercado } \\
\text { nacional e internacional }\end{array}$ & - & - & $-\begin{array}{c}\text { Monitoramento } \\
\text { socioeconômico }\end{array}$ \\
\hline $\begin{array}{c}\text { Redução de negócios na } \\
\text { área }\end{array}$ & $\begin{array}{c}\text { Plano de } \\
\text { fechamento }\end{array}$ & - & $-\begin{array}{c}\text { Monitoramento } \\
\text { socioeconômico }\end{array}$ \\
\hline
\end{tabular}

Quadro 28 - Relação entre os impactos prognosticados e as medidas de mitigação propostas: etapa de desativação

Fonte: MSS (2000)

\subsection{Medidas de mitigação dos impactos}

No estudo da MSS (2000), várias medidas mitigadoras e compensatórias, foram apresentadas em função das alternativas locacionais, e dos parâmetros ambientais. Nesta fase do licenciamento prévio, o EIA/RIMA, apresentou apenas as diretrizes do que seria os Programas de Controle Ambiental.

Essas medidas serão implantadas visando principalmente o aproveitamento por parte das comunidades locais e regionais das novas condições criadas com a implantação dessas atividades.

As medidas mitigadoras e compensatórias são propostas para ressaltar as vantagens do empreendimento e reduzir os impactos causados.

Foram apresentadas as seguintes medidas mitigadoras relativas ao aspecto socioeconômico: Controle Nosológico, Plano de Relocação.

A seguir, são descritas as Medidas de Compensação, que foram objetos de detalhamento nos Programas de Controle Ambientais, relativos aos aspectos socioeconômicos no Programa de Inserção Social. 
Os planos de monitoramento do empreendimento foram detalhados nos Plano de Controle Ambiental, cujos dados deverão ser usados para melhoria dos programas de controle ou para tomada de ação corretiva, caso seja necessário.

A seguir são apresentados os Planos de Monitoramento relativos aos aspectos socioeconômicos: Monitoramento Socioeconômico e Monitoramento de Doenças Endêmicas.

O termo fechamento da mina é internacionalmente aceito como sendo definição das ações necessárias que devem ser tomadas para garantir a estabilidade química, física e biológica da área de uma determinada mina ao fim de sua vida útil. O Plano de Fechamento, portanto constitui-se num documento básico de planejamento ambiental, cujo conceito deve ser estendido para o âmbito socioeconômico, com os seguintes objetivos básicos:

a) estabelecer os procedimentos de fechamento do empreendimento, ao final de sua vida útil, garantindo que a área esteja reabilitada para os usos preestabelecidos;

b) permitir a provisão de recursos durante a vida útil do empreendimento para fazer face aos custos do descomissionamento e reabilitação quando em curso;

c) reduzir os impactos socioeconômicos do fechamento do empreendimento;

d) estabelecer condições para a consolidação dos usos futuros previstos para a área e o estabelecimento do equilíbrio físico, químico e biológico, após o fechamento; e) estabelecer medidas para a redução dos riscos advindos de depósitos e fontes potenciais de contaminação e para estabilização dos passivos ambientais na área.

A definição ou estratégias dos usos potenciais da área para seu desenvolvimento após o fechamento da mina, foram estabelecidas no Plano de Fechamento de acordo com a MSS (2000).

Os Programas de Fechamento são: Programa de apoio à diversificação econômica dos municípios, Programas de desmobilização de empregados, Programa de comunicação social, Programa de fechamento das cavas da mina, depósito de estéril e barragem de rejeito, Programa de desmonte e demolição, Programa de descontaminação, Programa de reabilitação e revegetação, Programa de monitoramento revegetação. 
A última etapa de acordo com a MSS (2000) é o monitoramento Pós-Fechamento, onde faz parte também uma supervisão ambiental, a fim de identificar problemas extraordinários em tempo hábil para correções pró-ativas. 


\section{RESULTADOS E DISCUSSÃO}

Os dados analisados foram baseados nos problemas levantados no Estudo de Caso de grande empreendimento na Amazônia: o Projeto Sossego no Estado do Pará, dandose ênfase nos aspectos socioeconômicos. As diversas falhas estruturais encontradas, nos EIA/RIMA que dificultam a implementação dos empreendimentos, serviram como elementos para a elaboração dos questionários, que foram encaminhados para diversos especialistas na área ambiental os quais trabalham com Avaliação de Impacto Ambiental, tendo como procedimento o Estudo de Impacto Ambiental (EIA/RIMA).

Neste estudo será apresentada uma análise crítica e descritiva dos resultados dos questionários, além da avaliação dos impactos socioeconômicos do Projeto Sossego.

Foram selecionadas algumas questões para serem demonstradas através de gráficos, por apresentarem os aspectos mais relevantes na discussão de estudo de impacto ambiental, e as demais serão apresentadas através das análises mencionadas anteriormente.

\subsection{Público alvo}

Definido o público alvo (especialistas que desenvolvem atividades com Avaliação de Impacto Ambiental), constatou-se então, a dificuldade em adquirir estes dados, pois eles não se encontram disponiveis em nenhum órgão.

Foram enviados 112 questionários, obtendo-se o retorno de 28 ( $25 \%$ da amostra), a diversos profissionais em vários Estados do Brasil (Figura 3, 4, 5, 6) sendo que as 22 perguntas do questionário são fechadas e apenas 1 aberta; para esta questão utilizou-se como critério para categorização, o agrupamento das respostas mais freqüentes. 


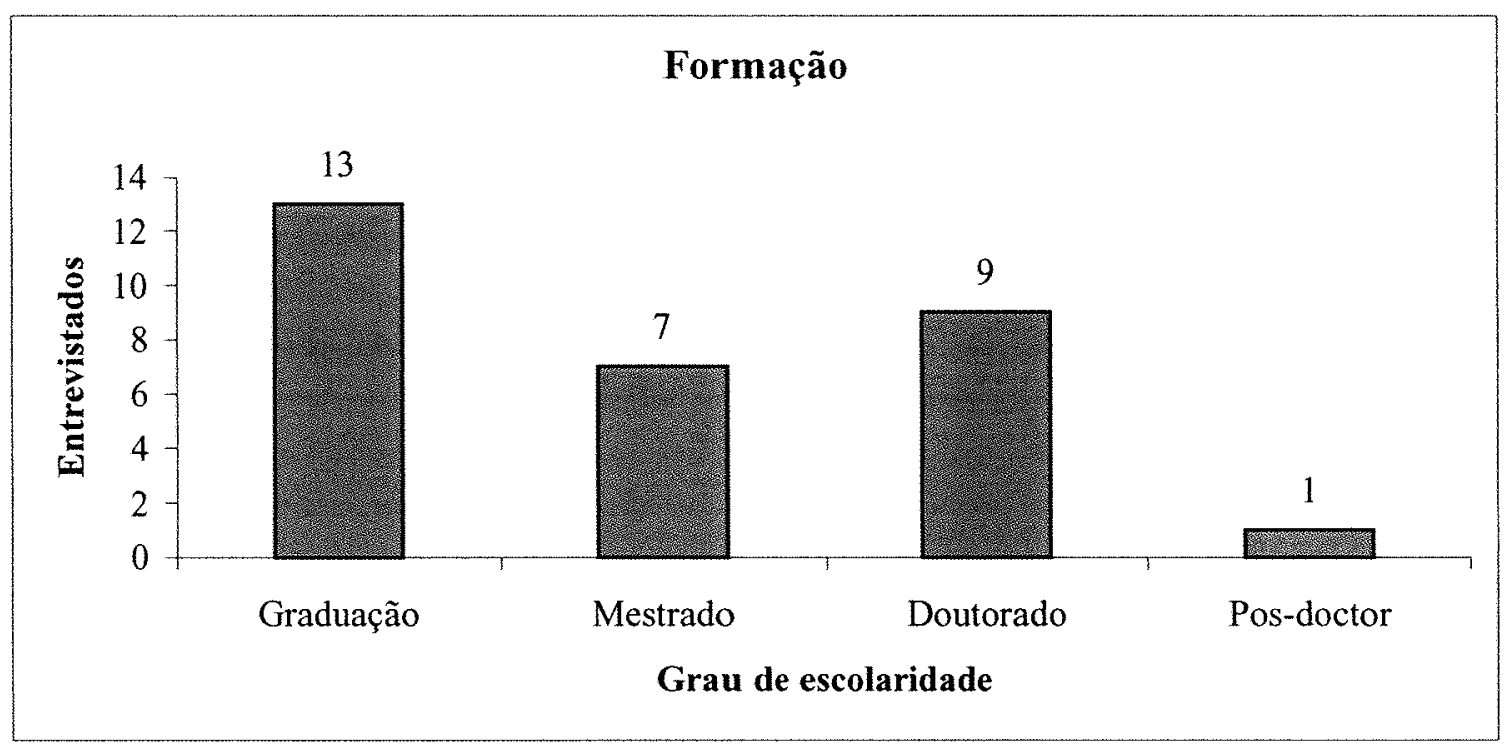

Figura 3 - Nivel de escolaridade

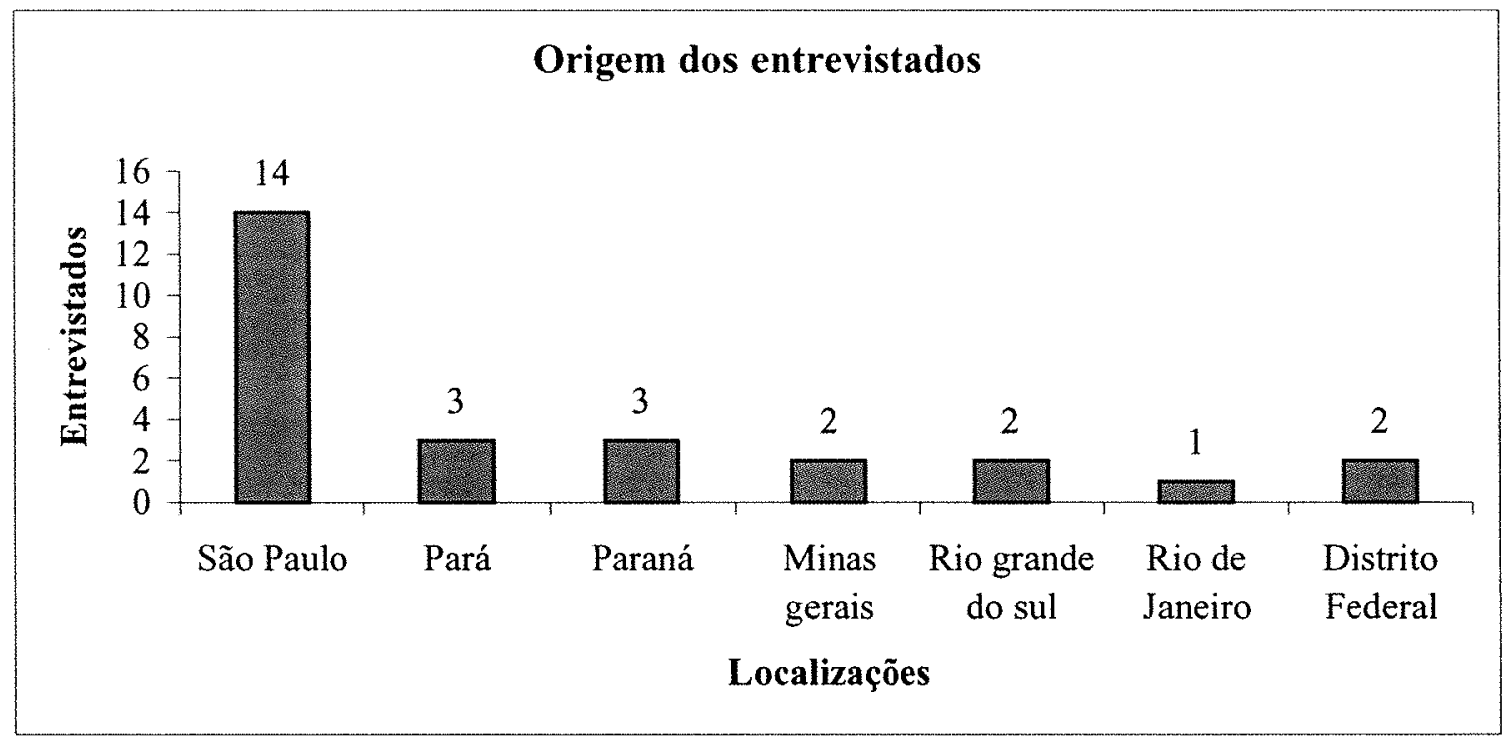

Figura 4 - Naturalidade dos especialistas 


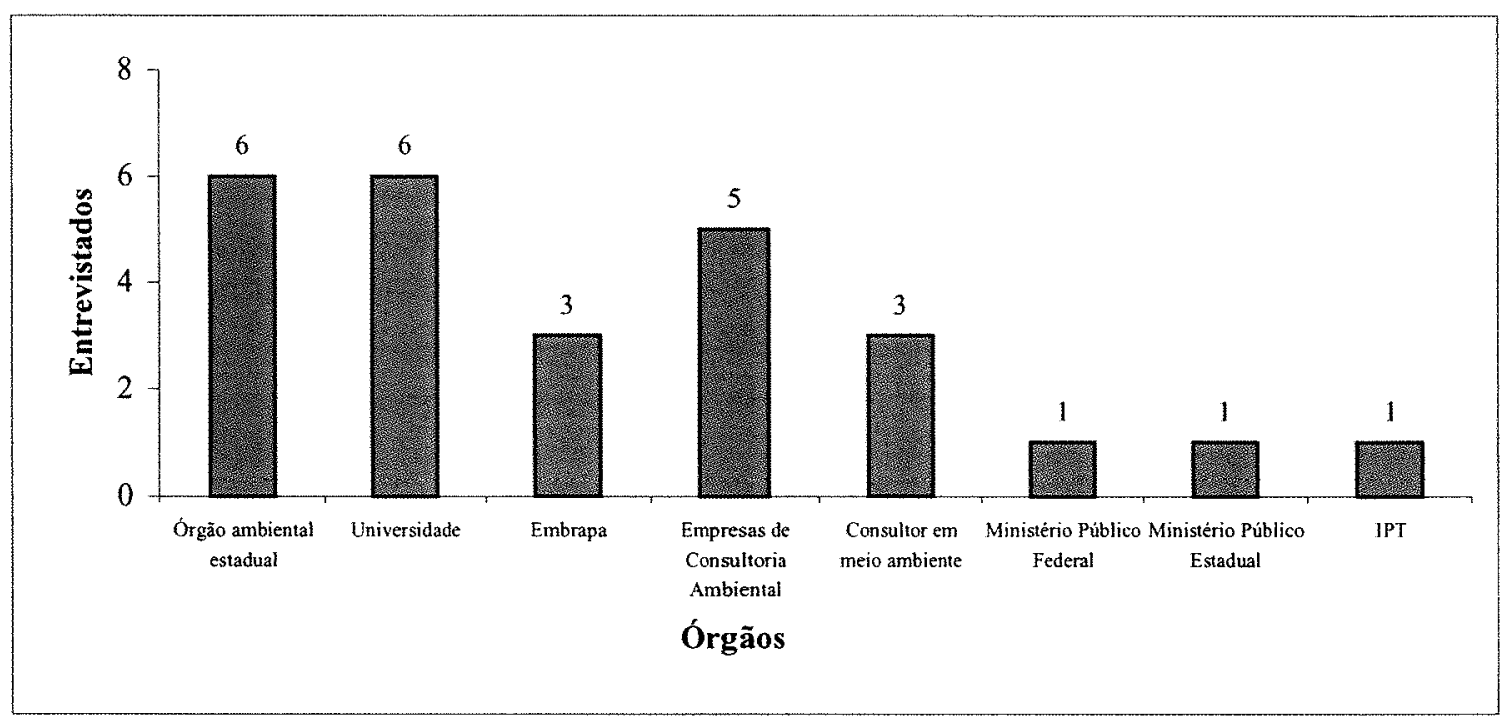

Figura 5 - Instituições dos especialistas

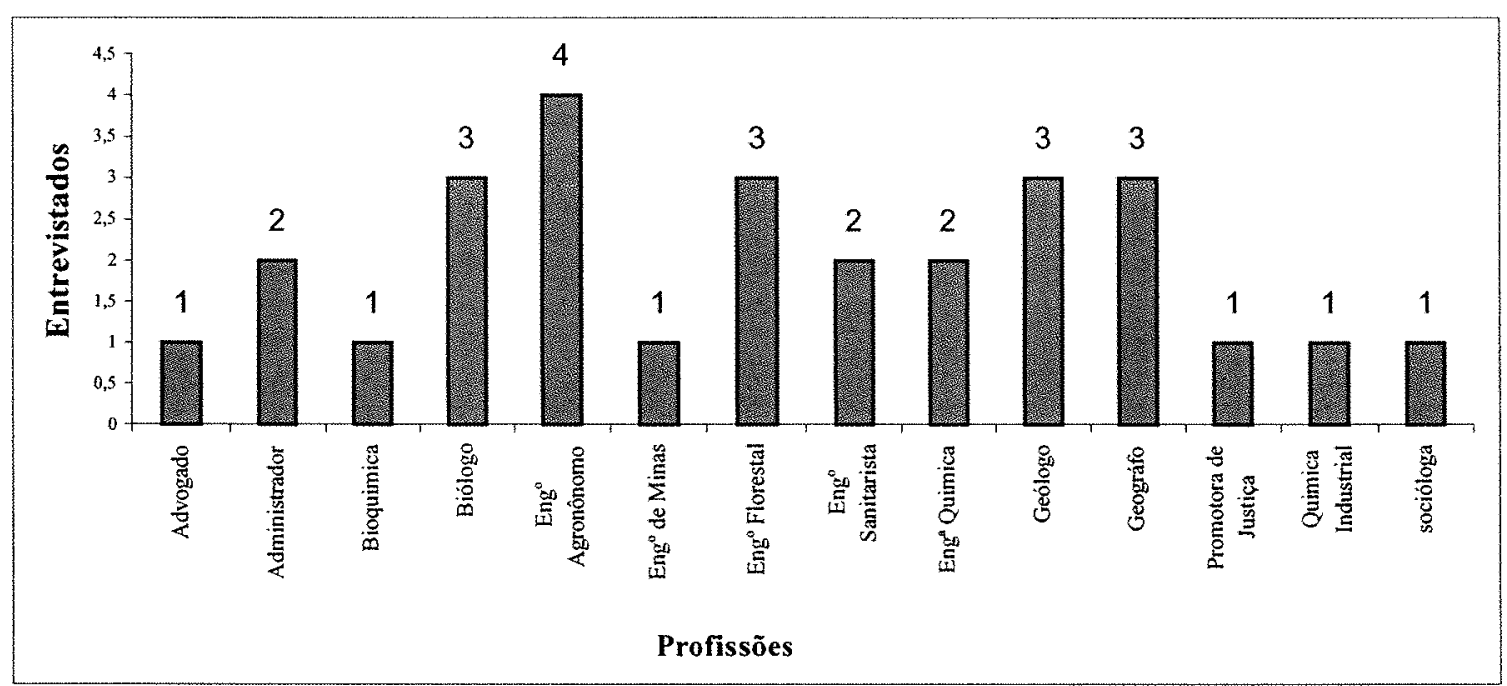

Figura 6 - Profissões dos Pesquisados

O problema encontrado neste procedimento, foi à demora no retorno da resposta, mesmo sendo via on-line.

A análise das questões seguirá a ordem das questões do questionário: 


\subsubsection{Qualidade dos Termos de Referência:}

Segundo Dias (2001) que fez um estudo semelhante, relata que uma vez definido que uma ação ou projeto deve ser submetido ao processo completo de avaliação de impacto ambiental, o passo seguinte é o estabelecimento do termo de referência que irá nortear os estudos ambientais. Denomina-se termo de referência ao documento no qual se registram as conclusões e decisões emanadas da atividade de identificação das principais questões que devem ser tratadas no estudo de impacto ambiental, assim como dos estudos necessários para o adequado tratamento destas questões.

No que diz respeito quanto aos especialistas consultados, $50,00 \%$ afirmam que os Termos de Referência são muitos genéricos, e apenas $21,43 \%$ acreditam que são documentos precisos; $53,57 \%$ definem os Termos de Referência como poucos objetivos, enquanto que $21,43 \%$ dizem o contrário; $64,29 \%$ acham que o Termo de Referência deveria ser anexado ao EIA e apenas 10,71\% não concordam com a anexação; 53,57\% afirmam que os Termos de Referência necessitam de instrumentos normativos e apenas 17,86\% acreditam o contrário. No EIA da MSS o Termo de Referência não foi possivel de ser encontrado nem no órgão ambiental, sendo impossível a sua consulta.

Isso demonstra que apesar de ser um instrumento orientador para a elaboração de qualquer tipo de Estudo de Impacto ambiental, não tem atendido satisfatoriamente ao seu objetivo que é estabelecer as diretrizes orientadoras, contéudo e abrangência do estudo exigido do empreendedor, em etapa antecedentes à implantação da atividade modificadora do meio ambiente.

Isto reflete bem na Resolução 001/86 que é muito generalista, enquanto a Resolução 237/97, já define quais os empreendimentos que serão necessários estudos de impacto ambiental, alterando profundamente o regime inaugurado pela Resolução 001/86 e tratou do licenciamento ambiental de forma mais ampla, abrangendo todas as atividades consideradas potencialmente poluidoras ou degradadoras do meio ambiente, não apenas as que tenham significativo impacto ambiental. Seu Anexo relaciona todas as atividades sujeitas ao licenciamento ambiental, inclusive as que não causem significativo impacto ambiental. Inclui, também, as relacionadas no artigo $2^{\circ}$ da Resolução 001/86 
mas o faz genericamente, sem as condicionantes específicas caracterizadoras da presunção de significativo impacto (Acker, 1998).

Normalmente os termos de referência apresentam-se extremamente genéricos, não atendem aos objetivos do projeto, deixando com isso de se estudar aspectos importantes dos diversos meios, ficando a EIA/RIMA, com deficiências na sua estrutura.

É importante propor como alternativas, o desenvolvimento de termo de referência mais específico, que venham atender aos estudos ambientais propostos, onde se possa avaliar as condições da biodiversidade para a implantação de projetos ambientais. Uma segunda alternativa seria repensar a reformulação da Resolução 001/86, com objetivo de atender aos requisitos dos estudos.

Santos (1999) encontrou resultados semelhantes em seu estudo de caso analisado onde a falta de informações adequadas e suficientes sobre o local do empreendimento e seu potencial modificador, aliado à falta de participação de outros órgãos da administração pública, que atuam na área ambiental, tem levado à desconsideração de interesses setoriais e a desconexão com outros projetos e atividades existentes na área de influência do empreendimento proposto. Em geral, os termos de referência apresentados pelas Secretarias de Meio Ambiente normalmente têm seguido um modelo único baseado na legislação federal, de características genéricas, deixando de contemplar as especificidades do local proposto para a atividade.

As deficiências infraestruturais e/ou a insuficiência de recursos materiais e financeiros muitas vezes impedem que os técnicos do órgão ambiental possam visitar o local do empreendimento proposto para coletar informações complementares e confirmar àquelas fornecidas pelo empreendedor. Freqüentemente, pelo reduzido número de pessoal especializado, as organizações estaduais de meio ambiente (OEMA) solicitam que o próprio empreendedor elabore o termo de referência, reservando-se o papel de sugerir alterações, analisá-lo e finalmente, aprová-lo ou não. Em alguns casos, com a finalidade de agilizar o processo e licenciamento ambiental, o empreendedor adianta-se à solicitação e apresenta a proposta do Termo de Referência.

O Termo de Referência bem elaborado é um dos passos fundamentais para que um estudo de impacto ambiental alcance a qualidade esperada. 
A dificuldade que o órgão de meio ambiente encontra para elaborar Termo de Referência de qualidade técnica decorre, em parte, da falta de conhecimento técnico sobre as caracteristicas do espaço sob a sua administração e sobre os efeitos ambientais advindos de atividades propostas. Este problema pode ser superado com o apoio de outros agentes sociais, tais como: comunidade científica, técnicos de outros órgãos públicos, organizações não-governamentais, pessoas fisicas e empresas com interesse na área.

Moreira (1993) chegou também a esta conclusão, que a regulamentação dos procedimentos administrativos é fundamental para que o processo de avaliação de impacto ambiental se realize ordenadamente, não porque as responsabilidades dos empreendedores e das autoridades ambientais precisem estar claramente definidas, mas também porque os interessados em participar, sejam eles outras instituições governamentais ou grupos sociais afetados, precisam conhecer os mecanismos de participação. Caso contrário, os interessados não encontram os meios de se envolver ou somente o fazem quando não há mais tempo para discutir questões, para eles importantes, que poderiam ter sido mais bem incorporadas ao estudo, nas fases iniciais do processo.

\subsubsection{Recursos financeiros destinados à elaboração dos EIA/RIMA}

Moreira (1993) afirma que um fator que prejudica a elaboração do estudo de impacto ambiental é a exigüidade do prazo de execução ou das verbas destinadas a custeá-lo. Nas empresas públicas, as firmas de consultoria concorrem a licitações nas quais o critério é o menor preço dos serviços, o que significa entregar o estudo, na maioria das vezes, não ao concorrente mais qualificado, mas àquele que subestimou seu detalhamento ou sua profundidade.

Há casos em que o maior custo apresentado chega a ser mais de dez vezes o menor. Fatalmente, a qualidade do estudo do relatório de impacto ambiental reflete a falta de critério técnico adotada no julgamento da concorrência. A premência do início das obras, pelos mais diferentes motivos, faz com que o empreendedor ofereça contratos de consultoria com tempo de execução insuficiente para a coleta de dados, à elaboração 
de métodos apropriados, ou mesmo para a consecução de resultados bem fundamentados. Como conseqüência, o estudo de impacto ambiental deixa de apresentar informações seguras ou atender adequadamente aos termos de referência.

Isso leva às deficiências na amplitude dos diagnósticos realizados, como por exemplo o estudo da biodiversidade.

Os custos de elaboração do EIA/RIMA da MSS referente ao estudo de caso, não foram informados pela empresa, e deveriam constar num documento em que sociedade pudesse ter acesso com a finalidade de se fazer uma correlação entre o valor do empreendimento e valor do estudo.

Isto vem corroborar com o resultado da pesquisa onde $57,14 \%$ dos consultados afirmam que o principal critério das licitações é o menor preço dos serviços, enquanto que $7,14 \%$ confirmam que o maior peso é a qualificação da equipe técnica, e $32,14 \%$ não têm informações a esse respeito (Figura 7).

Ainda de acordo com os consultados, 32,29\% afirmam que as escolhas das empresas de consultoria nas licitações têm sido pelo menor custo, mesmo sendo pouco qualificadas, enquanto que $10,71 \%$ confirmam que são preferidas as empresas mais qualificadas, mesmo com custo maiores; $28,57 \%$ não têm informações a esse respeito (Figura 8).

Os especialistas afirmaram que em $53,57 \%$ dos estudos ocorrem problemas em decorrência dos recursos reduzidos, fazendo com que os EIA percam na qualidade e acabem muitos simplicados e poucos seguros, enquanto que $14,29 \%$ acreditam que os estudos são detalhados e de grandes profundidades; $14,29 \%$ responderam que não têm informações a esse respeito (Figura 9).

Ainda de acordo com os mesmos profissionais $60,71 \%$ afirmam que a falta de recursos tem provocado cronogramas apertados, com pouco tempo para os estudos de campo, enquanto que $7,14 \%$ acreditam que os cronogramas têm sido amplos, oferecendo tempo suficiente para detalhados estudos de campo (Figura 10). 


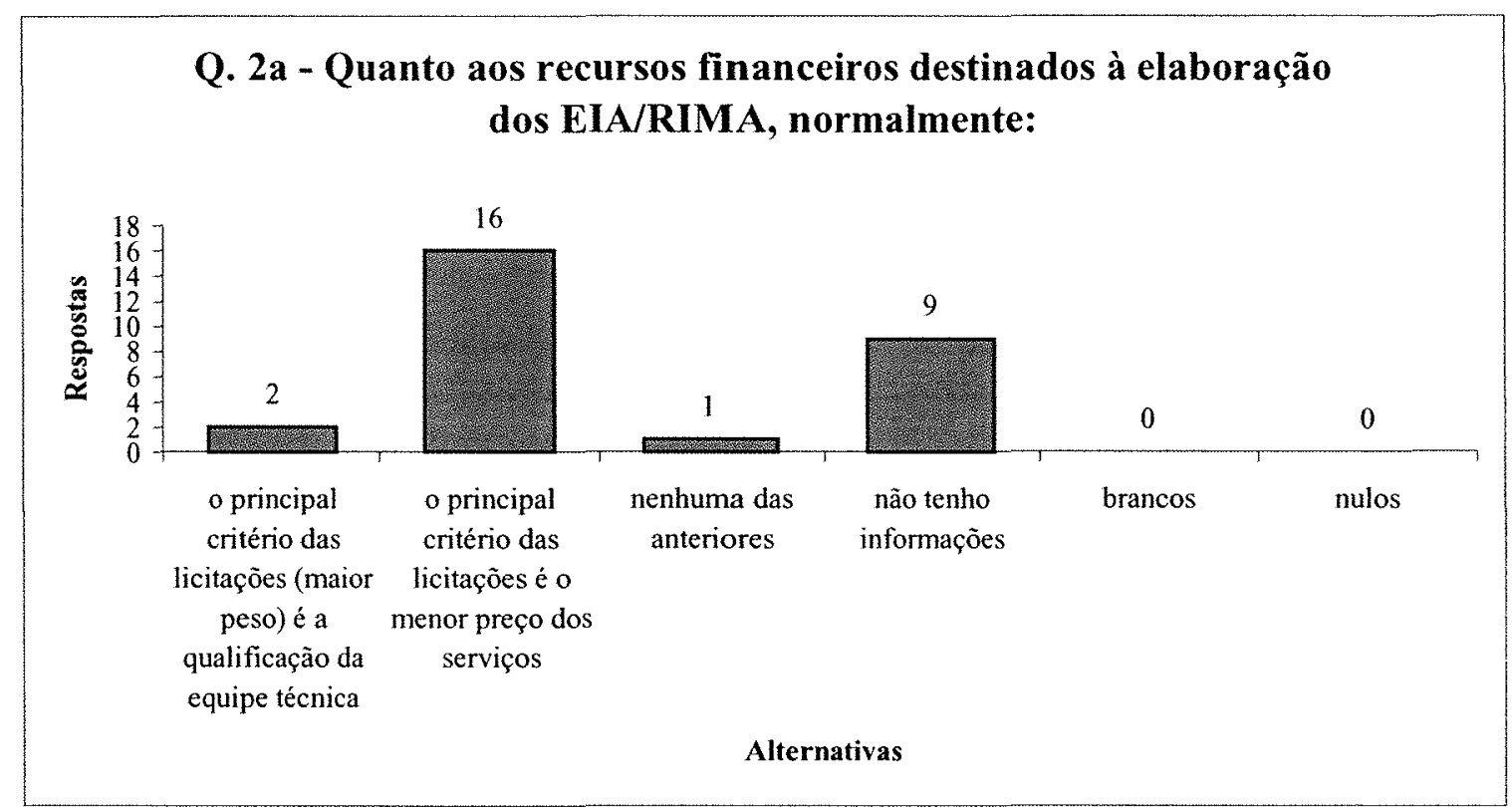

Figura 7 - Recursos financeiros destinados à elaboração dos EIA/RIMA

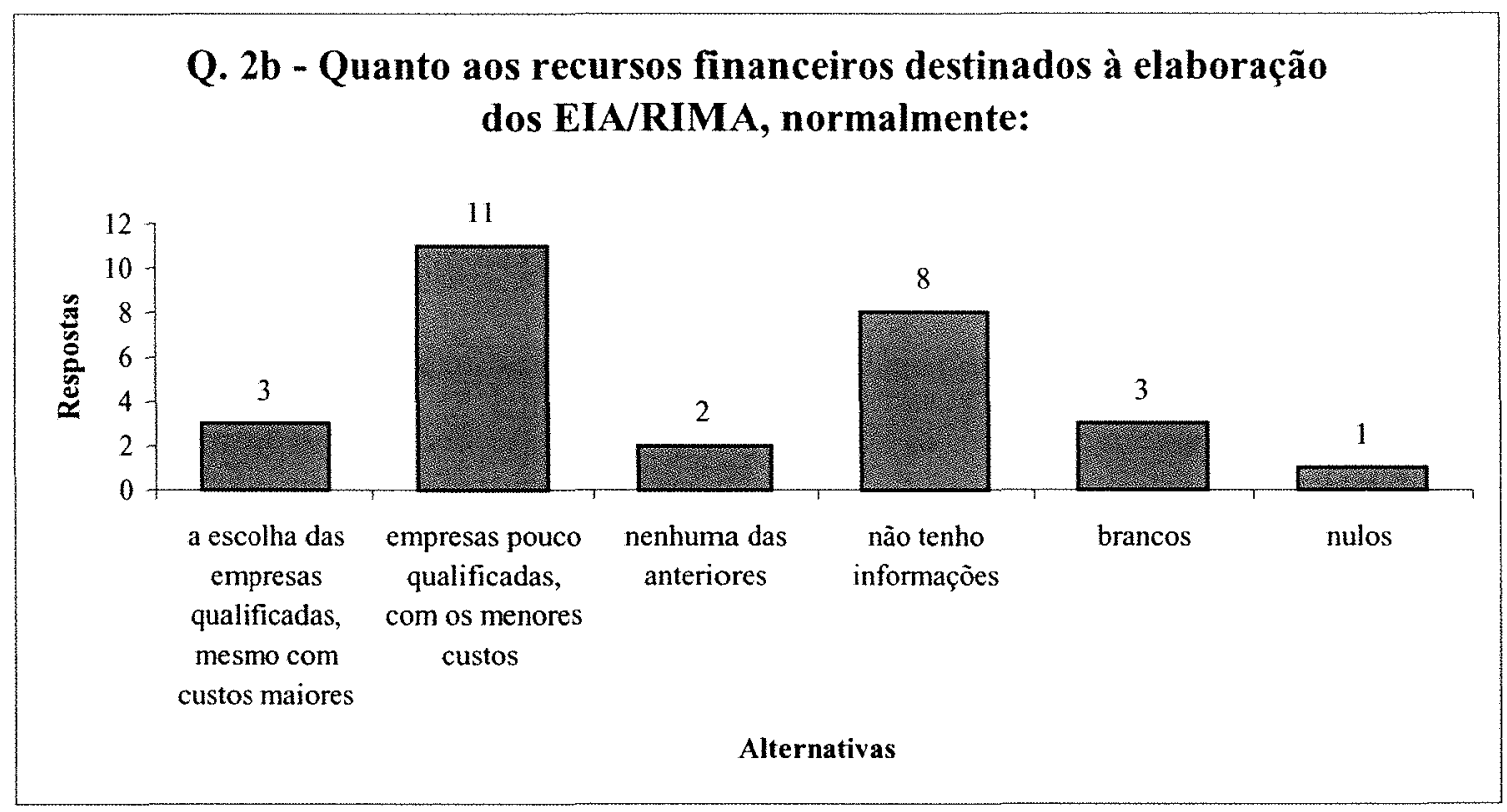

Figura 8 - Recursos financeiros destinados à elaboração dos EIA/RIMA 


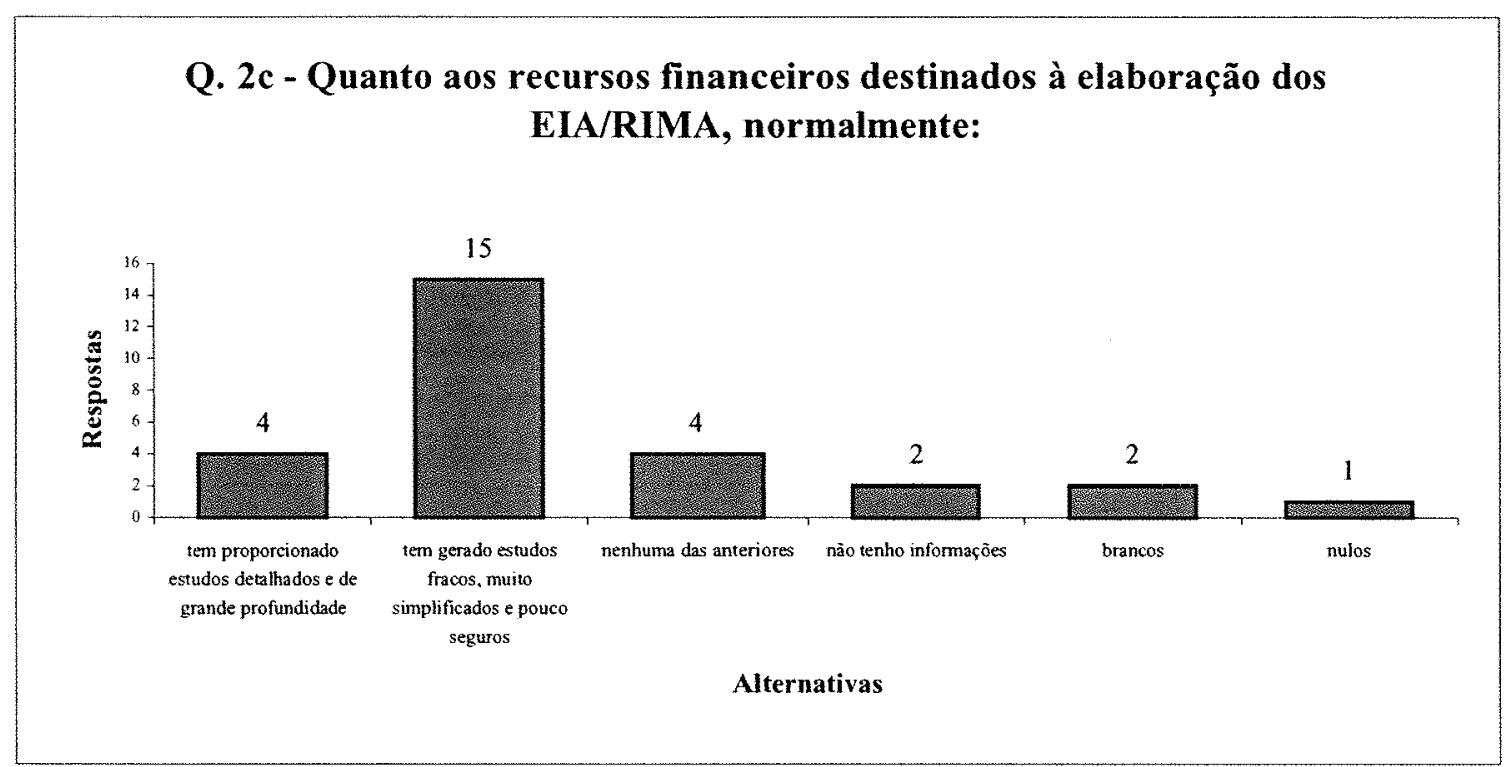

Figura 9 - Recursos financeiros destinados à elaboração dos EIA/RIMA

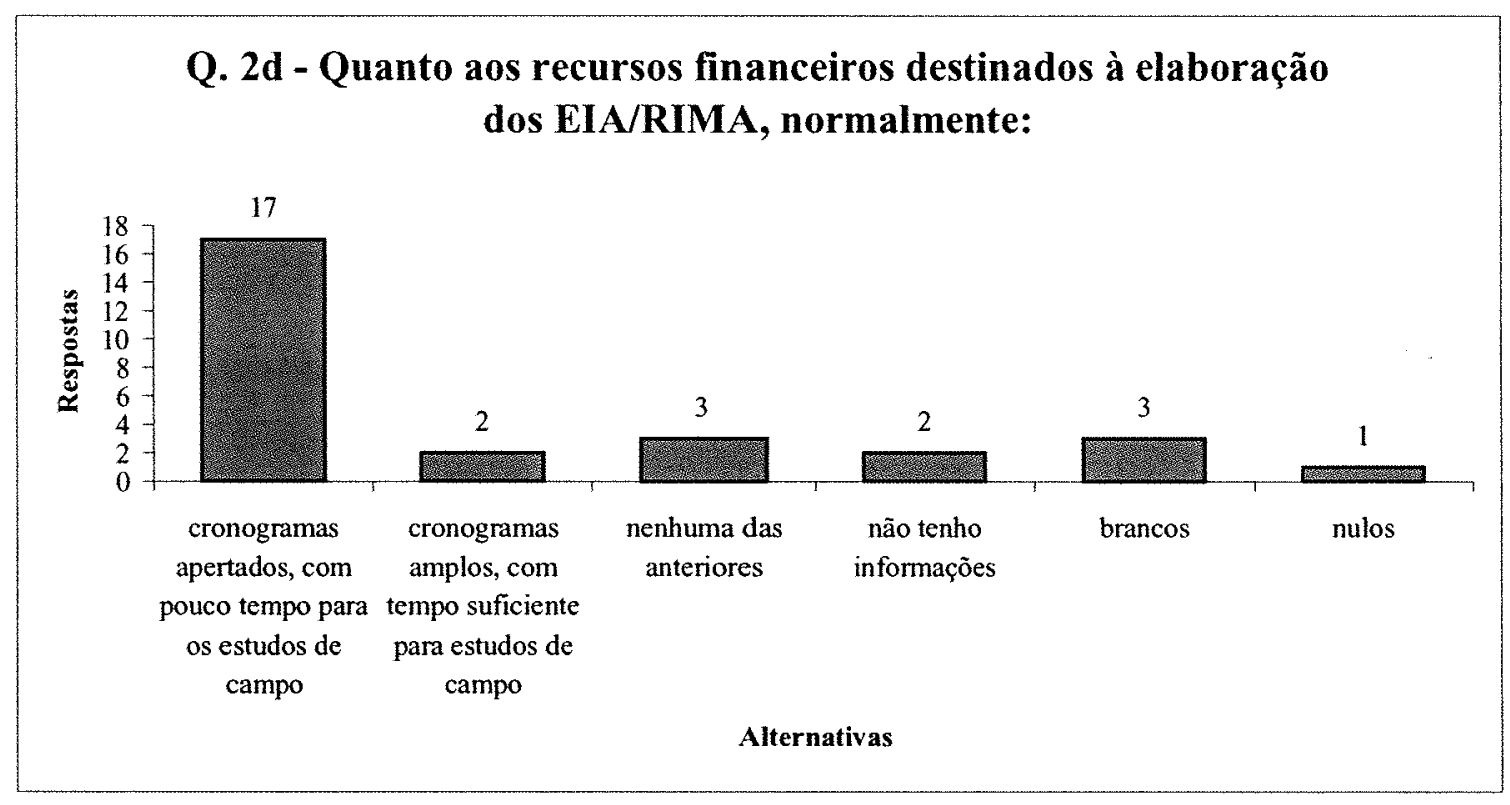

Figura 10 - Recursos financeiros destinados à elaboração dos EIA/RIMA 


\subsubsection{Prazos para execução do EIA}

O que ocorre com os EIA/RIMA é que os prazos de execução estão sendo muito reduzidos por parte dos empreendedores, em relação aos levantamentos que tem que ser feitos no campo. Isto tem uma implicação muito grande principalmente nos resultados dos estudos, porque podem ser áreas de difícil acesso, como ocorre na Amazônia, onde muitas vezes os deslocamento são longos e demoram alguns dias para se chegar ao local do trabalho.

Outro aspecto a ser analisado é em relação às obras de interesse nacional, como por exemplo a construção de hidrelétricas e linhas de transmissão etc., quando muitas vezes tem que ser elaborados os estudos em curtíssimo prazo, o que muitas vezes levam a se perder na qualidade e muitas vezes são estudos extremamente complexos que exigem um maior tempo.

Isto vem corroborar com os resultados encontrados que mostram que para os especialistas $53,57 \%$ afirmam que os prazos não são suficientes em decorrência da complexidade dos estudos nas diversas regiões do Brasil; enquanto que $17,86 \%$ dizem o contrário, enquanto que 14,29\% responderam nenhuma das anteriores e 14, 29\% não tenho informações quanto a esse tema (Figura 11).

Segundo $53,57 \%$ dos especialistas os prazos não atendem às dimensões dos empreendimentos e tem contribuído para fragilidade dos estudos, enquanto que $10,71 \%$ dizem o contrário, e 17,86\% informaram nenhumas das questões (Figura 12). 


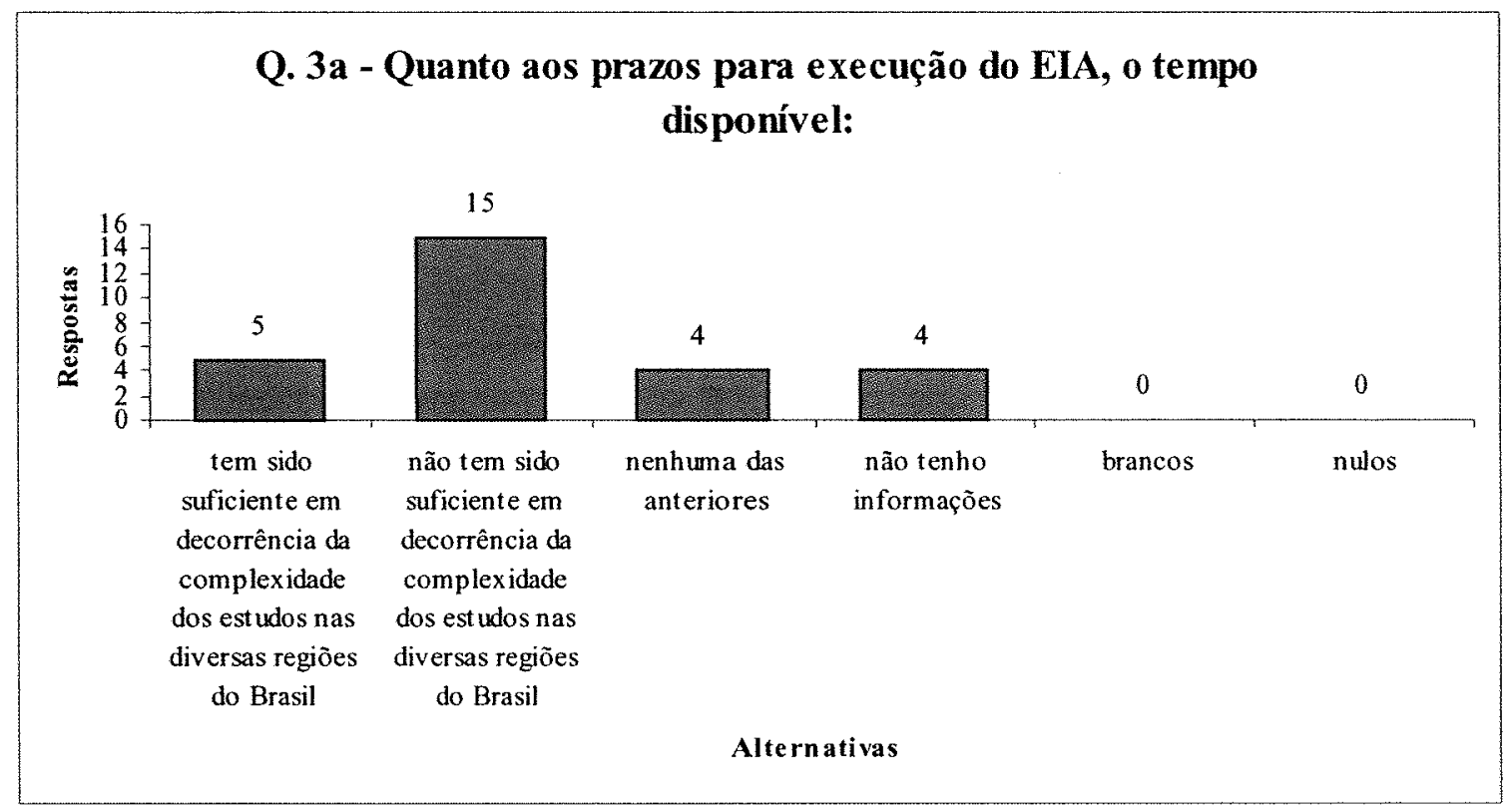

Figura 11 - Prazos para execução e elaboração do EIA/RIMA

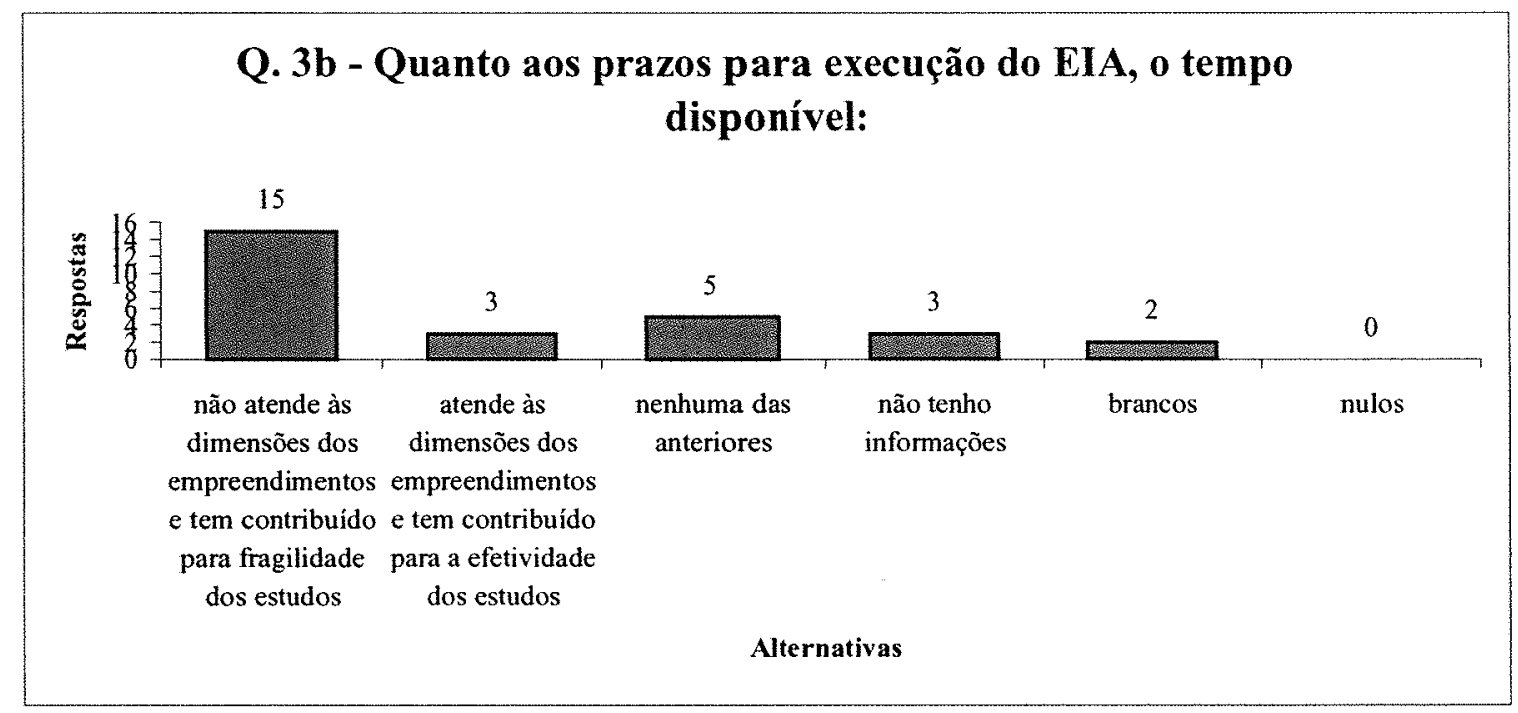

Figura 12 - Prazos para execução e elaboração do EIA/RIMA

\subsubsection{Os EIA quanto a sazonalidade dos estudos em ambientes complexos}

De acordo com os especialistas $32,14 \%$ afirmam que os estudos são realizados em apenas em uma época do ano, 28,57\% confirmam que os estudos estão cumprindo com a sazonalidade; enquanto que $28,57 \%$ não tem informações a respeito (Figura 13 ). 
Os projetos de grande porte, principalmente nos ambiente onde ocorrem grandes variações sazonais necessitam de levantamento no inverno e verão, caso contrário deixam de observar as variações em função da sazonalidade. O que vem ocorrendo nos estudos de impacto ambiental na Amazônia, é que a maioria dos estudos deixa de cumprir com este item não apresentando levantamentos nos dois períodos. Tal fato é mais grave no meio Biólogico.

No caso da MSS, o estudo não contemplava este levantamento na apresentação do EIA/RIMA ao órgão ambiental, para efeito de licenciamento e nem no período da Audiência Pública. Até a época da coleta de dados (março/2003), o estudo ainda não tinha sido apresentado ao órgão ambiental. No entanto neste período a SECTAM já havia emitido a licença de instalação para o empreendimento.

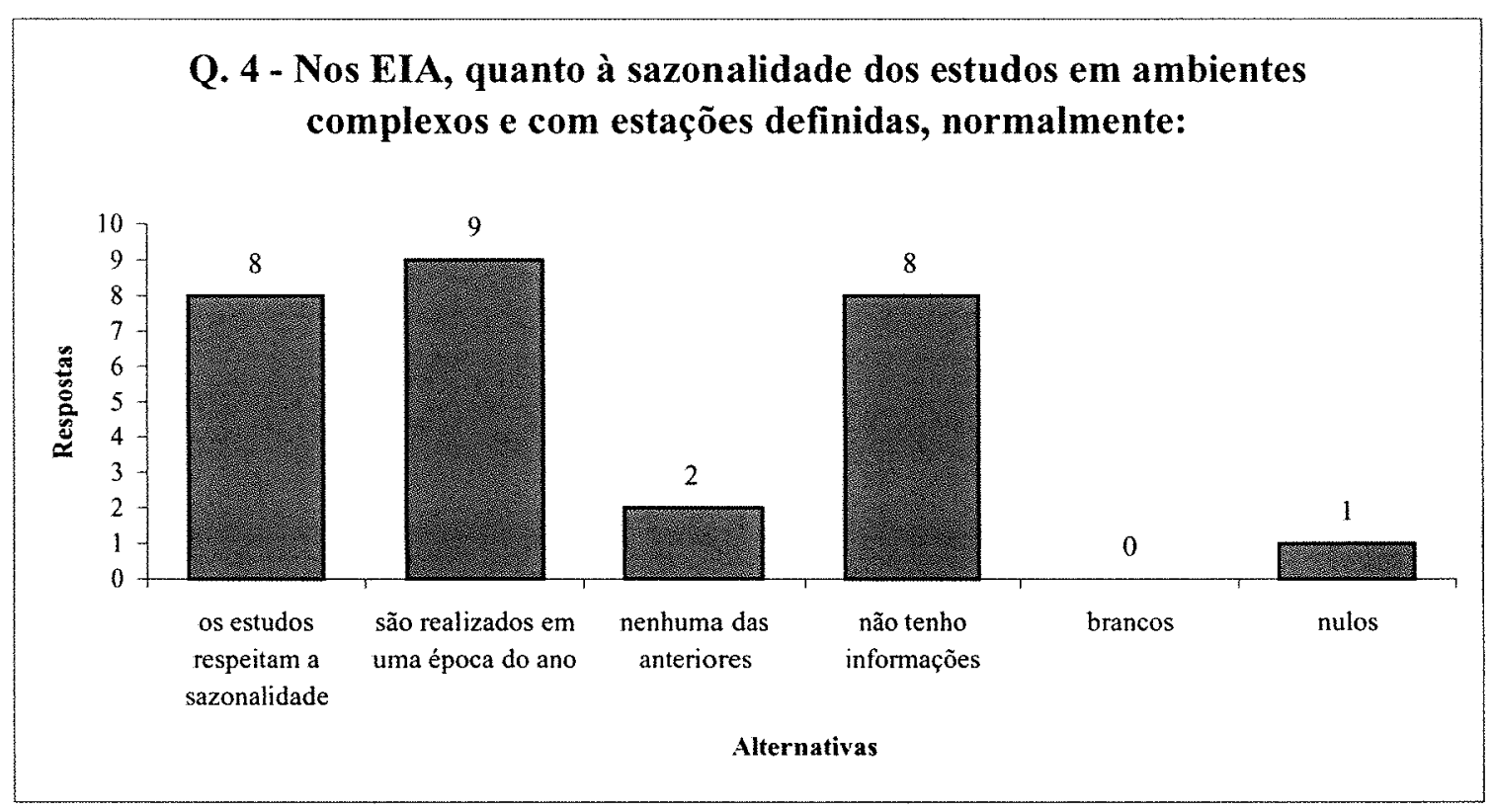

Figura 13 - Realização de estudos ambientais de acordo com a sazonalidade

\subsubsection{Realização de estudos ambientais para Unidades de Conservação ou Reserva Indígenas}

Entre os especialistas consultados, $42,86 \%$ afirmam que não são realizados estudos particularizados para estas áreas protegidas, enquanto que $32,14 \%$ dizem ao contrário, e 17,76\% não tem informações sobre esse tema, (Figura 14). 
Outro fator importante é a freqüente ausência de estudos em áreas especialmente protegidas, onde se deveriam fazer diagnósticos particularizados para Unidades de Conservação e Reservas Indígenas. Os Estudos de Impacto Ambiental, que se localizam no entorno de áreas indígenas, ficam sujeitas às autorizações da União as quais são previstas no Decreto n. ${ }^{\circ} 24$, de 4 dezembro de 1991, que dispõe sobre as ações visando a proteção do meio ambiente em terras indígenas.

De acordo com o Sistema Nacional de Unidades de Conservação (SNUC), quando um empreendimento afetar Unidade de Conservação específica ou sua zona de amortecimento, o licenciamento só, poderá ser concedido mediante autorização do órgão responsável por sua administração.

No caso do projeto da MSS não foi solicitado estudo complementar pelo órgão ambiental, em virtude da área estar contígua à FLONACA.

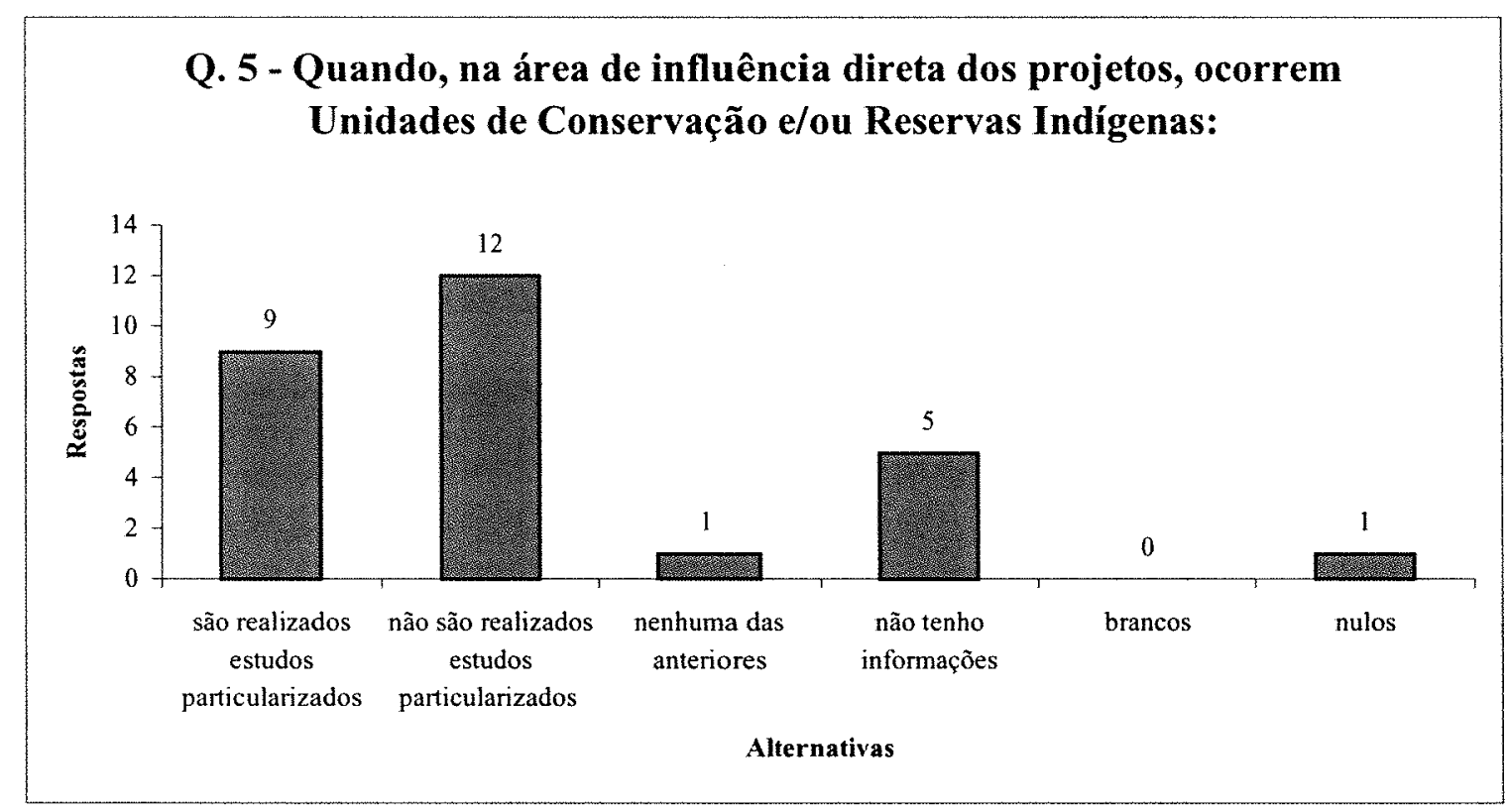

Figura 14 - Área de influência direta das Unidades de Conservação e/ou Reservas Indigenas 


\subsubsection{Os EIA a participação da sociedade civil em audiências públicas}

Um dos procedimentos mais importantes na Avaliação de EIA/RIMA é a discussão com a partipação da sociedade civil em Audiências Públicas, onde houvesse uma ampla divulgação, para que o público pudesse discutir os problemas oriundos com a implantação dos projetos. Isso pode ser conseguido, por exemplo, pela exposição pública do plano e de seus objetivos, através de debates entre técnicos de órgãos de controle ambiental, responsável pelo projeto; e representantes da comunidade, em audiência pública, sob a moderação dos órgãos ambientais. Em certas circunstâncias, pode-se prever até plebiscitos a fim de se avaliar a posição de uma comunidade quanto a um dado projeto (Tomasi, 1993).

Isto vem confirmar o resultado da pesquisa (Figura 15) pois $57,14 \%$ afirmam que RIMA não tem propiciado a participação efetiva na sociedade, mas por lado $21,43 \%$ dizem o contrário.

Ainda de acordo com consultados, 64,29\% afirmam que a ausência de reuniões preparatórias para audiências tem prejudicado a participação da sociedade, e 10,71\% dizem o contrário (Figura 16).

De acordo com os especialistas $53,57 \%$ afirmam que a linguagem técnica no RIMA, tem prejudicado a efetiva participação da sociedade civil nos projetos, enquanto que $10,71 \%$ dizem o contrário, e 21,43\% não tem informações quanto ao assunto (Figura $17)$. 


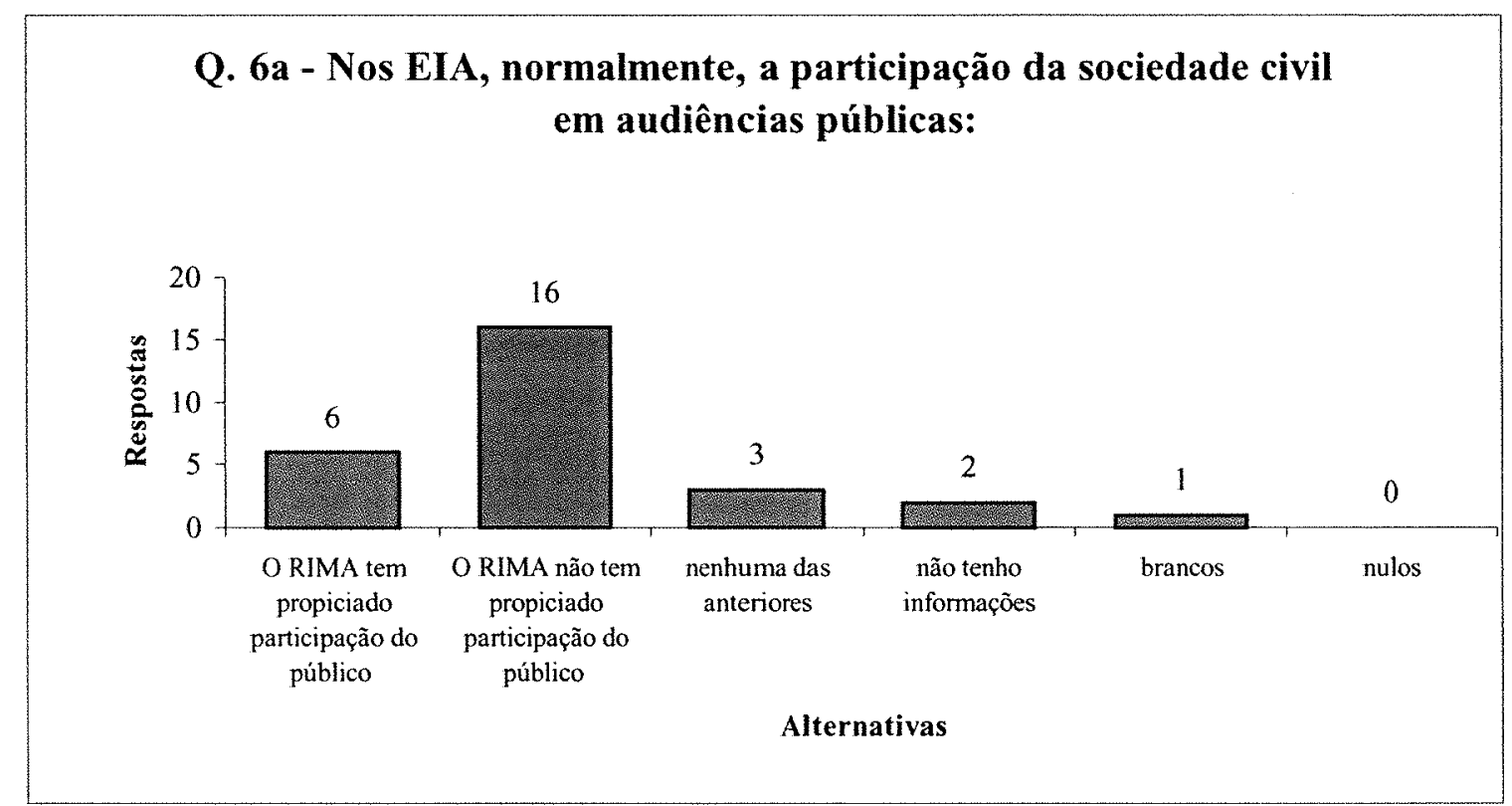

Figura 15 - Participação pública nas decisões

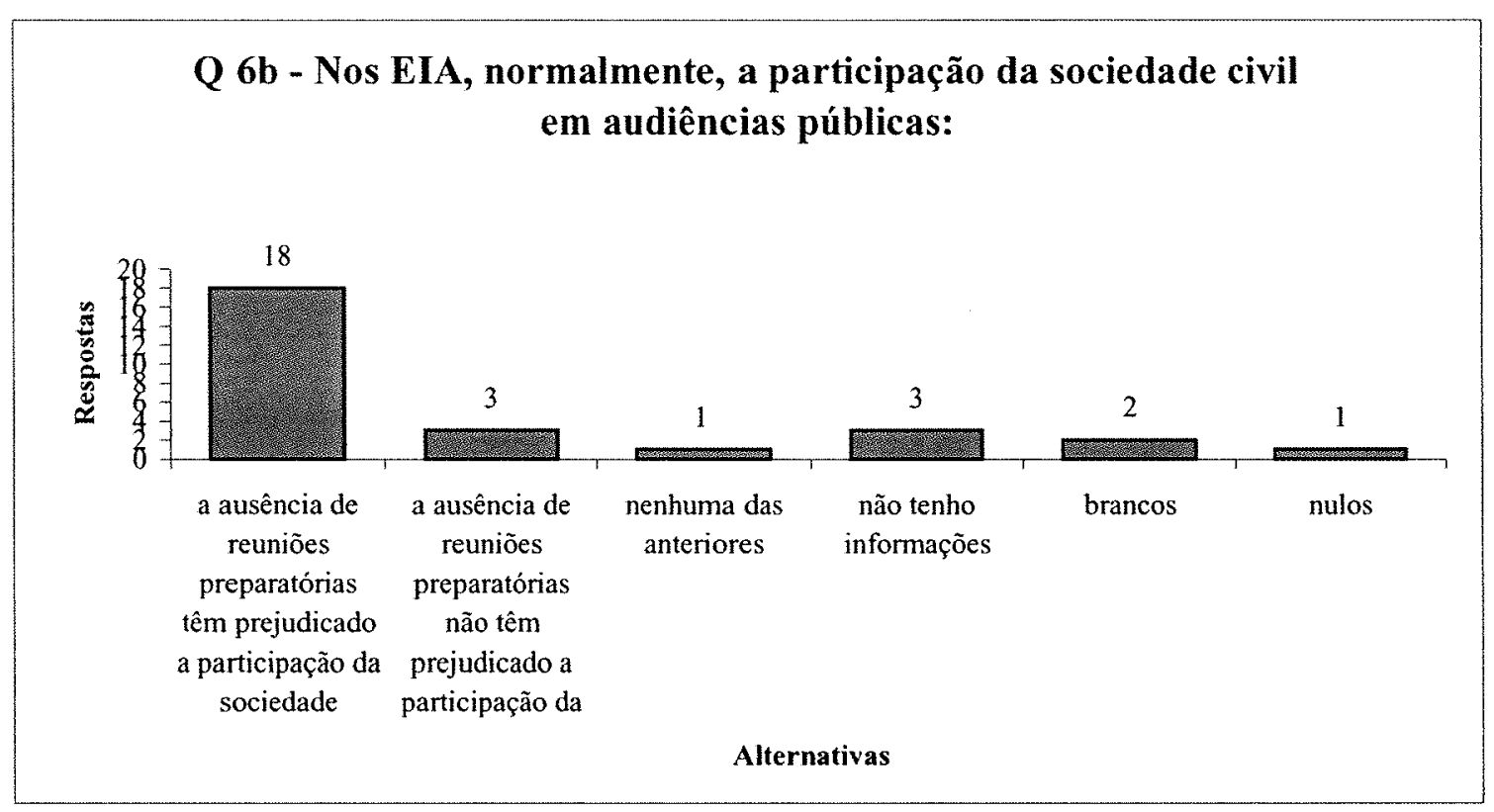

Figura 16 - Reuniões preparatórias para audiências públicas 


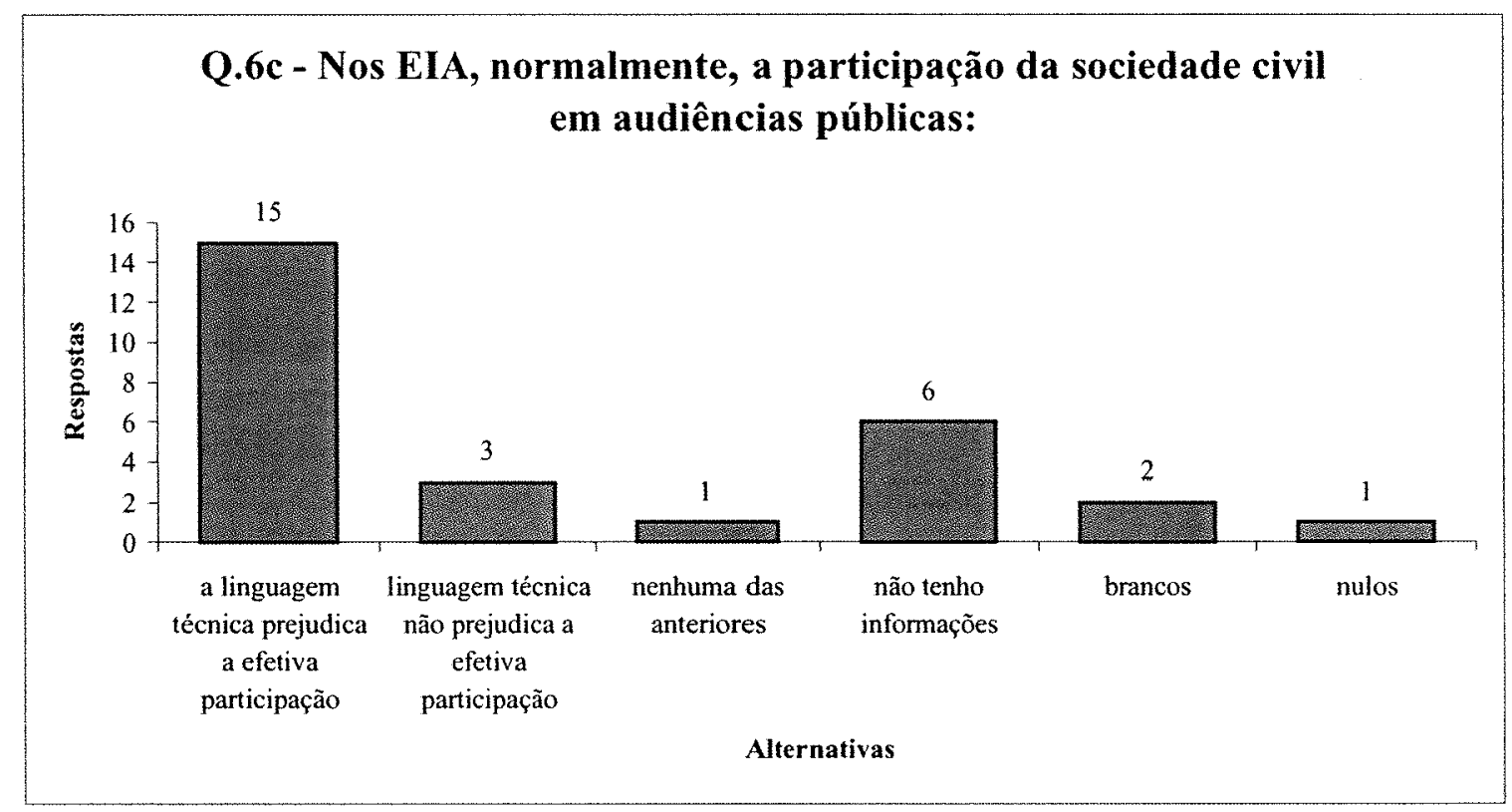

Figura 17 - A linguagem técnica nos EIA/RIMA

As audiências públicas são consideradas parte fundamental do processo de AIA. É um dos espaços que a comunidade afetada possui para conhecer profundamente o empreendimento posto em questão, colocar seu ponto de vista e debater com equipe multidisciplinar que elaborou o EIA e o RIMA. Entende-se que, resguardando o sigilo às matérias protegidas pelo segredo industrial e mercantil, o restante é de livre acesso à comunidade (Resolução Conama 001/86).

Hoje o que está sendo feito em termos de Audiências Públicas, são apenas exposição a respeito dos projetos, onde a participação da sociedade é quase que decorativa e inexistente, em decorrência da elaboração do RIMA em linguagem técnica; este deveria ser um documento que facilitasse a compreensão sobre o empreendimento.

Tendo em vista que a elaboração de um RIMA constitui-se em um instrumento, previsto pela legislação ambiental, de comunicação entre setores especializados, empreendedores e a comunidade sujeitam aos impactos da exploração econômica, é necessário que tal documento atinja o público-alvo mediante uma linguagem popular.

Constatou-se no estudo da MSS, a predominância no texto do RIMA de termos técnico-científicos, como se fora direcionado unicamente à apreciação acadêmica e de profissionais especializados na matéria. Alguns trechos ostentam linguagem dificil, 
incompreensivel aos leigos, o que evidencia dificuldades de compreensão ou entendimento de grande parte da população envolvida. Esta realidade afeta, sobremaneira a absorção das campanhas de esclarecimento e de educação ambiental, por exemplo, dirigidas aos comunitários de nenhuma, baixa e até média escolaridades e niveis culturais.

De acordo com entrevistados (Figura 18), 60,71\% afirmam que o RIMA não tem sido um instrumento capaz de informar à sociedade sobre os impactos que ocorrerão com a implantação do empreendimento, enquanto que $21,43 \%$ dizem o contrário.

De acordo com $67,86 \%$ dos especialistas a maioria das empresas de consultoria ambiental não tem sido capaz de elaborar o RIMA em linguagem para leigos; enquanto que 3,57\% confirmam o contrário; e 17,86\% não tem informações quanto a esse assunto, conforme demonstrado na (Figura 19).

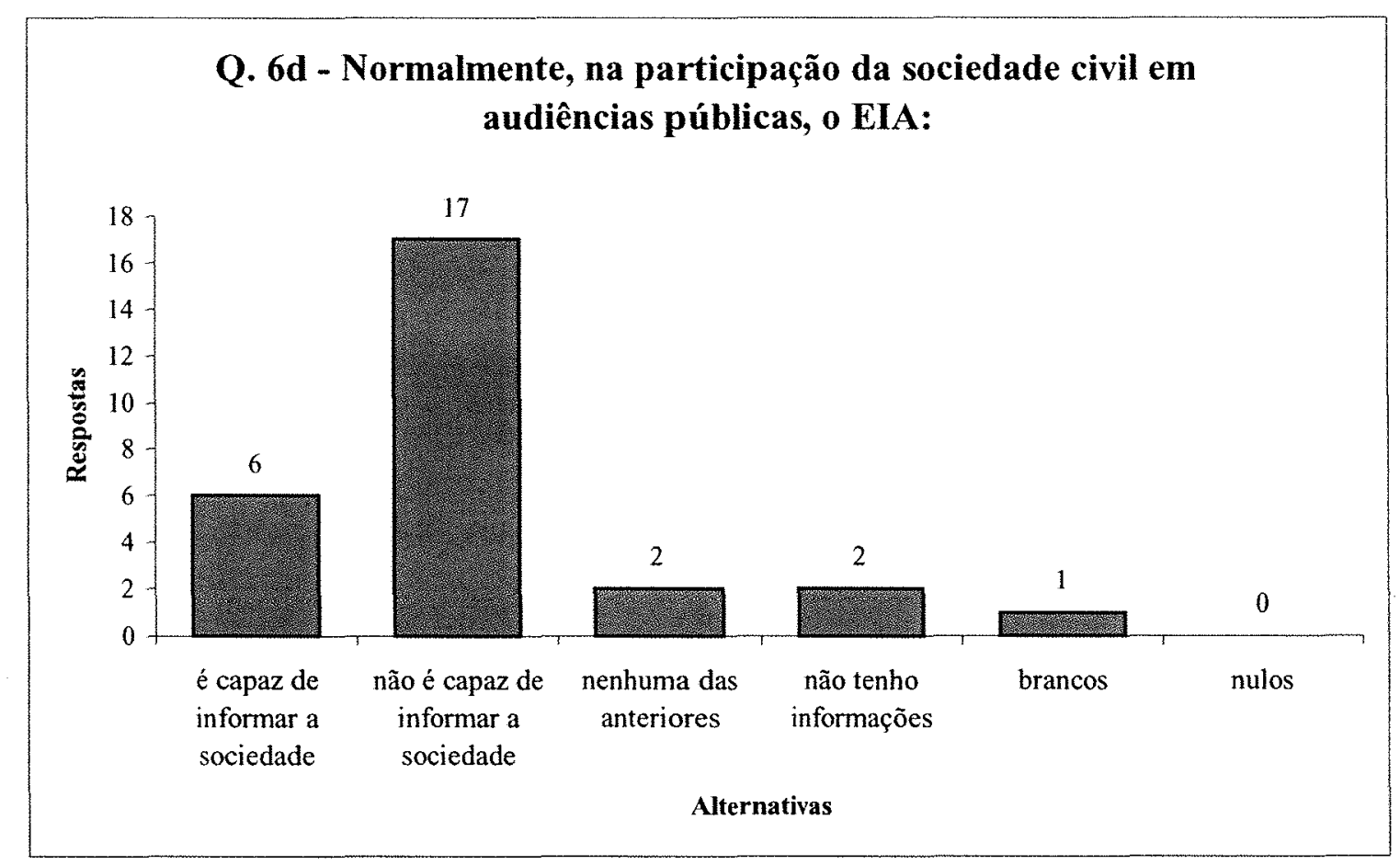

Figura 18 - Participação da sociedade civil em audiências públicas 


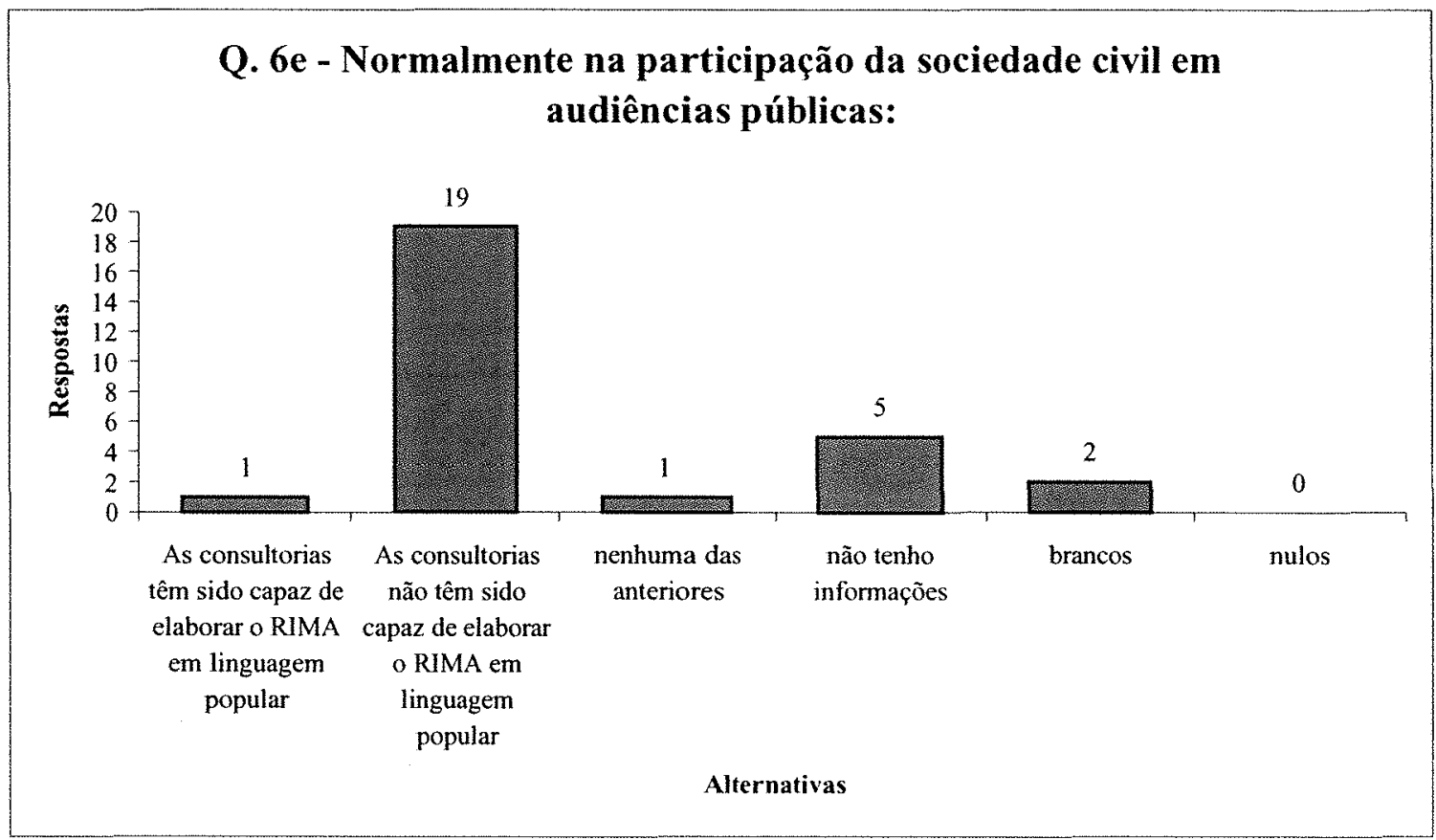

Figura 19 - Elaboração do RIMA em linguagem popular

Ademais, vislumbra-se um horizonte restrito na divulgação do RIMA, o qual deveria ser difundido com maior eficácia nas comunidades, de preferência nas organizações civis da sociedade, tais como associações de moradores, centros comunitários, grupos religiosos, recreativos, filantrópicos, culturais, entidades classistas, segmentos partidários e demais pessoas jurídicas de direito privado.

As audiências públicas deveriam ser mais dinâmicas e não tão defensivoexpositivo-contestatórias, sem debates, como ocorre hoje em dia.

No projeto da MSS, ocorreu apenas uma audiência pública em Canaã dos Carajás, e no processo do licenciamento não constava a ata da audiência pública e a fita com as filmagens da mesma, o que impossibilitou de levantar os dados sobre as sugestões da comunidade em relação ao projeto.

Este quadro se reflete na etapa de acompanhamento, pois as partes interessadas, em particular a população do entorno da área da mina, perdem a oportunidade de influir na decisão, pois ficam privadas das informações relativas aos termos e compromissos assumidos pelo proponente. Esta grave deficiência, na prática, impede que o público 
interessado exerça seu papel na fiscalização, cobrando dos órgãos ambientais e do proponente o cumprimento dos compromissos assumidos.

As deliberações do COEMA, que registram as decisões tomadas pelos conselheiros, não contribuíram no modelo estudado, para corrigir as imperfeições na transmissão de informações observadas ao longo do processo. Documentos concisos, em linguagem padronizada, limitam-se a aprovar o EIA/RIMA com base no parecer da SECTAM, afirmando a obrigatoriedade de cumprir as medidas propostas no EIA/RIMA. A deliberação do COEMA analisada menciona o EIA/RIMA, limitando-se a exigir o cumprimento das medidas contidas no parecer da SECTAM.

Para um empreendimento desse porte, no qual os maiores impactos são na área socioeconômica, deveriam ter sido realizadas várias reuniões preparatórias com a sociedade para que pudessem discutir a implantação do projeto.

Austin (2000) citado por Dias (2001) sustenta que a atividade de acompanhamento do processo de AIA, ao envolver as comunidades locais, representa, mais do que um exercício científico ou administrativo, uma oportunidade de melhoria do conhecimento e atenção da comunidade sobre o meio ambiente e sobre o projeto em si.

Não resta dúvida que a conscientização da sociedade quanto a seus direitos e obrigações no que se refere à gestão dos recursos naturais foi uma das mais importantes avanços propiciados pela prática da AIA.

Aumentar e ampliar a efetividade da participação na tomada de decisão é entretanto um desafio para os próximos anos.

De acordo com Milaré (1998) o Conama disciplinou a realização de audiências públicas previstas na Resolução n.001/86, abrindo importante canal para a participação comunitária na aferição do conteúdo dos Estudos de Impacto Ambiental.

Dias (2001) aborda que dentre as várias formas de envolvimento, destacam-se a consulta e a participação que, mesmo sendo freqüentemente empregadas como sinônimos, guardam diferenças importantes relativas ao nível de controle que o público detém sobre o processo. Na consulta, o objetivo maior é ouvir o público; na participação, o pressuposto é de que o público tenha uma fatia do poder de decisão. 
Ortolano $^{2}$ citado por Dias (1997) destaca os principais objetivos que podem ser atingidos por meio da participação pública no processo de AIA:

- aprimorar decisões com potencial de causar impactos em comunidades ou no meio ambiente;

- possibilitar aos cidadãos a oportunidade de se expressar e de ser ouvidos;

- possibilitar aos cidadãos a oportunidade de influenciar nos resultados;

- avaliar a aceitação pública de um projeto e acrescentar medidas mitigadoras;

- desarmar a oposição da comunidade ao projeto;

- legitimar o processo de decisão;

- atender requisitos legais de participação pública;

- desenvolver mecanismos de comunicação em duas vias, entre o proponente do projeto e os cidadãos para identificar as preocupações e valores do público; fornecer aos cidadãos informações sobre o projeto; informar os responsáveis pela decisão sobre alternativas e impacto do projeto.

No contexto do processo de AIA, a participação pública ocorre, geralmente, vinculada à etapa de análise técnica e decisão, embora algumas jurisdições busquem o envolvimento do público também em outras etapas, em especial a triagem e a preparação dos termos de referência. Os mecanismos mais largamente adotados são as audiências públicas, que apresentam severas limitações, como as enumeradas por Sánchez (1999):

- favorece um clima de confronto;

- representam um jogo de soma nula;

- dão margem à manipulação por aqueles quer têm mais poder econômico ou maior capacidade de mobilização;

- ocorrem muitos tarde no processo de AIA quando muitas decisões importantes sobre o projeto já foram tomadas;

\footnotetext{
22 Ortolano L. Environmental regulation and impact assessment. New York: John Wiley, 1997. 1v.
} 
- a maior parte do público dispõe de pouquíssima informação sobre o projeto e seus impactos e os processos de informações pública que deveriam precedê-la são deficientes;

- $\quad$ os tomadores de decisão usualmente não estão presentes;

- uso freqüente de argumentos tecno-científicos num contexto político em que a "verdade científica" não pode ser verificada (Parenteau, ${ }^{3}$ citado por Sánchez, 1999);

- uso freqüente de argumentos jurídicos tentando invalidar ou tornar não legítimas decisões tomadas anteriormente ou a serem tomadas.

\subsubsection{A implantação de grandes projetos, deve propiciar uma compensação ambiental}

Para os consultados, $57,14 \%$ afirmam que na implantação de grandes projetos nem sempre tem sido liberados os recursos e corretamente aplicados, enquanto que $3,57 \%$, dizem o contrário; 32,14\% não tem informações referentes a esse assunto, (Figura 20).

Isto entra em conflito com a legislação ambiental onde os Estudos de Impacto Ambiental devem apresentar uma proposta de aplicação em Unidade de Conservação de no mínimo $0,5 \%$ do total do investimento do projeto, preconizado na Resolução 002/96 CONAMA, como forma compensatória aos danos ambientais decorrentes da implantação dos empreendimentos. $\mathrm{O}$ que ocorre em algumas vezes, é que o órgão ambiental não aplica o recurso em áreas próximas ao projeto.

No caso do empreendimento usado como estudo de caso, e função da localização do Projeto Sossego, estar contígua à Floresta Nacional de Carajás, a SECTAM solicitou à MSS, que apresentasse uma proposta de aplicação de no mínimo $0,5 \%$ do total do investimento do projeto, preconizado na Resolução CONAMA 002/96, como forma compensatória aos danos ambientais decorrentes da implantação do empreendimento, além de medidas mitigadoras que visem a preservação/conservação da FLONACA.

\footnotetext{
${ }^{3}$ Parenteau, R. Public participation in environmental decision-making. Montreal: Federal Environmental Assessment and Review Office, 1998. IV.
} 
Foi apresentada uma proposta ao órgão ambiental intitulado "Plano de Aplicação da Percentagem de Compensação Ambiental do Projeto da Mineração Serra do Sossego/Pará (Protocolo SECTAM 2001 - 9958 em 16/01/01)" para implantação de uma Reserva Ecológica, e outras medidas de compensação ambiental, tais como desenvolvimento de pesquisas de reabilitação e implantação de nichos para a fauna, e o enriquecimento ambiental. $\mathrm{O}$ objetivo desta área é a preservação da biodiversidade, com manutenção dos recursos naturais, fornecimento de sementes e refúgio da fauna nativa, além de se prestar para a educação ambiental.

A área escolhida, apresentada-se constituída por floresta alta, representando a vegetação original primitiva da região. Situa-se na fração sul da portaria de lavra, nas proximidades da usina de beneficiamento e da área administrativa. Reparte-se em duas frações de mata, somando-se ao todo 304 hectares. Além destas áreas a MSS aplicaria cerca de $\mathrm{R} \$ 5.000 .000,00$ na restauração de áreas degradadas que não seriam ocupadas.

Esta área de proteção ambiental selecionada, não pode ser definida como de "preservação", por serem dimensões muito reduzidas. Seriam certamente áreas de conservação, sem dúvida importantes, principalmente se sua localização permitir que com reflorestamentos sejam ligadas e incorporadas a Flonaca após o término da lavra.

Até a presente data o órgão ambiental ainda não se posicionou, quanto à proposta da empresa. Na realidade existe um impasse entre a SECTAM e o IBAMA, a respeito da questão, quanto à aplicação dos recursos e a quem seriam repassados.

Como a FLONACA está numa área próxima à do empreendimento, o IBAMA se pronunciou que deveriam ser incluídas no Parecer Técnico da SECTAM, algumas considerações a respeito da contigüidade da Unidade de Conservação

De acordo com a lei sobre Unidades de Conservação, o montante de recursos a ser destinado pelo empreendedor para esta finalidade não pode ser inferior a meio por cento dos custos totais previstos para a implantação de grandes empreendimentos, sendo o percentual fixado pelo órgão ambiental licenciador, de acordo com o grau de impacto causado pelo empreendimento. 


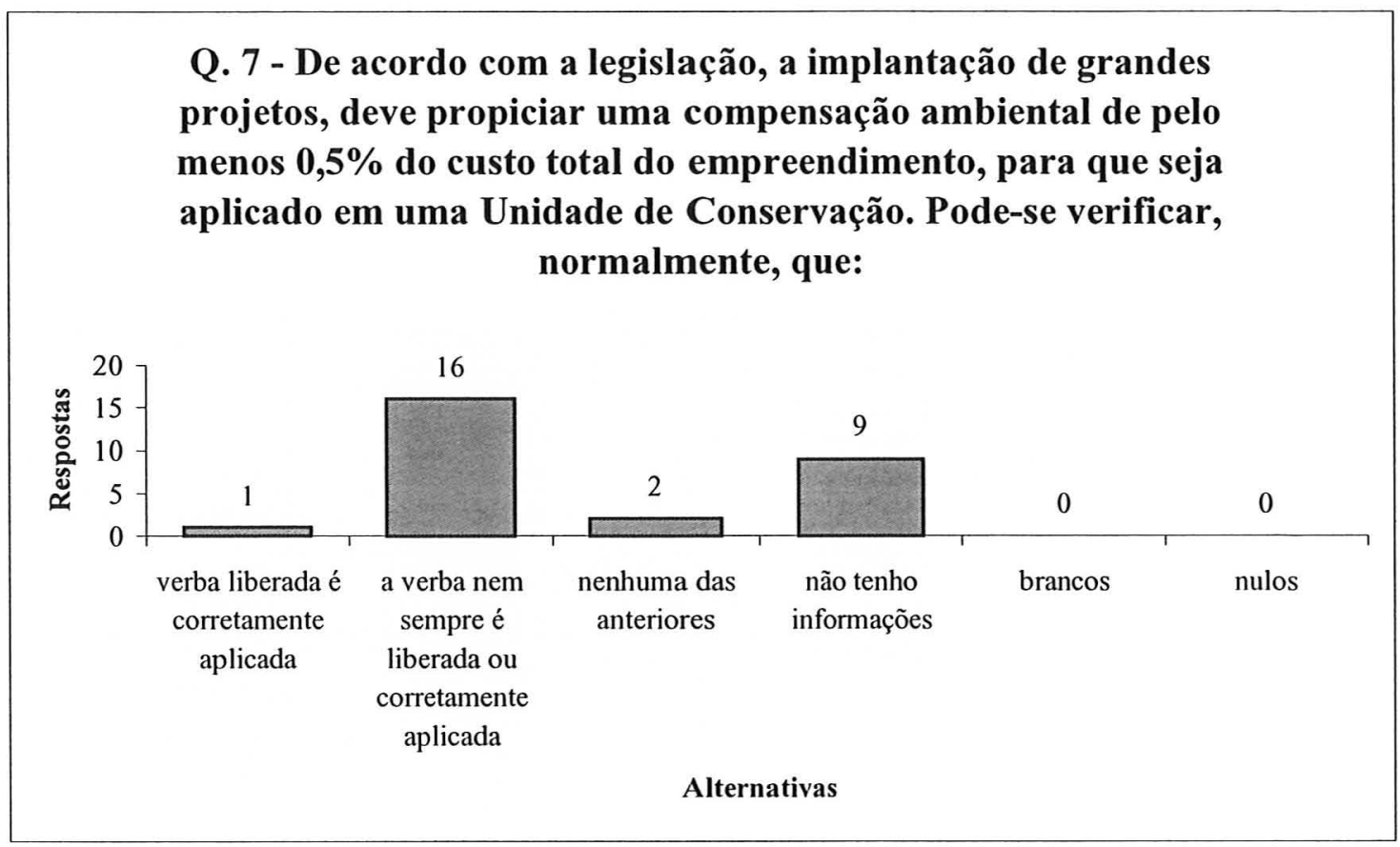

Figura 20 - Compensação ambiental para Unidades de Conservação

\subsubsection{Os levantamentos socioeconômicos para os EIA/RIMA}

Em decorrência dos impactos que serão causados pela implantação do empreendimento, serão abordados vários aspectos no meio socioeconômico que afetarão diretamente a vida da população.

Uma questão importante, refere-se ao levantamento socioeconômico para o EIA/RIMA; o que esta ocorrendo é que na Amazônia os estudos ambientais neste item específico têm se apresentado normalmente frágil, pois maiores problemas oriundos dos grandes projetos estão intimamente ligados à área socioeconômica.

Na maioria dos empreendimentos o problema apresenta-se desde sua a concepção, onde as propostas de inserção social do projeto no município, são pensadas posteriormente.

No EIA/RIMA da MSS, uma das principais falhas reside no levantamento socioeconômico, que foi insuficiente diante da magnitude dos impactos sociais que irão ocorrer na região. Ele não deu elementos para uma análise criteriosa dos problemas oriundos da implantação do projeto. O órgão ambiental deveria ter solicitado ao 
empreendedor a realização de outros estudos para poder avaliar corretamente os impactos ambientais do empreendimento e para melhor embasamento da decisão a ser adotada quanto a cada uma das licenças a serem expedidas.

O órgão ambiental pode em qualquer fase do licenciamento solicitar outros estudos ambientais, para subsidiar e balizar a sua decisão.

Uma das primeiras falhas na análise do EIA/RIMA da MSS, foi a não solicitação de estudos complementares para a construção de uma linha de transmissão de $230 \mathrm{Kw}$, a qual foi considerada dentro da área de influência indireta do empreendimento e não na área de influência direta o que seria o correto, e que portanto, deveria ser objeto de um estudo mais aprofundado, mesmo considerando que as áreas onde ela será implantada encontram-se totalmente descaracterizadas, mostrando ai um conflito quanto à definição de AII e ADA.

No entendimento do órgão ambiental (SECTAM), apesar de fazer considerações, no seu parecer técnico sobre o aprofundamento dos estudos para o traçado da linha de transmissão, até a presente data não foi apresentado pela empresa nenhum estudo complementar a esta solicitação. A Resolução Conama 001/86, no seu artigo 2. ${ }^{\circ}$, define a necessidade de elaboração de EIA/RIMA de acordo com a amplitude do empreendimento, aponta: linhas de transmissão de energia elétrica acima de $230 \mathrm{KW}$.

Entretanto deve-se salientar que em outros empreendimentos, linhas de transmissão de $230 \mathrm{Kw}$ têm merecido a realização de EIA/RIMA.

Outro ponto conflitante é a definição que foi dada para as áreas de estudo do EIA/RIMA da MSS, que as definiu em três níveis como Área Diretamente Afetada (ADA) Área de Influência Indireta (AII) e de Entorno (AE) do empreendimento. No EIA os municípios de Canaã dos Carajás e Parauapebas foram definidos com AII. Entende-se que os mesmos deveriam ser considerados como área de influência direta, pelo fato dos municípios estarem próximos à área do projeto; também por fazerem parte da bacia hidrográfica na qual está inserido o projeto e possivelmente serão os municípios que serão passíveis de efetivas alterações.

O município de Canaã dos Carajás absorverá diretamente várias das alterações socioeconômicas proporcionadas pela instalação do empreendimento em seu território. 
Moradores e instituições públicas e privadas, terão seu cotidiano transformado tanto no que diz respeito à sua infra-estrutura básica quanto aos seus aspectos socioeconômicos, culturais e ambientais.

Por um lado, a significativa elevação de sua arrecadação tributária e o amplo crescimento da demanda sobre seus setores produtivos, principalmente comércio e serviços e, por outro lado, sobrecarga de sua estrutura urbana, saneamento básico e ordenamento espacial, de sua capacidade de atendimento nos setores de educação e saúde, possibilitando ao município os elementos necessários, se bem planejados, de se alcançar a um novo patamar de desenvolvimento.

Inicialmente, a proximidade entre a área de implantação do empreendimento e a cidade de Canaã dos Carajás faz supor que este poderá vir a atrair um contingente populacional, dadas às oportunidades de emprego e negócios que um empreendimento desse porte gera. É preciso considerar, ainda, que as carências regionais e o seu grande contingente de profissionais do garimpo deverão reforçar essa tendência.

Soma-se a esse quadro a necessidade do desenvolvimento de ações que possibilitem ao município se preparar para capitalizar positivamente, o incremento em sua dinâmica econômica e urbana que se dará quando da instalação do empreendimento e que precisará ser assegurada após seu fechamento.

Os estudos não informaram sobre a situação de segurança nos municípios, não existem dados sobre os índices de criminalidade, embora sejam áreas propicias à ocorrência de delitos na atividade garimpeira e conflitos pela posse da terra como já ocorridos em Eldorado do Carajás.

As omissões dessas informações prejudicaram a compreensão quanto ao nível de tensão nos municípios e a qualidade do serviço de segurança oferecido aos cidadãos.

No item análise dos impactos ambientais foram indicados os métodos, técnicas e critérios adotados para a identificação, quantificação e interpretação dos prováveis impactos ambientais da implantação, operação e desativação das atividades do empreendimento. 
Foi feita uma caracterização da qualidade ambiental futura da área de influência do empreendimento, comparando as diferentes situações de adoção do projeto, plano ou programa e de suas alternativas, bem como a hipótese de sua realização.

Os critérios de avaliação de impactos ambientais, foram adotados pela empresa de consultoria ambiental, que segundo o EIA/RIMA, levaram em consideração as leis e resoluções pertinentes, em especial a Resolução 01/86.

Os critérios não foram mostrados, no aspecto socioeconômico com transparências e os prováveis efeitos da implantação, operação e desativação das atividades do empreendimento sobre: a saúde, a segurança e o bem estar da população; as atividades sociais e econômicas; a biota; as condições estéticas e sanitárias do meio; as qualidades dos recursos ambientais, ficaram frágeis, no tocante aos impactos sócio-ambientais do empreendimento.

A análise dos impactos ambientais significativos do projeto no aspecto socioeconômico, principalmente no que diz respeito à etapa de implantação, não aparece na matriz de impactos, que é a eliminação de empregos na etapa de construção da planta de concentração; ela só aparece na etapa de desativação, é extremamente preocupante a forma como é omitido este fato.

O EIA/RIMA descreve que no pico da obra na etapa de implantação serão gerados um número maior empregos sem qualificação, cerca de 3.000 empregos, perdurando em torno de 30 (trinta) meses, ou 2,6 (dois anos e seis meses), que trabalharão em obras (terraplenagem, construção civil, montagens eletromecânicas e serviço de apoio). Esta é uma contratação temporária, tempo previsto para a implantação do projeto que é de 04 anos, com obras para três anos.

No primeiro ano estima-se a alocação de cerca 1.500 pessoas, no segundo $3.000 \mathrm{e}$ no terceiro 1.000. De acordo EIA/RIMA, os trabalhadores com vocação e maior potencial, eventualmente poderão ser treinados para a etapa operacional do empreendimento.

No EIA, é demonstrado que não ocorrerá aumento da população de trabalhadores, em um nível acima da capacidade de absorção do meio, onde potencialmente poderia haver uma sobrecarga das infra-estruturas urbanas. Neste sentido a avaliação do Estudo 
acima mencionado, falha ao omitir um dos maiores impactos que ocorrerá em decorrência do projeto na região e que na matriz de impactos na fase de implantação não aparece.

Estes são um dos primeiros impactos que irão ocorrer na região, constituindo-se em um grande contingente populacional, que será atraído pelo empreendimento provocando uma sobrecarga na capacidade de atendimento das estruturas urbanas, e de serviços no município.

Esse é um dos principais impactos, o qual aparentemente, no início do projeto, é um impacto positivo, mas logo depois ele se torna um impacto de alta intensidade e negativo, uma vez que haverá demissão dos empregados. O EIA/RIMA apresenta a princípio diretrizes muito fracas para resolver a questão, como absorver um contingente de desempregados.

$\mathrm{Na}$ etapa operacional do empreendimento serão gerados 667 empregos diretos. Pode-se prever segundo o EIA/RIMA a criação de cerca de 1.500 empregos indiretos associados à prestação de serviços diversos tais como segurança patrimonial, restaurante, transporte de concentrado, limpeza e outros não relacionados ao processo produtivo tais como empregos no comércio.

Os impactos que serão gerados na organização social e econômica dos Municípios de Canaã dos Carajás e, em menor intensidade, de Paraupebas foram considerados de intensidade alta com conseqüências graves em virtude da oferta de 3.000 empregos diretos, seguida de dois períodos de dispensa em massa.

Segundo Dias (2001) em relação ao aumento de empregos vale destacar que a atividade de mineração gera um número reduzido de empregos quando comparada a outras atividades industriais com valor de investimentos equivalente.

Por mais eficiente que seja o Programa de Treinamento e Habilitação Profissional para a comunidade local, certamente haverá intensa migração para Canaã dos Carajás, sendo possível que a população da cidade (10.922 hab.) venha a dobrar em curto espaço de tempo.

Ao lado deste problema, quando estiverem concluídas as obras da Usina de Concentração do Minério e efetivamente ocorrer o início da exploração minerária, cerca 
de 1.200 vagas serão extintas, provocando graves desequilíbrios sociais na comunidade, os quais só poderão ser mitigados com um eficiente plano socioeconômico que possa trazer recursos municipais, estaduais, federais e certamente internacionais, além de empresários interessados em aumentar nesta época o potencial de oferta de empregos.

Esta situação vai se repetir de forma menos grave no esgotamento dos recursos minerários e encerramento do empreendimento, com a dispensa em massa de 667 empregados.

Por outro lado apresenta-se o Programa de Compensação, Inserção e Comunicação Social, que não apresenta propostas concretas, não evidenciando um diagnóstico socioeconômico e não oferecendo as necessárias alternativas para a solução dos graves problemas que serão verificados com imediato afluxo de contingente de trabalhadores, demanda emergente de serviços públicos, crescimento difícil controle da comunidade urbana, seguidos de duas etapas de dispensa em larga escala de trabalhadores.

A outra proposta do projeto para minimizar os impactos socioeconômicos, é a Proposta de Trabalho que traz as diretrizes para a elaboração do Plano de Desenvolvimento Sustentável - PDS; tem como objetivo central o estabelecimento de estratégias e a execução de ações que permitam assegurar o desenvolvimento sustentável daquele município, de forma a possibilitar que sua população venha a maximizar e usufruir o surto de crescimento econômico que se prenuncia com a instalação do Projeto Sossego, não apenas em função da oferta imediata de novas oportunidades de emprego e renda.

A proposta do desenvolvimento sustentável, embora não esteja isenta de ambigüidades, tem sido amplamente desejável. Sabe-se que seu alcance implica no equilíbrio entre as dimensões sociais, econômicas e ambientais do desenvolvimento. Porém quando a base produtiva de economia está assentada no uso de recursos exauríveis, como será o caso de Canaã dos Carajás, para que se efetive a sustentabilidade deve se considerar duas perspectivas: a "intrageracional", no sentido de que a atividade deve minimizar os impactos sócio-ambientais das gerações presentes e a "intergeracional" no sentido de que deve ser capaz de gerar um permanente fluxo de rendimentos, às gerações futuras, objetivando garantir e elevar o nível de bem-estar 
social quando a atividade mineradora se exaurir (Auty \& Warhurst, 1993). Portanto, pensar na sustentabilidade do desenvolvimento de regiões mineiras significa atentar para estas duas frentes, quais sejam: minimizar as externalidades das atuais gerações e potencializar o bem-estar das futuras gerações, a partir do uso produtivo das rendas geradas pela riqueza mineral que foi exaurida.

Certamente estas alternativas devem ser estudadas por uma equipe multidisciplinar, com ações interdisciplinares, prováveis e inicialmente baseadas na pecuária de corte e de leite que na atualidade representam a base econômica do município.

Entretanto, sabe-se bem que a pecuária, por mais incrementada que seja com melhoramento e recuperação de pastagens, além do melhoramento genético do rebanho, caracteriza-se como uma atividade que gera poucos empregos.

Uma diretriz possível estaria na verticalização da atividade, promovendo cooperativas, industrializando o leite e seus derivados, implantando-se frigoríficos, matadouros e curtumes, além de industriais que tenham o couro e a carne como matérias primas.

A busca por alternativas de ofertas de empregos poderá ainda ter como base a agricultura, com a produção de grãos, a fruticultora tropical, e a zootecnia de peixes e de animais silvestres.

A recuperação de áreas degradadas no entorno do empreendimento, também poderia oferecer muitos empregos em viveiros de mudas e tratos silviculturais.

É possível que a biodiversidade da Floresta Nacional de Carajás (FLONACA) permita, após as pesquisas indispensáveis, oferecer alternativas de extrativismo de resinas, frutos silvestres e plantas medicinais.

A organização e integração dos serviços urbanos também serão uma grande fonte de empregos com o crescimento urbano que fatalmente ocorrerá. Este incremento socioeconômico deverá ser muito planejado e disciplinado para que não se avolumem os problemas de saúde já existentes, juntamente com os povos patógenos e doenças transmissíveis que inevitavelmente chegarão, além da pressão sobre os recursos naturais, principalmente os hídricos, o que poderia destruí-los em curto prazo. 
$\mathrm{Na}$ área socioeconômica reside o maior desafio para que este empreendimento da MSS se enquadre no desenvolvimento regional do Pará, esperando-se que seja sustentável.

O aspecto socioeconômico suscita algumas observações que se reputam como pertinentes e relevantes. A criação de empregos, se acarreta impacto positivo na implantação do projeto, enseja a adoção de projetos e outras iniciativas que atenuem os desdobramentos advindos da redução e eliminação de postos de trabalho previstas às etapas operacionais e de fechamento do empreendimento.

Acresce que o inchaço populacional propiciará desdobramentos indesejáveis na área quanto à segurança, como aumento da criminalidade e violência, surgimento de favelas, favorecimento à prostituição infanto-juvenil, moradias insalubres, incidência de moléstias e falência dos serviços públicos; enfim, desenha-se um panorama de miséria e exclusão social.

Daí a necessidade na tomada de providências alusivas à capacitação dos recursos humanos, estímulo à abertura de microempresas, ordenação da informalidade, políticas sociais da habitação, saneamento, educação, conscientização ambiental, e demais ações de ordem pública e de responsabilidade social da MSS, que, efetivamente contribua para a consolidação da democracia, via pleno exercício da cidadania.

A correta compreensão e avaliação dos impactos de um empreendimento sobre o meio antrópico na fase de elaboração dos estudos de impacto ambiental permite não somente a proposição de medidas mitigadoras e de compensação adequadas, como podem induzir alterações no próprio projetado, evitando situações futuras de solução muito mais difícil e onerosa (Dias, 2001).

Em recente pesquisa Silva (1999), demonstra que as indústrias do ramo extrativomineral instalada no Pará têm realizado muito mais dispêndios ao meio ambiente do que à questão social. Calculado para o ano de 1998, o coeficiente de gastos sobre o faturamento foi de $1,2 \%$ para os meios físico e biológico $0,2 \%$ para o social. $O$ estudo demonstra também que os fatores de pressão que contribuem para essa atitude ambiental pró-ativa, por partes das empresas mineradoras, são: 1) localização na Amazônia; 2) direcionamento ao mercado exportador; 3) entrada em operação no momento em que a 
legislação ambiental brasileira já estava implementada; 4) custos ambientais que não comprometam a rentabilidade da empresa; e 5) adoções de tecnologia ambiental de baixo custo, que tem sido acelerada nos últimos 10 anos.

Portanto, o grande desafio da região é melhorar seus indicadores socioeconômico para garantir um melhor nível de bem-estar tanto às gerações atuais quanto às futuras. Um empreendimento que, de fato, incorpore os conceitos de Desenvolvimento Sustentável e responsabilidade social não pode e nem deve menosprezar a questão socioeconômica do entorno de sua atividade.

Mesmo considerando o extrativismo mineral como um grande fonte de receitas são necessários ponderar seus impactos. O processo extrativo está intimamente associado à degradação do ambiente, o que, na ausência de políticas rígidas de proteção ambiental, os custos ambientais podem chegar a ser maiores que os benefícios esperados, haja visto que a valorização dos recursos no mercado internacional leva, necessariamente, a uma excessiva exploração, causando uma rápida degradação ambiental.

Ressalta-se que na mineração industrial, os danos ambientais diretos do processo de exploração são relativamente controlados e minimizados pelos próprios empreendimentos, que, em geral, adotam métodos eficientes de extração do minério e promovem a recuperação das áreas exploradas. Contudo, os impactos secundários desses projetos não são perfeitamente identificados, portanto de difícil controle. As populações envolvidas pelas suas obras de construção procuram instalar-se no entorno do próprio projeto e lá permanecem sem assistência e organização urbana, sem empregos, sem usufruir os benefícios que poderiam ser gerados. Esses projetos normalmente necessitam de grandes contingentes de mão-de-obra para instalação, mas dispensam esses trabalhadores tão logo são concluídas as obras de construção físicas do projeto e iniciada a sua produção em escala real.

É fundamental implementar diretrizes viabilizadoras do desenvolvimento sustentável, devendo as atividades produtivas balizar-se pelo respeito ao meio ambiente, de modo a assegurar sua sustentabilidade sem, contudo, criar obstáculos ao desenvolvimento econômico. 
Para o estudo de caso analisado, a avaliação do meio antrópico reflete bem os resultados alcançados com os questionários, onde $60,71 \%$, dos especialistas afirmam que os diagnósticos não têm sido bem executados com boa qualidade, enquanto que $21,43 \%$, dizem o contrário (Figura 21).

Ainda segundo os consultados $39,29 \%$ afirmam que a redução do tempo e dos recursos financeiros tem contribuído para a fragilidade dos estudos, e apenas 3,57\% acreditam o contrário; entretanto 32,14\% responderam nenhumas das anteriores; $17,86 \%$ não tem informações quanto ao tema, apresentados de acordo com a (Figura 22).

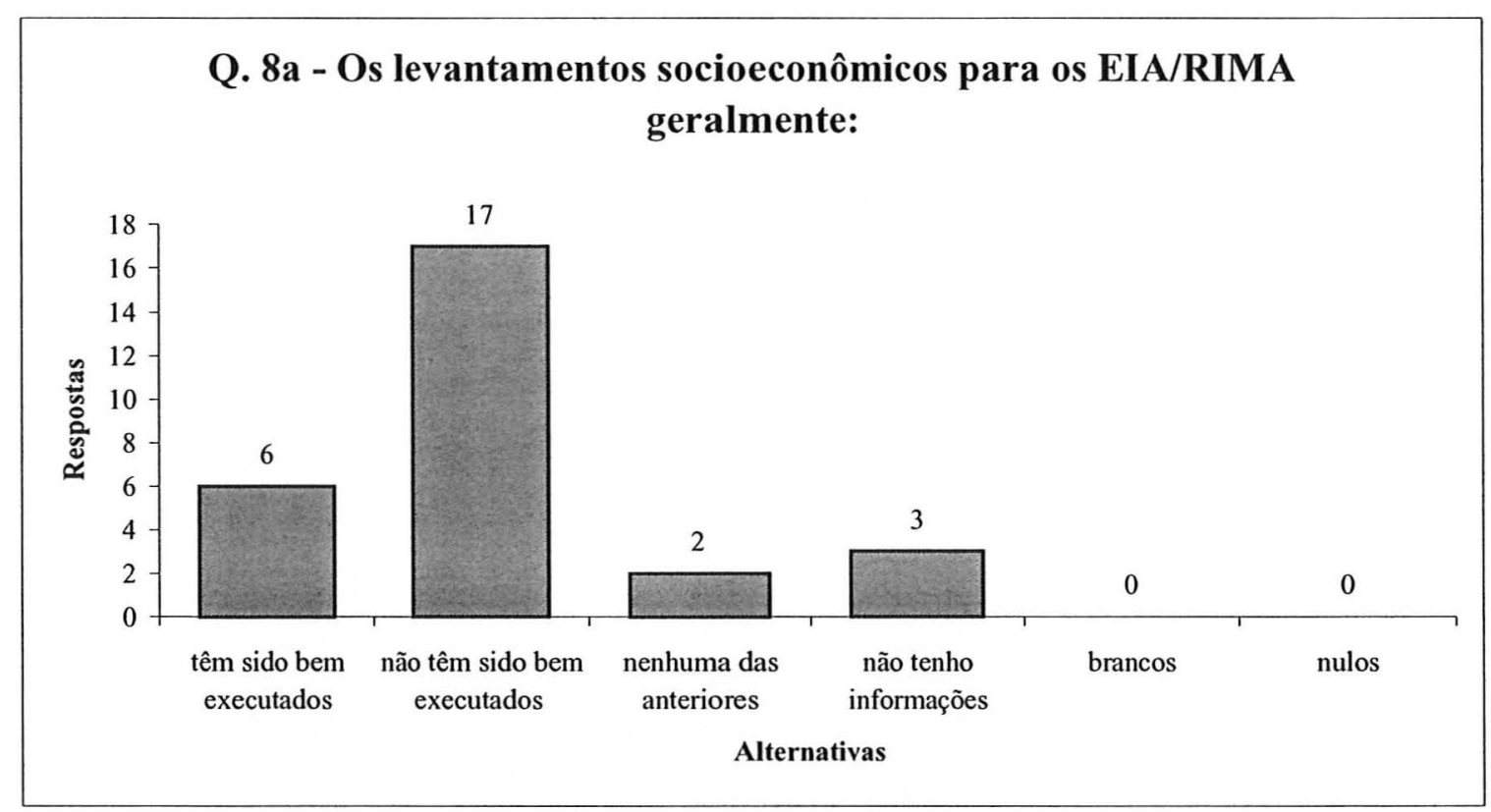

Figura 21 - Levantamento Socioeconômico para EIA/RIMA 


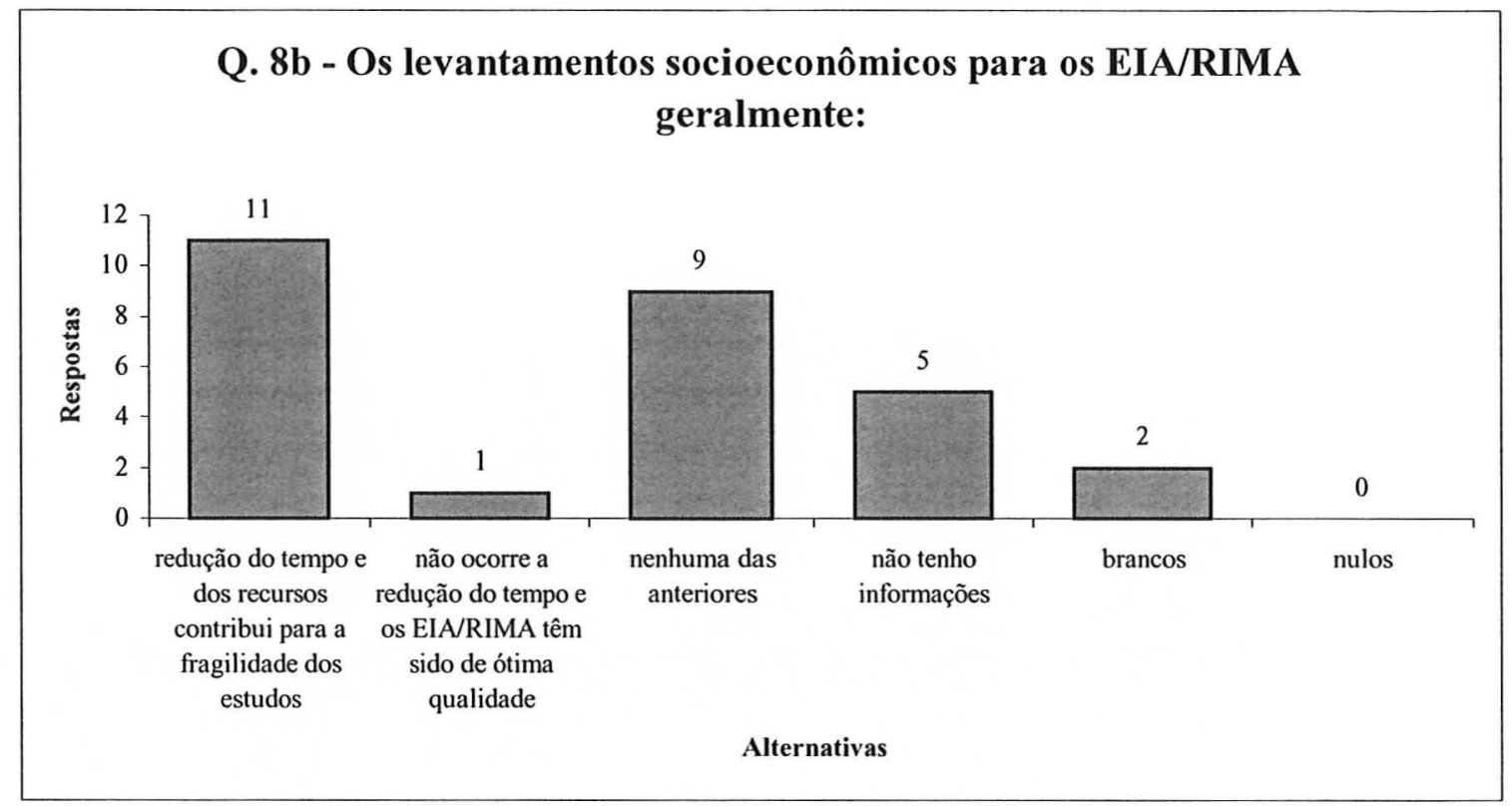

Figura 22 - Os EIA/RIMA e o levantamento socioeconômico

\subsubsection{Os acompanhamentos da execução das medidas mitigadoras, compensatórias dos monitoramentos e recuperação de áreas degradadas}

Outro problema refere-se ao acompanhamento da execução das medidas mitigadoras, na verificação do cumprimento das exigências das licenças, dos programas de monitoramento e dos programas de recuperação. O órgão ambiental vem encontrando dificuldades em atender este requisito, em virtude dos recursos financeiros e de um reduzido número de técnicos existente na SECTAM, principalmente levando-se em consideração o tamanho do Estado do Pará.

Este dado vem corroborar com os problemas encontrados nos órgãos ambientais ou seja $64,29 \%$ dos consultados afirmam que o corpo técnico dos órgãos ambientais não tem efetuado o acompanhamento das medidas mitigadoras em decorrência do reduzido número de técnicos capacitados, enquanto que 14,29\% dizem o contrário, (Figura 23).

Ainda de acordo com os especialistas, 75,00\% afirmam que a falta de recursos dos órgãos ambientais tem impedido o acompanhamento das medidas mitigadoras após a fase de licença de instalação, enquanto que 7,14\% dizem o contrário (Figura 24). 
Tendo em vista a estruturação do Sistema de Avaliação de Impacto Ambiental no Brasil num quadro jurídico-institucional pautado na legislação norte-americana (que utiliza os EIA/RIMA como instrumentos de planejamento), mas cuja prática é baseada na abordagem francesa (que utiliza os EIA/RIMA como documentos de licenciamento ambiental), recai sobre as medidas mitigadoras uma parte muito importante de um Estudo de Impacto Ambiental executado em nosso país.

Realmente, cabe às medidas mitigadoras e compensatórias oferecerem o contraponto às ações impactantes realizadas ou desencadeadas no meio ambiente.

No que concerne às técnicas de monitoramento e gestão dos impactos sobre o meio antrópico, Sánchez (1993) destaca a importância dos indicadores sociais, cujo uso, todavia, não está ainda tão desenvolvido como o de outros indicadores ambientais.

Com relação à mitigação dos impactos sobre o meio antrópico, as medidas mitigadoras que podem ser adotadas variam desde as técnicas, que reduzem os impactos sobre o meio físico e biótico, evitando as conseqüências no meio antrópico, até as que interferem diretamente na questão socioeconômica ou cultural.

Em muitos casos, as medidas mitigadoras dependem de ações do poder público, ao qual os proponentes do projeto devem fazer gestões e, quando possível, participar da solução dos problemas gerados pelo empreendimento. É o caso do aumento da demanda por serviços sociais e infra-estrutura que, dependendo da sua magnitude, requer a participação da empresa por meio da construção e hospitais, postos de saúde, escolas, creches etc.

O processo de AIA não se extingue com a aprovação do EIA/RIMA. A etapa do acompanhamento e monitoramento dos impactos constitui-se em atividade técnica permanente do processo de AIA. Tem o objetivo de retroalimentar os sistemas de controle continuamente, visando reduzir impactos preditos ou não previstos na elaboração dos estudos ambientais. O acompanhamento e monitoramento são atividades ou processos que envolvem técnicas de avaliar e prever impacto e de escolher as medidas mitigadoras a serem adequadas na prática do empreendimento. Esta avaliação permanente permite identificar processos e conhecimentos necessários para a adoção de medidas de correções dos desvios ocorridos. 
Se o acompanhamento e monitoramento forem efetivamente realizados para as atividades, seguindo suas diretrizes gerais, o processo de AIA sofrerá uma avaliação permanente que, sem dúvida, servirá para otimizar a eficiência, a eficácia e a efetividade deste instrumento de gestão ambiental. Essa é uma prática já incorporada a ISO 14.000, por exemplo, e para manter-se credenciada, a empresa precisa manter os padrões estabelecidos em seu plano.

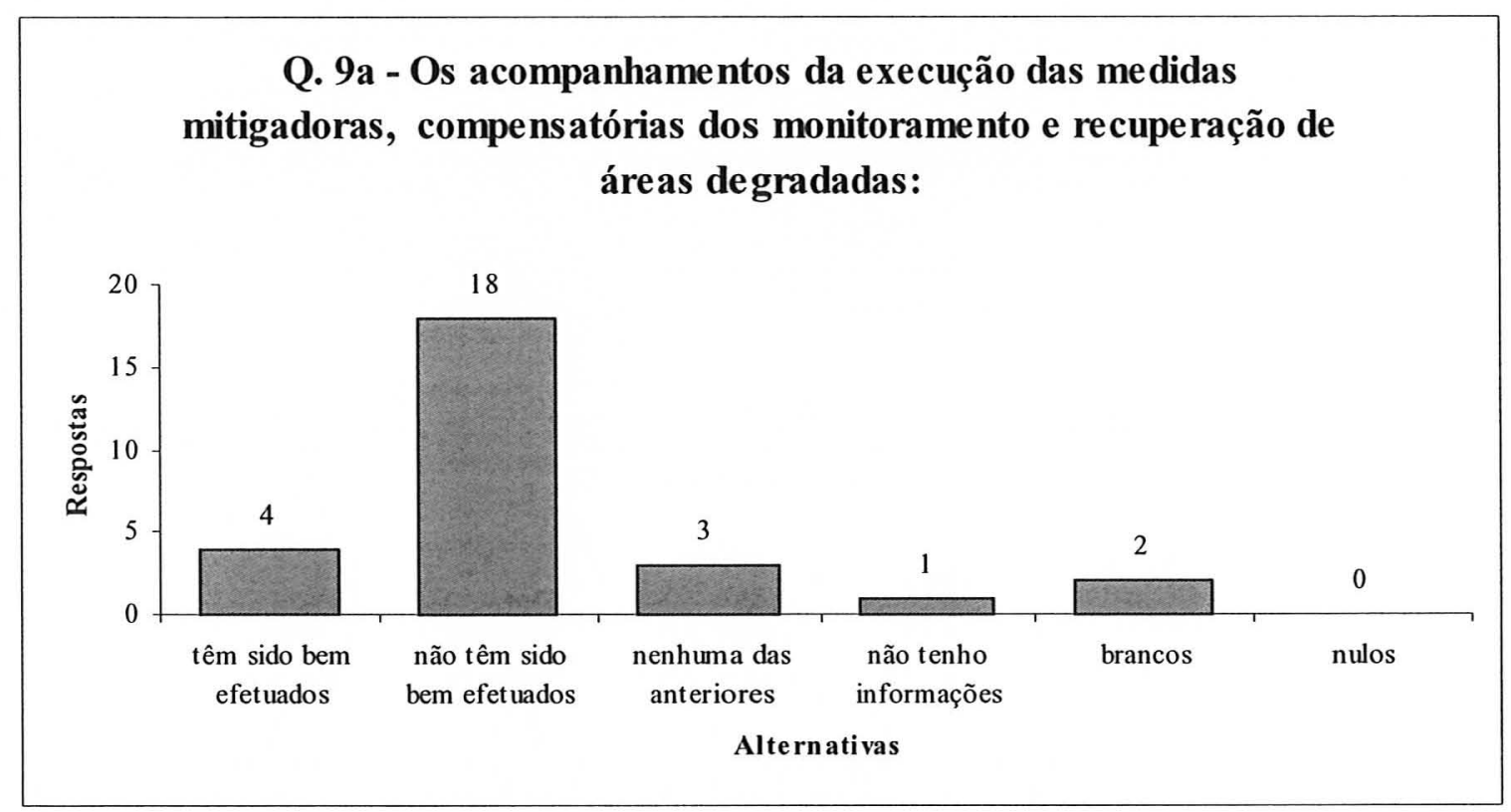

Figura 23 - Acompanhamento e execução das medidas mitigadoras 


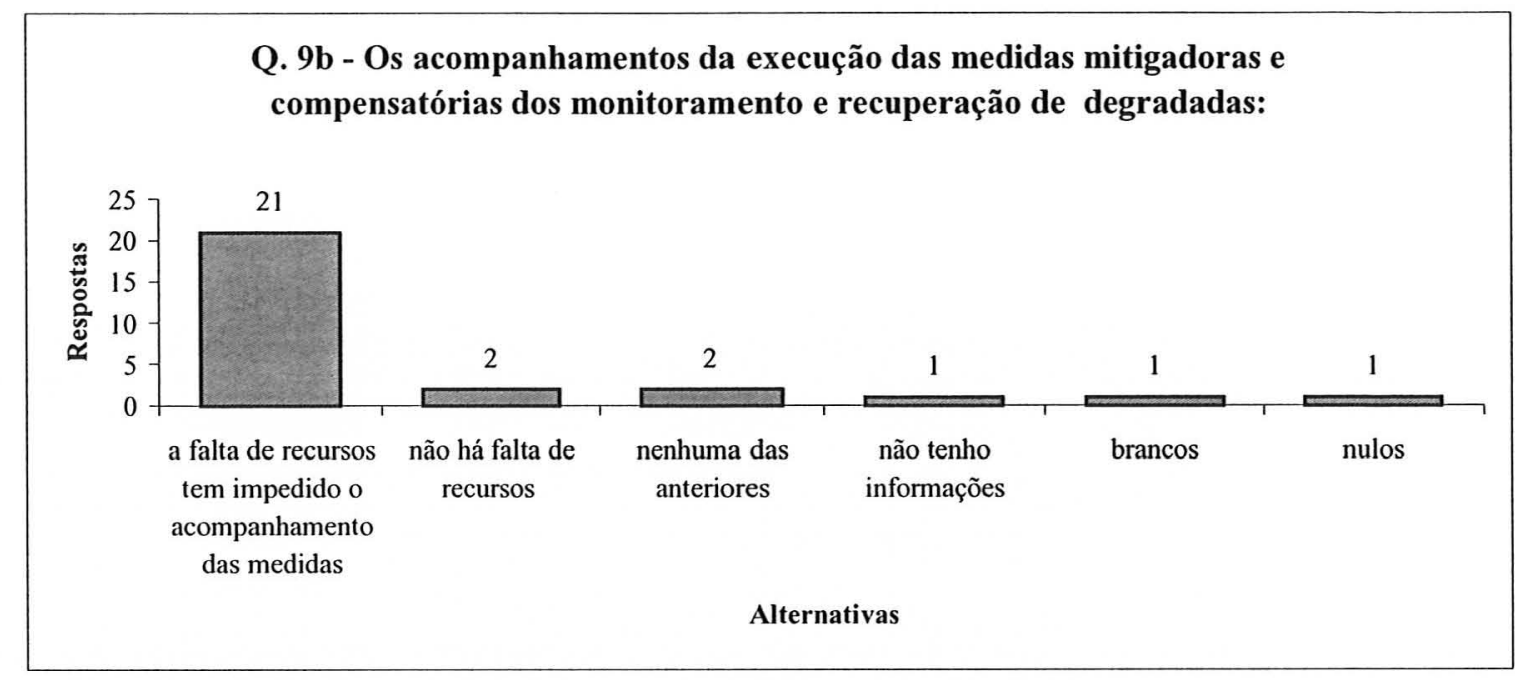

Figura 24 - Acompanhamento das medidas de execução e dos programas de monitoramento

\subsubsection{O conflito de competências em relação ao licenciamento ambiental entre a SECTAM E O IBAMA}

No que concerne ao licenciamento de atividades potencialmente poluidoras cujos impactos ambientais apresentam abrangência regional (que estendem-se para além das fronteiras de um único estado) ou nacional (podem afetar todo o território nacional), demanda a competência supletiva do IBAMA.

Muitos problemas estão ocorrendo neste sentido entre o IBAMA e SECTAM no Estado do Pará, em virtude da competência do licenciamento ambiental de grandes projetos na Amazônia. Isto faz com que os processos fiquem paralisados, e acabem parando no Ministério Público Federal ou Estadual, como foi o caso específico da Hidrovia do Marajó, onde o IBAMA entendeu que o licenciamento ambiental deveria ser feito pelo órgão e não pela SECTAM.

O projeto Hidrovia do Marajó consiste basicamente na implantação de uma via navegável que cruza a ilha de Marajó, da baía do Marajó ao braço sul do rio Amazonas, propiciando uma ligação mais direta entre Belém e Macapá, e facilitando o transporte e a comunicação na parte central da ilha. Para isto o projeto prevê a interligação, por um canal de $32 \mathrm{~km}$, dos rios Atuá e Anajás. A primeira licença prévia foi expedida 15.08.99 
e de instalação em 03.09.99. Desde esta data o projeto está paralisado no Ministério Público Federal, por conta do licenciamento ambiental de outros impeditivos legais.

Com a ligação hidroviária entre os rios Atuá e Anajás (hidrovia do Marajó), na ilha de Marajó, aliado à melhoria das condições de transporte na região, espera-se um melhoria das condições de vida da população e o desenvolvimento econômico e social da região, de forma ordenada e consciente.

Isto vem corroborar com os resultados no qual os especialistas consultados, $64,29 \%$ afirmam que existe conflito quanto ao licenciamento ambiental; enquanto que 14,29\% dizem o contrário; e 14,29\%, não tem informações a esse respeito (Figura 25).

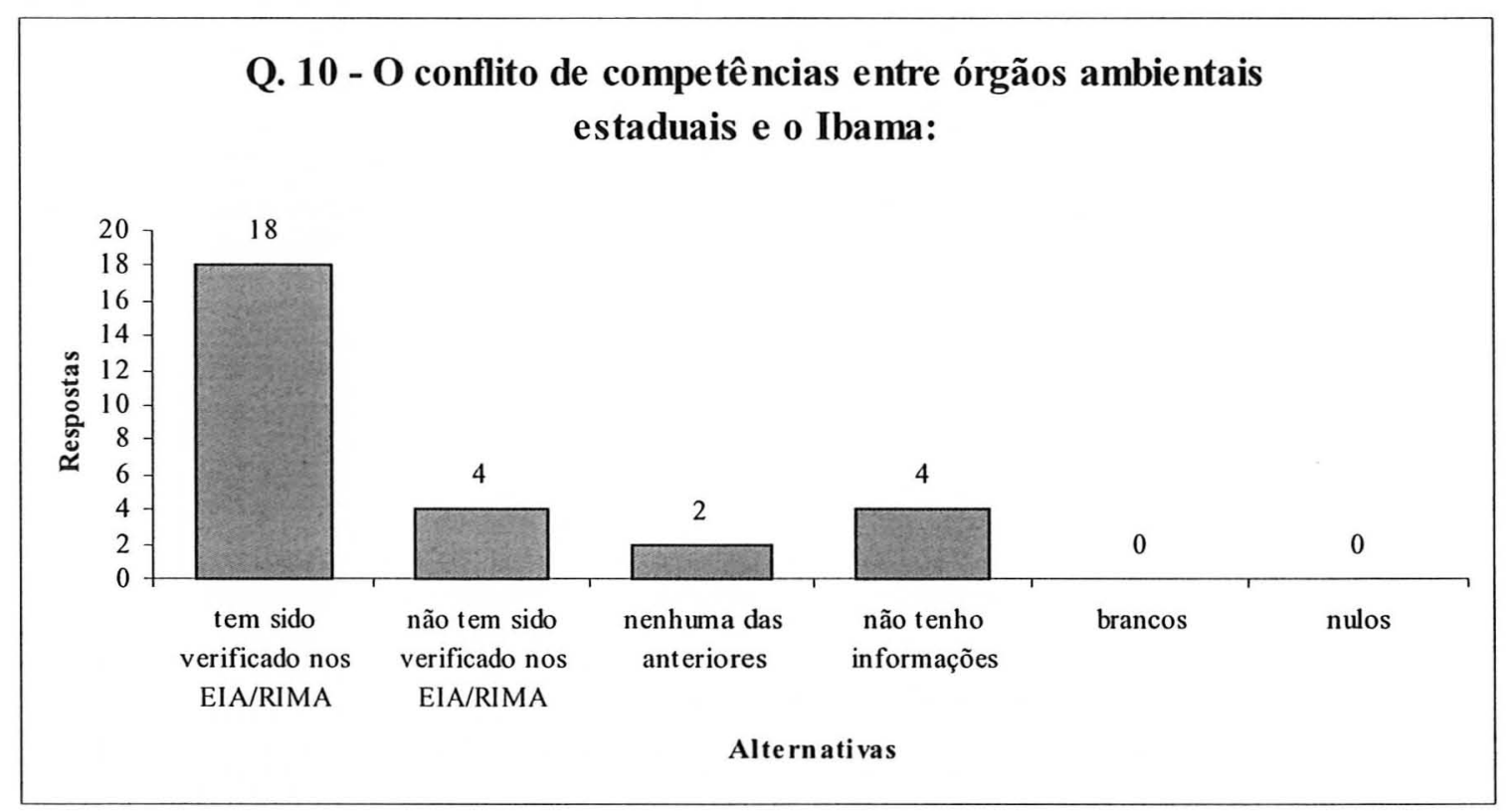

Figura 25 - O conflito quanto ao licenciamento ambiental

\subsubsection{Licença prévia e de instalação}

Segundo (Brito, 1995) um dos maiores avanços da AIA no Brasil está representado pela sua incorporação ao sistema de licenciamento ambiental, o Sistema de Licenciamento de Atividades Poluidoras (SLAP). Esse mecanismo adotado na legislação brasileira evita uma série de dissabores por que passou a sociedade americana nos 
primórdios da aplicação da AIA nos EUA, e que ainda limitam a efetividade do processo em alguns países da Europa. O SLAP foi concebido na FEEMA, órgão de controle ambiental do Estado do Rio de Janeiro, em 1977 e mais tarde adotado em âmbito nacional, como instrumento da política ambiental brasileira expressa na Lei 6.938/81. O decreto 88351/83 que o regulamentou estabeleceu a obrigatoriedade de três licenças consecutivas, as licenças prévias, de instalação e de operação.

Entretanto, apesar dos preceitos legais vigentes, nem todos os estados adaptaram seus sistemas de licenciamento ambiental às exigências da lei, ou o vêm aplicando em desconformidade com os previsto no âmbito federal. Se aplicado corretamente, é a vinculação ao Licenciamento de Atividades Poluidoras (SLAP) que assegura que as conclusões e recomendações do estudo de impacto ambiental sejam adotadas, acompanhadas e monitoradas, pois esses procedimentos já estão perfeitamente regulamentados no âmbito do processo de licenciamento.

Sem a prefeita compreensão e aplicação do SLAP não se pode maximizar o potencial da AIA como instrumento de gestão ambiental. Em muitos estados os estudos de impacto ambiental só são requeridos na fase de licença de instalação, o que contradiz frontalmente com os conceitos da AIA, enquanto instrumento de gestão de caráter preventivo, tão mais efetivo quanto mais cedo for aplicado ao ciclo de planejamento do projeto. Por outro lado, essa prática colide com a Constituição Federal que determina em seu artigo 225, a elaboração do estudo prévio de impacto ambiental, para o licenciamento de obras de grande potencial poluidor. Portanto, se o licenciamento se inicia com a licença prévia obrigatória, deve o EIA ser também requerido nessa fase.

Contam-se os raros casos em que os órgãos ambientais tenham verificado se as recomendações constantes do estudo de impacto ambiental foram efetivamente implantadas, e que venham monitorando a evolução dos impactos ambientais e a eficiência das medidas mitigadoras implantadas.

No estudo de caso da MSS, a licença prévia foi emitida com condicionantes para a próxima fase, após aprovação do EIA/RIMA, vistoria técnica ao local do empreendimento e a realização de uma audiência pública no município de Canaã dos Carajás. Logo depois foi emitida a licença de instalação, após aprovação dos 23 
Programas de Controle Ambiental do projeto, com condicionantes para a próxima fase, sem ter ainda uma definição muito clara das alternativas de aproveitamento da mão-deobra local, após a demissão. Esta função seria do Plano de Desenvolvimento Sustentável; no entanto o documento apresentou apenas um programa de trabalho, onde traz as diretrizes de como será implementado o PDS.

O licenciamento de atividades, efetiva ou potencialmente, degradadoras e/ou poluidoras do meio ambiente, é o principal instrumento oficial administrativo, que dispõem os órgãos e entidades do poder público, constituintes do SISNAMA, para preservar a qualidade do meio ambiente e o equilíbrio ecológico do país. A avaliação de impactos ambientais tem sido utilizada como instrumento complementar ao licenciamento ambiental, encobrindo sua verdadeira finalidade no processo decisório do planejamento de um empreendimento público ou privado.

Para os especialistas consultados, $71,43 \%$ afirmam que as LP e LI têm sido dadas quando eventualmente ainda há dúvidas sobre a possibilidade de implantação do empreendimento; enquanto que 10,71\% dizem o contrário; conforme mostra na (Figura 26).

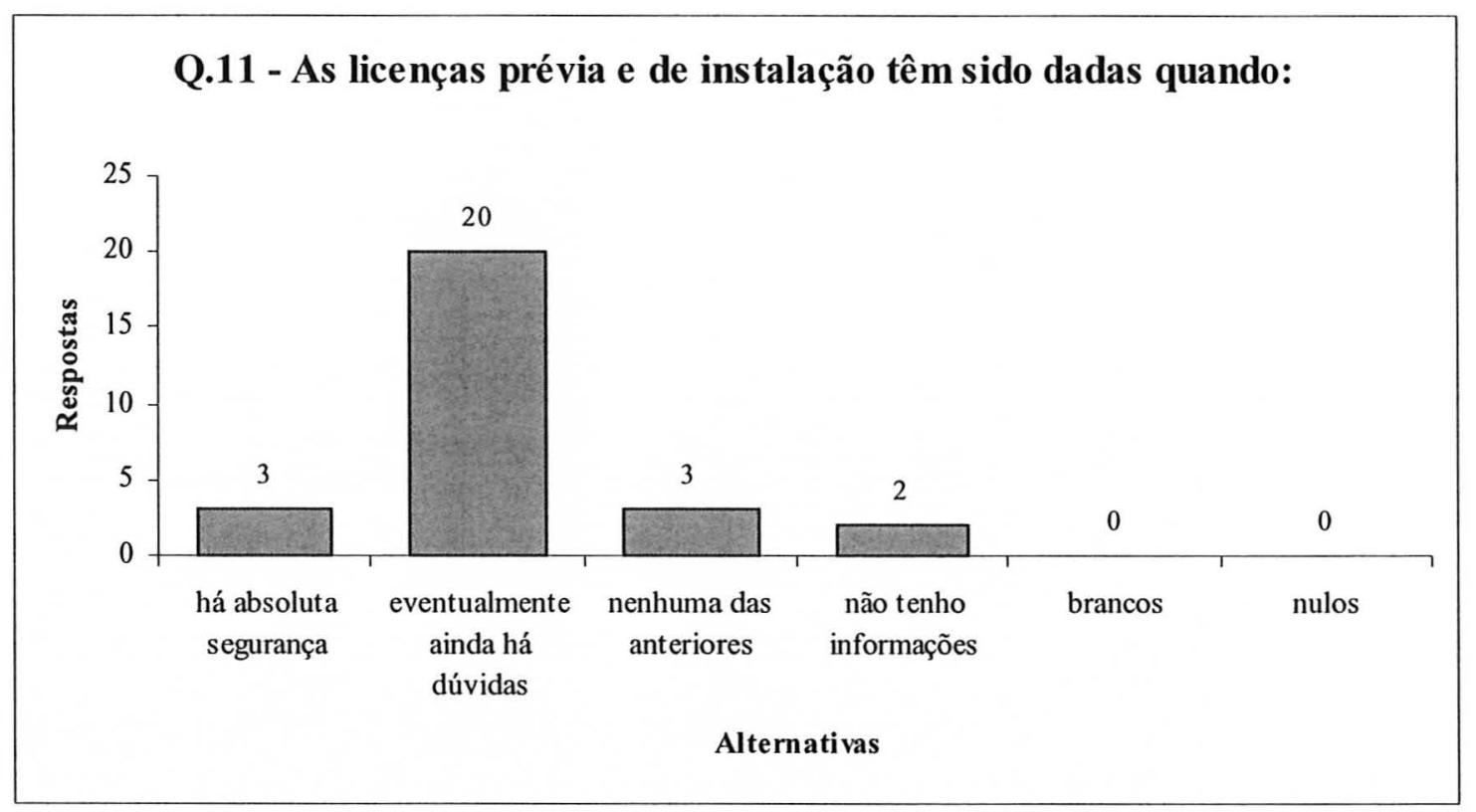

Figura 26 - Emissões das licenças ambientais 


\subsubsection{Coordenação e formação de equipes multidisciplinares nos EIA}

Segundo Moreira (1993), o que mais afeta os estudos são os problemas de coordenação técnica. As empresas de consultoria tendem a tratar a organização dos estudos de impacto ambiental como tratam os trabalhos com que estão mais familiarizadas. O coordenador limita-se a distribuir e cobrar as tarefas, controlar os gastos e os cronogramas e fornecer apoio aos profissionais das diferentes disciplinas, deixando a desejar a integração dos aspectos setoriais do meio ambiente, quase sempre interdependentes.

Ainda de acordo com o autor, os produtos são relatórios formados de estudos setoriais justapostos que não conseguem representar as prováveis alterações a serem produzidas nos sistemas ambientais pela realização do projeto. As equipes encarregadas de um estudo de impacto ambiental, além de multidisciplinar, precisam de coordenação e métodos apropriados, para que possam desenvolver um processo de trabalho interdisciplinar, cujo resultado se aproxime do que provavelmente ocorrerá no meio ambiente, caso o projeto em questão seja implantado.

Uma questão de grande interesse é a que se refere à exigência do EIA ser realizado por equipe multidisciplinar habilitada, não dependente direta ou indiretamente do proponente do projeto, e que será responsável tecnicamente pelos resultados apresentados. É a exigência exarada no artigo $7^{\circ}$, da Resolução Conama n.001/86. Urge consignar, igualmente, o que o artigo $8^{\circ}$ da mesma resolução determina que "correrão por conta do proponente do projeto todas as despesas e os custos referentes à realização do estudo de impacto ambiental, tais como: coleta e aquisição dos dados e informações, trabalhos e inspeções de campo, análises de laboratório, estudos técnicos e científicos e acompanhamento e monitoramento dos impactos, elaboração do Rima e fornecimento de pelo menos cinco cópias".

Comparando-se as disposições supramencionadas, verifica-se o problema da elaboração do EIA/Rima, no que diz respeito à equipe técnica que o elabora não depender direta ou indiretamente do proponente do projeto. De fato, como será possível que todas as despesas e os custos referentes à realização do EIA/RIMA fiquem por conta do proponente, sem que com ele haja uma relação de dependência da equipe técnica que 
o elaborará? O proponente deverá escolher a equipe técnica mediante contratação com empresas ou com técnicos especializados. De qualquer forma, haverá sempre uma relação de dependência econômica e jurídica do proponente com os profissionais que deverão elaborar o EIA/RIMA.

Para os especialistas consultados, $42,86 \%$ afirmam que a coordenação e a formação das equipes multidisciplinares nos EIA tem sido normalmente fracas na organização dos diagnósticos; enquanto que $32,14 \%$ dizem o contrário; entretanto $17,86 \%$ não tem informações quanto ao tema (Figura 27).

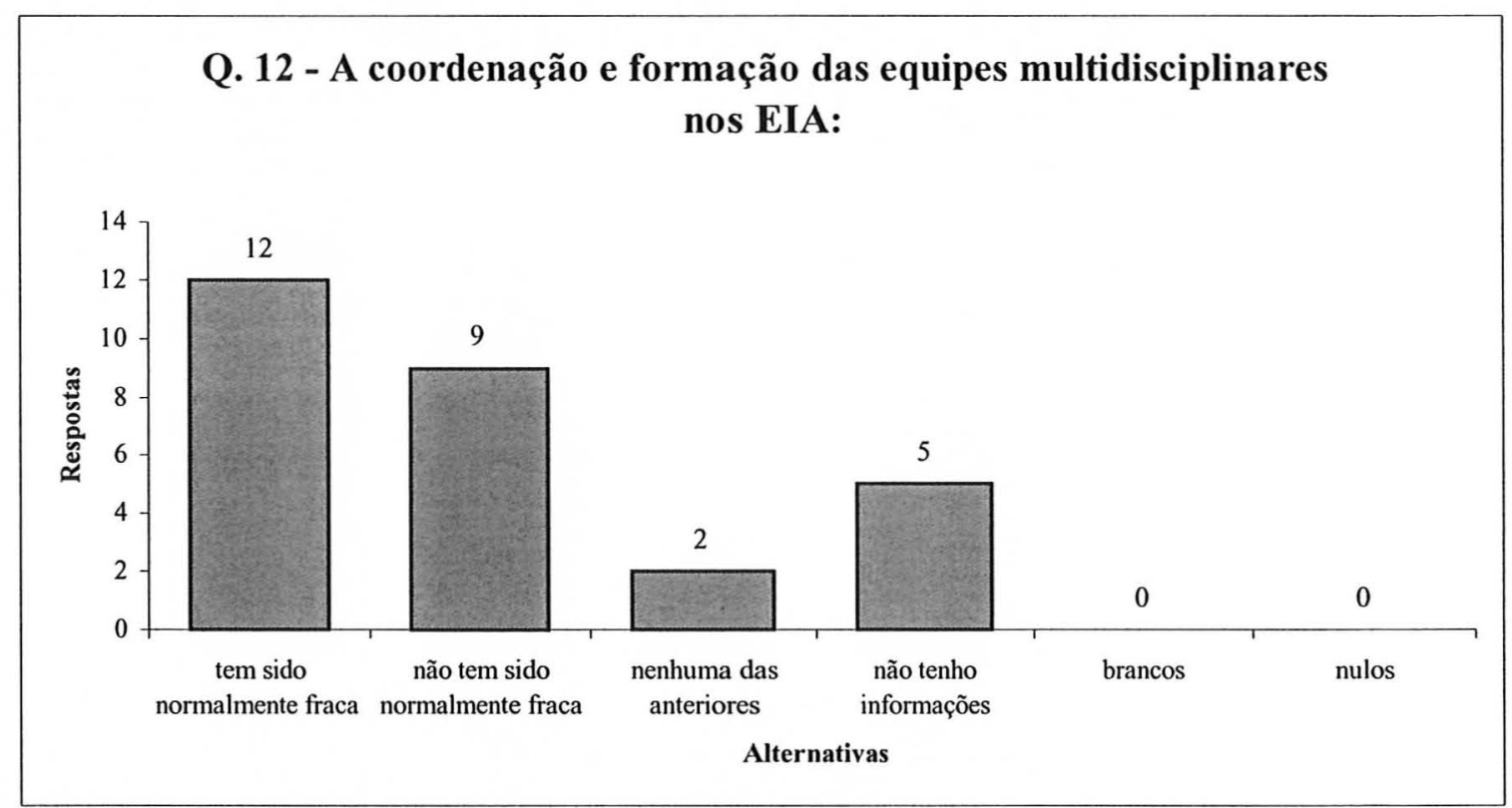

Figura 27 - A coordenação de equipes multidisciplinares

\subsubsection{Banco de dados nos órgãos ambientais e as empresas consultoras}

De acordo com os especialistas consultados, $50,00 \%$, afirmam que os bancos de dados não tem sido implantados nos Estados, enquanto que 17,86\% dizem o contrário; entretanto $25 \%$ não tem informações quanto ao assunto (Figura 28).

A questão da carência de dados e informações que sirvam de base aos estudos de impacto ambiental, diz respeito, em parte, à falta de estrutura e recursos dos órgãos ambientais na medida em que lhes cabe a monitoração de qualidade do meio ambiente, ao menos para os fatores tradicionalmente ligados às suas áreas específicas de controle: 
o ar, a água, e os ecossistemas naturais. São poucos os Estados que mantêm programas de monitoração ou qualquer outra forma de acompanhamento das condições do meio ambiente, ainda assim concentrados nas áreas e nos sistemas mais críticos e degradados.

O Sistema Nacional de Informações Ambientais (SISNIMA), embora previsto na Lei de Política Nacional de Meio Ambiente desde 1981, não começou a ser implantado nos órgãos ambientais. As pesquisas acadêmicas e as coletas de dados realizadas como parte dos estudos de impacto ambiental não têm sido apropriadas no sentido de alimentar ou dar início a um banco de dados ambientais. Também neste caso são poucos os recursos e a sensibilidade dos governantes, restando aos órgãos de meio ambiente esperar por apoio externo para a compra de equipamentos e montagem de laboratórios, programas, monitoração e sistemas de informações. Alguns dados sobre elementos físicos e componentes socioeconômicos do meio ambiente, embora existam em outras instituições, mais ou menos atualizadas, são coletados com propósitos diversos, os que traz dificuldades de consistência e adequação aos estudos ambientais.

Em geral os cronogramas e orçamentos restritos dos empreendedores impedem a coleta de dados primários que poderiam suprir as deficiências de informação das entidades de meio ambiente e demais instituições do governo.

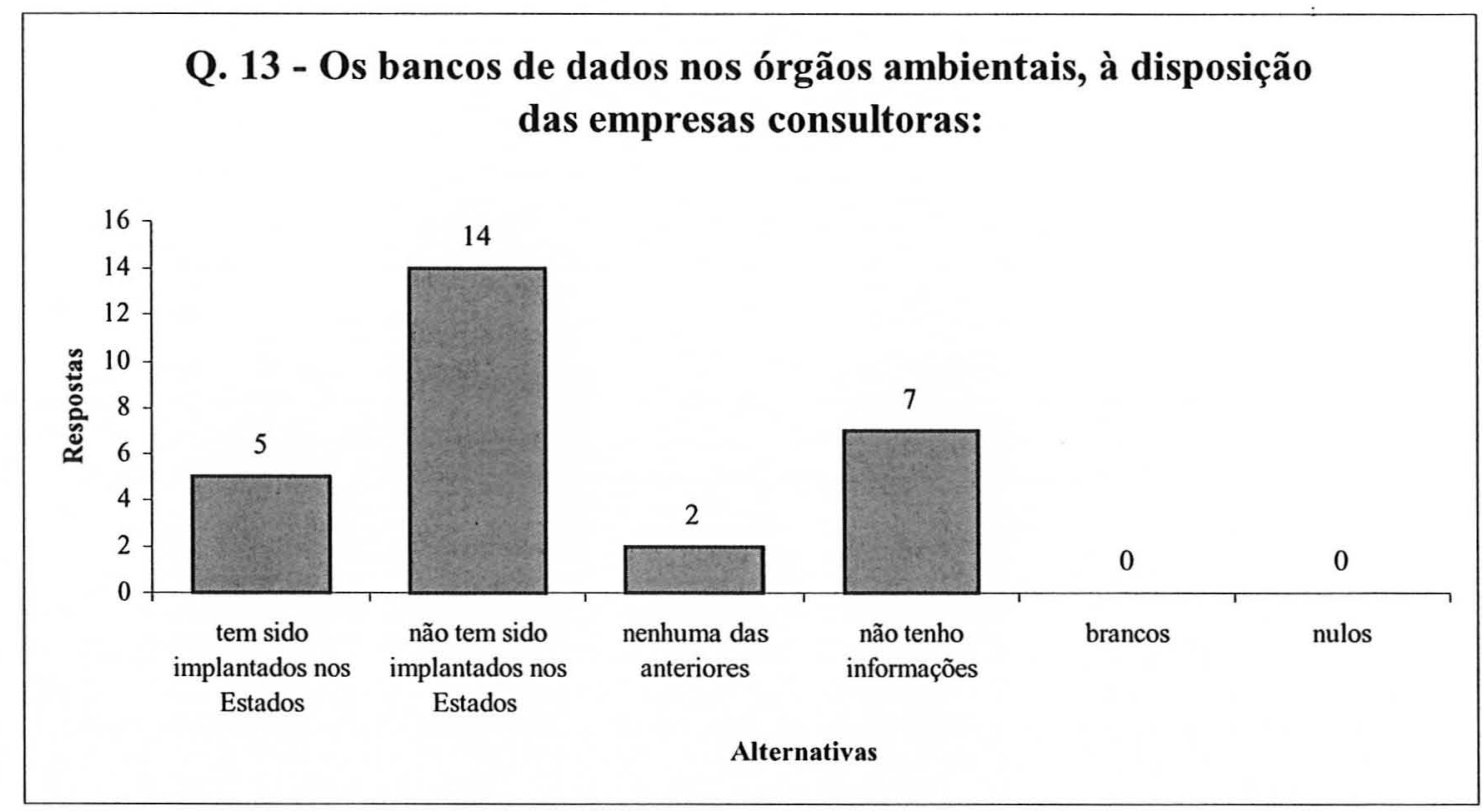

Figura 28 - Os bancos de dados nos órgãos ambientais 


\subsubsection{A Remuneração salarial nos órgãos ambientais}

De acordo com os especialistas consultados, $64,29 \%$ acreditam que não existe uma política salarial, enquanto que nenhum respondeu afirmativamente. Entretanto, 32,14\% não tem informações sobre o assunto (Figura 29).

A falta de uma política salarial nos órgãos ambientais tem contribuído para uma grande evasão de técnicos que se direcionam para iniciativa privada, isto é o Estado tem servido como um agente de capacitação de profissionais para empresas privadas. O Estado não têm como manter uma equipe técnica primeiro, pela falta de recursos, segundo, porque pagam mal seus técnicos e finalmente porque não têm a preocupação de criação e manutenção de uma equipe.

Normalmente, a cada mudança no governo estadual, troca-se à cúpula, os técnicos treinados nessa área vão passar a tratar de outras atividades, e com isso se perde a capacitação que foi feita. Pode-se concluir que existe um problema muito sério de capacitação técnica dos órgãos, estaduais e enquanto esta situação continuar, vai ser muito dificil que alguma coisa realmente significativa se faça nos Órgãos Ambientais sem plano de carreira para seus Técnicos.

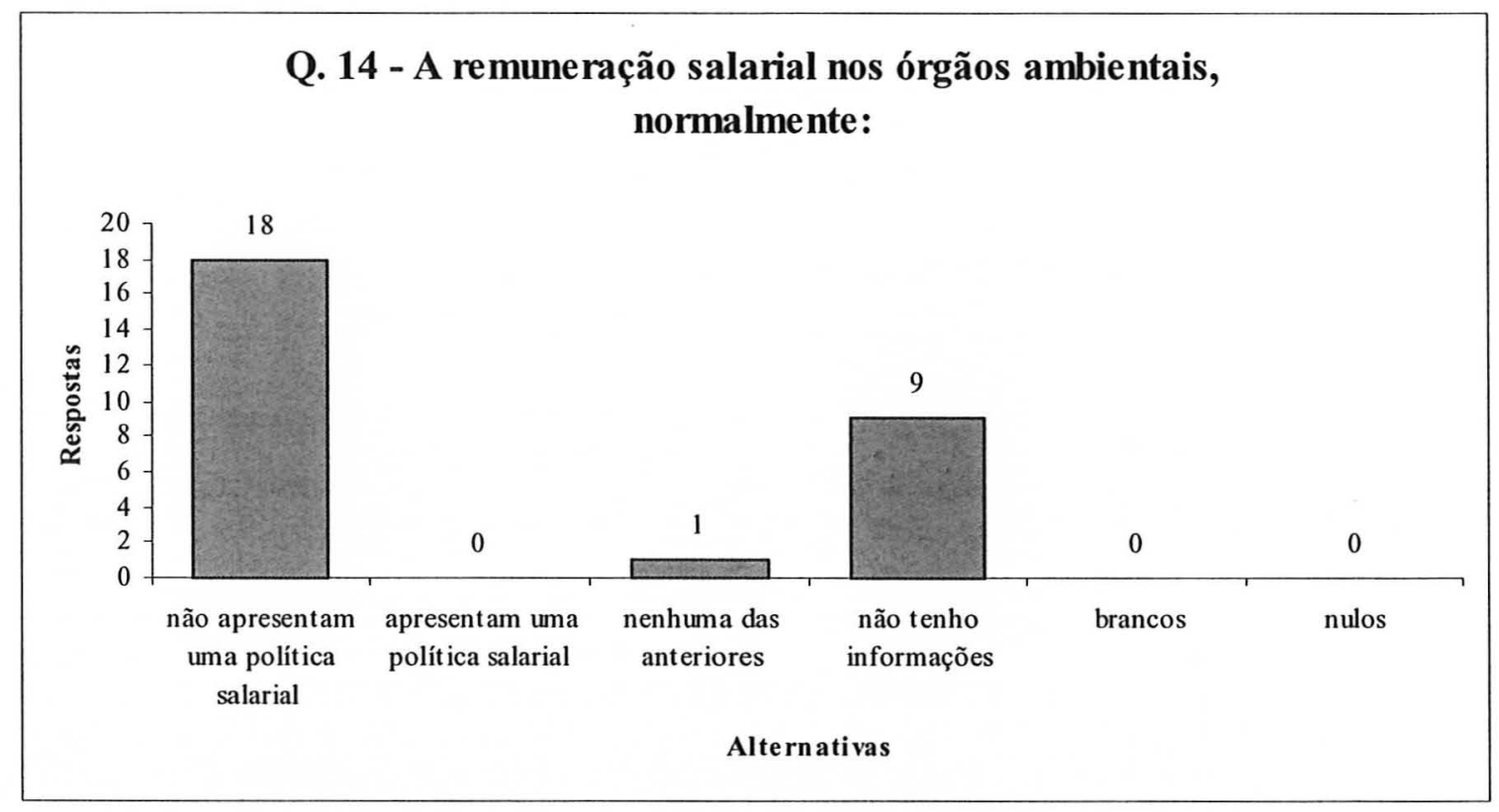

Figura 29 - A remuneração salarial nos órgãos ambientais 


\subsubsection{5 Órgãos ambientais e a contratação de consultoria ambiental externa}

De acordo com os especialistas consultados, $17,86 \%$ afirmam que as esporádicas contratações de consultoria ambiental têm contribuído para emissões das licenças ambientais; enquanto que $14,29 \%$ dizem o contrário. Entretanto $32,14 \%$ responderam nenhuma das anteriores; enquanto que $35,71 \%$ não tem informações a respeito do assunto, conforme mostra na (Figura 30).

As contratações de consultorias externas têm sido muito pequenas nos órgãos ambientais, e provavelmente em decorrência da falta de recursos financeiros. Isto fato com certeza iriam agilizar o processo de licenciamento ambiental.

-Nos EIA/RIMA considerados complexos, deveria ser fixada, através de legislação complementar, uma verba de 0,1 a $0,2 \%$ para contratação de consultoria externa através dos órgãos ambientais.

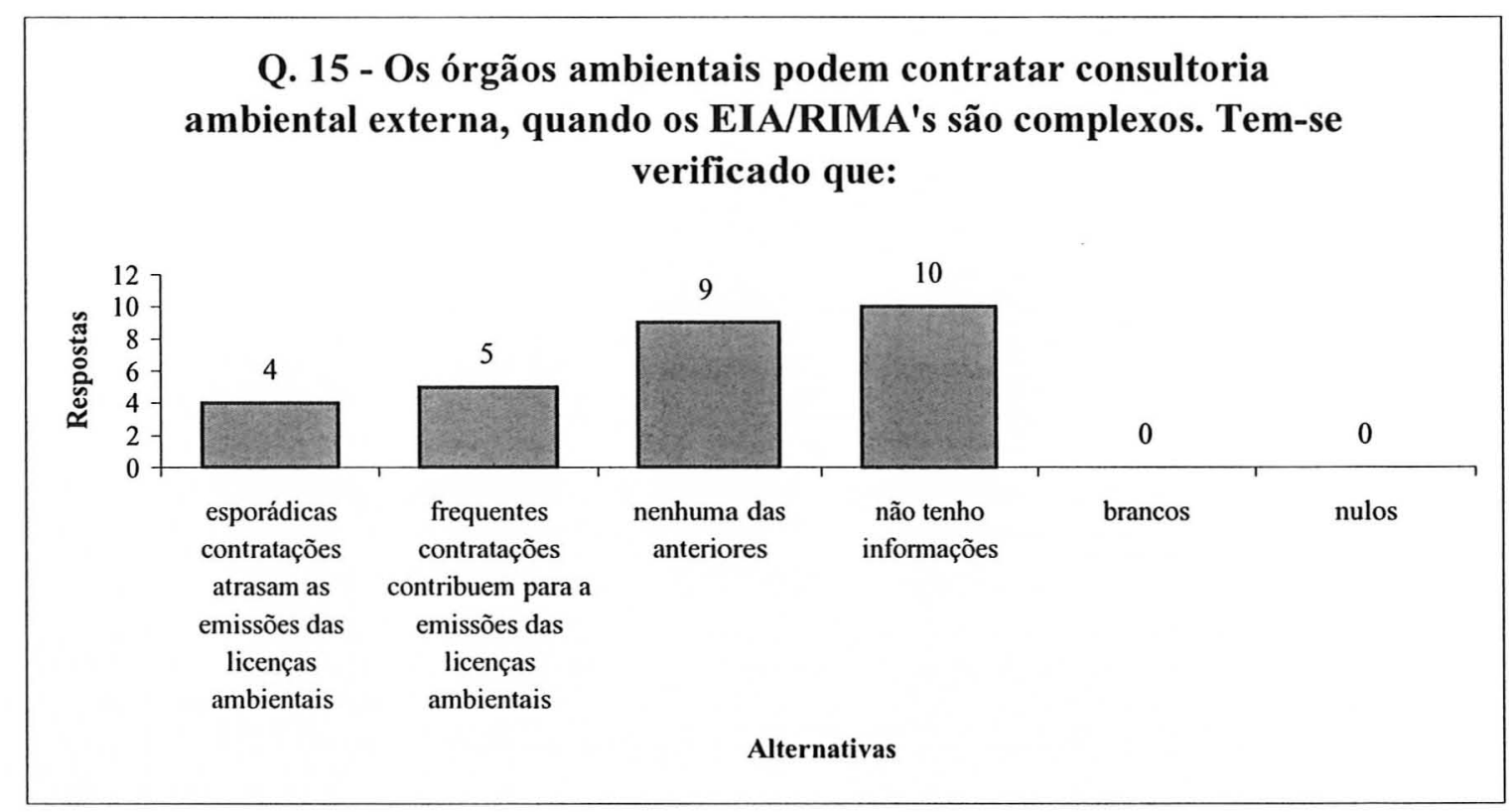

Figura 30 - A contratação de consultoria ambiental externa para elaboração de EIA/RIMA 


\subsubsection{Os relacionamentos entre empreendedores, órgãos ambientais e ONG's, quanto à gestão de EIA/RIMA}

De acordo com os especialistas consultados, $67,86 \%$ afirmam que o relacionamento entre os vários agentes envolvidos tem sido conflituoso, mas mostrando evolução nas relações de parceria, enquanto que 3,57\% dizem o contrário; entretanto 17,86\% responderam nenhuma das anteriores (Figura 31).

Os órgãos ambientais na condição de licenciador, têm o papel principal de promover articulação entre os diversos agentes sociais envolvidos no processo de Avaliação de Impacto Ambiental, cabendo-lhe a maior parcela de responsabilidade no alcance da efetividade da participação social ao longo de todo o processo.

Esse papel exige a capacidade de administrar conflitos de interesse, que pode ser viabilizada através do emprego de diferentes mecanismos formais de participação, em cada fase do processo de AIA.

O empreendedor deve estabelecer uma relação de parceria com o órgão ambiental, onde os antagonismos sejam tratados com o objetivo de se alcançarem soluções compartilhadas.

Enquanto representantes da diversidade de interesses presentes na sociedade, essas entidades devem, além de questionar, compartilhar das decisões de prevenção, controle, mitigação e monitoramento dos efeitos ambientais esperados e fiscalizar a execução dos programas de controle ambiental acordados com o empreendedor. Estas relações sempre têm sido conflituosa, mas existem indicativos que está ocorrendo uma mudança nos relacionamentos entre os segmentos, na busca de melhor entendimento. 


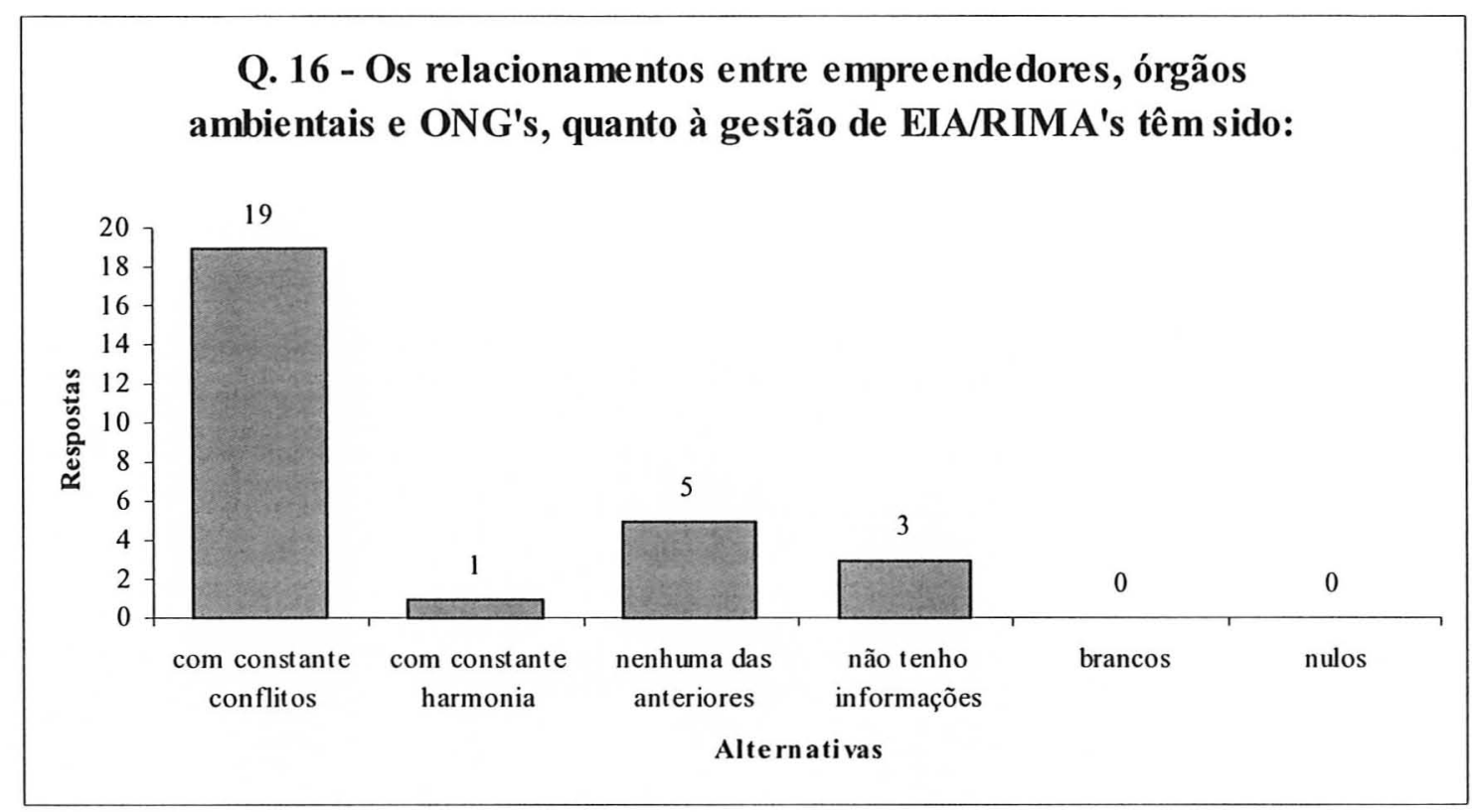

Figura 31 - Os relacionamentos entre os agentes envolvidos

\subsubsection{As possíveis carências técnicas de empresas habilitadas}

Uma questão importante é carência de empresas habilitadas para elaboração EIA/RIMA, apesar de existirem várias empresas de consultoria ambiental que possuem equipes de alto nível técnico-científico, realizando trabalhos efetivamente bons.

Isso não significa, porém, que muito não se tenha de desenvolver quanto ao treinamento, à formação de pessoal efetivamente qualificado para compor equipes multidisciplinares.

De acordo com os especialistas consultados, 75,00\% afirmam que ocorrem fragilidades nos EIA/RIMA apresentados junto aos órgãos ambientais; enquanto que nenhum respondeu afirmativamente. Entretanto, 14,29\% responderam nenhuma das anteriores, conforme se apresenta na (Figura 32). 


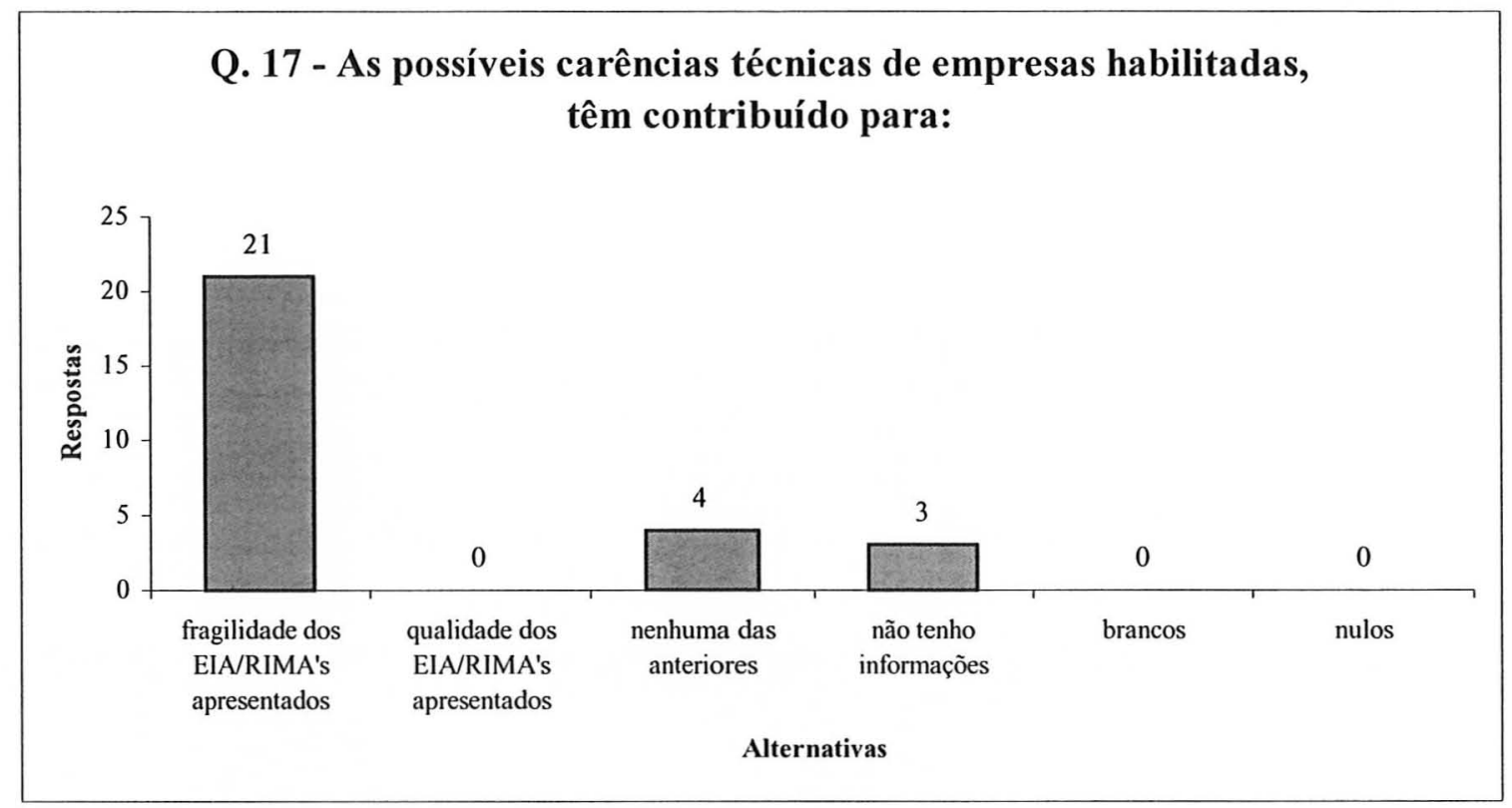

Figura 32 - A carências de empresas de consultoria ambiental

\subsubsection{Divulgação e acesso às informações dos Estudos de Impacto Ambiental concluídos}

Uma dificuldade freqüentemente observada no Brasil é o acesso a relatórios e outros tipos de informações existentes em empresas estatais, firmas de consultoria, de engenharia, etc. Há muitas informações úteis, de boa qualidade naquelas entidades mas não há um catálogo, não há acesso às mesmas. Outras fontes importantes de informações são as dissertações e teses das universidades, muitas não publicadas. Ainda que haja catálogos de teses, não há, por vezes, uma boa divulgação de seus conteúdos. Deveria ser implantado no País, um sistema mais ágil de acesso às informações ambientais disponíveis em todas as entidades, tanto particulares como governamentais (Tomassi, 1993).

A falta de divulgação dos relatórios de EIA é um aspecto grave do nosso sistema. Os EIA são distribuídos no Pará apenas à biblioteca do órgão ambiental, servindo apenas para consultas, não sendo permitido, a reprodução e empréstimos; deveriam ser de fácil acesso e muito bem divulgados, por exemplo, pelos jornais. As decisões finais devem ser divulgadas rotineiramente em Diário Oficial; por exemplo, no Estado de São Paulo, 
já se faz à divulgação do resultado do parecer técnico. No Estado do Pará, são apenas publicadas as concessões aos empreendedores; deveriam também fazer uma ampla divulgação, em revistas científicas. Aliás, os órgãos de controle ambiental deveriam ter publicações que periodicamente divulgassem os projetos analisados, novas legislações etc.

Outra questão importante, é que não pode haver segredo num EIA; todas informações necessárias devem ser incluídas. Ainda que devam ser preservados as patentes e os direitos sobre processos tecnológicos industriais etc, nunca poderão ser sonegadas informações pelo proponente que permitam conhecer, por exemplo, suas fontes de emissão de poluentes (Tomasi, 1993).

Umas das dificuldades que observamos, para uma ampla utilização de EIA no Brasil, são as grandes diferenças técnico-científicas, políticas e econômicas que ainda persistem entre os diferentes Estados.

De acordo com os especialistas consultados, 67,86\% afirmam que não ocorrem divulgações a contento por parte dos órgãos ambientais sobre EIA/RIMA; enquanto que $14,29 \%$ dizem o contrário; no entanto 3,57\% responderam nenhuma das anteriores; e 14,29\%, não tem informações a esse respeito (Figura 33).

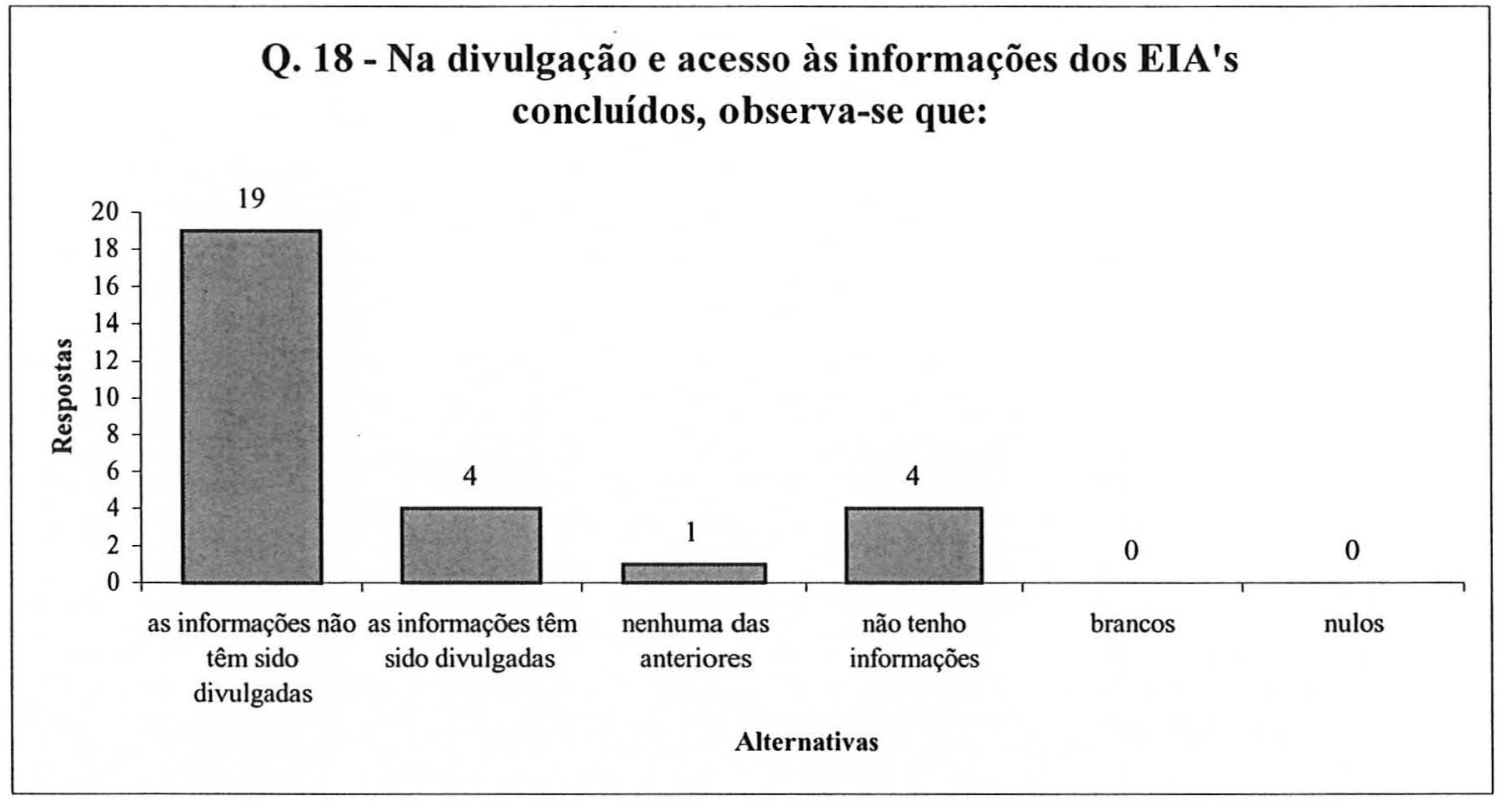

Figura 33 - Divulgação das informações sobre EIA/RIMA 


\subsubsection{Os programas de controle ambiental}

De acordo com os especialistas consultados, $50,00 \%$ afirmam que os programas de controle ambiental apresentam-se incompletos e não oferecem segurança para a implantação definitiva dos empreendimentos; enquanto que 10,71\% dizem o contrário; e $25,00 \%$ responderam nenhuma das anteriores; $14,29 \%$, não possui informações quanto ao assunto (Figura 34).

Esse retrato do resultado da pesquisa vai ao encontro da análise crítica feita dos PCA da MSS na área socioeconômica, embora apresentem avanços conceituais nas suas proposições práticas, parecem reproduzir o mesmo viés dos projetos que os antecederam na Amazônia. No caso da MSS, a responsabilidade da empresa é importante na medida em que a jazida a ser explotada apresenta vida útil de apenas 15 anos, tempo muito limitado para produzir mudanças socioeconômicas benéficas que sejam significativas numa região pobre e extremamente carente de investimentos produtivos sociais para proporcionar um melhor nível de bem-estar tanto às gerações atuais às futuras. Deve ser um empreendimento que, de fato, incorpore os conceitos de Desenvolvimento Sustentável.

Analisando-se os Planos de Controle Ambiental na área socioeconômica pode-se concluir que apresentam falhas, faltando importantes definições técnicas e detalhamentos indispensáveis para um empreendimento minerário de tal amplitude.

Nos demais programas, muito do que foi apresentado pode ser aproveitado em um amplo Plano de Gestão Ambiental para a região em questão, apoiado em um efetivo e bem delineado Sistema de Gestão Ambiental para a Mineração Serra do Sossego.

As varias imperfeições presentes no EIA, no RIMA e nas complementações poderiam ser corrigidas no Parecer da SECTAM. Este documento é um registro das análises efetuadas pela equipe técnica da SECTAM e de suas conclusões. Contém uma síntese dados fornecidos pelo proponente (nos vários documentos técnicos), o que inclui a caracterização do projeto, os impactos ambientais previstos e as medidas mitigadoras, de monitoramento e de recuperação propostas. Além disso, o parecer apresenta informações obtidas em vistorias, e do EIA/RIMA, onde novas medidas são 
apresentadas como condicionantes à aprovação do projeto e emite um juízo de valor acerca da viabilidade ambiental do empreendimento.

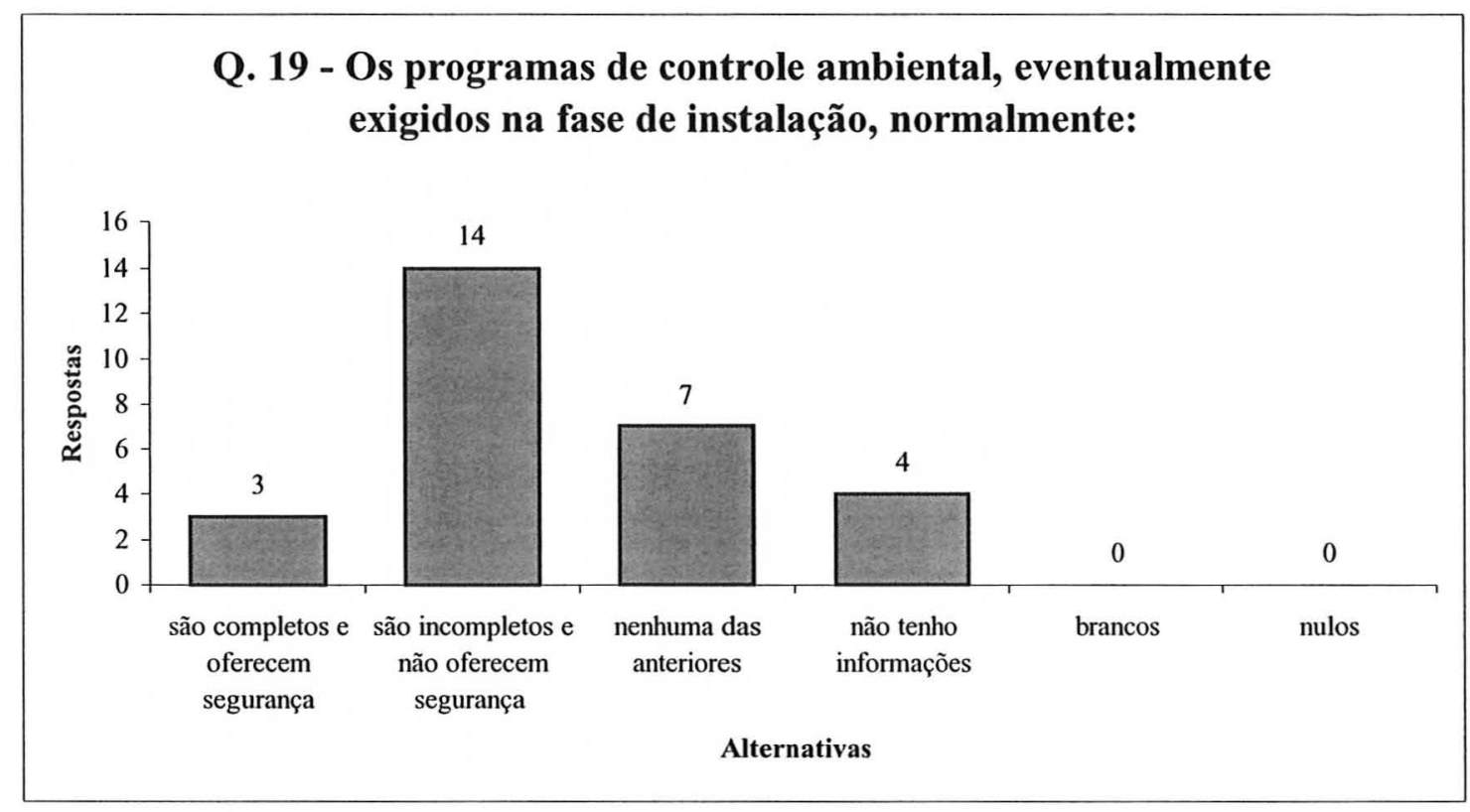

Figura 34 - Os programas de controle ambiental

\subsubsection{A Resolução 001/86 quanto à elaboração dos EIA/RIMA}

Após a promulgação da legislação da Política Nacional do Meio Ambiental, a Lei 6.938/81, foi aprovada a Resolução 001/86 que, na mesma linha, estabeleceu as condições de elaboração e apresentação do EIA/RIMA, como requisito para o licenciamento ambiental de determinadas obras ou atividades.

Segundo Gouvêa (1993), de certa forma esta Resolução veio reforçar a ligação da avaliação de impactos ambientais à figura do licenciamento e aí foi ocorrendo, certamente, uma inversão de valores. A licença ambiental, que foi criada como um instrumento extremamente importante, como um mecanismo de atuação dos órgãos ambientais para controle prévio da instalação de algumas atividades efetiva ou potencialmente poluidoras ou degradadoras, e para exigências de sistemas de controle e minimização dos efeitos deletérios dessas atividades, começou a ser vista, por alguns, quase que como uma atividade meramente burocráticas, uma "chancela mecânica", 
conforme se observa nos comentários feitos por alguns técnicos e juristas com relação à exigência ou não de EIA/RIMA em determinados casos.

Isso vem provocando uma série de discussões sobre os casos de exigência ou não de EIA/RIMA e, em especial, sobre a interpretação do disposto no artigo $2^{\circ}$ da Resolução CONAMA no 01/86 que contém um elenco de atividades que, em tese, dependem da aprovação do EIA/RIMA para obter o licenciamento ambiental. E essas discussões existem justamente porque alguns juristas, como é caso do Prof. Paulo Affonso Leme Machado, entendem que todas as atividades ali relacionadas dependem do EIA/RIMA, independentemente de porte, localização, características, do conhecimento que o Poder Público já disponha sobre o impacto possível da obra ou sobre região a ser afetada etc (Gouvêa, 1993).

A referida Resolução apresentou um elenco meramente exemplificativo das atividades que, presumidas de maior potencial ofensivo, estariam a demandar a realização de prévio estudo de impacto ambiental. É o que se depreende da expressão "tais como", que precede a enunciação do artigo $2^{\circ}$. Alguns juristas entendem que a expressão acima mencionada deixa uma evidência de listagem onde as decisões e definições ficam a critério do órgão aplicador.

De acordo com os especialistas consultados, 67,86\% afirmam que a Resolução 001/86 não tem sido plenamente eficaz e deveria ser reformulada, enquanto que $10,71 \%$ dizem o contrário (Figura 35).

Ainda de acordo com os consultados 39,29\% concordam em abreviar o processo de análise dos EIA/RIMA; enquanto que 25,00\% acreditam no contrário; e 25,00\% responderam nenhuma das anteriores (Figura 36). 


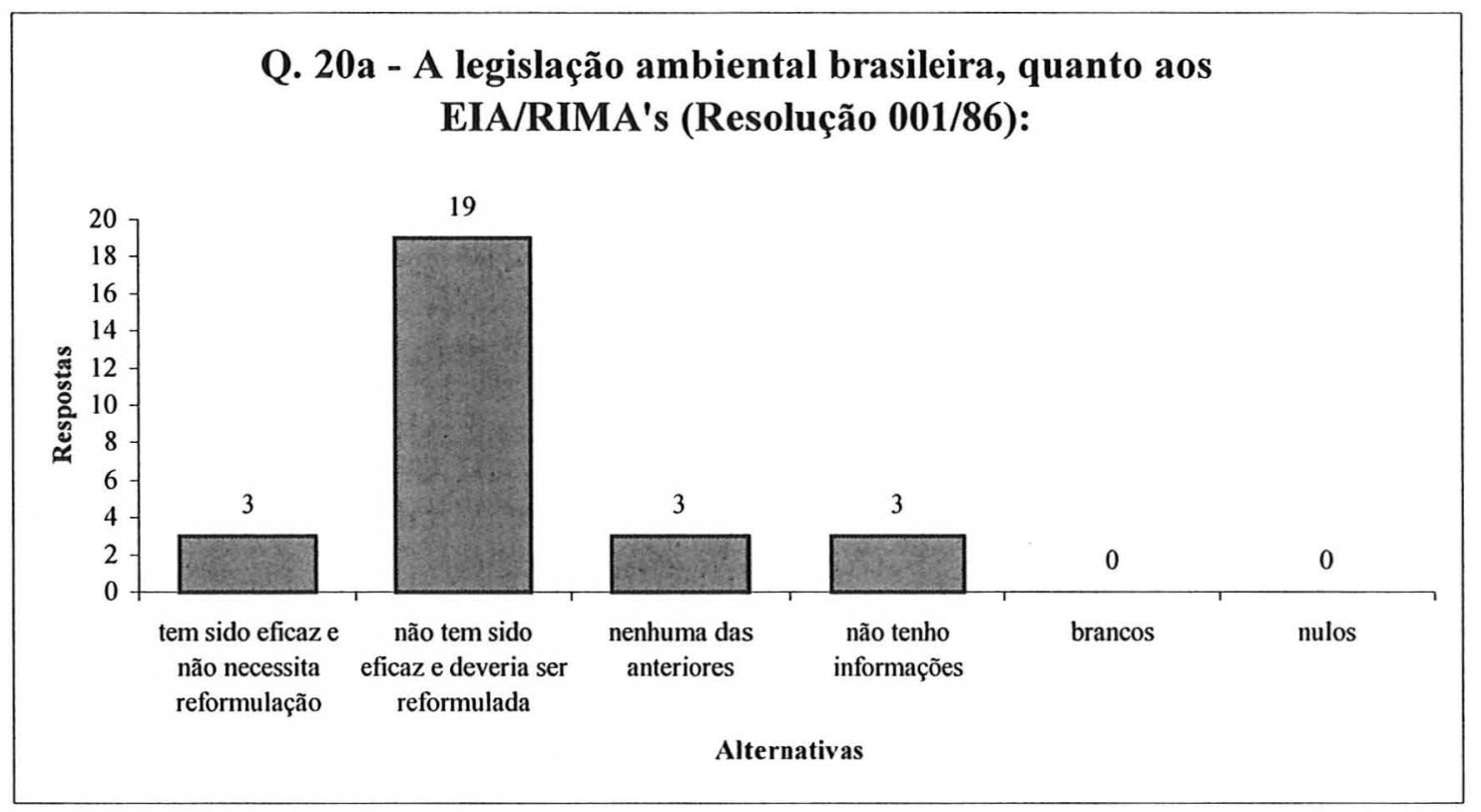

Figura 35 - A Resolução 001/86 referente a EIA/RIMA

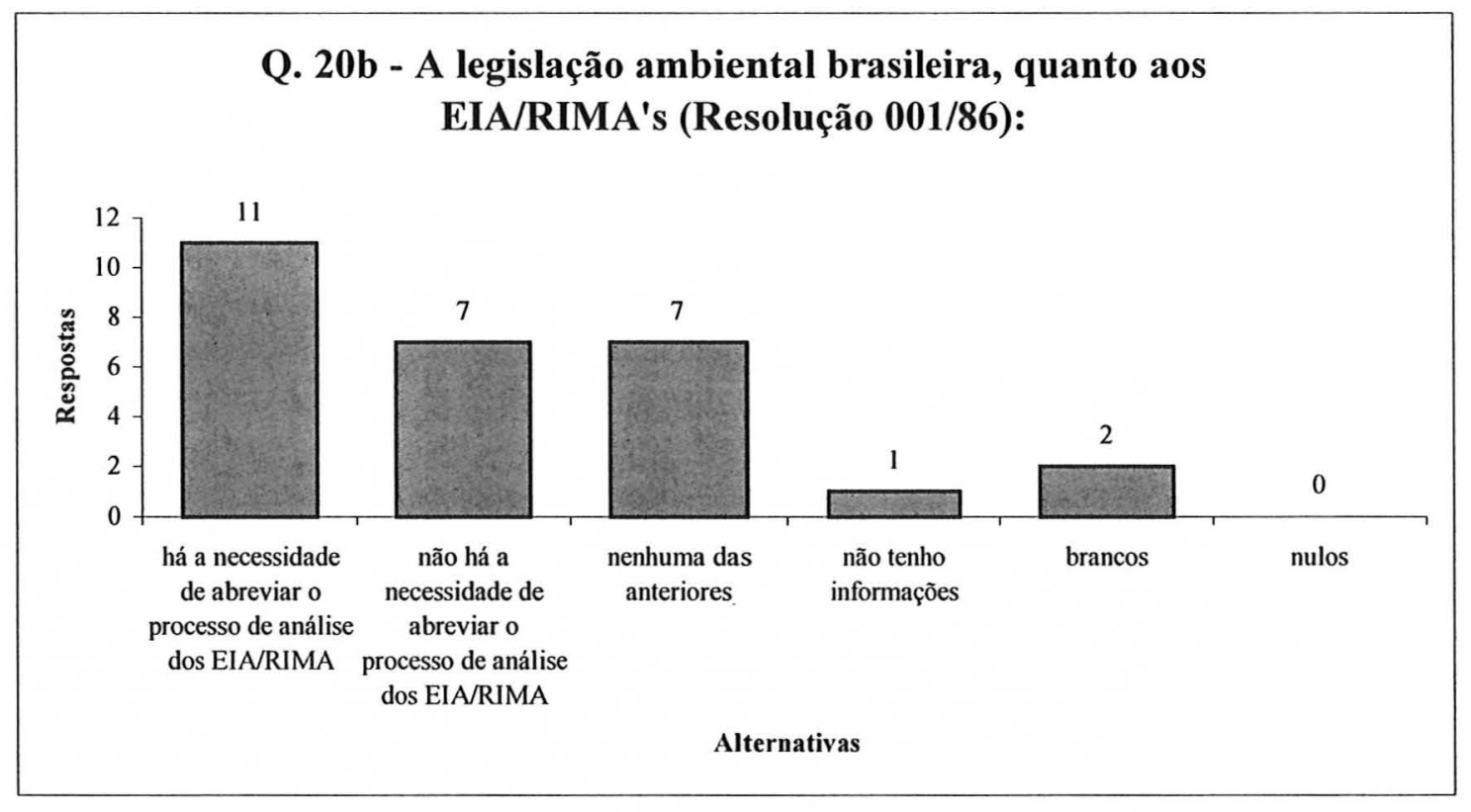

Figura 36 - A Resolução 001/86 referente ao EIA/RIMA 


\subsubsection{Os grandes interesses nos EIA/RIMAs de grandes projetos}

Este é ou reprovação dos grandes projetos. Em alguns EIA/RIMA ocorrem pressões políticas para acelerar o processo de licenciamento em outras para aprovar conforme apresenta o resultados da pesquisa, muitas vezes embora o documento não apresenta condições de ser aprovado; isto não só ocorre na Amazônia, como em todo o Brasil. De acordo com os especialistas isto vem afirmar, que existe o problema e que ele ocorre. assunto bem delicado, relaciona-se aos interesses que estão por traz da aprovação

De acordo com os especialistas consultados, $89,29 \%$ afirmam que normalmente são observadas pressões políticas para aprovação ou reprovação dos projetos; enquanto que nenhum respondeu negativamente (Figura 37).

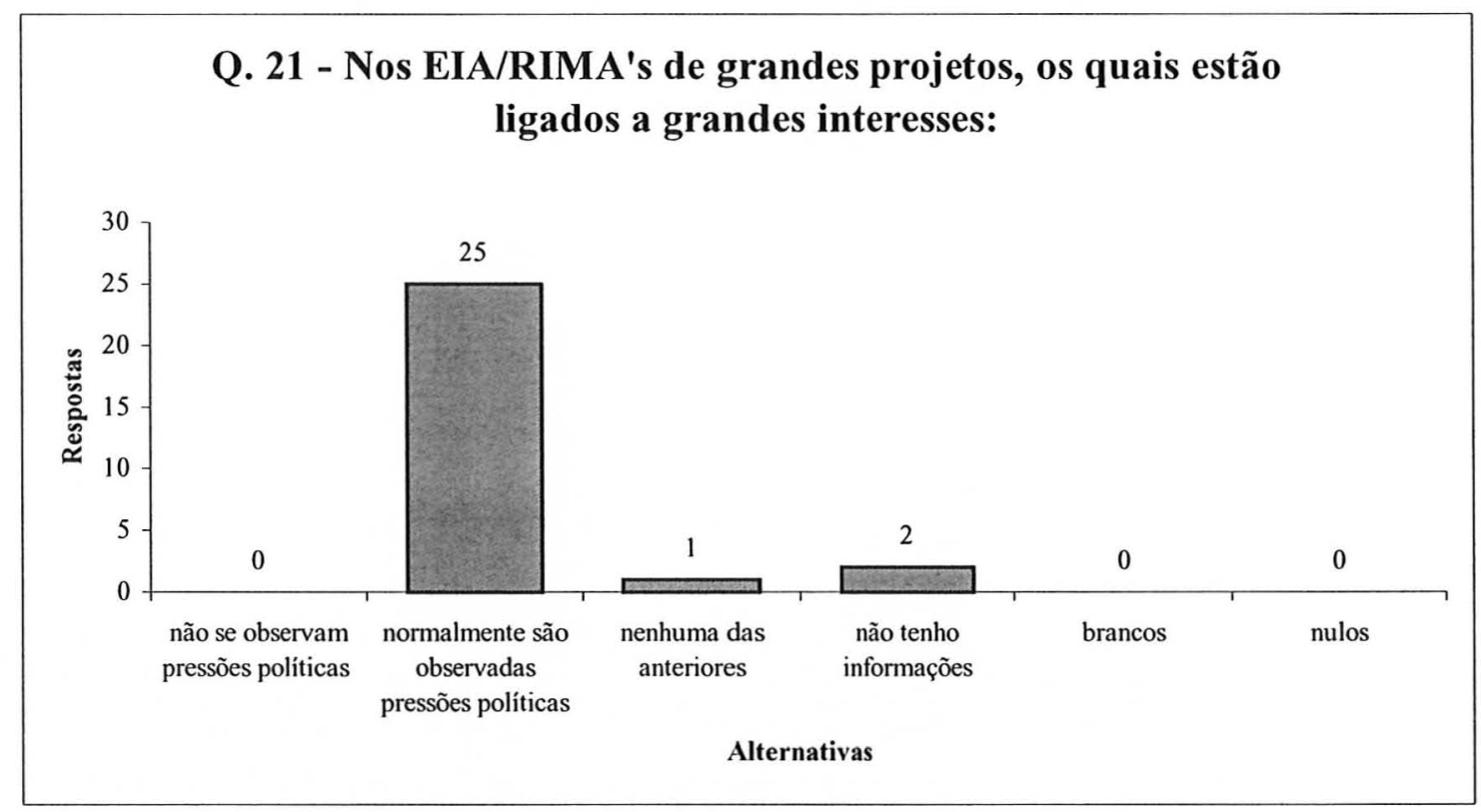

Figura 37 -Interesses ligados à grandes projetos

Finalmente a questão 22 foi abordada no questionário como uma questão aberta e como tal foi feito um agrupamento das respostas quer mais se assemelham, e evidenciaram os seguintes problemas.

1) A excessiva solicitação de informações complementares na fase de análise prévia e o evidente descompromisso após a emissão da Licença de Operação.

2) A ausência de avaliação estratégica nos EIA. 
3) A falta de compreensão dos dirigentes dos órgãos ambientais sobre os papéis, as potencialidades e as limitações da avaliação de impacto ambiental;

4) A reduzida capacitação técnica dos assistentes técnicos do Ministério Público, excessivas rotatividade de funcionários nos departamentos de avaliação de impacto ambiental dos órgãos ambientais.

5) A baixa remuneração dos técnicos dos órgãos ambientais, o que faz com que haja, uma alta rotatividade em seu quadro técnico, respondendo pela perda de profissionais experientes e mais qualificados para a iniciativa privada, sendo por este motivo normalmente constituído por pessoal com baixa qualificação técnica e pouca experiência, normalmente recém formados, além de que este fator poderá gerar problemas de corrup̧̧ão interna;

6) A falta do acompanhamento dos empreendimentos licenciados cuja avaliação dos relatórios de cumprimento das condicionantes só é feito quando da renovação da Licença em decorrência do número reduzido de técnicos, do curto prazo de validade das licenças, e da má gestão dos recursos financeiros arrecadados pelas instituições, que muito bem poderiam financiar as vistorias técnicas para acompanhamento da implantação dos empreendimentos.

7) A não consolidação das informações recebidas nos processos de licenciamentos, de forma a subsidiar a construção de cenários regionais, o que viabilizaria identificar claramente quais as informações necessárias para a inserção de um determinado empreendimento em uma dada região, de forma a subsidiar concretamente a tomada de decisão quanto ao licenciamento.

Vale ressaltar que, embora com problemas, os especialistas consideram a elaboração do EIA/RIMA ou outros estudos (conforme o estado e o tamanho do empreendimento) um avanço para o país. 


\section{CONCLUSÕES}

Os resultados do presente trabalho confirmam a hipótese estabelecida e permitem concluir que os EIA/RIMA, embora representem historicamente um avanço relevante nas questões ambientais no país, após 15 anos de efetiva aplicação, têm apresentado diversos problemas e imperfeições que estão comprometendo a AIA no Brasil, os quais são apresentados a seguir.

- Os Termos de Referência devem ser anexados aos EIA/RIMA, para que se possa averiguar claramente o que foi exigido pelos órgãos ambientais.

- Os custos para elaboração do EIA, devem ser informados à sociedade, com a finalidade de se fazer uma correlação entre o valor do empreendimento e grau de dificuldade do estudo.

- Os prazos para as execuções dos EIA/RIMA, normalmente são muito pequenos visando diminuir o tempo para o licenciamento ambiental, bem como a redução dos custos operacionais.

- Os grandes projetos necessitam normalmente de levantamentos nos períodos de inverno e verão, para que sejam consideradas as variações da sazonalidade, fato que normalmente não estão ocorrendo.

- Devem ser realizados estudos particularizados para as Unidades de Conservação e para as Reservas Indígenas, quando estas estão localizadas na área de influência do projeto. 
- Os espaços participativos devem ser ampliados para promover discussões e dar transparência no processo de AIA com a criação de audiências públicas intermediárias; os RIMA devem evitar os termos técnicos, constituindo-se efetivamente em um instrumento de comunicação com a comunidade.

- As compensações ambientais relativas à implantação de grandes projetos, devem ser aplicadas na elaboração e implementação de Planos de Manejo de Unidades de Conservação.

- Deve ocorrer uma rigorosa fiscalização por parte do Ministério Público na aplicação da compensação ambiental repassada aos órgãos ambientais.

- Os levantamentos socioeconômicos para os estudos de impactos ambientais, têm se apresentado freqüentemente como superficiais, sendo necessário que haja maiores exigências nos Termos de Referência.

- O acompanhamento da execução das medidas mitigadoras e dos programas de monitoramento não vem ocorrendo de forma adequada em função do reduzido número de técnicos e da falta de recursos financeiros; os valores arrecadados pelas emissões das licenças ambientais devem ser dimensionados para que sejam aplicados nestas fiscalizações.

- Ocorrem conflitos de competências entre o IBAMA e Órgãos Ambientais no licenciamento de projetos, principalmente, quanto aos repasses dos recursos das compensações ambientais.

- Há a necessidade de formação e capacitação de equipes multidisciplinares para a elaboração dos EIA/RIMA promovendo a perfeita integração entre os meios físico, biológico e socioeconômico. 
- A implantação de banco de dados nos Órgãos Ambientais é fundamental para que se possam reduzir os custos e facilitar todas as etapas da AIA.

- As remunerações salariais dos Técnicos dos Órgãos Ambientais são geralmente baixas, provocando enorme rotatividade em alguns deles; são raras as ações de capacitação técnica.

- A contratação de equipes externas de consultoria para colaborar nas avaliações dos EIA/RIMA, pode contribuir para acelerar os processos de licenciamento ambiental e para o aperfeiçoamento do instrumento de AIA.

- É importante estreitar os relacionamentos entre os empreendedores, Órgãos Ambientais e as entidades de meio ambiente, para aprimorar as parcerias.

- A ocorrência de diversas empresas não habilitadas na elaboração dos EIA/RIMA tem resultado em estudos deficientes e reprovações de empreendimentos.

- Há a necessidade de capacitação dos profissionais da IV Câmara Técnica do Ministério Público, bem como maior integração destes Técnicos com os Órgãos Ambientais estaduais. 


\section{RECOMENDAÇÕES}

Com bases nos resultados do trabalho recomenda-se o que se segue.

- A inclusão do termo de referência como anexo do EIA/RIMA, o qual deve ser mais específico, e voltado para as necessidades dos estudos ambientais.

- Através de uma legislação complementar seja fixado um percentual (de 0,1 a $0,2 \%$ do valor do empreendimento) para a contratação de consultoria externa pelos Órgãos Ambientais para os EIA/RIMA considerados complexos.

- A implantação do Sistema Nacional de Informações Ambientais nos Estados com os bancos de dados atendendo a legislação em vigor, para a redução dos custos aos empreendedores e, sobretudo, para a implementação de um substancial Programa de Capacitação de Recursos Humanos.

- Que o Estado do Pará publique no Diário Oficial os pareceres técnicos a exemplo do que se faz no Estado de São Paulo.

- Que sejam ampliados os investimentos das empresas consultoras nos estudos do meio socioeconômico, principalmente na Amazônia.

- Que os recursos arrecadados com o pagamento das taxas das licenças sejam investidos na capacitação técnica dos funcionários dos órgãos ambientais, no acompanhamento da 
execução das medidas mitigadoras, e compensatórias para que o processo de licenciamento não se encerre com a emissão das licenças.

- Seria importante a realização de audiências públicas intermediárias antes da conclusão dos estudos ambientais, visando ampliar os espaços participativos para promover discussões e dar maior transparência ao processo de AIA.

- Seria indispensável uma análise mais rigorosa por parte dos Órgãos Ambientais, referente à sazonalidade nos grandes projetos.

- O RIMA deve ser elaborado em linguagem popular e desenvolver mecanismos de comunicação entre o proponente do projeto e os cidadãos, para identificar as preocupações e valores das comunidades em relação ao empreendimento.

- Seria recomendável uma fiscalização mais rigorosa por parte do Ministério Público na aplicação do percentual de compensação ambiental que é repassado aos órgãos ambientais. 


\title{
REFERÊNCIAS BIBLIOGRÁFICAS
}

\author{
ABSY, M.; ASSUNÇÃO, F.; FARIA, S.C. (Coord.) Avaliação de Impacto Ambiental: \\ agentes sociais, procedimentos e ferramentas. 1995. Instituto Brasileiro do Meio \\ Ambiente e dos Recursos Naturais Renováveis, Brasília, cap.3, p.134.
}

AB’ SABER, A.N.; MÜlLER-PLANTENBERG, C. Previsão de Impactos. São Paulo: EDUSP, 1994. 569p.

AUTY, R. M., WARHURST, A . Sustainable Developments in Mineral - Exporting Economies. Resour. n. 19, p.14-29, 1993.

BECKER, H.S. Métodos de pesquisa em ciências sociais. 2.ed. São Paulo: Hucitec, 1994. 178p.

BIOMÉTRICA. Parecer sobre o Plano de Controle Ambiental. Piracicaba - São Paulo, 2000, 50p. (Parecer técnico apresentado à Mineração Serra do Sossego).

BISSET, R. Introduction to EIA Methodes. WORKSHOP ON ENVIRONMENTAL MANAGEMENT AND ENVIRONMENTAL IMPACT ASSESSMENT, Kuwait, Proceedings:. Cocal. Editora, 1985. p.14-24. 
BRITO N.J.G. ELISABETH. Análise ambiental: estratégias e ações: Estudo de Impacto Ambiental (EIA) e Relatório de Impacto Ambiental (RIMA): erros e acertos. (Org.) Sâmia Tornisielo.S.M; José de Àvila Aguiar Coimbra- São Paulo: T. A. Queiroz/ Fundação Salim Farah Maluf; Rio Claro, São Paulo: Centro de Estudos Ambientais - UNESP, 1995, p.255-279.

BRASIL. Leis, decretos. Lei nº 6.938, de 31 de agosto de 1981. Dispõe sobre a Política Nacional do Meio Ambiente, seus fins e mecanismos de formulação e aplicação, Biblioteca do Senado Federal.

BRASIL, Conama - Conselho Nacional do Meio Ambiente. Resolução n. ${ }^{\circ} 009$. Brasília, 1987.

BRASIL, Conama - Conselho Nacional do Meio Ambiente. Resolução n. ${ }^{\circ} 010$. Brasília, 1987.

BRASIL, Conama - Conselho Nacional do Meio Ambiente. Resolução n. ${ }^{\circ}$ 001. Brasília, 1986.

BRASIL, Conama - Conselho Nacional do Meio Ambiente. Resolução n. o 009. Brasília, 1990.

BRASIL, Conama - Conselho Nacional do Meio Ambiente. Resolução n. ${ }^{\circ}$ 010. Brasília, 1990.

BRASIL, CONAMA - Conselho Nacional do Meio Ambiente. Resolução n 001. Brasília, 1987. 
BRASIL, Leis, decretos. Legislação Federal. Lei n. ${ }^{\circ}$ 7.347, de 24 de Julho de 1985, Brasília. 1985. Diário Oficial da União. Disciplina a ação civil pública de responsabilidade por danos causados ao meio ambiente, ao consumidor, a bens e direitos de valor artístico, estético, histórico, turístico e paisagístico (Vetado).

BRASIL. Leis, decretos. Decreto nº 97.632, de Abril de 1982. Brasília: 1989. Diário Oficial da União. Dispõe sobre a regulamentação do artigo $2 .^{\circ}$, inciso VIII, da Lei n. ${ }^{\circ}$ 6.938, de 31 de agosto de 1981.

BRASIL. Leis, Decretos. Decreto no 99.274, de Junho de 1990. Brasília. 1989. Diário Oficial da União. Regulamenta a Lei 6.902, de 27 de abril de 1981, e a Lei 6.938, de 31 de agosto de 1981, que dispõem, respectivamente, sobre a criação de Reservas Ecológicas e Áreas de Proteção Ambiental e sobre a Política Nacional de Meio Ambiente.

BRASIL, Leis, Decretos. Lei n. ${ }^{\circ}$ 6.803, de 2 de Julho de 1980, Brasília: Ministério do Meio Ambiente. 1980. Diário Oficial da União. Dispõe sobre as diretrizes básicas para o zoneamento industrial nas áreas críticas de poluição.

BRASIL, Lei Estadual n ${ }^{\circ}$ 5.457, de 11 de Maio de 1998. Diário Oficial Estadual. Cria a Secretaria de Estado da Ciência, Tecnologia e Meio Ambiente e dá outras providências .www.sectam.pa.gov/lei-5.457.htm (acessado em 12/04/2000), Belém (PA).

BRASIL Lei Estadual $n^{\circ}$ 5.887, de 11 de Maio de 1995. Belém (PA), 1995. Diário Oficial Estadual. Dispõe sobre a participação popular nas decisões relacionadas ao meio ambiente. 
BRASIL, Lei Federal no 6.938, de 31 de Agosto de 1988, Brasília, 1988. Diário Oficial da União. Dispõe sobre a Política Nacional do Meio Ambiente, seus fins e mecanismos de formulação e aplicação.

BURSZTYN. M. (Org.). Para Pensar o Desenvolvimento Sustentável, $2^{\mathrm{a}}$ ed. São Paulo: Brasiliense, 1994. 1v.

CANTER, L. W. Environmental Health Impact Assessment . Pan American Center for Human Ecology and Health. World Health Organization. México. Metepee, 1986.1v.

CRUZ, D.J.M. Sistema de Licenciamento Ambiental e sua Problemática na Estrutura do Estado Composto. A situação Brasileira: reflexos de repartição constitucional de competências. O exemplo das atividades de agronegócios. IN: Anais do $4^{\circ}$ CONGRESSO INTERNACIONAL OFICIAL, 4; Cocal, 2000. p.122153.

COELHO, M. C. N. Impactos Ambientais em Áreas Urbanas - Teorias, Conceitos e Métodos de pesquisa. Rio de Janeiro, In.: GUERRA, A J.; CUNHA, S. B.; Impactos Ambientais Urbanos no Brasil - Bertrand - Rio de Janeiro 1999. 1v.

DENZIN, N. K. Sociological methods. Aldine: Sourcebook Chicago, 1970. 590p.

DIAS, E.,G.C. da Silva. Avaliação de Impacto Ambiental de Projetos de Mineração no Estado de São Paulo: a etapa de acompanhamento. Tese (Doutorado) - São Paulo, 2001. 283p. Escola Politécnica Universidade de São Paulo.

GOUVÊA, Y.M.G. A interpretação do Artigo $2^{\circ}$ da Resolução Conama 01/86. In: São Paulo. Secretaria do Meio Ambiente. Avaliação de Impacto Ambiental. São Paulo, SMA, 1998. v.1, 11-23p. 
INAGÊ, A. Observações sobre a Resolução CONAMA no 237/97. IN: Congresso Internacional de Direito Ambiental. Agricultura e Meio Ambiente, 4., São Paulo, 2000. ANAIS, Local : Editora: Imprensa Oficial, 2000. p.105-122.

JANESICK, V. The dance of qualitative research design. In: DENZIN, N.; LINCOLN, Y. (Ed.) Handbook of Qualitative research. California: Sage, 1994. cap.12. p. 202 -219 .

KENNEDY, W.V. EIA in global perspective: Does is Work? IN: Trabalhos Apresentados NO EIA AS A MANAGEMENT TOOL, Camberra; Editora, 1987.30p.

LAKATOS, E. M.; MARCONI, A.M. Metodologia do trabalho científico: procedimentos básicos, pesquisa bibliográfica, projeto e relatório, publicações e trabalhos, 4.ed. São Paulo: Atlas.1992. 127p.

LAVILLE, C.; DIONNE, J. A Construção do saber: manual de metodologia da pesquisa em Ciências Humanas. Editora: UFMG, 1999. cap.7, p.66-231, Ed. Artes Médicas Sul.; Belo Horizonte:

LAVILLE, C.; DIONNE, J. A Construção do saber: manual de metodologia da pesquisa em Ciências Humanas. Editora: UFMG, 1999. cap. 6, p.131-157, Ed. Artes Médicas Sul Ltda.; Belo Horizonte

LEAL, J. Las Evaluaciones del Impact Ambiental como Metodologias de Incorporacion Del Médio Ambiente en la Planificación. Buenos Aires: ILPES Instituto latinoamericano de Planificacion Econômica y Social, 1985. p. 61-117. 
LÜDKE, M. E; ANDRÉ, M.E.D.A. Pesquisa em educação: abordagens qualitativas São Paulo: Ed. Pedagógica e Universitária, 1986. cap.2, p.203.

MILARÉ, E.; Legislação Ambiental do Brasil. São Paulo, APMP(Série de Cadernos Informativos). 1991. 636p.

MILARÉ, E.; Estudo de Impacto Ambiental no Brasil: Previsão de Impactos Ambientais: O estudo de Impacto Ambiental no Leste, Oeste e Sul. Experiências no Brasil, na Rússia e na Alemanha/Aziz Nacib Ab' Saber, Clarita Muller- Plantebergs (orgs.). - São Paulo: Editora da Universidade de São Paulo, 1998. p.51-83.

MILARÉ, E.; Direito do Ambiente: doutrina, prática, jurisprudência, glossário. São Paulo: Editora Revista dos Tribunais, 2000. 687p.

MACHADO, L. Sociedade urbana, inovação tecnológica e nova geopolítica. Rio de Janeiro,(Cadernos LAGET, nº 5 UFRJ/IGEO) Departamento de Geografia, 1995. 1v.

MARINA, A. M.; EVA, M. L.; Metodologia do trabalho Científico: procedimentos básicos, pesquisa bibliografia, projetos e relatório, publicações e trabalhos científicos. São Paulo; Atlas 1992. 154p.

MOREIRA, I. V. D. Avaliação de impacto ambiental: instrumento de gestão. São Paulo: FUNDAP,1989. p.54-63 (Cadernos Fundap, 16).

MOREIRA, I. V. D., Vocabulário bäsico de Meio Ambiente. Rio de janeiro:Fundação Estadual de Engenharia do Meio Ambiente, 1990, 243p.

MOREIRA, I.V. D. Aplicações de impactos ambientais no Brasil: antecedentes, situação atual e perspectivas futuras. IN: Manual de Avaliação de Impactos Ambientais. (PIAB) . Curitiba - PR, : PIAB 1992. p.1-4. 
MOREIRA, I.V.D. A experiência brasileira em avaliação avaliação de impactos ambiental. In L.E. Sánchez (Org.), Avaliação de Impacto Ambiental: Situação Atual e Perspectivas. São Paulo: Escola Politécnica da USP, 1993a, p.40-45.

MOREIRA, I. V. D. A experiência brasileira em avaliação de impacto ambiental. In: L.E.SÁNCHEZ (Org.), Avaliação de Impacto Ambiental Atual e Perspectivas. São Paulo: Escola Politécnica da USP 1993. p. 39-45.

MONOSOWSKI, E. Avaliação de Impacto Ambiental na Perspectiva do Desenvolvimento Sustentável. In: L.E. SÁNCHEZ: L.H (Org.), Avaliação de Impacto Ambiental: Situação Atual e Perspectivas, EPUSP, São Paulo: Escola Politécnica da USP. 1993, p. 3-10.

MINERAÇÃO SERRA DO SOSSEGO, Sistema de gestão Ambiental - SGA.MSS. Rio de Janeiro: MSS, 2001.43p.

MINERAÇÃO SERRA DO SOSSEGO (2000a) - Planos de Controle Ambiental PCA. (Vários Programas.) Rio de Janeiro: MSS, 2001. 24p.

MINERAÇÃO SERRA DO SOSSEGO. Estudo de Impacto Ambiental - EIA, V. 123, 2000, Rio de Janeiro - MSS, 2000, 398p.

MINERAÇÃO SERRA DO SOSSEGO. Relatório de Impacto Ambiental - RIMA, Volume I, Rio de Janeiro: MSS, 2000. 31p.

MINERAÇÃO SERRA DO SOSSEGO. Plano de Desenvolvimento Sustentável PCA, Volume 23. Rio de Janeiro 2001. 1-70p. 
NOSSO FUTURO COMUM/Comissão Mundial sobre Meio Ambiente e Desenvolvimento. 2.ed - Rio de Janeiro: Editora da Fundação Getulio Vargas, 1991.V.18, 430p.

PATTON, M.Q. Qualitative evaluation and research methods. Beverly Hills, Calif., Sage Publications, 1980. p. 98-107

PIRES DO RIO, G. A.; GALVÃO, M.C.C Gestão Ambiental: Apontamentos para uma reflexão. Rio de Janeiro. Editora: Lua Nova n.36 1997. p.105-138.

RATTNER, H. Tecnologia e Desenvolvimento Sustentável In: Desenvolvimento Sustentável: Um novo caminho. Belém: NUMA/UFPA, 1992. 34-35p.

RODRIGUES, M; A. Efeitos da Gestão Ambiental das empresas mínero-metalúrgica da Amazônia Oriental (Estado do Pará). ENCONTRO NACIONAL SOBRE GESTÃO EMPRESARIAL E MEIO AMBIENTE; São Paulo, 1999, Anais, São Paulo: FEA/USP, 1999. p. 519-534.

SADLER, B., org. Environmental assessment in a changing world: evaluating practice to improve performance. S. L. International Association for Impact Assessment / Local: Canadian Enviromental Assessment Agency, 1996. 248p.

SANTOS, E. C. Avaliação de Impacto Ambiental (AIA) e sua utilização como processo/instrumento de gestão ambiental do desenvolvimento sustentável de projetos de mineração no Estado do Pará. O caso do projeto Pará Pigmentos S/A. Belém, 1999.186p. Tese (Doutorado) - Núcleo de Altos Estudos Amazônicos, Universidade Federal do Pará. 
SÁNCHEZ, L. E.; Os Papéis da Avaliação de Impacto Ambiental In: SÁNCHEZ, (Org) Avaliação de Impacto Ambiental: Situação e Perspectivas. São Paulo, EDUSP, 1993. p. 15-33.

SÁNCHEZ, L. E. As etapas iniciais do processo de avaliação de impacto ambiental. São Paulo: SMA, 1998. v.1, p.35-55.

SÁNCHEZ, L. E. O processo de avaliação de impacto ambiental. seus pápeis e funções. A efetividade da avaliação de impacto ambiental no Estado de São Paulo: uma análise a partir de estudos de caso. São Paulo: SMA, 1995a. p. 9-13.

SÁNCHEZ, L. E. Os papéis da avaliação de impacto ambiental. In. L.E. SÁNCHEZ (Org.), Avaliação de Impacto Ambiental e perspectivas. São Paulo:EDUSP,1993. $166 \mathrm{p}$.

SECRETARIA EXECUTIVA DE CIÊNCIA TECNOLOGIA E MEIO AMBIENTE. Parecer Técnico sobre o projeto da Mineração Serra do Sossego. Belém: SECTAM/PA, Divisão de Projetos Minerários, 2001. p.40 (Parecer técnico apresentado ao Conselho de Meio Ambiente- COEMA, Pará).

SILVA, E; SILVA, C. L.Técnicas de Avaliação de Impactos Ambientais. Viçosa: Minas Gerais, CPT - www.cpt.com.br, Publicação no 199, 2002, 1-7p (16/6/2002).

TOMMASI, L. R.; Estudo de Impacto Ambiental;: Ed. Terragraph Artes e Informática, São Paulo: CETESB, 1993. p.45-50.

VAN ACKER, F.T. Os estudos de impacto ambiental: da Resolução 1/86 à Resolução 237/97 do Conama. In: São Paulo. Secretaria do Meio Ambiente. Avaliação de impacto ambiental. São Paulo, SMA, 1998. v.1, p.25-29. 
WESTPHAL, M.F. Participação popular e políticas municipais de saúde: o caso de Cotia e vargem Grande paulista. São Paulo, 1992. p.2 Tese (Livre-Docência) Faculdade de Saúde Pública, Universidade de São Paulo.

YIN.R.K. Case study research: design and methods. Trad. de R. L. Pinto. http://wwww. fea.usp.br/metodologia/estudo_caso. asp/ (21 nov 2001).

ZIONI, F. Pesquisa participante: relato e avaliação de uma experiência de pesquisa social. São Paulo, 1994 (Tese de Doutorado) Faculdade de Saúde Publica, Universidade de São Paulo. 1v.

WWW. unioeste.br/agais/impacto.html .(16 jun. 2002) p.1-7.

WWW1.ibge.gov.br/cidadesat//xtras/temas.php?nomemun (15/06/03). p.1-7. 
APÊNDICES 


\section{APÊNDICES 1 O processo de licenciamento ambiental (EIA/RIMA): retrato cronológico}

Em novembro de 1999, foi solicitada e posteriormente realizada, uma reunião no prédio da SECTAM em Belém, envolvendo representantes da empresa Vale do Rio Doce, BRANT Consultoria e SECTAM. O Objeto desta reunião foi à discussão a respeito dos procedimentos a serem adotados para se proceder as fases do licenciamento ambiental do Projeto de exploração de Cobre de responsabilidade da empresa Mineração Serra do Sossego, a ser implantado no Município de Canaã dos Carajás.

Em 15/02/2000 foi apresentada a SECTAM e protocolado sob o $n^{0} 26.170 / 00$ Carta Consulta acompanhada do documento intitulado Estudo de Avaliação Ambiental e Licenciamento - Termo de Referência para elaboração do EIA/RIMA.

Em 02/03/2000 foi realizada uma reunião técnica na SECTAM objetivando avaliar o conteúdo da documentação acima, sendo que na oportunidade foi informado à empresa que o mesmo atendia às exigências técnicas, estando de acordo com a legislação ambiental em vigor.

Em 03/04/2000 foi protocolado na SECTAM sob o $\mathrm{n}^{\circ}$ 57869/2000 a documentação relativa ao Estudo de Impacto Ambiental - Relatório de Impacto Ambiental (EIA/RIMA).

Em 10/04/2000 a SECTAM pública no Diário Oficial do Estado e no jornal O Liberal, o Edital informando que encontrá-se à disposição na biblioteca do órgão à documentação relativa aos Estudos de Impacto Ambiental e Relatório de Impacto Ambiental EIA/RIMA, referentes ao processo de licenciamento ambiental do projeto Mineração Serra do Sossego.

Em 13/04/200 é encaminhado sob o protocolo SECTAM n 68.255/2000, a solicitação para convocação de audiência pública referente ao projeto "Mineração Serra do Sossego" em Canaã dos Carajás pela Comissão de Meio Ambiente da Organização dos Advogados do Brasil $(\mathrm{OAB})$.

Em 25/04/2000, através do protocolo $n^{0} 57.869 / 2000$ é encaminhada a SECTAM uma cópia da correspondência enviada à Superintendência de Licenciamento e Controle da Comissão de Energia Nuclear (CNEN), juntamente com os Estudo sobre Radionuclídeos do Projeto Sossego.

Em 22/05/200 é encaminhado a SECTAM sob o protocolo $n^{\circ} 96.342 / 2000$, a solicitação de Audiência Pública referente ao Projeto Mineração Serra do Sossego" em Canaã dos Carajás, pela Associação Ambientalista da Amazônia (ARGONAUTAS). 
Em 22/05/2000 foi apresentado pela Diretoria e Técnico da Empresa Mineração Serra do Sossego, pela equipe da BRANT Meio Ambiente e pela diretoria da SANDEL Projetos e Serviços, no Auditório desta Secretaria a concep̧̧ão do empreendimento.

No período de 23 a 25 de maio de 2000, foi realizado pelo corpo técnico da SECTAM, responsável pelas análises do EIA/RIMA vistoria técnica ao local de implantação do Projeto Sossego.

Em 25/05/2000, foi encaminhado pela Divisão de Análises de Projetos Minerários da SECTAM, correspondência à Superintendência de Licenciamento e Controle da Comissão de Energia Nuclear (CNEN), solicitando posicionamento técnico a respeito dos Estudos realizados sobre Radionuclídeos do Projeto Sossego.

Em 01/06/2000 durante uma reunião na sede da SECTAM, foi marcada a Audiência Pública relativa ao empreendimento, objetivando informar à comunidade acerca da implantação do mesmo naquele município e seus respectivos impactos ambientais, bem como possibilitar a discussão e o debate sobre o RIMA, a ser realizada no dia 28/06/2000, às 19:30 h na sede daquele Município.

Em 15/06/200 é encaminhado pela Superintendência de Licenciamento e Controle da Comissão de Energia Nuclear o Of.085/SLC assinado pelo Superintendente do órgão, tendo-se em anexo uma cópia do parecer técnico do geólogo Mário Osvaldo Fraenkel, onde o mesmo conclui "dentro das perspectivas de radioproteção e do monopólio estatal sobre os materiais nucleares, confirmam que o projeto pode ser implementado. Entretanto, como grande parte dos estudos realizados na fase de projeto estão baseados em amostras de testemunhos de sondagens, os responsáveis deverão manter informada a CNEN do avanço da implantação e do início da operação, para permitir a programação de fiscalização por parte desta comissão". No mesmo expediente é recomendado que: "os resultados obtidos no Programa Pré-Operacional de controle ambiental relacionado à presença de Radionuclídeos sejam enviados para avaliação desta CNEN".

Nos dias 21, 23 e 26/06/2000 foi publicada no Diário Oficial da União (DOU) e nos dias $21,22,23 / 06 / 2000$ foi publicada no jornal de O Liberal, a convocação para a supracitada Audiência Pública.

A audiência pública foi realizada no dia 28 de junho de 2000, na sede da Escola Municipal Tancredo de Almeida Neves no município de Canaã dos Carajás, tendo integrado a mesa representantes do Governo do Estado, Vice-Governador Hildegardo de Figueiredo Nunes, os Deputados Estaduais Cláudio Almeida e Faisal Salmen, o Prefeito Municipal de Canaã dos Carajás Sebastião Bruno Pereira, o Presidente da Câmara do município Vereador Luís Donizete 
dos Santos, a Promotora de Justiça de Parauapebas Dr. ${ }^{a}$ Ioná Souza, o Procurador do Ministério Público em Canaã dos Carajás Dr. João Ferreira da Silva, o representante da OAB Dr. Rômulo Andrade Nascimento e o representante legal da empresa Rafael Bloise. Inicialmente, houve a exposição do projeto seguido da manifestação de representantes das várias entidades governamentais presentes, bem como da sociedade civil, percebendo-se que as questões sempre se relacionavam com destaque da importância do empreendimento para o desenvolvimento da região, geração de emprego e renda, bem como o anseio da população pela sua implantação. Foi ressaltado também pelos presentes, que se manifestaram, as obras de melhoramento e/ou implantação de novos acessos à região.

Após a Audiência Pública foi elaborado o parecer técnico que posteriormente foi encaminhado a Câmara Permanente de Projetos Minerários e Recursos Hídricos que considerou o estágio em que se encontram as iniciativas voltadas para o integral cumprimento de todas as exigências e recomendações do Conselho Estadual do Meio Ambiente para efeito de autorização da concessão de Licença Prévia para o projeto Mineração Serra do Sossego S.A, considerando ainda que dentre aquelas exigências e recomendações, as dizem respeito mais diretamente ao diagnóstico ambiental estão amplamente atendidas.

O Conselho de Meio Ambiente manifestou seu voto favorável à concessão da Licença solicitada pelo empreendedor e recomendaram aos senhores membros do COEMA que aprovem a concessão da Licença Prévia para o projeto Mineração Serra do Sossego S.A em 19/10/2000. Foi encaminhada uma notificação para empreendedor com prazo de 15 dias para retirada da Licença Prévia. A Licença foi expedida em 25/10/2000, com validade de até 31/10/2001. Conforme estabelece a "Resolução CONAMA n 06, de 24.01 .86 a referida licença deverá ser publicada num prazo de 30 (trinta) dias". No processo da Mineração Serra do Sossego não consta cópia da publicação da licença. Esta licença possui condicionantes.

No dia 08/11/2000 a SECTAM, encaminhou a Mineração Serra do Sossego uma notificação n ${ }^{\circ}$ 1858/00, da Coordenadoria de Avaliação de Projetos (CODAP/SECTAM), sob o $n^{0} 57.869 / 00$, após análise da documentação apresentada e vistoria no local do empreendimento e manifestação do Conselho Estadual de Meio Ambiente (COEMA), a empresa teria que cumprir algumas determinações, durante a vigência da licença e antes da solicitação da Licença de Instalação.

Durante a vigência da Licença Prévia e em atendimento ao "Art. $8^{\circ}$, inciso II da Resolução CONAMA 237/97, de 19/12/1997, apresentou o Relatório de Controle Ambiental e outros documentos, num total de 21 volumes, protocolados sob $n^{\circ} 57.869 / 2000$ de 14/03/2001, relativo à 
atividade de lavra e beneficiamento de minério de cobre numa "paragênese sulfetada", objetivando a concessão de Licença de Instalação (L.I.), para a implantação do Projeto Sossego - minas do Sossego e Sequeirinho, localizadas no município de Canaã dos Carajás, destacando-se que o mesmo abordará nessa fase: Acampamentos de obra; Mina (cava Sossego e Sequeirinho); Unidade de beneficiamento mineral (planta de concentração e utilidades); Escritórios administrativos; Depósitos de estéril e de resíduos, Barragem de rejeitos, ETE's; Estrada de acesso e de ligação entre Parauapebas e Canaã dos Carajás; Linha de transmissão de energia elétrica; Estação de embarque de concentrado em Parauapebas. 


\section{APÊNDICES 2 Análise do parecer da secretaria executiva de ciência, tecnologia e meio ambiente (SECTAM)}

\subsection{Licença prévia}

A SECTAM emitiu Relatório consubstanciado a respeito da implantação do "Projeto de Exploração e Benefíciamento Mineral" a MSS, visando a concessão da Licença Prévia. O Conselho Estadual de Meio Ambiente (COEMA), exarou Parecer Técnico favorável ao Processo 57.869/2000 (EIA/RIMA) da MSS.

A SECTAM considerou atendidas as Resoluções do CONAMA regulamentadoras do licenciamento. A Secretaria processou um breve resumo do histórico do licenciamento, desde a exposição oral de representantes da empresa até a audiência pública ocorrida em Canaã dos Carajás, tendo a equipe técnica do órgão vistoriado a área do empreendimento, onde constatou a viabilidade do projeto.

Apesar de revelar satisfatórios os planos, programas e projetos do EIA/RIMA, a SECTAM registrou ressalvas quanto a algumas particularidades/especificidades da situação atual do empreendimento, devido a lacunas de informações como, por exemplo, a destinação da camada do solo vegetal existente dentro da área da barragem, o sistema de drenagem dos resíduos sólidos gerados nas operações de lavra, melhor detalhamento sobre os depósitos e aterros sanitários, informes minuciosos do plano de monitoramento, a falta de dados estatísticos no levantamento socioeconômico em Canaã de Carajás e Parauapebas e carência de informações no setor segurança pública.

O Relatório da SECTAM discorda da avaliação do EIA/RIMA considerar impacto de intensidade média, reputando-o, enfaticamente, de alta intensidade, em razão da gravidade dos efeitos do empreendimento na qualidade de vida das populações envolvidas.

O documento elenca uma série de exigências e recomendações que deveriam ser observadas quando da elaboração do Plano de Controle Ambiental da MSS. Dentre às exigências (29) inclui o detalhamento dos Programas e Planos do Plano de Controle Ambiental e de todas as propostas constantes do EIA/RIMA e outros como projeto executivo dos diques filtrantes, plantas topográficas, projeto executivo da Estação de Tratamento de Água (ETA) e Plano de emergência para as atividades periculosas. No bojo das 7 recomendações preconiza, entre outras, que o Programa de Inserção Social contemple projetos infra-estruturais da Área Influência Direta e prioridade à mão-de-obra. 


\subsection{Licença de instalação}

A MSS, no propósito de obter junto a SECTAM a concessão de Licença de Instalação para a Implantação do Projeto Sossego submeteu à apreciação daquela Secretaria o Plano de Controle Ambiental (PCA), com um montante de 23 volumes, os quais foram objetos de análise.

O órgão oficial considerou atendidas as exigências contidas na notificação 1858/2000 (CODAP/SECTAM), no item 1 (programas e planos do PCA); no item 2 (detalhamento das propostas integrantes do EIA/RIMA); item 3 (desassoreamento das margens e leitos dos córregos); item 4 (drenagem na vegetação marginal); os itens 5, 6 e 7 e 20 as informações sobre destinação do material escavado e estudos hidrogeológicos e diagnóstico faunístico não satisfizeram os analistas. Contudo, foram consideradas satisfatórias as providências correspondentes ao item 8 (destino do material oriundo do desmatamento/decapeamento); item 15 (medidas compensatórias e/ou mitigadoras de preservação/conservação da FLONACA); item 16 (projeto executivo da estação de tratamento de água - ETA); item 21 (cultivo de mudas); item 22 (meios compensatórios de revegetação das áreas degradadas entorno do projeto e da FLONACA); item 23 (plano de emergências às atividades periculosas); item 11 (projeto executivo dos diques filtrantes); item 12 (sistema de drenagem dos depósitos de cobre oxidado).

Em seguida, o Relatório emite apreciações mais específicas a respeito de alguns programas e planos, a saber:

\section{Programa de relocação}

Inicialmente, o órgão questionou a insuficiência de informes e comprovantes da documentação referente a relocação dos moradores da ADA. Posteriormente, a MSS sanou as falhas detectadas ao apresentar documentos como: Laudo de Avaliação dos lotes indenizados, cadastro socioeconômicos, comprovantes dos valores indenizatórios por propriedade e do novo endereço das pessoas indenizadas.

\section{Programa de compensação, inserção e comunicação social}

A SECTAM, ao analisar referido Programa, não o reconheceu como tal "e sim linhas de ação e diretrizes" do mesmo. Recomenda algumas ações como a criação do Conselho Municipal de Meio Ambiente e implantação de uma Unidade de Conservação em área fora da FLONACA. 


\section{Programa do plano de socioeconômico}

A SECTAM enfatizou algumas ressalvas quanto ao Plano de Monitoramento Socieconômico, discordando, por exemplo, da periodicidade do censo (semestral em vez de anual) na fase de implantação (bianual e não anual nos 2 primeiros anos e, posteriormente qüinqüenal). Critica a ausência de convênio para viabilizar as campanhas censitárias, e sugerem, ainda, que a MSS apresente projetos de alternativos de ocupação e renda aos recursos humanos não absorvidos pelo empreendimento.

\section{Programa de prospeç̧ão e salvamento arqueológico}

A SECTAM censura a não inclusão de cópia do convênio celebrado entre a MSS/FADESP/MPEG para cumprir supracitado Programa, assim como cópia da autorização concedeu pelo IPHAM a MSS.

\section{Programa de controle de decapeamento e minimização de desmate}

A SECTAM reservou-se a comentar as características do Programa, sem anotar quais restrições ou recomendações.

\section{Programa de controle de drenagem e contenção de finos}

A Secretaria considerou atendidas suas exigências quanto ao projeto executivo dos diques filtrantes e ao sistema de drenagem dos depósitos de cobre oxidado, o único senão observado pela SECTAM é que o plano se atém somente às obras preliminares de infra-estruturais é de terraplenagem.

\section{Plano de gerenciamento de águas e controle de efluentes líquidos}

Em longa análise a SECTAM limita-se a esmiuçar as estratégias da empresa em viabilizar o Programa em consonância com os padrões estabelecidos pela Resolução CONAMA 020/86. 


\section{Programa de controle de emissões atmosféricas}

A SECTAM não emitiu nenhuma objeção aos sistemas a serem implantados, executados e dimensionados com o fato de manter as emissões atmosféricas aos níveis impostos pela legislação vigente.

\section{Programa de controle e manutenção de veículos e equipamentos}

A Secretaria discorre de forma detalhada sobre os procedimentos que a MSS vai adotar para operacionalização do Programa, sem detectar quaisquer restrições de ordem técnica ou legal.

\section{Programa de controle de obras de terraplenagem}

A SECTAM manifesta-se sobre a "necessidade de uma fiscalização eficaz nas empreiteiras" e que a MSS deveria processar a plotação e/ou a localização/delimitação das áreas de empréstimo à reabilitação da estrada que liga a mineração a Parauapebas.

Finalmente, a SECTAM preconiza que a MSS deverá cumprir as propostas/medidas de controle contidas no PCA, apresentar os resultados das pesquisas geológicas no Sossego e Sequeirinho e os resultados dos estudos processados nos alvos Serra Dourada e Canadá na periodicidade trienal. Recomenda, ainda, pesquisa sobre ocorrência de fosfato, alumínio, cádmio e manganês nos limites estabelecidos pela Resolução CONAMA 020/86 para águas da Classe II (no caso águas do rio Parauapebas), a criação do Conselho Municipal de Meio Ambiente em Canaã dos Carajás, e a elaboração a partir do $3^{\circ}$ ano da implantação do empreendimento de projetos de interesse da comunidade inseridos no Programa de Educação Ambiental. 


\section{APÊNDICES 3 Análise das medidas mitigadoras e compensatórias}

Este item visa analisar as medidas mitigadoras e compensatórias que foram apresentadas no EIA/RIMA, para os impactos prognosticados na fase de Avaliação de Impacto Ambiental, especificamente a parte sócio-ambiental de acordo com a formação da autora.

Para cada impacto diagnosticado foram apresentadas medidas mitigadoras, de reabilitação ou de compensação; além destas medidas, são consideradas também as medidas de incremento aos impactos positivos, e os programas de monitoramento, que tem o objetivo de aferir a eficácia dos programas de mitigação adotados.

Foram elaborados 23 (vinte três) Programas de Controle Ambiental pela MSS, os quais juntos com outras informações complementares oriundas da Licença Prévia, foram apresentados a SECTAM, para obtenção da Licença de Instalação. O Plano de Controle Ambiental constituem-se de conjunto de programas minimizadores, potencializadores e/ou compensatórios aos impactos, incluindo os sociais, resultantes das principais alterações prognosticadas pelo EIA/RIMA. Trata-se de uma exigência legal, prevista no processo de licenciamento pelo órgão ambiental responsável pela licença, cabendo a este a fiscalização e o monitoramento da execução do plano.

Usualmente as sociedades locais têm pouco ou nenhum conhecimento sobre o Plano de Controle Ambiental dos empreendimentos. As ações de relacionamento com a sociedade são geralmente tecnocraticas e focadas nas questões de ganho econômico e/ou nos benefícios que o empreendimento mineiro traz ao município, sem preparar a comunidade para os impactos gerados quando do encerramento das atividades. Neste sentido, a Mineração Serra do Sossego apresentou várias propostas, para serem executadas juntamente com a sociedade, contribuindo provavelmente para uma conscientização, e para que a população assuma um maior papel nessa conjuntura. Neste item específico são analisados os seguintes programas a seguir:

\section{1 - Programa de compensação, inserção e comunicação social}

\section{Considerações Gerais}

O programa apresenta como objetivo "inserir a MSS na Sociedade de Canaã dos Carajás apoiando seu desenvolvimento sustentável de forma a capitalizar os efeitos positivos da implantação do empreendimento, e a minimizar os potenciais efeitos negativos advindos desta." (Programa de Compensação, Inserção e Comunicação Social, 2001). 
Entre os efeitos positivos, o programa reconhece o aumento da carga tributária que poderá atender o aumento da demanda sobre a estrutura urbana e outros serviços públicos. Acompanhada por uma devida assessoria técnica, seria possível que a cidade alcançasse um "novo patamar de desenvolvimento". Assim, propõe-se a "pensar essa nova cidade" e a contribuir para que esse planejamento seja feito com participação dos diferentes setores da população, sendo que essa posição vai ao encontro da literatura científica sobre o tema assim como atenderia às atuais recomendações de caráter internacional, técnico e político sobre atuação na gestão e controle ambiental.

\section{Análise por itens}

A) - No item "2.3 - metodologias e técnicas participativas a serem utilizadas", são apresentados os pressupostos teóricos que orientariam a estratégia de trabalho preconizada. Esses pressupostos estariam baseados em conceito denominado pelos autores de "Mobilização Social" ou seja "o conceito estrutural dessa abordagem é a participação motivada por convicção pessoal e identificação grupal e, se é assim, todo trabalho proposto deverá ser de estímulo, facilitação e assessoria ao desenvolvimento pela comunidade, de ações que concretizem objetivos por ela mesma estabelecidos". (Programa de Compensação, Inserção e Comunicação Social, 2001).

Esse conceito, apresentado sem referência bibliográfica e sem a devida teorização apesar de se intitular "social", repousa, até onde se pode analisar pela brevidade da exposição, de maneira acentuada, em dimensões individuais e de caráter pessoal, afetivo, psicológico da participação. Coloca a possibilidade, a opção pela participação em espaços públicos, coletivos, sociais, como decorrente de processos e fatores mais psicológicos (convicção) do que sociais. Esse conceito (ou definição) apesar de reconhecer a necessidade de uma identidade grupal passa ao largo de considerações importantes, desenvolvidas pela sociologia, antropologia e psicologia, sobre o conceito de identidade e a própria construção de uma identidade coletiva, que abarca mais do que uma decisão individual, uma escolha pela participação.

A questão da participação popular tem sido mais reconhecida e discutida cientificamente do que realmente promovida.

De acordo com o filósofo alemão Habermas, autor bastante divulgado e reconhecido pela comunidade científica, existe uma oposição na sociedade contemporânea, entre a esfera do mundo da vida e aquela do sistema (Zioni, 1994). 
Por "mundo da vida", entende-se o espaço das relações cotidianas, pessoais, culturais: família, vizinhança, lazer, sociabilidade. Por "sistema" entende-se o espaço das relações técnicoburocráticas das empresas, das estruturas estatais. A linguagem do mundo da vida seria a da cultura, sua ação, ação comunicativa. A linguagem do sistema seria a científica, técnica, sua ação, a ação instrumental. Dada ao seu melhor desempenho lingüístico e poder econômico, os sistemas tenderiam a "colonizar" o mundo da vida, impondo sua lógica à sociedade como um todo.

Segundo essa interpretação, um grande empecilho à participação repousaria na dificuldade argumentativa dos elementos, dos grupos dos atores sociais que compõem o mundo da vida. Para superar isso, movimentos sociais, ONGs, programas de governo e projetos de intervenção social deveriam investir na ampliação e/ou criação de um espaço em que as competências argumentativas fossem desenvolvidas pelos diferentes grupos e segmentos populacionais que compõem uma sociedade, uma municipalidade, grupos esses que vivem, em sua maioria, relações assimétricas em termos econômicos, educacionais, políticos, etc.

Apesar de se preocupar em adotar técnicas e metodologias de ação que fomentassem a participação apesar de propor uma técnica que se apresenta como bastante legitimada pelo emprego na área ambiental, a proposta de operacionalização (conforme o apresentado nos itens e sub-itens apresentados em 2.1 - Operacionalização) pode ser considerada insuficiente e inadequada para atender às necessidades de promoção de projetos realmente participativos.

\section{B) - Análise do item 2.1.1 - identificação e sensibilização:}

Para promover o reconhecimento de "todos os grupos de interesse e sensibiliza-los com a proposta da MSS e com o Programa de Compensação, Inserção Comunicação Social”, propõese o levantamento (através de pesquisa de campo) das instituições, associações, lideranças formais e informais, etc..), assim como a realização de entrevistas com seus principais componentes, a fim de se promover uma reunião na qual haveria a apresentação formal do programa assim como o planejamento para Mobilização e Apoio Técnico para Elaboração do Desenvolvimento Participativo e Sustentável de Canaã dos Carajás. Nessa ocasião estimular-se-á a "participação de todos".

Além dessas ações de divulgação seriam formados grupos "representativos" da área pública e privada, de diversos setores - educação - saúde- comércio - agricultura, etc.. que teriam a responsabilidade de repensar a estrutura de suas atitudes. 
Essa proposta, além de ignorar as dificuldades, no campo da comunicação e organização social, no que diz respeito à possibilidade concreta de se efetivar essa reunião, desconhece as relações de poder existentes em todos os grupos sociais, as dificuldades advindas das relações sociais assimétricas para a efetiva participação de todos os "grupos de interesse de Canaã dos Carajás". Sendo assim, corre-se o risco de se promover uma reunião que privilegie determinados setores em detrimento de outros. A falta de pluralidade no início do projeto pode comprometer todo seu desempenho.

Para atender essa questão - composição plural dos participantes em um projeto de intervenção - existem algumas experiências desenvolvidas por projetos acadêmicos, por movimentos sociais e ONGs, que utilizam na fase de levantamento de informações, de diagnósticos socioeconômicos e de saúde, como forma de envolvimento da população, de sensibilização para a participação.

Essas experiências utilizam-se de recursos de investigação baseados na experiência da antropologia (observação participante, autocenso, procedimentos antropológicos rápidos, estimativa rápida, grupos foco, etc..) que, desde que aplicados no início, podem alcançar setores da população que normalmente não participam de grupos formais, associação de interesse, etc.. (Westphal, 1992).

Esse mesmo tipo de procedimento poderia ser aplicado para a realização das outras etapas: diagnósticos setoriais, agenda 21 , criação de conselhos, etc.

A participação dos grupos sociais de maneira mais sistemática e menos dirigida é extremamente positiva para a elaboração de propostas, programas alternativos de geração de renda, de atuação coletiva na recuperação ambiental, etc. Diversos projetos desenvolvidos em áreas críticas com financiamentos internacionais reforçam essa afirmação.

Para se garantir a participação plural no projeto, envolvendo população de baixa renda, população rural, etc., são necessários, além desse procedimento inicial, cursos, oficinas e várias iniciativas para a formação e capacitação dos grupos, iniciativas essas que não foram mencionadas no programa em análise.

$\mathrm{Na}$ área da saúde e de desenvolvimento rural, já existem, há muito tempo, experiências de cursos e formação de conselheiros assim como atividade de dinâmica de grupo (grupos de sensibilização, grupos de desenvolvimento de auto-estima) que podem ser reproduzidos em Canaã dos Carajás, principalmente entre grupos de mulheres. A participação de mulheres em grupos de moradores, associação de artesãos, conselhos de saúde, etc.., tem se destacado como 
significativa do ponto de vista numérico e, vale lembrar, extremamente positiva. Por esse motivo, organismos internacionais como o Banco Mundial, a Agência de Cooperação Canadense, etc., muitas vezes condicionam o financiamento de projetos dando atenção especial à questão de gênero. Vale lembrar que esse aspecto não foi, também, apresentado pelo projeto.

\section{C) - Análise do item 2.2 - acompanhamento da atividade do conselho}

No que diz respeito a esse item, o programa prevê que a equipe técnica acompanhe e apóie o conselho durante um período de 6 meses. Esse apoio, por sua vez, constituir-se-ia em reuniões mensais cujo conteúdo, objetivos, dinâmica, etc.., não foram detalhados.

No que se refere à criação de Conselhos, vale lembrar que experiências recentes têm mostrado como esse processo pode ser bastante pedagógico tanto no sentido de formar pessoas para trabalharem no conselho como por processo de eleição dos conselheiros. Esse aspecto também não é apresentado no programa.

A SECTAM no seu parecer técnico apenas recomenda a criação do Conselho Municipal de Meio Ambiente, que seria um órgão consultivo e deliberativo, composto por representantes dos vários seguimentos da sociedade local, e que a comissão municipal de desenvolvimento seja composta por membros do referido conselho pelo qual deve ser referendada.

Numa solicitação anterior o órgão ambiental, sugeriu à empresa que apresentasse neste programa projetos de apoio à infra-estrutura dos municípios da AID, através do estabelecimento de convênio com entidades públicas e privadas. Não foram apresentados esses projetos e nem foram estabelecidos os convênios, até o momento do levantamento de dados. O órgão espera que esses projetos e convênios sejam implantados e firmados durante o desenrolar dos vários programas e na construção do Plano de Desenvolvimento Sustentável da micro-região, assim como sejam apresentados projetos de alternativas de geração de ocupação e renda que vão ajudar a minimizar os problemas do contingente de pessoas que não serão absorvidas pelo empreendimento e certamente enfrentarão vários tipos de problemas sociais, e causarão muitos outros.

Apresenta, também, de forma detalhada, todos os procedimentos operacionais para o período anterior à implantação, para o período de implantação, operação e fechamento do projeto.

No entanto, deve-se atentar cuidadosamente para os seguintes aspectos:

A especificidade do público alvo que não é homogêneo, exigindo abordagens diferenciadas. Ou seja, considerar as diferenças de tratamento entre a população local (Canaã 
dos Carajás), que precisa ser inserida neste cenário de mudança, e a população decorrente do fluxo migratório que precisa ser absorvida e adaptada às realidades sócio-culturais locais, conforme mencionado na página 5 do documento - Programa de Comunicação Social;

A questão regional dos municípios da Área de Influência Indireta (AII) com baixo nível de integração e falta de preparo para o exercício da cidadania, por serem novos (cerca de 20 anos de criação);

Geração de forte fluxo migratório sem raízes e compromissos com o local e com o coletivo (o Município de Canaã dos Carajás com cerca de 13.398 habitantes, deverá receber 9000 pessoas em disputa pelo 3000 empregos a serem gerados);

Necessidade de criação de condições para o enfretamento de divergências de várias ordens (objetivos, interesses, métodos de abordagem, etc.) através de processos de negociação continuada entre os grupos;

As diferenças de interesse e relacionamento com o local apontam para a necessidade de diferenciação de procedimentos em termos de envolvimento e estímulo à participação, de linguagem e, principalmente, dos meios de transmissão de mensagens, o que pressupõe um estudo detalhado do público alvo, realizado por profissionais especializados, com sociólogos, psicólogos, educadores e comunicadores sociais. É preciso cuidar para que não haja transferência de procedimentos padronizados, buscando, ao contrário, responder mais adequadamente aos condicionantes locais.

Com relação à Operacionalização do Programa de Compensação, Inserção e Comunicação Social, quando este se refere à "criação de grupos de discussão setoriais (saúde, saneamento, educação, transporte, comércio, prestação de serviços, infra-estrutura urbana, visando à identificação das necessidades setoriais dos municípios, sua priorização e formulação de diretrizes básicas para a formulação de políticas setoriais", não foi considerada a necessidade de uma visão e operacionalização sistêmica das questões urbanas a serem tratadas com racionalidade estratégica, isto é, uma integração entre os diversos setores que não podem ser tratados de forma isolada, como por exemplo, educação e saúde. Todos mantém fortes relacionamentos.

Devem ser estimuladas outras formas de discussão que conduzam à descoberta e à constatação da importância destas relações, como: perfil econômico (geração de emprego e renda); gestão social (educação, saúde, lazer, etc.): políticas urbanas (usos e ocupação, proteção ambiental, etc.) dentre outras, mais de acordo com as demandas e linguagem locais. 
Outro aspecto discutível é a transferência de formas tradicionais de planejamento urbano com seus instrumentos normativos, numa área de extrema dinâmica, ainda que temporariamente. Os instrumentos urbanísticos também devem ser pensados de forma a orientarem e se anteciparem às demandas.

A utilização de elemento do planejamento estratégico, brevemente mencionado no mesmo documento, sobre vantagens e desvantagens, oportunidades e ameaças, deve ser fortemente considerada e sempre reforçada pela análise regional.

Finalmente com relação aos impactos socioeconômicos, um empreendimento de caráter temporário induz nas pessoas a noção de oportunismo, essa especulação e a ausência da intenção de criar raízes, além da falta de cuidado com o lugar. Neste sentido, as políticas de desenvolvimento econômico e social devem buscar locais, elementos que possam promover um desenvolvimento sustentável, não apenas para a cidade de Canaã dos Carajás, mas também para a Área de Influência Indireta (AII). A força de atração do empreendimento promove esvaziamento do entorno e congestionamento do centro. Medidas no sentido de diminuir o êxodo localizado (concentrado em determinados pontos) deveriam ser tomadas por meio de um planejamento regional, reforçando aqui também, um caráter sistêmico de análise e intervenção.

É fundamental também uma política de planejamento regional, pois políticas municipais isoladas e diferenciadas promovem desequiilíbrios de fluxos e demandas das mais variadas ordens.

Nos anos 80 uma série de encontros internacionais visando a melhoria da qualidade de vida, a extensão dos serviços de saúde, o encaminhamento da questão urbana, o enfretamento da questão urbana, o enfretamento da pobreza, principalmente na área rural, acabaram por desenvolver uma conceituação, uma reflexão teórica, que desembocou em uma proposta de intervenção social, num método de trabalho que tem se revelado bastante útil no encaminhamento destes problemas, inclusive no que tange à área ambiental.

Essa proposta, denominada "Municípios Saúdaveis" é um dos exemplos de intervenção que poderiam ter sido lembrados nesse documento. Outra proposta interessante para Canaã dos Carajás voltada mais especificamente para área de saúde (sem inviabilizar alternativa de municípios saudáveis), seria desenvolver uma consultoria e assessoria às instituições locais e, principalmente, à administração municipal, para adoção do Programa Saúde da Família. Esse programa tem sido apontado como extremamente positivo para áreas rurais e conta com financiamento adequado por parte do Ministério da Saúde. 
Em resumo, o documento apresenta-se como bastante limitado quanto às orientações teóricas e pouco desenvolvido em termos de propostas de atuação.

\subsection{Programa de comunicação social e controle nosólogico}

Quanto ao componente de Comunicação Social, dada à generalidade ainda maior de sua apresentação, pode-se considerar que apresenta como limitação importante o fato de estar voltado exclusivamente para o aspecto de transmissão de informação da MSS para a população. Essa transmissão, além disso, seria baseada principalmente em métodos bastante tradicionais e pouco eficazes para atuação junto a populações de baixa escolaridade: palestras, cartazes, correspondências. Além disso não apresenta, em nenhum momento, uma preocupação com atividade de Educação Ambiental. Aspecto esse que se revela extremamente negativo em um programa de Controle Ambiental.

Quanto ao programa de Saúde, o documento em estudo reconhece-se a necessidade de um levantamento mais detalhado do quadro epidemiológico local, ainda que não esboce diretriz mínima para esse levantamento.

Reconhece a fragilidade da estrutura de serviços e de financiamento e a necessidade de uma parceria entre as instituições locais e a MSS. No entanto, também, nesse item, não apresenta um esboço de proposta de como fazer isso, e encaminhar o problema levantado.

As poucas propostas esboçadas estão voltadas principalmente para os futuros funcionários do empreendimento, desconhecendo a comunidade local.

Esta posição é bastante inadequada não apenas do ponto de vista ético, mas também no que diz respeito à gestão e ao controle ambiental, visto que as questões de saúde-doença estão relacionadas ao ambiente (bio-psíquico e social) onde estará instalada a MSS. A exemplo do programa de Comunicação Social desenvolve pouca ou nenhuma preocupação com a Educação Ambiental.

Vale lembrar, ainda, que já existem propostas desenvolvidas no campo da saúde pública e do ambiente que poderiam estar sendo colocadas como alternativa de atuação. 


\subsection{Programa de monitoramento ambiental (sub-item: monitoramento de parâmetros socioeconômicos)}

Nesses itens nota-se uma limitação grave no tocante à elaboração de um cenário. Ainda que o documento tenha apresentado uma relação adequada dos dados secundários de caráter demográfico/ sanitário, que devem ser pesquisados para um diagnóstico da situação, no que diz respeito à caracterização econômica apresenta alguns aspectos problemáticos. Essa avaliação se deve ao fato de o documento valer-se basicamente de indicadores da economia formal para proceder à análise do movimento econômico do município em estudo, cujas breves características reveladas pelos documentos em análise, já permitem supor uma presença marcante da economia informal.

Este aspecto mencionado apresenta maior gravidade quando se considera que, para uma real contribuição ao município, a MSS está preocupada com projetos de geração de renda, de diversificação econômica, de busca de alternativas produtivas para a população locais e possíveis grupos remanescentes do empreendimento que devem abraçar todas as dimensões da economia local. Seria bastante prematuro estabelecer programas de intervenção social, de geração de renda, extremamente detalhados, sem a participação da população. No entanto, já numa fase de planejamento seria importante que fossem relacionadas propostas, estratégias e metodologias que já foram empregadas com êxito, cuja aplicação poderia ser pensada para Canaã dos Carajás. A esse respeito, o documento entretanto, limita-se a propor parceria com algumas entidades como a SEBRAE local, proposta essa adequada mas não suficiente.

\subsection{Programa do controle nosológico e do quadro geral de saúde}

O Programa de Controle Nosológico e do Quadro Geral de Saúde, parte integrante do Plano de Controle Ambiental - PCA, realizado para a MSS em Canaã dos Carajás, apresenta diversas falhas e superficialidade em vários aspectos.

O programa analisado não define estratégias concretas de controle nosológico, por não ter realizado ainda efetivo levantamento e caracterização do quadro geral de endemias, planejamento das ações relacionadas ao controle das grandes endemias, planejamento de programas específicos relacionados com outras doenças transmissíveis e levantamento das 
expectativas e dos principais anseios da comunidade, diálogo de fundamental importância para a obtenção de sucesso na implantação de qualquer projeto de intervenção.

Propõem ainda, como proposta de intervenção, que sejam efetuadas campanhas educativas de prevenção apenas quando identificados aumentos de endemias. Entretanto, mesmo com difícil coleta e obtenção de dados por subnotificação e não notificações de ocorrências, foram detectadas doenças graves como malária, hanseníase, leishmaniose, doenças de veiculação hídrica (parasitoses), dengue e febre amarela. Assim aparece necessário que, além das medidas propostas, haja planejamento de programas constantes de intervenção educacional em saúde, tanto para as endemias como para as outras doenças transmissíveis, incluindo as DST (doenças sexualmente transmissíveis), por serem de difícil controle, principalmente num contexto de rápido crescimento populacional.

Deve-se enfatizar ainda que no referido Programa não houve preocupação efetiva com a inexistência de saneamento básico na comunidade. As residências dispõem atualmente de precário sistema de fossas, inadequadamente dispostas muito próximas às cacimbas, de onde se obtém a água de consumo da população. Faz-se necessário, portanto, um estudo mais aprofundado dessa situação, já que foram detectadas doenças de veiculação hídrica, para obtenção de dados mais concretos sobre a provável contaminação da água e desenvolvimento de projetos específicos de estruturação do sistema de saneamento básico de Canaã dos Carajás.

O Programa é falho também no tocante á atenção à saúde bucal dos trabalhadores e da população. A cidade possui apenas um consultório odontológico e não há sequer citação de planos para melhoria neste tipo de atendimento à saúde, nem mesmo planejamento de ações educativas para prevenção das patologias bucais. Faz-se necessário um levantamento da situação da saúde bucal da população para a detecção de ocorrências como cáries, periodontopatias, cânceres, doenças infecciosas, transmissíveis e outras manifestações orais de doenças sistêmicas de acordo com a MSS (2000).

Conclui-se, portanto, que o Programa de Controle Nosológico e do Quadro Geral de Saúde, realizado pela empresa consultora, deve ser melhorado em diversos aspectos, devendo apresentar propostas concretas que colaborem para uma melhor atuação do setor de saúde, sendo de fundamental importância à definição detalhada efetiva do quadro nosológico atual e o diálogo com a comunidade, para que sejam detectadas também as expectativas e necessidades da população a ser diretamente afetadas pelos impactos prognosticados pelo EIA. 


\subsection{Programa de relocação (plano de relocação)}

A empresa realizou um levantamento cadastral, iniciado em 1998. O processo se deu em duas fases: negociação e compra dos estabelecimentos rurais da ADA e negociação e indenização dos imóveis domiciliares ocupados por posseiros e assentados sobre aquelas propriedades. Foram negociados 63 lotes rurais, com 34 proprietários, perfazendo um total de 3.283,60 ha na localidade de Sequeirinho, Sossego, Servidão e Baiano. Foram definidos critérios de negociação e o documento faz referência a este processo de negociação dos lotes localizados na ADA, e está em fase de conclusão; portanto a empresa já teria condições de informar ao órgão ambiental detalhe desse processo que se constitui um valioso subsídio para análise e avaliação do mesmo. O Programa não fornece elementos indicativos dos valores das indenizações, nem se essas indenizações estão de acordo com o preço de mercado. Na documentação analisada é mencionada uma avaliação formal feita por um perito, em relação à avaliação dos imóveis; no entanto o programa não traz esse documento, como comprovação.

O documento não se constitui em um plano ou programa, é um relatório parcial do processo de indenização dos lotes localizados na ADA.

No programa é citada a indenização paga aos imóveis de uso institucional como igrejas e escolas, que deveriam ser objetos de negociações específica com a Prefeitura Municipal de Canaã dos Carajás, a qual aplicou o recurso recebido na construção de outras unidades de ensino na sede do município e povoados próximos à área de abrangência do empreendimento. No entanto o mesmo documento não informa quantas escolas foram indenizadas na região do Sossego e Sequeirinho e quantas foram construídas com os recursos obtidos dessas indenizações e onde foram construídas.

\subsection{Programa de educação ambiental (pea)}

O Programa de Educação Ambiental que integra o Plano de Controle Ambiental, foi concebido e desenvolvido com base nas informações do EIA/RIMA, e do censo 2.000. Tem como objetivo contribuir para a conscientização ecológica, o aperfeiçoamento e o desenvolvimento do posicionamento crítico ambiental dos indivíduos inseridos no Projeto Sossego e na área de influência do mesmo, além de informar os moradores do município de Canaã dos Carajás, formando-lhes conceitos básicos e sensibilidades específicas, sobre os 
aspectos ambientais do empreendimento e as medidas mitigadoras e compensatórias a serem implantadas.

O PEA se embasará do modelo de desenvolvimento sustentável, que considera o desejo humano de melhoria da qualidade de vida, respeita o meio ambiente, e não produz exclusão social.

Pretendem usar as informações obtidas no EIA, como material didático para o desenvolvimento das atividades de educação ambiental, possibilitando a discussão da realidade do morador/trabalhador da Mineração Serra do Sossego.

O Programa terá uma interface, com os demais programas previstos neste plano de controle ambiental, em especial o Programa de Compensação Fauna e Flora, Programa de Compensação Inserção e Comunicação Social, Programa de Controle Nosólogico e do quadro geral de Saúde e o Programa de Prospecção, Salvamento e Preservação do Patrimônio Arqueológico, utilizando pedagogicamente seus dados, estudos, previsões, mapas, etc.

No documento ora analisado é especificado o que será executado a partir da instalação do projeto extrativista, e durante o (segundo e terceiro anos), serão incluídos os trabalhadores diretos da MSS. E na fase de operação serão realizadas avaliações periódicas, de três em três anos.

Os públicos alvos do programa são os moradores e os funcionários envolvidos na implantação e na operação da MSS, que considera as concepções educacionais da UNESCO para o séc. XXI, especificamente os quatros pilares sobre os quais a educação precisa assentar-se: $1^{\circ}$ Pilar: Apreender a APRENDER; Pilar: Apreender a FAZER; $3^{\circ}$ Pilar: Apreender a CONVIVER; $4^{\circ}$ Pilar: Apreender a SER. Constitui a soma das atividades anteriores.

O Programa apresenta outras premissas: simplicidade e objetividade; respeito às realidades locais, grupais e individuais: educacionais, psicológicas, econômicas e socioeconômicas, mensurabilidade resultados; interatividade.

No Programa é citado que será considerado esse marco referencial traduzindo-o para uma linguagem popular, buscando então o exercício da cidadania, a proteção do meio-ambiente e a participação para o desenvolvimento da cidade.

O conceito de educação ambiental que fundamenta esse programa reúne dois conceitos/valores e necessidade de preservar o ambiente e o exercício da cidadania. O PEA deverá contribuir para a mitigação da previsível dissociação social entre o trabalhador da MSS e o residente. O Programa está fundamentado na análise dessas informações por meio da divulgação de conceitos de desenvolvimento sustentável e dos dados levantados pelo EIA. 
O pilar metodológico básico ensejará a teoria construtiva, em que o conhecimento estará sendo efetivamente construído junto com os grupos alvos, via a estímulos do PEA, sem que haja a apresentação de "verdades prévias", priorizando-se assim a participação.

De acordo com o Programa, o mesmo deverá ser concebido através do enfoque transmulti e interdisciplinar da educação ambiental, onde os conceitos de desenvolvimento sustentável e preservação do meio ambiente serão tratados pelos conhecimentos básicos da língua portuguesa, das ciências físicas e biológicas (matemática, física, química, biologia e das ciências sociais, geografia, história, sociologia).

O Programa respeitará um fluxo de 04 etapas para os grupos alvos, compostos por: Preparação, Desenvolvimento, Avaliação e Correções e Adição de Novas Metas ou Prioridades. É prevista a implantação de um Conselho Ambiental na escola, formado por alunos, docentes e pais de alunos matriculados.

Os Resultados para o Programa de Educação Ambiental - PEA estão basicamente vinculados a dois itens: A implantação dos Programas do Plano de Controle Ambiental e a decorrente mitigação dos impactos do empreendimento no ambiente; e a melhoria da qualidade de vida da população de Canaã dos Carajás, determinada, principalmente, pela exposição a novas informações adoção de novos hábitos favoráveis à manutenção da saúde e prevenção de doenças.

A maior preocupação em relação a este programa, foi que ele se estruturou pelas informações contidas no EIA/RIMA do empreendimento, e utilizou-as como material didático, no entanto o levantamento realizado para o diagnóstico socioeconômico, foi extremamente deficiente nas informações levantadas.

O que se percebe no programa é que a empresa está preocupada apenas em ter como resultados a consolidação de sua imagem, e que segundo a mesma já é favorável, ao empreendimento.

Outro ponto que está nas entre linhas do Programa, é que a partir de sua implantação a empresa esperar receber em contrapartida a intensificação da aceitabilidade local das atividades da mineração e engajamento desta no PEA.

Esse fato leva-nos a pensar, que a empresa não está agindo corretamente com a comunidade, e os seus interesses estão muito acima do interesses coletivos, e que o programa é uma estratégia para conseguir seus objetivos. 
Percebe-se a ausência de um diagnóstico situacional que possa vir a ser utilizado para garantir o respeito às realidades locais e subsidiar futura mensuração de resultados planejados a alcançar.

Os grupos passarão pelas mesmas experiências e citam-se eventos pedagógicos elaboração de material, mas não se descreve como serão executados. Cita-se a cartilha, mas será que a comunidade-alvo quer fazer parte da elaboração.

O documento refere-se como produto, aceitação da imagem da empresa. Cita-se o desenvolvimento razoável dos projetos pedagógicos das instituições educacionais, mas não de que forma isso será alcançado.

Previsões de necessidades e quadro de recursos humanos. Cita-se a qualificação do coordenador do PEA, mas não está citada a exigência de ter experiência e vivência da prática em projetos, programas de características e especificidades regionais/locais.

O programa deveria propor resultados que identifiquem frentes alternativas de ocupação, trabalho e renda associativa-comunitária.

As propostas apresentadas foram teóricas e não práticas e que as ações educativas façam parte do trabalho produtivo e sejam construídas pelos atores sociais a que se destinam.

\subsection{Sistema de gestão ambiental (sga) e sistema geográfico de informações: plataforma para o sga.MSS}

O documento apresenta uma descrição da estrutura do Sistema de Gestão Ambiental da Mineração Serra do Sossego, a ser implantado nos municípios de Canaã dos Carajás e Parauapebas, Estado do Pará, na Província Mineral dos Carajás.

A MSS desenvolverá nos municípios mencionados as operações de lavra, beneficiamento de minério de cobre para a produção de 159.000 t/ano de concentrado, tendo o ouro como subproduto e o embarque através de ferrovias.

O Sistema de Gestão Ambiental a ser implantado pela MSS adotará, como concepção, a prática de Gestão Ambiental por todas as áreas operacionais e administrativas com responsabilidades claras e objetivas para a alta administração da empresa. Será desenvolvido desde a etapa de implantação do empreendimento e possuirá como apoio e assessoria uma área de extrema importância dentro de um contexto de gestão ambiental, que é a Área de Higiene Industrial, Segurança e Meio Ambiente (AHSM). 
Reunirá, em sua estrutura os requisitos, das normas internacionais - Série ISO 14000, NBR 14.000 e BS 7750 (British Standard) - os princípios, conhecimento e experiências ambientais dos controladores da MSS (CVRD - Mineração Andirá) bem como as avaliações, resultados e Programas Ambientais constantes do EIA/RIMA elaborado. Ao longo das etapas de implantação e de operação do empreendimento, estes programas sofrerão revisões e incorporarão os resultados da melhoria contínua preconizada pela norma ISO 14000.

O SGA é um programa de gestão voluntária e não implica necessariamente em certificação por entidades normatizadoras. Entretanto, a MSS terá como meta, na etapa de operação do empreendimento, a obtenção da certificação de conformidade com as normas ISO 14.000 .

Além de todos estes aspectos importantes, o SGA da MSS será desenvolvido de forma integrada ao Projeto de Gestão Integrada do Estado do Pará (PGAI/PA) e contará com uma "Comissão Permanente do SGA" cuja função maior é a de proporcionar uma integração entre a empresa e a comunidade com o conhecimento e a participação desta na gestão ambiental do empreendimento.

A "Comissão Permanente do SGA" da MSS constitui-se uma prática inovadora, cujos resultados só poderão ser avaliados durante sua fase de implantação, momento em que será possível qualificar e quantificar sua validade enquanto instrumento que garanta a crítica independente, única capaz de gerar mudanças substanciais no sistema de gestão ambiental da empresa com vista à obtenção de melhorias ambientais contínuas.

A Mineração Serra do Sossego optou pelo desenvolvimento e implantação do SGA, determinou adoção de algumas premissas que norteiam a metodologia de operação do SGA. São elas: Qualidade, Capacitação de RH, Linhas de Ação, Resultados, Legitimação e Sucesso, Integração funcional, Integração Institucional.

O Sistema de Gestão Ambiental e o Sistema de Qualidade, possuem peculiaridades principalmente do SGA em relação ao SQ, uma vez que ambos iniciam uma longa jornada de convivência nas organizações de maior porte. O Sistema de qualidade tem como um de seus principais objetivos responder as necessidades humanas expressas pelas expectativas de mercado em termos da qualidade de vida. Por sua vez, os SGA procuram atender a qualidade ambiental e, conseqüentemente, têm como "clientes", além do Homem, também representado pelos consumidores, concorrentes, fornecedores, funcionários, vizinhança, poder público e acionistas, o Ar, a Água, o Solo, a Fauna e a Flora, todos demandando igualmente, qualidade ambiental. 
O Sistema de Gestão Ambiental vai integrar ao Sistema Geográfico de Informações (SGI), que através dessas duas ferramentas em operação a MSS, pretende-se tornar parte de um grupo seleto de vanguarda na gestão empresarial .

O Sistema de Geográfico de informações trabalhará com informações atualizadas acerca da constituição física, biológica e socioeconômica e cultural da região diretamente impactada pelo projeto, bem como seus processos produtivos, os aspectos e efeitos esperados, as ações preventivas e corretivas, os resultados previstos e alcançados, além de todas as facilidades, procedimentos atualizados on-line, bancos de dados de registros ambientais e relatórios de desempenho ambiental constituintes do SGA.

Os Sistemas Geográficos de informação ou simplesmente SGI, são programas de computador (rotinas) agrupados em um sistema com a capacidade de gerenciar dados espaciais (qualquer informação referente à porção da superfície terrestre).

Avaliação do SGA será feita periodicamente (de 4 em 4 meses) quando é efetuada uma auditoria interna expedita do sistema, com auditores da própria MSS (auditores internos). Da mesma forma, anualmente é efetuada por uma auditoria de $2^{\mathrm{a}}$ parte, ou seja com consultores especializados

A avaliação dos SGI é realizada de maneira similar à dos SGA, ou seja, sistemática e permanente, durante a sua utilização pelos próprios usuários e gestores, de acordo com as necessidades específicas dos mesmos.

Tendo como base as características acima descritas o SGA apresentado a seguir mesmo foi baseado em normas e na legislação vigente; entretanto gostaríamos de apresentar as seguintes considerações:

1. A metodologia proposta pela MSS para o SGA permitirá que a empresa estruture um sistema eficaz que abrangerá todos os elementos e auxiliará o alcance dos seus objetivos ambientais e socioeconômicos; porém sabe-se que o sucesso de um sistema depende do comprometimento de todos os níveis hierárquicos de uma organização.

Esse comprometimento é atingido com o estabelecimento de um Programa de Gestão Ambiental efetivo e bastante abrangente. Esse programa não foi apresentado para completa avaliação, e apenas citado no SGA.

O Programa de Gestão Ambiental, foi estruturado através dos seguintes elementos: projetos ambientais, matrizes de resultados, cronologia e responsabilidades. Este programa deverá ser integrado ao plano estratégico da MSS, de forma a ganhar as condições mínimas adequadas para a sua efetividade. 
2. A integração do SGA da MSS ao Programa de Gestão Ambiental Integrada do Estado do Pará (PGAI/PA) do SGA e a uma Comissão Permanente de meio ambiente que atenda às expectativas e diretrizes da SECTAM, neste caso considerado o contexto socioeconômico da Região Norte do Brasil, especificamente o Estado do Pará, preocupa quanto à abrangência do escopo de atuação desta Comissão, podendo, além de outros problemas conferir dificuldades em sua operacionalização.

No geral o SGA apresenta-se em conformidade com o necessário padrão de excelência indispensável à implementação das séries ISO 14.000 e NBR 14.000, ressaltando-se, entretanto, que garantia deste sistema está irremediavelmente vinculada ao sucesso dos planos de controle ambiental da empresa.

\subsection{Plano de desenvolvimento sustentável para o município de Canaã dos Carajás (PDS) - programa de trabalho}

1 - Considerações Iniciais

O documento é um Programa de Trabalho que orientará a elaboração do Plano de Desenvolvimento Sustentável do Município de Canaã dos Carajás.

O Programa de trabalho tem como objetivo geral construir a base conceitual e operacional, requerida para a formulação do Plano de Desenvolvimento Sustentável do Município de Canaã dos Carajás.

Trata-se, em primeiro lugar, de identificar os problemas, possibilidades e alternativas de desenvolvimento para o Município de Canaã dos Carajás, no contexto de sua região de influência.

Em segundo lugar, propiciar as bases para a construção de cenários para o desenvolvimento da região do Plano, no contexto de atividades e ações que estruturem e dêem forma a cada um dos cenários concebidos, sempre conjugada com os programas dos planos de controle ambiental elaborados para o Projeto Sossego.

Deve ser feita a articulação com outras atividades e ações integrantes do plano com outras iniciativas programáticas previstas para a região.

Deve-se estabelecer mecanismos de articulação institucional, que possa multiplicar as possibilidades de desenvolvimento ensejadas pela exploração do complexo de atividades econômicas e sociais engendradas pela execução do projeto da Mineração Serra do Sossego.

Deve elaborar o Sistema de Gestão do Plano, coerente com as dificuldades e possibilidades oferecidas pela mineração e atividades que a partir dela possa, ser derivadas. 
Por fim, o Plano de Desenvolvimento Sustentável para o Município de Canaã dos Carajás deve ser concebido e executado de forma a poder servir como modelo de atuação para áreas de mineração da Amazônia. 


\section{Apêndices 4 Resumo dos programas de controle ambiental}

\subsection{Programa de compensação, inserção e comunicação social}

Este Programa objetiva integrar a MSS ao corpo social do Município de Canaã dos Carajás, possibilitando o seu desenvolvimento sustentável, com vistas à otimização do empreendimento e minimização dos efeitos perversos que porventura decorrerem. Preconiza a contextualização da chamada "agenda 21 local" inserida no lema "pensar globalmente, agir localmente".

O cronograma estima a execução do empreendimento no período de 15 meses assim distribuídos: a) Primeira etapa (3 meses) - identificação e sensibilização dos atores sociais, mediante levantamento de instituições públicas e privadas, estudos, programas e planos do setor, entrevistas com representantes institucionais e líderes locais, exposição do Programa e divulgação das ações; b) Segunda etapa (3 meses) - elaboração dos diagnósticos setoriais e integrados, contendo o planejamento das ações por setores, constituição de Comissão de Acompanhamento, elaboração do "Plano de Gestão e Desenvolvimento Territorial do Município de Canaã dos Carajás" (com parceria do SEBRAE), sob a coordenação da diretoria da MSS.; c) Terceira Etapa (3 meses) - Construindo a Agenda 21, via produção de documentos setoriais e integrados ao desenvolvimento econômico, conservação e gerenciamento dos recursos disponíveis e fortalecimento do papel dos governos locais e grupos sociais principais, participação de equipes técnicas e da Comissão Municipal de Desenvolvimento Sustentável e estabelecimento de um plano para o uso racional dos recursos advindos da Compensação Financeira pela Exploração Mineral (CFEM). Paralelamente, ocorrerão, no prazo de 6 meses, o acompanhamento e apoio à Comissão para sua consolidação.

A metodologia prevê a capacitação de componentes dos diversos grupos setoriais, utilizando abordagens e técnicas de Diagnósticos Rurais Participativos (DRP), cujos princípios básicos serão a realidade das comunidades e instituições locais, o planejamento e monitoramento das recomendações, a previsão das informações e a implementação em tempo hábil das ações. Técnicas participativas abrangerão ferramentas como a "tempestade de idéias", a construção da árvore problema - causa-efeito, o diagrama institucional e análise de Fortalezas, Oportunidades, Fraquezas e Ameaças (F.O. F.A).

Finalmente, o Programa inclui a execução de um Projeto de Comunicação Social, tendo em vista o melhoramento das relações entre a MSS e os diversos setores sociais. Como procedimentos metodológicos consta a apresentação do Projeto Sossego e suas propostas de 
redução e compensação dos impactos, mobilização e envolvimento da comunidade quanto aos assuntos ambientais e socieconômicos, suporte técnico à população nativa e à agregada em Canaã dos Carajás, além de campanha de esclarecimento ao quadro funcional da empresa dos riscos a que estarão passíveis de ocorrência.

\subsection{Programa do controle nosológico e do quadro geral de saúde}

Este Programa objetiva minimizar a sobrecarga na demanda por serviços de saúde, face à grande migração a ser atraída pelo empreendimento, em particular ao Município de Canaã dos Carajás.

O documento alerta sobre a inconsistência dos dados diagnosticados no EIA, como por exemplo, a ocorrência de doenças epidêmicas supera os registros de malária, hanseníase, dengue e febre amarela. Enfatiza que o quadro nosológico atual indica freqüências de diarréias, Doenças Sexualmente Transmissíveis (DST), e alta incidência de lesões uterinas, por deficiência de exames preventivos.

Aborda as ações a serem desenvolvidas pela Vigilância Epidemiológica no que diz respeito a doenças transmissíveis, não transmissíveis, acidentes, intoxicações, etc. Essas ações constituem-se de coleta e análise sistemáticas das informações, investigação epidemiológica dos riscos e adoção de medidas profiláticas e de controle. A recomendação é pela implantação de um sistema de notificação de doenças no ambulatório do Serviço de Medicina do Trabalho da empresa. O plano de ação, com a participação do Instituto Evandro Chagas e instituições

pertinentes, incluirá o controle das doenças detectadas, parceria com órgãos municipais e monitoramento das epidemias.

Campanhas educacionais e de esclarecimento estão previstas para o combate às grandes endemias. O Programa detalha ações a serem desenvolvidas contra a malária (eliminação de criadouros de anofelinos, proteção dos alojamentos e borrifação dos domicílios), a leishmaniose (testes laboratoriais e controle dos casos de doença), febre amarela e dengue (vacinação contra febre amarela e combate ao vetor). Receberão tratamento diferenciado a prevenção, e o combate a doenças transmissíveis como caxumba, coqueluche, difteria, rubéola, tuberculose, tétano, sarampo, cólera, febre tifóide, meningite, hepatite e hanseníase. Para isso será celebrado convênio com a SESPA. Ações educativas, por sua vez, serão veiculadas visando controlar as DST, exame de VDRL (pré-admissional e na rotina da empresa). Acidentes com animais peçonhentos merecerão capacitação dos profissionais de saúde e aplicação de soros. O Programa 
de Saúde Ocupacional manterá exames periódicos, prevenção e tratamento dos danos advindos do trabalho.

Menciona ainda o Programa que o seu gerenciamento contará com uma Coordenação de saúde e integração institucional (IEC, UFPA, FNS, SESPA, Secretarias Municipais de Saúde, serviços privados e filantrópicos). Em Canaã dos Carajás o sistema disporá de um hospital municipal, um posto de saúde na sede e quatro na zona rural. Em Parauapebas, o sistema de saúde já se encontra mais bem estruturado, inclusive com especialidades.

\subsection{Programa de relocação (plano de relocação)}

Este Programa de Relocação da População da Área Diretamente Afetada (ADA) esclarece que não ocorre de forma involuntária, mas por um processo de negociação com aquisição de terras e benfeitorias. Informa que o Município de Canaã de Carajás resultou da colonização dos então Centros de Desenvolvimento Regional - CEDERE II E III, e que no ano de 1984 foram assentadas mais de 1500 famílias, em lotes de 50 hectares, colonos sulistas e nordestinos, principalmente, que se dedicaram ao cultivo de cereais, fruteiras e pimenta-do-reino.

Atualmente a estrutura fundiária do Município contempla um montante de 1.036 estabelecimento cadastrados, predominando as pequenas unidades camponesas $(85 \%$ com menos de 50 ha) 7\% grandes unidades camponesas ( 50 ha a menos de 200 ha); $7 \%$ são fazendas com (mais de 200 ha até 5.000 ha) $1 \%$ são os latifúndios empresariais, (área acima de 5.000 ha). Esta situação aponta elevado nível de concentração fundiária, pois $74 \%$ do total da área dos estabelecimentos equivale à área ocupada por $4 \%$ dos estabelecimentos, que são as grandes fazendas e os latifúndios empresariais (com mais de 500 ha), enquanto $26 \%$ equivale à área da maioria dos estabelecimentos $(1 \mathrm{a}<500 \mathrm{ha})$ que representam $96 \%$ do tal dos estabelecimentos.

Verificou-se o fenômeno da migração para Redenção, Tucumã, São Félix do Xingu e as localidades de Tuerê e Vilinha.

É lícito assinalar que na Área Diretamente Afetada do Projeto Sossego permaneceu alguns estabelecimentos rurais e imóveis domiciliares ocupados por garimpeiros e assentados, daí a característica de negociação do Programa de Relocação. Presentemente, encontra-se em fase conclusiva o processo de indenização dos imóveis.

Oportuno enfatizar que dados estatísticos do Plano de Relocação apontam que já foram adquiridos pela Mineração Serra do Sossego cerca de 63 lotes rurais de 34 proprietários, totalizando uma área total de $3.283,60$ ha, outros 2.400 ha em breve serão concluídos. Eis alguns 
dos critérios de negociação: interesse do ocupante, proprietários, inquilinos e morador: documentação cartorial com encargo da Mineração Serra do Sossego, imóvel institucional com negociação específica com a Prefeitura Municipal e proprietários; avaliação dos imóveis por perito técnico. A grande maioria dos indenizados permaneceu temporariamente nos imóveis de origem, o que denota relacionamento amistoso entre empresa e comunidade.

\subsection{Programa de educação ambiental}

Este Programa de Educação Ambiental será implementado em consonância com o Programa de Compensação - Fauna e Flora, Programa de Compensação, Inserção e Comunicação Social, Programa de Controle Nosológico e do Quadro Geral de Saúde, e o Programa de Prospeç̧ão, Salvamento e Preservação do Patrimônio Arqueológico, ao longo de três anos.

O Programa preceitua os 4 pilares concebidos pela UNESCO, ou seja: $1^{\circ} \mathrm{Pilar}$ - aprender a APRENDER; $2^{\circ}$ Pilar - Aprender a FAZER; $3^{\circ}$ Pilar - aprender a CONVIVER, $4^{\circ}$ Pilar aprender a SER. Tem, ainda, como linhas de ação: simplicidade e objetividade; respeito às realidades locais, grupais e individuais; mensuralidade de resultados; e interatividade comunitária.

Por outro lado, as diretrizes do PEA estabelecem como marco referencial a consciência sobre o meio ambiente, conceituando a Educação Ambiental sob o enfoque valorativo da necessidade de preservar o ambiente e o exercício da cidadania. As temáticas dos conteúdos da Educação Ambiental alinham-se à conservação ambiental, e aos conceitos de desenvolvimento sustentável (conservação das águas, dos solos, da fauna e da flora, destinação do lixo, cidadania e mobilização social, conservação do patrimônio cultural e arqueológico), prevenção na saúde pública, e informações sobre o empreendimento, seus efeitos ambientais e o Programa de Educação Ambiental.

Os objetivos do Programa de Educação Ambiental propõem informar os munícipes de Canaã dos Carajás sobre os aspectos ambientais da atividade minerária, estimular a defesa da natureza e divulgar a legislação pertinente. $O$ processo operacional contemplará quatro grupos do público-alvo daquele Município, e pretende educar ambientalmente os residentes estudantes e os residentes não estudantes (04 a 18 anos), os adultos (acima de 18 anos) empregados e os não empregados no empreendimento. 
A metodologia será específica para cada grupo - alvo consoante as etapas da Preparação (pesquisa, prioridades, avaliação do material e preparação das lideranças), Desenvolvimento (sedução, implantação, geração de dados e acompanhamento), e Avaliação e adoção de novas prioridades, tendo como ferramentas à "Cartilhas Olho Aberto", "Mural", "Sala de Encontro", e a "Turma Ambiental". A meta do Programa de Educação Ambiental é atingir um total de 10.274 pessoas e implantar 66 "Conselhos Ambientais", entre outros propósitos, e a própria MSS reconhece que a obtenção dos resultados fundamenta-se na implantação dos programas do PCA e na melhoria da qualidade de vida da população do citado Município. O PEA prevê a contratação de recursos humanos especializados no setor.

\subsection{Programa de prospecção, salvamento e preservação do patrimônio arqueológico}

Este Programa envolve os seis sítios arqueológicos já identificados nas áreas de influência direta e indireta da MSS, sítios esses que se encontram inseridos no Cadastro de Sítios Arqueológicos PA -AT (Araguaia - Tocantins). A viabilização das pesquisas culminou com o convênio celebrado entre a MSS x FADESP x MPEG, tendo como principal objetivo à avaliação prévia dos impactos àqueles sítios, prospecção dos sítios selecionados, a preservação e salvamento, e estudo da cultura do material coletado nos sítios Sequeirinho, Sacramenta, Aeroporto, Domingo, Limite e Alvo Mata.

$\mathrm{O}$ documento centra suas informações considerando o contexto natural (características da geomorfologia, rede hidrográfica, os efeitos perversos do desmatamento acelerado e a presença de um solo preto não arqueológico, resultante de sucessivas queimadas), o contexto histórico (conflito pela invasão do branco no território anteriormente ocupados pelos índios Xikrin, extrativismo, pecuária, garimpo e mineração), o contexto arqueológico (área influenciada pelos povos Kaiapó - Xikrin, cuja cultura definiu a chamada Fase Itacaiúnas, filiada à Tradição Tupiguarani - 1300 anos de trajetória, podendo ainda ser encontrados vestígios remotos de 10.000 anos, presença de matéria prima lítica ao longo das margens do igarapé Sequeirinho), e o contexto atual (área bastante impactada antes da pesquisa geológica empreendida pela MSS, com os sítios submetidos às intempéries, queimadas anuais e garimpo).

A justificativa técnico-científica à implantação do Programa coaduna-se às evidências socioculturais pré-históricas. Os procedimentos metodológicos indicam a realização de exame "in loco" das áreas, o salvamento arqueológico mediante a seleção dos sítios a serem escavados (escavação completa quando o sítio não puder ser preservado ou parcial nos que poderão ser 
estudados no futuro). As amostras de cerâmico e lítico, de solo, de carvão e restos alimentares serão encaminhadas às instituições pertinentes (UFPA e MPEG), para análise. Os resultados serão divulgados mediante relatórios técnico-científicos, artigos científicos e materiais audiovisual.

O cronograma de execução prevê um prazo de três anos consecutivos: Ano I - Prospecção e salvamento dos sítios, Ano II - Elaboração de relatórios, e Ano III - Relatório final e livro, sendo que o material arqueológico ficará guardado na Reserva Técnica da Área de Arqueologia do Museu Paraense Emílio Goeldi, colocando-se, todavia, uma coleção tipo à disposição da empresa.

\subsection{Programa de paisagismo e cortina verde}

O objetivo deste programa é mitigar os efeitos de alteração da paisagem gerados pela implantação e operação do empreendimento, pelo surgimento de alamedas de árvores nativas ao longo das estradas internas e de acessos principais, de ambos os lados, entremeados por arbustivas com floração abundante. As superfícies administrativas terão arborização ao longo das vias e canteiros de ajardinamento. A maturidade desse sistema florístico será alcançada em dez anos.

As cortinas verdes constituirão de barreiras arbóreas e arbustivas densas, com altura acima de 5 metros, tendo como áreas prioritárias canteiro de obras, oficina de manutenção central, portaria, tanque de armazenamento de água, britagem primária, minérios oxidados estradas e pátios. As operações de implantação estabelecerão o preparo do terreno (subsolagem em faixas, correção da fertilidade, abertura e preparo das covas), plantio (escolha das espécies, qualidade das mudas, espaçamento), e adoção dos demais tratos culturais (replantio, irrigação, adubação, periódica, coroamento, cobertura morta em torno das mudas e controle de pragas).

Outrossim, o paisagismo visa integrar as áreas industriais e administrativas da MSS à paisagem regional, de acordo com a forma de utilização das benfeitoriais. $\mathrm{O}$ documento apresenta as concepções básicas do tratamento paisagístico das áreas, tais como: trevo da portaria (palmeira de macaúba - 650 mudas, camará - 3.000 mudas), estacionamento (árvores de copas frondosas, cercas-vivas arbustivas, gramados e arbustos floridos), e taludes internos (grama, árvores e arbustos ornamentais).

\subsection{Programa de reabilitação de áreas degradadas (PRAD)}


Objetiva recuperar as áreas degradadas pela implantação e operação do empreendimento, com vistas a assegurar o equilíbrio biológico e ecológico daqueles territórios.

A metodologia a ser aplicada estará em consonância com o tipo da área afetada. Nas obras rodoviárias e de rede de transmissão elétrica medidas de reabilitação/vegetação prevê, entre outras, taludes de corte e de aterro; na barragem de rejeito (drenagem e recobrimento com gramíneas e leguminosas); nas cavas Sequeirinho e Sossego (revegetação com taludes terrosos); macios de diques em terra (proteção contra a erosão, através de semeadura manual em sulcos rasos); pilhas de deposição de estéril norte e sul (revegetação com gramíneas e leguminosas no topo plano trafegável); unidades industriais e administrativas (tratamento paisagístico); canteiro de obras oficinas e instalações provisórias (plantio de mudas arbóreas); planta de recebimento, estocagem e embarque de concentrado em Parauapebas (grama ornamental e cortina arbórea).

Esse PRAD recomenda para plantio de espécies arbóreas nativas permanentes como o angico, araçá, cajá, cedro, copaíba, seringueira, ingá, ipê roxo, tucumã, jacarandá, jambo, sucupira e samaúma. Indicam o procedimento de hidrossemeadura às espécies capim gordura, braquiária e quicuio. Outras medidas são a descompactação de superfícies (destorroamento, nivelamento e arejamento do solo); implantação de cortina vegetal em torno das cavas (aroeira vermelha e caliandra); e cordão de enrocamento em torno das cavas.

\subsection{Programa de compensação ambiental: fauna e flora}

O programa objetiva promover ações de sustentabilidade de nichos ecológicos nas áreas atingidas pelo empreendimento da Mineração Serra do Sossego, por meio do retorno da vegetação arbórea, melhoramento do revestimento vegetal secundário, visando a evolução natural do ecossistema.

Inicialmente, está projetada a implantação de um subprograma de apoio à Prefeitura de Canaã dos Carajás para a instalação de viveiros de mudas, além do desenvolvimento de outro viveiro de mudas na própria MSS. Ambos terão instalações físicas administrativas e sala para palestras sobre Educação Ambiental.

No viveiro municipal (área superior a 17 hectares) a demanda de produção será de 200.000 mudas /ano, de espécies frutíferas, florestais e industriais; no da MSS a demanda reduzse para 55.000 mudas/ ano, de espécies para reflorestamento, reabilitação, e paisagismo.

A metodologia estabelece atividades como coleta e armazenamento de sementes, preparo anual de canteiros, semeadura, repicagem, irrigação, educação e pesquisa, além de outros 
aspectos operacionais (assistência técnica, controle fitossanitário, e mão-de-obra). Particularmente, no cronograma de revegetação, o viveiro da MSS, prevê a produção de 45.000 mudas para paisagismo, 682.500 mudas para reflorestamento e 650.000 mudas para reabilitação da área, totalizando 1,4 milhões de mudas ao longo dos 25 anos de vida útil do projeto.

É oportuno frisar que a MSS instalará uma área de Reserva Ecológica, com 304 ha, situada ao sul, próxima à usina de beneficiamento e da zona administrativa, aproveitando a existência de floresta primitiva da região, semelhante à da FLONACA, mata aquela riquíssima em biodiversidade. Entre as medidas de implantação e manutenção da futura Reserva Ecológica constam no Programa: cercamento nas frentes de penetração, colocação de placas informativas, inserção no programa de educação ambiental, implantação de uma área coberta interna para lazer e encontros educativos, instalação de torres de vigilância interna e nas bordas em locais estratégicos de observação, implantação de aceiros em frentes com potencial de incêndio, coleta de sementes no interior da reserva e monitoramento faunístico periódico no interior da reserva.

Outras medidas de compensação serão aplicadas, em forma de pesquisa para aperfeiçoamento dos métodos reabilitação e revegetação (variedades de espécies, testes de adubação e irrigação) e estímulo para recolonização de fauna nativa (mediante implantação de biótopos úmidos e de nichos secos).

\subsection{Programa de controle de drenagem e contenção de finos}

Este Programa contempla procedimentos de controle de drenagem e finos nas etapas de implantação e de operação, bem como manutenção do sistema de drenagem e controle, além de desassoreamento de drenagem no Morro do Sossego.

$\mathrm{Na}$ Etapa de Implantação do projeto o controle de drenagem nas obras de terraplenagem e de águas pluviais nas áreas industriais e nas obras de transposição e desvio de cursos d'água prevê a instalação de britagem primária, abertura de diques canais e construção de barragem de rejeitos; além de obras de contenção de sedimentos nas áreas da mina industriais e nas estradas (padrão DER).

Na Etapa de Operação estão previstos sistemas de controle de drenagem na mina, na área industrial, em pilhas e depósito de estéril, contenção de finos em depósitos de estéril, e na barragem de rejeitos. Para isso o sistema de controle, entre outros, recomenda a instalação de bacias para contenção dos finos, implantação de drenagem superficial, implantação de drenos de fundos e revegetação das superfícies. 
Nos procedimentos de manutenção dos sistemas de drenagem e controle dos finos serão utilizados retro-escavadeira, motoniveladora, limpeza anual no reservatório, correção nas estruturas do dique, e vistorias anuais nas plataformas, bueiros, canaletas, sarjetas etc.

A operação de desassoreamento de drenagens no Morro do Sossego e do Córrego Sequeirinho serão imprescindíveis, para a retirada de rejeitos de materiais de granulometrias variadas acumulados em razão da atividade garimpeira ali processada. Como medidas de recuperação dessas áreas o Programa estabelece a remoção dos rejeitos, implantação de drenos de fundo, restabelecimento dos canais de drenagem, regularização topográfica e revegetação.

\subsection{Programa de controle ambiental de obras de terraplenagem}

A empresa compromete-se a empregar medidas de controle aos impactos ambientais decorrentes da realização de obras de terraplenagem e pavimentação.

As principais ações de Programa implicam nos seguintes procedimentos:

1 - Política de Implantação do Empreendimento, como forma de atender as exigências do desenvolvimento sustentável, tendo como metodologia: a) fiscalização e acompanhamento de campo e das ações mitigadoras; b) coleta de dados e avaliação das potencialidades da região e sua exploração racional; c) utilização dos recursos humanos e fornecimento de serviços e materiais disponíveis no Município de Canaã dos Carajás, preferencialmente, bem como Parauapebas, Marabá e outros Municípios adjacentes.

O Programa estabelece, ainda, as obrigações contratuais da MSS alusivas à mão-de-obra, recrutamento e treinamento (mediante convênios com entidades pertinentes), serviços, saúde, educação, lazer e segurança.

2 - Fiscalização e Acompanhamento de Campo, objetivando comprometer as empreiteiras contratadas com os princípios voltados à defesa da natureza, consoante ações de minimização dos efeitos impactantes, recuperação das áreas degradadas e responsabilização pelos dados gerados.

3 - Articulação com outros Programas do PCA, tais como Programa de Controle de Decapeamento e Minimização de Desmates, Programa de Controle de Emissões Atmosféricas, Programa de Paisagismo e Cortinas Verdes, Programa de Controle de Drenagem e Contenção de Finos, Programa de Gerenciamento de Águas e Controle de Efluentes Líquidos, Programa de Gestão e Destinação Final de Resíduos Sólidos, Programa de Controle de Emergências Ambientais, Programa de Controle Nosológico e do Quadro Geral de Saúde, Programa de 
Prospeç̧ão e Salvamento do Patrimônio Arqueológico, Programa de Controle de Manutenção de Veículos e Equipamentos, Programa de Reabilitação de Áreas Degradadas, Programa de Compensação, Inserção e Comunicação Social e Programa de Monitoramento Ambiental.

\subsection{Programa de controle de manutenção de veículos e equipamentos}

O objetivo deste Programa é reduzir os riscos de acidentes, controlar emissões gasosas, ruídos e minimizar os riscos de contaminação com óleos e combustíveis. Classifica veículos e equipamentos utilizados nas operações de lavra, transporte de concentrado e na estação ferroviária em equipamentos móveis (caminhão pá carregadeira, motoniveladora, trator de pneu) e semimóveis (escavadeira, trator de esteira e perfuratriz rotativa).

O sistema de controle de manutenção controlará a emissão de gases, os procedimentos corretivos e preventivos de equipamentos e possíveis vazamentos de óleo.

O combustível utilizado na MSS é o óleo diesel, estimado em torno de $38.000 \mathrm{~m}^{3} / \mathrm{ano}$, fornecido pela Texaco do Brasil, cujas instalações de descarregamento e armazenamento serão em Parauapebas, sendo transportado em caminhões da empresa à área do Sossego. O sistema de drenagem prevê a condução para caixa separadora de óleo e água, sendo direcionado o efluente a um sumidouro.

A oficina de Manutenção Central, funcionará com 6 boxes com área total de $2.700 \mathrm{~m}^{2}$ equipado com parte rolante e capacidade de $70 \mathrm{t}$. Abrigará setores de Usinagem $\left(423 \mathrm{~m}^{2}\right)$, Oficina Elétrica $\left(148 \mathrm{~m}^{2}\right)$, Oficina Hidráulica e de Instrumentação $\left(95 \mathrm{~m}^{2}\right)$, e de Mecânica Industrial $\left(130 \mathrm{~m}^{2}\right)$, Calderaria e Solda $\left(785 \mathrm{~m}^{2}\right)$, Almoxarifado $\left(590 \mathrm{~m}^{2}\right)$, e área externa de $\left(5.600 \mathrm{~m}^{2}\right) \mathrm{e}$ Gerência de Manutenção e Administração $\left(714 \mathrm{~m}^{2}\right)$.

A empresa desenvolverá treinamento de mecânicos, motoristas e operadoras dos equipamentos e veículos, e encetará campanhas de conscientização da defesa ambiental.

Os anexos do Programa especificam os procedimentos operacionais para Controle de Emissão (fumaça de escapamentos) com Utilização de Escala RINGELMANN, as Normas NBR (avaliação do teor de fuligem) e NBR 6065 (grau de enegrecimento do gás de escapamento) e Procedimento Operacional de Manutenção de Equipamentos.

\subsection{Programa de controle de emissões atmosféricas}

Este Programa, discrimina os Padrões de Emissão e Imissão, as fontes de Emissão Atmosférica e os Sistemas de Controle de Emissões Atmosféricas. 
Cabe realçar que os padrões de emissão e imissão definidos na legislação - Resolução CONAMA 003/90, estabelecem os parâmetros de enquadramento dos efeitos a saúde humana com gravidade (padrão primário), de acordo com a média geométrica anual e concentração média de diversos períodos durante o ano, dos sólidos totais em suspensão, sólidos em suspensão (inalação), dióxido de enxofre, monóxido de carbono, ozônio e monóxido de nitrogênio.

Registra-se que as fontes de emissão atmosférica na Etapa de Implantação podem ser não estacionárias e fixas. As fontes de emissão não estacionárias derivam das movimentações de veículos pesados automotores e ação eólica sobre as pilhas gerando gases e material particulado. As fontes fixas decorrem de desmonte de rocha por explosivos, secador rotativo, peneiramento, transferência e manuseio de agregados, combustão de óleo, misturador de asfalto, aquecimento de cimento asfáltico e tanques de estocagem de óleos.

Na Etapa de Operação do empreendimento as emissões de fontes fixas deverão originarse, entre outros, da descarga de caminhões, manuseio de concentrado e ação eólica sobre pilhas e rejeitos, enquanto que as fontes não estacionárias procederão de partículas sólidas em suspensão ou poeira fugitiva e emissões gasosas provenientes dos motores diesel de máquinas, veículos e equipamentos.

Por sua vez, o sistema de controle dessas emissões na Etapa de Implantação obriga as empreiteiras instalarem filtro de manga e reciclagem do pó retido, sistema de exaustão para os silos de agregados quentes e fechamento dos silos de estocagem de massa asfástica; no controle de fontes não estacionárias utiliza-se à escala RINGELMANN, além do molhamento das pistas por aspersão de água com caminhão-pipa. Na Etapa de Operação o controle de fontes fixas será processado nas emissões provenientes de desmate de rocha, da ação eólica sobre pilhas de minério, da britagem primária, de manuseio e transporte de minério e estéril e de concentrado; além do que o controle em fontes não estacionárias será feito pelo molhamento das pistas em uso, mediante caminhão pipa.

\subsection{Programa de controle de decapeamento e minimização de desmates}

O Programa objetiva minimizar o impacto das áreas desmatadas e maximizar o aproveitamento do material lenhoso, material orgânico, sementes, propágulos e "topsoil" gerados nas operações de desmate e decapeamento (aqui concebido como a retirada e armazenamento da fina camada superficial do solo). 
O desmate ocorrerá nas áreas de mata alterada, mata enjuquirada e juquira. A empreiteira responsável preencherá uma "ficha de controle", anotando o local, tipo de vegetação, quantidade de vegetação, o agente responsável, a forma do desmate. Esta ficha valerá como "Termo de Compromisso" entre a MSS e a terceirizada.

O Programa impõe uma série de princípios básicos para minimização dos impactos e maximização do aproveitamento do material proveniente do desmate, tais como: autorização do órgão competente (licenciamento), mão-de-obra habilitada, proteção da fauna e medida alternativa à queimada. As operações de desmate serão de abertura de acessos de apoio (escoamento de madeira e de produtos vegetais, abastecimento de água e óleo), marcação de árvores comerciais ou úteis, desmate das árvores de valor comercial ou utilitário, desmate de madeira não comercial e da vegetação restante.

Foi também definido o destino final do material desmatado a saber: madeira de valor comercial ou útil (madeireiros locais, utilização própria, doação à Prefeitura Municipal de Canaã dos Carajás ou para entidades beneficientes), madeira não comercial (soterrada no local em valas rasas durante a terraplenagem) e material orgânico fino (aplicação de galhos finos, folhagens, gramíneas, sobre as áreas degradadas). Abstrai-se do Quadro 2.9 deste Programa um total de 951,45 ha das áreas a serem desmatadas no empreendimento (Cava Sossego; Cava Sequeirinho; Depósito de Estéril Sul; Depósito de Estéril Norte: Depósito de Minérios Marginais; Depósito de Minérios Oxidados; Área administrativa, Usina de Concentração e Acessos; e Barragem de Rejeitos).

O decapeamento do "topsoil" (nutrientes, microorganismos e germoplasma) produzirá material de boa qualidade à reabilitação de áreas degradadas onde será utilizado "Topsoil" em taludes. Esta atividade consistirá em uma operação mecanizada para retirada da camada superficial de até $30 \mathrm{~cm}$ do perfil natural do solo, produzindo cerca de $3.000 \mathrm{~m}^{3}$ de material por hectare, devendo ser armazenado em local não vegetado para posterior utilização em taludes a serem reabilitados.

\subsection{Programa de controle de ruídos, vibrações e detonação}

Este Programa, inicialmente, classifica os ruídos decorrentes da atividade de mineração mediante 3 (três) distâncias de apreensão: ruído na fonte (dezenas de metros, sem presença de obstáculos na proximidade); ruído em campo próximo (entre dezenas e poucas centenas de 
metros, com obstáculos naturais ou artificiais); e ruídos em campo distante (a centenas de metros da fonte, como fenômenos meteorológicos).

Acrescenta-se que o sistema de controle para as emissões de ruído em campo distante fundamenda-se na Norma NBR 10.151 da ABNT - Avaliação do Ruído em Áreas Habitadas. O nível básico determinado à área do Sossego e estação ferroviária de Parauapebas é de $45 \mathrm{~dB}(\mathrm{~A})$, corrigido para zona de hospitais, residencial urbana, centro da cidade e área industrial. No entanto, é aplicado fator de correção ao nível critério de ruído para as vizinhanças do empreendimento em Canaã dos Carajás sendo $70 \mathrm{~dB}(\mathrm{~A})$ e $65 \mathrm{~dB}(\mathrm{~A})$ nos períodos diurno e noturno, respectivamente. Interessante observar que o nível sonoro do ruído ao ultrapassar o nível critério a comunidade assume conduta de queixas esporádicas e generalizadas solicitando e exigindo providências por parte das autoridades competentes.

Quanto às vibrações o documento informa as diversas classes de danos decorrentes: aparecimento de danos (descascamento de pintura e aumento de fissuras); danos leves (fissuras superficiais sem atingir as estruturas); e danos significativos (enfraquecimento de estruturas com fissuras abertas). A ABNT impõe como suportável o limite de velocidade de $15 \mathrm{~mm} / \mathrm{s}^{2}$ de vibração para construções residenciais e industriais, média essa que a Mineração Serra do Sossego compromete-se a manter nos níveis de vibração na área de entorno do Sossego.

Assevera o Programa que na Etapa de Implantação do empreendimento os ruídos terão como fonte de emissão o funcionamento de equipamentos móveis e semimóveis acionados por motor diesel utilizados em obras civis; enquanto que operações de desmonte de rocha serão responsáveis pelas fontes de emissão de vibrações. Por outro lado, na etapa de operação os ruídos procederão, principalmente, de detonaç̃os com explosivos dentro das cavas, equipamentos de britagem, funcionamento de bombas elétricas e trânsito de caminhões; já as vibrações, contudo, decorrerão de desmonte de rocha.

Finalmente, o documento sugere medidas de controle de emissão de ruído como a utilização de equipamentos convencionais de construção civil, manutenção preventiva e outros. O controle de vibrações indica a observância do limite de velocidade, limite de carga explosiva e utilização de sismógrafo para medição da velocidade das partículas resultantes das detonações. 


\subsection{Programa de gerenciamento de águas e controle de efluentes líquidos}

O documento descreve as ações concernentes à captação, tratamento e racionalização do uso das águas a serem utilizadas nas diversas etapas do empreendimento, tendo por escopo o aproveitamento de um produto qualitativo e quantitativo.

Para atingir esse objetivo foram concebidos projetos de engenharia, contemplando sistemas de suprimento de água (origem, quantidade e características físico-químicas), sistemas de recirculação e aproveitamento de água (características técnicas) e sistemas de tratamento e disposição de águas residuárias (controle efluente sanitário e de efluentes industriais).

A demanda de $550 \mathrm{~m}^{3} / \mathrm{h}$ de suprimento de água prevista à operacionalização do projeto será provida pelo rio Parauapebas, em operação contínua 24 horas/dia e 365 dias/ano. Para viabilizar os procedimentos de captação, tratamento e distribuição de água, o PCA prevê a construção de adutora de aço com extensão de $5,7 \mathrm{Km}$, e de um reservatório com capacidade de $2.380 \mathrm{~m}^{3}$.

Ademais o programa indica o fornecimento de água bruta para a Usina de Concentração: Sistemas de selagem de bombas, de abatimento de pó e de umidificação da pilha da estocagem de concentrado; alimentação da ETA, pontos de serviços, e rede de água de incêndio. A água potável será destinada ao uso humano em geral.

Vale acrescentar que o documento em análise contém diversas tabelas demonstrativas, com detalhamento técnico das pesquisas encetadas pela empresa responsável, a qual anexou mapas de projetos da ETA, dos Sistemas de Fossa, Filtro e Vala de absorção, da Drenagem Oleosa da Oficina Central dos Sistemas Separadores, Água/Óleo, dos Sistemas de Tratamento de Efluentes do Laboratório e da Filtração, bem como do Desenho de Pontos de Amostragem e subbacias de drenagem.

\subsection{Programa de gestão e destinação final de resíduos sólidos}

$\mathrm{O}$ documento, detalha em dois quadros estimativos, correspondentes às Etapas de Implantação e de Operação do Projeto, respectivamente, os tipos de resíduos sólidos, a descrição do material, a quantidade provável gerada por ano, o enquadramento classificatório, quais os passíveis de reciclagem e de reutilização e a destinação ao próprio fornedor ou aterro. A previsão é de que na fase de operação serão produzidos cerca de 50 milhões de toneladas de resíduos sólidos/ano. 
O Capítulo "Coleta Seletiva de Resíduos" determina os procedimentos a serem adotados na separação dos componentes, manuseio e acondicionamento dos resíduos, consoante o conceito dos 4 R's (Redução, Reutilização, Reciclagem e Recuperação).

A destinação final dos resíduos prevê distribuí-los em aterros, depósitos, sistemas de compostagem, mediante a classificação em Resíduos Perigosos não Inertes e Inertes. Os locais deverão ser de fácil acesso, topografia favorável, afastados de cursos d'água, com lençol freático profundo, afastado de tráfego público e sem nenhum uso atual.

O Plano Operacional estabelece etapas como limpeza do sítio, construção de cerca de proteção, instalação de portão de acesso e de placa de aviso, deposição e compactação dos resíduos, proteção ambiental e controle contra poeira, gases, e instalação de poços de monitoramento da qualidade de águas subterrâneas.

São considerados Resíduos Perigosos, entre outros: baterias, cartuchos, embalagens de produtos de limpeza, lâmpadas e material hospitalar. Como Resíduos não Inertes temos bombonas plásticas, papéis, isopor, sucatas ferrosas e tambores. Classificam-se como Resíduos Inertes os materiais de entulho, madeiras e pneus.

\subsection{Programa de controle de emergências ambientais I: plano de emergência}

O chamado Plano de Emergência sintetiza em dois volumes as medidas preventivas e controladoras de acidentes na manipulação de insumos e produtos perigosos e eventuais danos ambientais.

Na primeira parte o plano estabelece os cuidados com vistas à integridade físico-orgânica do 666 funcionários que desempenharão cargos e funções nos setores Produção, Manutenção e Administração da MSS, grande parte sujeitos ao manuseio de explosivos, gases, líquidos e sólidos inflamáveis, substâncias tóxicas e corrosivas.

A metodologia para análise de risco se fundamenta na norma BS 8800 do "British Standard" integrada à ISO 14.000, tendo como passos: avaliação qualitativa dos riscos, eliminação/minimização dos riscos e revisão destas etapas anteriores. O documento conceitua os termos Perigo, Risco e Segurança; classifica os efeitos dos acidentes (desprezível, marginal, crítica e catastrófica); aplica modelo de ficha de Avaliação Preliminar de Risco (APR); e aponta as recomendações à prevenção e controle de acidentes.

O Plano de Emergência discrimina os Recursos de Apoio (sistema de hidrantes, sistema de iluminação, abastecimento d'água, instalações de comunicação, equipamentos de socorro, centro médico, vigilância e suporte logístico). Deve-se enfatizar os procedimentos de 
emergência a serem adotados em casos de acidentes como incêndio, explosão, vazamento, atropelamento, derramamento de material e rompimento de diques constantes no plano. Detalha, ainda, a estrutura para atendimento emergencial, concernente às responsabilidades dos encarregados pela proteção e os procedimentos adequados para sanar os sinistros. Define, finalmente, as ações de manutenção e atualização dos sistemas de atendimento a emergências (revisão, treinamento e simulações).

O documento integra, como anexos, desenhos que visualizem o layout das instalações e complexo de estocagem de matérias-primas, insumos e combustíveis do Projeto Sossego.

\subsection{Programa de controle de emergências ambientais II: plano de emergência}

Trata este volume da complementação do Plano de Emergência da MSS. É composto por 19 anexos, alusivos à etapa de implantação (anexos 1 a 5) e à etapa de operação (anexos 6 a 19) do Projeto Sossego.

Revela-se oportuno frisar que todas estas composições relatam informes componentes da APR (Avaliação Preliminar de Risco), contendo dados indicativos a respeito de perigo do risco, evento e causa condicionantes da falha cometida, os graus de gravidade e probabilidade, e as medidas de prevenção e minimização, correção e emergências para minorar/eliminar os dados resultantes dos acidentes.

Na Etapa de Implantação tais riscos são passíveis de ocorrência em localizações pontuais como nas obras de terraplenagem das instalações e abertura de estradas, na estocagem de óleo diesel, no posto de abastecimento provisório da obra, na fábrica de explosivos e nas oficinas de manutenção. Observa-se que a utilização de equipamentos apropriados, com a devida manutenção mecânica e operacional são fatores que contribuirão para maior segurança no trabalho.

Entrementes, na Etapa de Operação do projeto as probabilidades dos riscos sinalizam a imperiosidade de aprimoramento nas medidas de prevenção e minimização, de sorte que diminuam, sensivelmente, os perigos, as falhas e os efeitos dos riscos. O documento, ora analisado, enumera que os pontos de vulnerabilidade concentram-se na estrada de interligação Projeto Sossego/Estação de Embarque e localidades, na estocagem de óleo diesel, no ponto de abastecimento de caminhões, no depósito de concentrado do beneficiamento e da estação de embarque, na fábrica de explosivos, nos diques de obtenção de finos, no depósito de estéril norte dreno de desvio, na barragem de rejeitos, no sistema de drenagem da cava, na unidade de 
concentração, na oficina de manutenção central, no depósito de concentrado, no restaurante e na reserva florestal.

Por fim, assume caráter relevante o silêncio do Plano sobre a composição elementar de uma Comissão Interna de Prevenção de Acidentes (CIPA), conforme impõe a legislação trabalhista vigente no ordenamento jurídico do País.

\subsection{Plano de controle ambiental: sistema de gestão ambiental}

O Sistema de Gestão Ambiental se enquadra nos conceitos básicos da NBR 14.000 definidos pela ABNT como "estrutura organizacional, responsabilidades, práticas, procedimentos, processos e recursos para implementação da gestão ambiental".

Deve-se frisar que o documento divulga os diagramas esquemáticos dos estágios de implantação e manutenção do Sistema de Gestão Ambiental segundo as normas BS 7750 e ISO 14.000, que em linhas gerais, constitui-se de passos como: estabelecimento da política ambiental, planejamento do SGA, implantação e manutenção do SGA propriamente dito, verificação e ação corretiva, e análise crítica pela administração.

Informa o documento ora enfocado que o Sistema de Gestão Ambiental da Mineração Serra do Sossego foi concebido mediante as normas ISO e ABNT, fundamentado no EIA do empreendimento. A concretização da Gestão Ambiental da MSS terá como bases: política de meio ambiente da MSS, objetivos e metas, organização empresarial e pessoal especializado, plano de controle Ambiental, manual de procedimentos e comissão permanente do SGA. É conveniente destacar que o Sistema de Gestão Ambiental da MSS encontra-se em consonância com os princípios estabelecidos pela SECTAM na publicação "Guia Ambiental do Estado do Pará", dentre os quais integram avaliação dos impactos ambientais, audiências públicas, educação ambiental, territórios protegidos, licenciamento ambiental e zoneamento econômico ecológico.

O Sistema de Gestão Ambiental para sua implantação e manutenção tem como estrutura organizacional à direção máxima da empresa e uma Comissão permanente, a qual avaliará o desempenho ambiental da Mineração Serra do Sossego com o apoio da Área de Meio Ambiente, Higiene e Segurança do Trabalho da própria empresa.

A Mineração Serra do Sossego definiu a sua política ambiental fundada, principalmente nos pressupostos de desenvolvimento de suas atividades, produtos e serviços contemplando a sustentabilidade dos recursos naturais, tendo como elementos essenciais a sua Missão 
Ambiental, Diretrizes Ambientais Estratégicas, Fatores-Chave de Sucesso Ambientais e Integração do Sistema de Gestão Ambiental com os demais sistemas gerenciais da MSS.

Vale acrescentar que os Programas de Controle Ambiental, cujos objetivos e metas integram o Sistema de Gestão Ambiental da MSS, foram objeto de elaboração específica os quais são resumidos no presente trabalho.

O Sistema de Gestão Ambiental, ainda, elaborará um manual que indicará a política ambiental, programas, objetivos e metas, legislação e normatização e outros procedimentos nas Etapas de Implantação e de Operação. Entretanto, todas as informações concernentes ao Sistema de Gestão Ambiental constituirão um banco de dados, cujo acesso será estabelecido pela administração da MSS.

O Plano de Auditoria Ambiental da Mineração Serra do Sossego objetiva avaliar a estrutura organizacional, os procedimentos administrativos e operacionais, as áreas de trabalho, operação e processos e as extraordinárias (obedecendo a protocolos específicos).

A revisão será semestral durante a Implantação, e anual na Etapa de Operação.

\subsection{Sistema de gestão ambiental da mss e sistema geográfico de informações: plataforma para o sga/mss}

É extremamente estranho como é abordado no SGA da MSS, o que seria o objeto da gestão ambiental na visão da empresa. Segundo o documento o objeto da gestão ambiental é a otimização dos processos da transformação de um sistema ecológico, primitivo ou não, realizado por uma atividade antrópica. Esta é uma conceituação completamente fora do que prescreve a ABNT.

$\mathrm{Na}$ realidade quando se fala em gestão está-se referindo à eficiência e eficácia organizacionais, aumento de produtividade, redução de custos, economia de recursos e insumos, transparência perante terceiros, sucesso, limpeza de processos e garantia de ambiente controlado e conservado, simultaneamente.

Essa gestão requer aplicação de mecanismos para planejar, implantar e manter ações, registrar as atividades e seus resultados atingidos, documentar, monitorar e controlar além de discutir e aprimorar os processos e resultados. Sistema de Gestão Ambiental é conceituado como "o conjunto sistematizado de políticas, diretrizes, objetivos, metas, programas, projetos, ações sistemáticas de registro e documentação para cumprir com as finalidades de gestão empresarial, garantindo a qualidade ambiental de seu desempenho". 
Nesse sentido, os níveis da Gestão Ambiental envolvem as Gestões de Processos, de Resultados, da Sustentabilidade e do Sistema de Gestão Ambiental. A Mineração Serra do Sossego tem por fim, através do Sistema de Gestão Ambiental, auferir benefícios de ordem político-institucional, técnico gerencial, econômico-financeira, social e ambiental.

Cabe ressaltar que a metodologia operacional do Sistema de Gestão Ambiental da MSS obedecerá como premissas básicas a Qualidade e Capacitação de Recursos Humanos, as Linhas de Ação, os Resultados, a Legitimação e Sucesso e a Integração Funcional e Institucional. Como princípios de viabilização do Sistema de Gestão Ambiental serão mencionados a Política Ambiental; Planejamento; Implementação e Operação; Análise, Avaliação e Ações; Inspeção e Aperfeiçoamento. A cada um desses princípios correspondem atividades de desenvolvimento, reuniões, inspeções, desenvolvimento de procedimentos e capacitação de recursos humanos.

Convém assinalar que a implantação do Sistema de Gestão Ambiental decorrerá de forma sistemática, gradativa e permanente, em contínua automatização, o que permite economizar tempo e recursos. Serão feitas avaliações com base nos resultados, através de auditoria interna quadrimensal, sobre cada um de seus princípios, requisitos e elementos.

Deve-se, também, enfatizar que os Sistemas Geográficos de Informações (SGI) e Banco de Metadados são considerados ferramentas de geoprocessamento da gestão ambiental da MSS. Esses SGI são desenvolvidos e implementados, por intermédio das etapas de Organização de dados, Visualização, Relação espacial, Combinação, Análise e Predição, inseridos em um Sistema de Documentação, sendo sua avaliação similar à do SGA (sistemática e permanente).

O documento aponta como estrutura organizacional para o SGA e o SGI a composição de Comitê de Gestão Ambiental (CGA), Ouvidoria Ambiental (OUA) e Centro de Excelência para a Gestão Ambiental (CEA) da empresa.

\subsection{Plano de desenvolvimento sustentável (pds) do município de Canaã dos Carajás: programa de trabalho}

Este plano serve de orientação ou roteiro à elaboração do efetivo Programa de Desenvolvimento Sustentável de Canaã dos Carajás. Esse Programa resultará de contribuições de setores públicos, organizações sociais, ONG's e empresas particulares, para produção de um texto consoante com os Programas de Controle Ambiental da MSS.

Na introdução mencionou-se dados demográficos, processos de ocupação e performance econômica do Estado do Pará, enfocando as providências do Governo Estadual para alavancar o 
progresso regional. Enfatiza as grandes transformações socieconômico-ambientais que se sucederão no Município de Canaã dos Carajás com a implantação da MSS.

Aborda no Capítulo "Contextos dos Trabalhos", detalhes informativos sobre a MSS; estudos de pré-viabilidade técnico-econômicos e ambientais originando o Plano de Aproveitamento Econômico (PAE); a potencialidade, metas, operacionalização, custos e receitas do empreendimento; a demografia da área objeto; e as providências de minimização e compensação dos impactos impostos pela atividade da MSS.

Adiante é discutido que a garantia da sustentabilidade do desenvolvimento do Município implica na adoção de políticas de manutenção da biodiversidade e consoante às dimensões ambiental (ecológica), tecnológica, econômica (estrutura produtiva), sociocultural (desenvolvimento humano) e política-institucional. Para alcançar tal desiderato o Programa define uma série de objetivos, dentre os quais a identificação dos problemas, possibilidades e alternativas de desenvolvimento de Canaã dos Carajás e articulação das especificidades do Plano com as demais ações previstas para a região.

A concepção do Plano obedecerá aos ditames da chamada metodologia participativa (enfoque técnico e envolvimento da população local), tendo como foco central o marco conceitual do desenvolvimento sustentável, com base em experiências recentes com o Projeto Áridas, executado no Nordeste do País (que obteve a cooperação técnica do Instituto Interamericano Ciências Agrárias - IICA). O Plano de Canaã dos Carajás prevê desenvolvimento de setores ou "Clusters" e das "cadeias produtivas". A metodologia ensejará, ainda, a sistematização do acervo de dados e informações disponíveis, consulta à sociedade, participação institucional, definição das opções estratégicas e o detalhamento do Plano. A MSS pretende desenvolver o Programa em 6 meses, contendo as discussões preliminares, formação do diagnóstico, estratégias e diretrizes gerais, ações programáticas, sistema de gestão e conclusão dos trabalhos.

A título de ilustração o documento esclarece que os trabalhos técnicos do Plano serão processados pela Empresa Contemat Engenharia e Geotecnia Ltda, de cujos esforços redundarão um Relatório Parcial (Resultado do Processo de Consulta à Sociedade); posteriormente, um $2^{\circ}$ Relatório Parcial (Diagnóstico, Estratégia e Diretrizes Gerais), correspondente a Relatório Geral em Versão Preliminar; e, finalmente a um Relatório Geral, que na verdade será o Relatório Geral em Versão Final. 


\subsection{Programa de fechamento}

Preconiza as medidas indispensáveis à reabilitação da área afetada após a conclusão da vida útil do empreendimento, consoante o equilíbrio físico, químico e biológico, de forma a não comprometer os usos futuros concebidos para depois do fechamento da mina.

O Programa estabelece revisão com sazonalidade trienal mediante a observância do planejamento de lavra e de operação, dos estudos hidrogeológicos e ao detalhamento do plano de fechamento nas cavas do Sequeirinho e do Sossego. Determina, também, a recomposição do cenário paisagístico, avaliação da vazão e da qualidade das águas nos níveis originais e a preservação da qualidade do ar compatível com as normas e padrões ambientais. Este documento assevera profundas transformações no panorama socioeconômico do Município de Canaã dos Carajás, como efeitos benéficos da elevação da arrecadação, geração de empregos e elevação da renda per capita. Ressalta ainda, o Plano de Revegetação nas áreas degradadas as ações de repovoamento faunístico, visando o restabelecimento, se possível, da megadiversidade característica da região.

Como estratégia de viabilizar este Plano de Fechamento comprometido com as premissas do Desenvolvimento Sustentável, foram elaborados diversos Sub-programas, tais como: Subprograma de apoio à diversificação econômica do Município; de comunicação social durante o fechamento; de aproveitamento da infra-estrutura; de demolição e desmontagem; de descontaminação; de fechamento e estabilização das áreas de mina e depósitos de estéril e rejeito; de fechamento dos depósitos controlados e de resíduos; de reabilitação de áreas degradadas; e finalmente, o Subprograma de monitoramento da eficiência da reabilitação no pósfechamento.

É conveniente realçar que cada Sub-programa apresenta detalhamento de sua operacionalização, com o objetivo a minimizar os impactos do empreendimento. A visualização dos procedimentos com vistas ao pleno êxito do Fechamento do Projeto Sossego, consta no Desenho de Referência, anexo ao documento, que evidencia a descrição das revisões sazonais do plano.

\subsection{Programa de monitoramento}

Avalia sistematicamente as modalidades de monitoramento a seguir. 
a) Emissões atmosféricas e qualidade do ar, particularmente nas Etapas de préImplantação, Implantação e Operação da MSS, com base nos locais de coleta de amostras, equipamentos utilizados e freqüência de coleta;

b) Efluentes líquidos e qualidade das águas, através da análise da qualidade das águas superficiais e subterrâneas, consoante às diretrizes exigíveis pela ABNT - Normas NBR 9897 e NBR 9898;

c) Radionuclídeos, presentes pelas emanações de gás radônio, poeira e rejeito de concentração. (Como principais medidas de minimização são propostas a ventilação natural ou forçada, velocidade reduzida dos veículos e cobertura vegetal). O Programa contém planta com pontos de amostragem e medidas, bem como Diagrama de blocos do processo com a identificação dos pontos de controle;

d) Vazões dos cursos d'água, (O Programa prevê instalações de medições fluviométricas em 2 pontos no rio Sossego e 3 no rio Parauapebas);

e) Ruídos e vibrações, pelo acompanhamento sistemático das ondas sonoras e de vibrações, provocados por máquinas, equipamentos e detonações (uso de sismógrafos padronizados). O limite tolerável será de 10 DB (A), mediante as normas NBR 10152;

f) Registro de ocorrência de acidentes (exceto acidentes de trabalho). Esse registro conterá informações precisas, entre outras, sobre local/hora/data/causa/descrição do evento, obedecendo a um modelo de ficha de notificação de incidentes;

g) Parâmetros meteorológicos: a estação a ser implantada possibilitará o estabelecimento de metodologia de amostragem do ar e interpretação dos dados. São componentes principais da estação: instrumentos como o nemômetro, potenciômetro, pluviômetro, medição da umidade relativa do ar e microprocessador;

h) Parâmetros biológicos, tanto na fauna terrestre e aquática (mastofauna - mamíferos não voadores; avifauna; herpetofauna e ictiofauna), como no revestimento florístico e de reabilitação;

i) Nosológico, visando proteger a população contra as endemias da região e outras doenças transmissíveis;

j) Parâmetros socioeconômicos, pela da análise de indicadores de nível de renda, de emprego e da qualidade de vida (saneamento básico, saúde, educação e segurança) no Município de Canaã dos Carajás;

k) Arqueológico, em convênio com o MPEG. 


\section{APÊNDICES 5. Questionário}

Identificação do entrevistado

Data: / / Local/Estado:

Nome:

Gênero: ( )M ( )F Estado Civil

Idade: Formação: Naturalidade Nível: Graduação ( ) Mestrado ( ) Doutorado ( )

Profissão:

E- mail:

Contato:

Ocupação (ões) Principal (is):

\section{QUESTIONÁRIO}

1. Normalmente, nos EIA que tem participado, os Termos de Referência:

( ) são documentos muito genéricos

( ) são documentos muito precisos

( ) nenhuma das anteriores

( ) não tenho informações

( ) são documentos pouco objetivos

( ) são documentos muito objetivos

( ) nenhuma das anteriores

( ) não tenho informações

( ) são documentos que deveriam ser anexados aos EIA

( ) são documentos que não deveriam ser anexados aos EIA

( ) nenhuma das anteriores

( ) não tenho informações

( ) são documentos que necessitam de instrumentos normativos complementares à legislação federal

( ) não são documentos que necessitam de instrumentos normativos complementares à legislação federal

( ) nenhuma das anteriores

( ) não tenho informações

2. Quanto aos Recursos Financeiros destinados à elaboração dos EIA/RIMA, normalmente:

( ) o principal critério das licitações (maior peso) é a qualificação da equipe técnica

( ) o principal critério das licitações é o menor preço dos serviços

( ) nenhuma das anteriores

( ) não tenho informações

( ) tem sido direcionado para a escolha das empresas mais qualificadas, mesmo com custos maiores 
( ) tem sido direcionado para a escolha de empresas pouco qualificadas, que apresentam os menores custos

( ) nenhuma das anteriores

( ) não tenho informações

( ) tem proporcionado estudos detalhados e de grande profundidade

( ) tem gerado estudos fracos, muito simplificados e pouco seguros

( ) nenhuma das anteriores

( ) não tenho informações

( ) tem provocado cronogramas apertados, com pouco tempo para os estudos de campo

( ) tem provocado cronogramas amplos, oferecendo tempo suficiente para detalhados estudos de campo

( ) nenhuma das anteriores

( ) não tenho informações

3. Quanto aos Prazos para execução do EIA, o tempo disponível:

( ) tem sido suficiente em decorrência da complexidade dos estudos nas diversas regiões do Brasil

( ) não tem sido suficiente em decorrência da complexidade dos estudos nas diversas regiões do Brasil

( ) nenhuma das anteriores

( ) não tenho informações

( ) não atende às dimensões dos empreendimentos e tem contribuído para fragilidade dos estudos

( ) atende às dimensões dos empreendimentos e tem contribuído para a efetividade dos estudos

( ) nenhuma das anteriores

( ) não tenho informações

4. Os EIA's quanto à sazonalidade dos estudos em ambientes complexos e com estação definidas, normalmente:

( ) são exigidos estudos respeitando-se a sazonalidade

( ) os estudos são realizados em apenas uma época do ano

( ) nenhuma das anteriores

( ) não tenho informações

5. Quando na Área de Influência Direta dos projetos, ocorrem Unidades de Conservação ou Reservas Indígenas:

( ) são realizados estudos particularizados para estas áreas protegidas

( ) não são realizados estudos particularizados para estas áreas protegidas

( ) nenhuma das anteriores

( ) não tenho informações

6. Nos EIA normalmente a participação da sociedade civil em Audiências Públicas:

( ) o RIMA tem propiciado a participação efetiva do público nas discussões sobre o empreendimento 
( ) o RIMA não tem propiciado a participação efetiva do público nas discussões sobre o empreendimento

( ) nenhuma das anteriores

( ) não tenho informações

( ) a ausência de reuniões preparatórias para audiências públicas têm prejudicado, a participação da sociedade

( ) a ausência de reuniões preparatórias para audiências públicas não têm prejudicado a participação da sociedade

( ) nenhuma das anteriores

( ) não tenho informações

( ) a linguagem técnica no RIMA, tem prejudicado a efetiva participação da sociedade civil nos projetos

( ) a linguagem técnica no RIMA, não tem prejudicado a efetiva participação da sociedade civil nos projetos

( ) nenhuma das anteriores

( ) não tenho informações

( ) o RIMA tem sido um instrumento capaz de informar à sociedade sobre os impactos que ocorrerão com a implantação do empreendimento

( ) o RIMA não tem sido um instrumento capaz de informar à sociedade sobre os impactos que ocorrerão com a implantação do empreendimento

( ) nenhuma das anteriores

( ) não tenho informações

( ) a maioria das empresas de consultoria ambiental tem sido capaz de elaborar o RIMA em linguagem popular

( ) a maioria das empresas de consultoria ambiental não tem sido capaz de elaborar o RIMA em linguagem popular

( ) nenhuma das anteriores

( ) não tenho informações

7. De acordo com a legislação, a implantação de grandes projetos, deve propiciar uma compensação ambiental de pelo menos $0,5 \%$ dos custos total do empreendimento, para que seja aplicado em uma Unidade de Conservação. Pode se verificar, normalmente que:

( ) esta verba sempre tem sido liberada e corretamente aplicada

( ) esta verba nem sempre tem sido liberada ou corretamente aplicada

( ) nenhuma das anteriores

( ) não tenho informações

8. Os levantamentos socioeconômicos para os EIA/RIMA, geralmente:

( ) têm sido bem executados, sendo os diagnósticos de boa qualidade

( ) não têm sido bem executados, resultando em diagnósticos frágeis

( ) nenhuma das anteriores

( ) não tenho informações 
( ) indicam que a redução do tempo e dos recursos financeiros para elaboração dos EIA/RIMA, tem contribuído para fragilidade dos estudos

( ) indicam que não ocorrem reduções do tempo e dos recursos financeiros para a elaboração dos EIA/RIMA, os quais tem sido de ótima qualidade

( ) nenhuma das anteriores

( ) não tenho informações

9. Os acompanhamentos da execução das medidas mitigadoras, do cumprimento das exigências das licenças, dos programas de monitoramento e recuperação de áreas degradadas, através dos órgãos ambientais:

( ) tem sido bem efetuado, com pessoal técnico suficiente e capacitado

( ) não tem sido bem efetuado, com pessoal técnico suficiente e capacitado

( ) nenhuma das anteriores

( ) não tenho informações

( ) a falta de recursos dos órgãos ambientais tem impedido o acompanhamento das medidas após a fase de licença de instalação

( ) não há falta de recursos nos órgãos ambientais que possam impedir o acompanhamento das medidas após a fase de licença de instalação

( ) nenhuma das anteriores

( ) não tenho informações

10. O conflito de competências entre órgãos ambientais estaduais e o Ibama:

( ) tem sido verificado com freqüência nos EIA/RIMA

( ) não tem sido verificado com freqüência nos EIA/RIMA

( ) nenhuma das anteriores

( ) não tenho informações

11. As licenças prévias e de instalação tem sido dadas quando:

( ) há absoluta segurança na possibilidade de realização do empreendimento

( ) eventualmente ainda se têm dúvidas sobre a possibilidade de realização do empreendimento

( ) nenhuma das anteriores

( ) não tenho informações

12. A coordenação e formação da equipes multidisciplinares nos EIA:

( ) tem sido normalmente fraca na organização dos diagnósticos

( ) não tem sido normalmente fraca na organização dos diagnósticos

( ) nenhuma das anteriores

( ) não tenho informações

13. Os banco de dados nos órgãos ambientais, à disposição das empresas consultoras:

( ) tem sido, implantados nos Estados

( ) não tem sido implantados nos Estados

( ) nenhuma das anteriores

( ) não tenho informações 
14. A remuneração salarial nos órgãos ambientais, normalmente:

( ) não apresenta uma política salarial para o desenvolvimento de recursos humanos e de plano de cargo e salários

( ) apresenta uma política salarial para o desenvolvimento de recursos humanos e de plano de cargo e salários

( ) nenhuma das anteriores

( ) não tenho informações

15. Os órgãos ambientais podem contratar consultoria ambiental externa, quando os EIA/RIMA são complexos. Tem-se verificado que:

( ) as esporádicas contratações de consultoria externa, para avaliação de EIA/RIMA, por parte dos órgãos ambientais tem atrasado as emissões das licenças ambientais

( ) as freqüientes contratações de consultoria externa, para avaliação de EIA/RIMA, por parte dos órgãos ambientais, tem contribuído para emissões das licenças ambientais

( ) nenhuma das anteriores

( ) não tenho informações

16. Os relacionamentos entre empreendedores, órgãos ambientais e ONG's, quanto à gestão de EIA/RIMA, tem sido:

( ) com constante conflitos, mostrando evolução nos entendimentos

( ) com constante harmonia, não evidenciando conflitos

( ) nenhuma das anteriores

( ) não tenho informações

17. As possíveis carências técnicas de empresas habilitadas, têm contribuido para:

( ) fragilidade dos EIA/RIMAs apresentados, junto aos órgãos ambientais

( ) a manutenção da qualidade dos EIA/RIMA apresentados junto aos órgãos ambientais

( ) nenhuma das anteriores

( ) não tenho informações

18. Na divulgação e acesso às informações dos Estudos de Impacto Ambiental concluídos, observa-se que:

( ) as informações referentes sobre EIA/RIMA por parte dos órgãos ambientais, não tem sido divulgadas a contento

( ) as informações referentes sobre EIA/RIMA por parte do órgão ambiental tem sido divulgadas a contento

( ) nenhuma das anteriores

( ) não tenho informações

19. Os programas de controle ambiental, eventualmente exigidos na fase de instalação, normalmente:

( ) são completos e oferecem segurança para implantação definitiva dos projetos

( ) são incompletos e não oferecem segurança para implantação definitiva dos projetos

( ) nenhuma das anteriores 
( ) não tenho informações

20. A legislação ambiental brasileira, quanto aos EIA/RIMA (Resolução 001/86):

( ) tem sido eficaz na nossa realidade e não necessita de reformulação

( ) não tem sido plenamente eficaz e deveria ser reformulada

( ) nenhuma das anteriores

( ) não tenho informações

( ) há a necessidade de abreviar o processo de análise dos EIA/RIMA

( ) não há a necessidade de abreviar o processo de análise dos EIA/RIMA

( ) nenhuma das anteriores

( ) não tenho informações

21. Nos EIA/RIMA de grandes projetos os quais estão ligados a grandes interesses:

( ) não se observam pressões políticas para aprovação ou reprovação

( ) normalmente são observadas pressões políticas para aprovação ou reprovação

( ) nenhuma das anteriores

( ) não tenho informações

22. O sr. (sra.) gostaria de acrescentar mais algum item, que configure problema na estrutura ou funcionamento dos EIA/RIMA? 


\section{APÊNDICE 6 Análise do relatório de impacto ambiental (RIMA)}

Este documento cumpre exigência da Resolução do Conama 001/86 à Mineração Serra do Sossego para concessão de Licenciamento Prévio, Licença de Instalação e Licença de Operação ao empreendimento exploratório minerário de cobre, cujas jazidas são abundantes na região do Morro do Sossego e adjacências, integrantes da Província Mineral de Carajás.

Inicialmente, o Relatório de Controle Ambiental faz menções a respeito dos objetivos, justificativas e localização da empresa mineradora. Em seguida, tece comentários pormenorizados sobre características da mina, método de lavra (a céu aberto convencional, processos de escavamento e de transparente do minério tratamento/beneficiamento desses materiais); localização para a usina de concentração e da barragem dos rejeitos; construção de estradas e terminal de recepção, estocagem e embarque; suprimento de energia, água e outros insumos (captação e distribuição); geração de empregos (temporariedade) diretos e indiretos, geração, tratamento e destinação dos efluentes gasosos, particulados e líquidos, resíduos sólidos e ruídos.

A propósito, cabe o registro do que já foi comentado em outro capítulo deste trabalho abordagem concernente aos aspectos físicos, biológicos e socioeconômicos do RIMA, ora em apreciação.

Convém salientar que na avaliação da MSS os impactos ambientais decorrentes do empreendimento devem ser enfocados consoante às etapas de exploração mineral.

Desse modo, para os impactos na Etapa de Implantação, cujo cronograma prevê um período de quatro anos, o RIMA apresenta um quadro demonstrativo onde são computadas a discriminação dos impactos, medidas mitigadoras e avaliações correspondentes. São delineadas, portanto, alterações climáticas, da qualidade do ar, da morfologia do relevo e da paisagem, do sistema de drenagem; geração de ruído, intensificação da erosão e assoreamentos, contaminação do solo e das águas, manutenção e supressão da vegetação, redução de habitats e fauna; geração de empregos, rendas e tributos, aumento da população e ocupação humana, reflexos na infraestrutura de serviços e rodoviário, e ações no patrimônio arqueológico. A cada impacto são propostas medidas de mitigação com vistas ao controle, manutenção, reabilitação, sistemas, gestão e ações com a garantia de atingir efeitos satisfatórios. As avaliações identificam a situação original e a subseqüente à implantação do empreendimento, além de sinalizar as conseqüências derivadas dessa etapa. 
O RIMA discorre, igualmente, por intermédio de quadro demonstrativo sobre a avaliação dos impactos atinentes à Etapa de Operação do empreendimento, centrando as observações e proposições nas mesmas variantes analisadas no item anterior, acrescentadas de outros enfoques, como, por exemplo, incômodos e riscos rodoviários, mercado do cobre, negócios e importância política da área.

$\mathrm{O}$ documento revela, ainda, em quadro específico, as avaliações sobre os impactos e medidas de mitigação alusivos à Etapa de Fechamento do empreendimento.

Quanto às medidas mitigadoras o RIMA descreve as estratégicas direcionadas a minimizar/ reduzir/eliminar os impactos desdobrados, procurando reabilitar aqueles não minimizáveis e compensar os que não podem ser eliminados, reduzidos ou reabilitados através de ações de controle, sistemas, gestão, planos e programas específicos.

O RIMA, ao aquilatar as tendências da qualidade ambiental da área objeto do empreendimento, trabalha na presunção de duas possíveis realidades. Aventa a hipótese da não implantação do Projeto, afirmando que a área do Sossego continuará submetida aos processos de ocupação e exploração atual, sem qualquer perspectiva de desenvolvimento econômico e bemestar social para a população local. Desenha, todavia, um cenário mais promissor para a região como decorrência natural da implantação da exploração industrial do minério ali abundante, subvalorizando os impactos negativos e megavalorizando os positivos, realçando as repercussões socieconômicas e ambientais, consoante aplicação de planos e programas a serem implementados mesmo após o fechamento do empreendimento.

O documento, destaca as campanhas de monitoramento a serem desencadeadas em todas as fases do empreendimento, as quais integram o PCA da MSS. Desse modo, estão previstos monitoramentos meteorológicos, da qualidade do ar, dos níveis de ruído, da qualidade das águas de níveis piezométricos e fluviométricos, de níveis de radiação, de geração de ruídos, florístico, faunístico, socioeconômicos, de doenças endêmicas e arqueológicas. É valida a informação que o RIMA ostenta um conjunto de figuras ilustrativas (localização, detalhamento e imagem de satélite da área do projeto, além de fluxograma de produção de concentrado), bem como documentação fotográfica (conjunto de seis fotos reveladoras do relevo, paisagem de vegetação e antrópica).

Tendo em vista que a elaboração de um RIMA constitui-se em um instrumento previsto pela legislação ambiental onde a comunidade esta sujeita aos impactos causados pela implantação do empreendimento, é necessário que tal documento atinja o público-alvo mediante uma linguagem acessível ao leigo. 
Esta constatação enseja algumas considerações a seguir:

Constatou-se a predominância no texto do RIMA de termos técnico-científicos, como se fora direcionado unicamente à apreciação acadêmica e de profissionais especializados na matéria. Alguns trechos ostentam linguagem hermética, incompreensível aos leigos, o que evidencia dificuldades de compreensão ou entendimento de grande parte da população envolvida. Esta realidade afeta, sobremaneira a absorção das campanhas de esclarecimento e de educação ambiental, por exemplo, dirigidas a população de nenhuma, baixa e até média escolaridades e níveis culturais.

Ademais, vislumbrou-se um horizonte restrito na divulgação do documento, o qual deveria ser difundida com maior eficácia na comunidade, de preferência nas organizações civis da sociedade, tais como associação de moradores, centros comunitários, grupos religiosos, recreativos, filantrópicos, culturais, entidades classistas, segmentos partidários e demais pessoas jurídicas de direito privado.

$\mathrm{O}$ aspecto socieconômico suscita algumas observações que se reputam pertinentes e relevantes. A criação de empregos, se acarreta impacto positivo na implantação do projeto, enseja a adoção de projetos e outras iniciativas que atenuem os desdobramentos advindos da redução e eliminação de postos de trabalho previstas às etapas operacionais e de fechamento do empreendimento.

Acresce que o inchaço populacional pode propiciar desdobramento indesejáveis na área da segurança, como criminalidade e violência, surgimento de favelas, favorecimento à prostituição infanto-juvenil, aumento de moradias insalubres, incidência de moléstias e obsoletismo dos serviços públicos; enfim desenha-se um panorama de miséria e exclusão social.

Daí a necessidade na tomada de providências alusivas à capacitação dos recursos humanos, estímulo à abertura de microempresas, ordenação da informalidade, políticas sociais de habitação, saneamento, educação, conscientização ambiental, e demais ações de ordem pública e de responsabilidade social da MSS, que, efetivamente contribua para a consolidação da democracia, via pleno exercício da cidadania.

Espera-se que os resultados visados pelo empreendimento sejam plenamente viabilizados, pela implantação da infra-estrutura operacional e pelo desenvolvimento dos programas-piloto de educação ambiental, treinamento e especialização técnica, introdução de novas opções tecnológicas na mineração, recuperação de áreas degradadas, repasse de tecnologia, difusão do conhecimento e incremento na parceria institucional multidisciplinar (devido, principalmente, à 
reduzida menção do envolvimento da MSS com instituições do porte da CNEN, MPEG, FCAP, UFPA, SECTAM, SEICOM e outras unidades de pesquisa e fiscalização atuantes no setor). Ficou igualmente patente, a ausência do cronograma financeiro do empreendimento. 


\section{APÊNDICES 7 Quadro resumo dos questionários}

\begin{tabular}{|c|c|}
\hline & $\begin{array}{c}\text { TOTAL DE } \\
\text { RESPOSTAS (\%) }\end{array}$ \\
\hline \multicolumn{2}{|l|}{ 1. Normalmente, nos EIA que tem participado, os Termos de Referência: } \\
\hline são documentos muito genéricos & 50,00 \\
\hline são documentos muito precisos & 21,43 \\
\hline nenhuma das anteriores & 10,71 \\
\hline não tenho informações & 14,29 \\
\hline brancos & 3,57 \\
\hline nulos & 0,00 \\
\hline são documentos pouco objetivos & 53,57 \\
\hline são documentos muito objetivos & 21,43 \\
\hline nenhuma das anteriores & 10,71 \\
\hline não tenho informações & 14,29 \\
\hline brancos & 0,00 \\
\hline \multicolumn{2}{|l|}{ nulos } \\
\hline são documentos que deveriam ser anexados aos EIA & 64,29 \\
\hline são documentos que não deveriam ser anexados aos EIA & 10,71 \\
\hline nenhuma das anteriores & 10,71 \\
\hline não tenho informações & 10,71 \\
\hline brancos & 3,57 \\
\hline nulos & 0,00 \\
\hline \begin{tabular}{lcccc|} 
são documentos que necessitam & de & instrumentos & normativos \\
complementares à legislação federal.
\end{tabular} & 53,57 \\
\hline $\begin{array}{l}\text { não são documentos que necessitam de instrumentos normativos } \\
\text { complementares à legislação federal. }\end{array}$ & 17,86 \\
\hline nenhuma das anteriores & 7,14 \\
\hline não tenho informações & 17,86 \\
\hline brancos & 0,00 \\
\hline nulos & 3,57 \\
\hline \multicolumn{2}{|c|}{ 2. Quanto aos Recursos Financeiros destinados à elaboração dos EIA/RIMA, normalmente: } \\
\hline $\begin{array}{l}\text { o principal critério das licitações (maior peso) é a qualificação da equipe } \\
\text { técnica }\end{array}$ & 7,14 \\
\hline o principal critério das licitações é o menor preço dos serviços & 57,14 \\
\hline nenhuma das anteriores & 3,57 \\
\hline não tenho informações & 32,14 \\
\hline brancos & 0,00 \\
\hline nulos & 0,00 \\
\hline $\begin{array}{l}\text { tem sido direcionado para a escolha das empresas mais qualificadas, mesmo } \\
\text { com custos maiores }\end{array}$ & 10,71 \\
\hline
\end{tabular}




\begin{tabular}{|c|c|}
\hline $\begin{array}{l}\text { tem sido direcionado para a escolha de empresas pouco qualificadas, que } \\
\text { apresentam os menores custos }\end{array}$ & 39,29 \\
\hline nenhuma das anteriores & 7,14 \\
\hline não tenho informações & 28,57 \\
\hline brancos & 10,71 \\
\hline nulos & 3,57 \\
\hline tem proporcionado estudos detalhados e de grande profundidade & 14,29 \\
\hline tem gerado estudos fracos, muito simplificados e pouco seguros & 53,57 \\
\hline nenhuma das anteriores & 14,29 \\
\hline não tenho informações & 7,14 \\
\hline brancos & 7,14 \\
\hline nulos & 3,57 \\
\hline $\begin{array}{l}\text { tem provocado cronogramas apertados, com pouco tempo para os estudos de } \\
\text { campo }\end{array}$ & 60,71 \\
\hline $\begin{array}{l}\text { tem provocado cronogramas amplos, oferecendo tempo suficiente para } \\
\text { detalhados estudos de campo }\end{array}$ & 7,14 \\
\hline nenhuma das anteriores & 10,71 \\
\hline não tenho informações & 7,14 \\
\hline brancos & 10,71 \\
\hline nulos & 3,57 \\
\hline \multicolumn{2}{|l|}{ 3. Quanto aos Prazos para execução do EIA, o tempo disponível: } \\
\hline $\begin{array}{l}\text { tem sido suficiente em decorrência da complexidade dos estudos nas } \\
\text { diversas regiões do Brasil }\end{array}$ & 17,86 \\
\hline $\begin{array}{l}\text { não tem sido suficiente em decorrência da complexidade dos estudos nas } \\
\text { diversas regiões do Brasil }\end{array}$ & 53,57 \\
\hline nenhuma das anteriores & 14,29 \\
\hline não tenho informações & 14,29 \\
\hline brancos & 0,00 \\
\hline nulos & 0,00 \\
\hline $\begin{array}{l}\text { não atende às dimensões dos empreendimentos e tem contribuído para } \\
\text { fragilidade dos estudos }\end{array}$ & 53,57 \\
\hline $\begin{array}{l}\text { atende às dimensões dos empreendimentos e tem contribuído para a } \\
\text { efetividade dos estudos }\end{array}$ & 10,71 \\
\hline nenhuma das anteriores & 17,86 \\
\hline não tenho informações & 10,71 \\
\hline brancos & 7,14 \\
\hline nulos & 0,00 \\
\hline \multicolumn{2}{|c|}{$\begin{array}{l}\text { 4. Os EIA's quanto à sazonalidade dos estudos em ambientes complexos e com estação } \\
\text { definidas, normalmente: }\end{array}$} \\
\hline são exigidos estudos respeitando-se a sazonalidade & 28,57 \\
\hline os estudos são realizados em apenas uma época do ano & 32,14 \\
\hline
\end{tabular}




\begin{tabular}{|c|c|}
\hline nenhuma das anteriores & 7,14 \\
\hline não tenho informações & 28,57 \\
\hline brancos & 0,00 \\
\hline nulos & 3,57 \\
\hline \multicolumn{2}{|c|}{$\begin{array}{l}\text { 5. Quando na Área de Influência Direta dos projetos, ocorrem Unidades de Conservaç̃o ou } \\
\text { Reservas Indígenas: }\end{array}$} \\
\hline são realizados estudos particularizados para estas áreas protegidas & 32,14 \\
\hline não são realizados estudos particularizados para estas áreas protegidas & 42,86 \\
\hline nenhuma das anteriores & 3,57 \\
\hline não tenho informações & 17,86 \\
\hline brancos & 0,00 \\
\hline nulos & 3,57 \\
\hline \multicolumn{2}{|c|}{ 6. Nos EIA normalmente a participação da sociedade civil em Audiências Públicas: } \\
\hline $\begin{array}{l}\text { o RIMA tem propiciado a participação efetiva do público nas discussões } \\
\text { sobre o empreendimento }\end{array}$ & 21,43 \\
\hline $\begin{array}{l}\text { o RIMA não tem propiciado a participação efetiva do público nas discussões } \\
\text { sobre o empreendimento }\end{array}$ & 57,14 \\
\hline nenhuma das anteriores & 10,71 \\
\hline não tenho informações & 7,14 \\
\hline brancos & 3,57 \\
\hline nulos & 0,00 \\
\hline $\begin{array}{l}\text { a ausência de reuniões preparatórias para audiências públicas tem } \\
\text { prejudicado, a participação da sociedade }\end{array}$ & 64,29 \\
\hline $\begin{array}{l}\text { a ausência de reuniões preparatórias para audiências públicas não tem } \\
\text { prejudicado a participação da sociedade }\end{array}$ & 10,71 \\
\hline nenhuma das anteriores & 3,57 \\
\hline não tenho informações & 10,71 \\
\hline brancos & 7,14 \\
\hline nulos & 3,57 \\
\hline $\begin{array}{l}\text { a linguagem técnica no RIMA, tem prejudicado a efetiva participação da } \\
\text { sociedade civil nos projetos }\end{array}$ & 53,57 \\
\hline $\begin{array}{l}\text { a linguagem técnica no RIMA, não tem prejudicado a efetiva participação da } \\
\text { sociedade civil nos projetos }\end{array}$ & 10,71 \\
\hline nenhuma das anteriores & 3,57 \\
\hline não tenho informações & 21,43 \\
\hline brancos & 7,14 \\
\hline nulos & 3,57 \\
\hline $\begin{array}{l}\text { o RIMA tem sido um instrumento capaz de informar à sociedade sobre os } \\
\text { impactos que ocorrerão com a implantação do empreendimento }\end{array}$ & 21,43 \\
\hline $\begin{array}{l}\text { o RIMA não tem sido um instrumento capaz de informar à sociedade sobre } \\
\text { os impactos que ocorrerão com a implantação do empreendimento }\end{array}$ & 60,71 \\
\hline nenhuma das anteriores & 7,14 \\
\hline
\end{tabular}




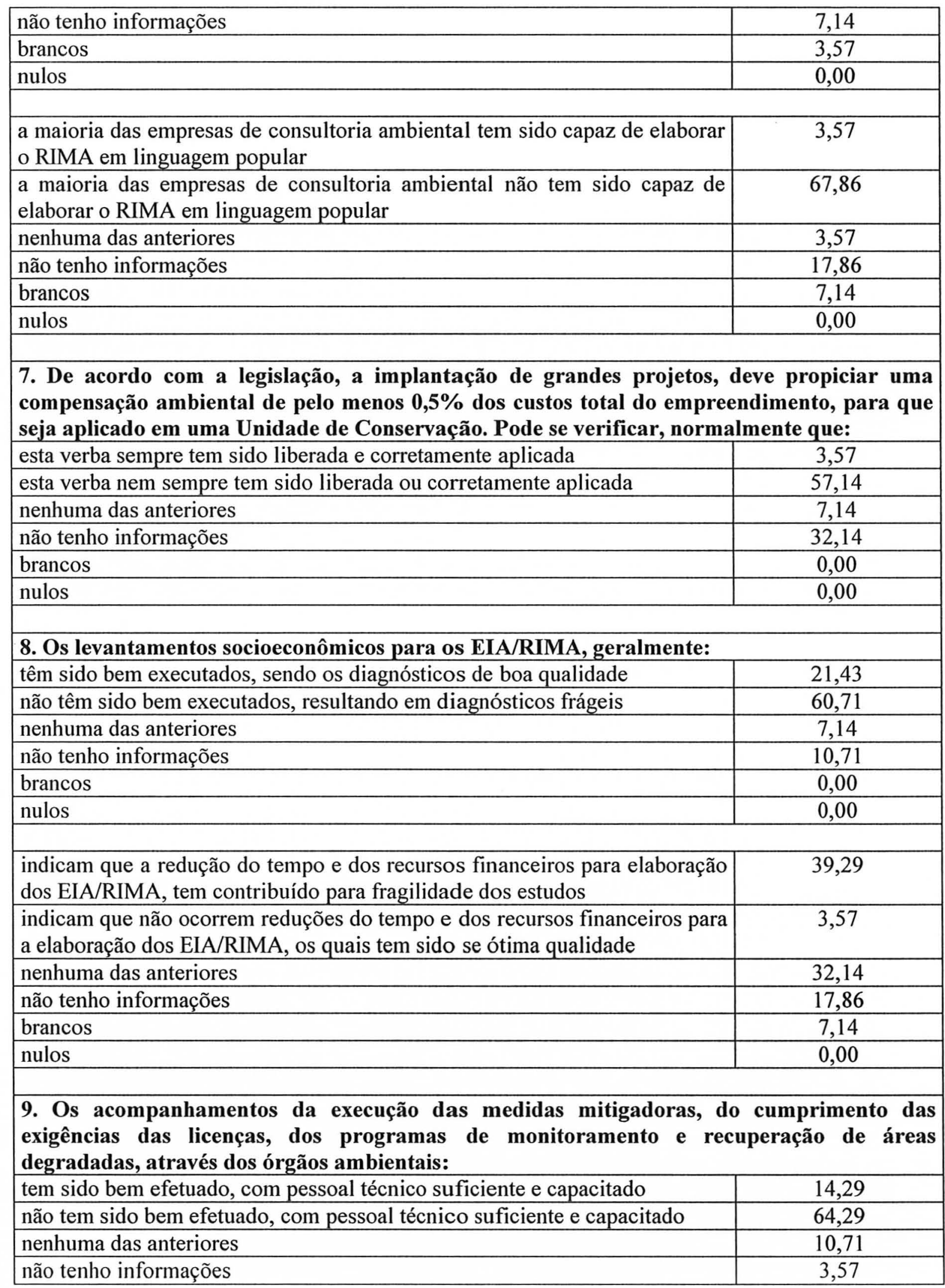




\begin{tabular}{|c|c|}
\hline brancos & 7,14 \\
\hline nulos & 0,00 \\
\hline $\begin{array}{l}\text { a falta de recursos dos órgãos ambientais tem impedido o acompanhamento } \\
\text { das medidas após a fase de licença de instalação }\end{array}$ & 75,00 \\
\hline $\begin{array}{l}\text { não há falta de recursos nos órgãos ambientais que possam impedir o } \\
\text { acompanhamento das medidas após a fase de licença de instalação }\end{array}$ & 7,14 \\
\hline nenhuma das anteriores & 7,14 \\
\hline não tenho informações & 3,57 \\
\hline brancos & 3,57 \\
\hline nulos & 3,57 \\
\hline \multicolumn{2}{|l|}{ 10. O conflito de competências entre órgãos ambientais estaduais e o Ibama: } \\
\hline tem sido verificado com freqüência nos EIA/RIMA & 64,29 \\
\hline não tem sido verificado com freqüência nos EIA/RIMA & 14,29 \\
\hline nenhuma das anteriores & 7,14 \\
\hline não tenho informações & 14,29 \\
\hline brancos & 0,00 \\
\hline nulos & 0,00 \\
\hline \multicolumn{2}{|l|}{ 11. As licenças prévia e de instalação tem sido dadas quando: } \\
\hline há absoluta segurança na possibilidade de realização do empreendimento & 10,71 \\
\hline $\begin{array}{l}\text { eventualmente ainda se têm dúvidas sobre a possibilidade de realização do } \\
\text { empreendimento }\end{array}$ & 71,43 \\
\hline nenhuma das anteriores & 10,71 \\
\hline não tenho informações & 7,14 \\
\hline brancos & 0,00 \\
\hline nulos & 0,00 \\
\hline \multicolumn{2}{|l|}{ 12. A coordenação e formação da equipes multidisciplinares nos EIA: } \\
\hline tem sido normalmente fraca na organização dos diagnósticos & 42,86 \\
\hline não tem sido normalmente fraca na organização dos diagnósticos & 32,14 \\
\hline nenhuma das anteriores & 7,14 \\
\hline não tenho informações & 17,86 \\
\hline brancos & 0,00 \\
\hline nulos & 0,00 \\
\hline \multicolumn{2}{|c|}{ 13. Os banco de dados nos órgãos ambientais, à disposição das empresas consultoras: } \\
\hline têm sido, implantados nos Estados & 17,86 \\
\hline não têm sido implantados nos Estados & 50,00 \\
\hline nenhuma das anteriores & 7,14 \\
\hline não tenho informações & 25,00 \\
\hline brancos & 0,00 \\
\hline nulos & 0,00 \\
\hline
\end{tabular}




\begin{tabular}{|c|c|}
\hline humanos e de plano de cargo e salários & \\
\hline $\begin{array}{l}\text { apresenta uma política salarial para o desenvolvimento de recursos humanos } \\
\text { e de plano de cargo e salários }\end{array}$ & 0,00 \\
\hline nenhuma das anteriores & 3,57 \\
\hline não tenho informações & 32,14 \\
\hline brancos & 0,00 \\
\hline nulos & 0,00 \\
\hline \multicolumn{2}{|c|}{$\begin{array}{l}\text { 15. Os órgãos ambientais podem contratar consultoria ambiental externa, quando os } \\
\text { EIA/RIMA são complexos. Tem-se verificado que: }\end{array}$} \\
\hline $\begin{array}{l}\text { às esporádicas contratações de consultoria externa, para avaliação de } \\
\text { EIA/RIMA, por parte dos órgãos ambientais tem atrasado as emissões das } \\
\text { licenças ambientais }\end{array}$ & 14,29 \\
\hline $\begin{array}{l}\text { as freqüentes contratações de consultoria externa, para avaliação de } \\
\text { EIA/RIMA, por parte dos órgãos ambientais, têm contribuído para emissões } \\
\text { das licenças ambientais }\end{array}$ & 17,86 \\
\hline nenhuma das anteriores & 32,14 \\
\hline não tenho informações & 35,71 \\
\hline brancos & 0,00 \\
\hline nulos & 0,00 \\
\hline \multicolumn{2}{|c|}{$\begin{array}{l}\text { 16. Os relacionamentos entre empreendedores, órgãos ambientais e ONG's, quanto à gestão } \\
\text { de EIA/RIMA, tem sido: }\end{array}$} \\
\hline com constantes conflitos, mostrando evolução nos entendimentos & 67,86 \\
\hline com constante harmonia, não evidenciando conflitos & 3,57 \\
\hline nenhuma das anteriores & 17,86 \\
\hline não tenho informações & 10,71 \\
\hline brancos & 0,00 \\
\hline nulos & 0,00 \\
\hline \multicolumn{2}{|c|}{ 17. As possíveis carências técnicas de empresas habilitadas, têm contribuído para: } \\
\hline fragilidade dos EIA/RIMA apresentados, junto aos órgãos ambientais & 75,00 \\
\hline $\begin{array}{l}\text { a manutenção da qualidade dos EIA/RIMA apresentados junto aos órgãos } \\
\text { ambientais }\end{array}$ & 0,00 \\
\hline nenhuma das anteriores & 14,29 \\
\hline não tenho informações & 10,71 \\
\hline brancos & 0,00 \\
\hline nulos & 0,00 \\
\hline \multicolumn{2}{|c|}{$\begin{array}{l}\text { 18. Na divulgação e acesso às informações dos Estudos de Impacto Ambiental concluídos, } \\
\text { observa-se que: }\end{array}$} \\
\hline $\begin{array}{l}\text { as informações referentes sobre EIA/RIMA por parte dos órgãos ambientais, } \\
\text { não têm sido divulgadas a contento }\end{array}$ & 67,86 \\
\hline $\begin{array}{l}\text { as informações referentes sobre EIA/RIMA por parte do órgãos ambientais } \\
\text { têm sido divulgadas a contento }\end{array}$ & 14,29 \\
\hline nenhuma das anteriores & 3,57 \\
\hline não tenho informações & 14,29 \\
\hline
\end{tabular}




\begin{tabular}{|c|c|}
\hline brancos & 0,00 \\
\hline nulos & 0,00 \\
\hline \multicolumn{2}{|c|}{$\begin{array}{l}\text { 19. Os programas de controle ambiental, eventualmente exigidos na fase de instalação, } \\
\text { normalmente: }\end{array}$} \\
\hline $\begin{array}{l}\text { são completos e oferecem segurança para implantação definitiva dos } \\
\text { projetos }\end{array}$ & 10,71 \\
\hline $\begin{array}{l}\text { são incompletos e não oferecem segurança para implantação definitiva dos } \\
\text { projetos }\end{array}$ & 50,00 \\
\hline nenhuma das anteriores & 25,00 \\
\hline não tenho informações & 14,29 \\
\hline brancos & 0,00 \\
\hline nulos & 0,00 \\
\hline \multicolumn{2}{|l|}{ 20. A legislação ambiental brasileira, quanto aos EIA/RIMA (Resolução 001/86): } \\
\hline tem sido eficaz na nossa realidade e não necessita de reformulação & 10,71 \\
\hline não tem sido plenamente eficaz e deveria ser reformulada & 67,86 \\
\hline nenhuma das anteriores & 10,71 \\
\hline não tenho informações & 10,71 \\
\hline brancos & 0,00 \\
\hline nulos & 0,00 \\
\hline há a necessidade de abreviar o processo de análise dos EIA/RIMA & 39,29 \\
\hline não há a necessidade de abreviar o processo de análise dos EIA/RIMA & 25,00 \\
\hline nenhuma das anteriores & 25,00 \\
\hline não tenho informações & 3,57 \\
\hline brancos & 7,14 \\
\hline nulos & 0,00 \\
\hline \multicolumn{2}{|c|}{ 21. Nos EIA/RIMA de grandes projetos os quais estão ligados a grandes interesses: } \\
\hline não se observam pressões políticas para aprovação ou reprovação & 0,00 \\
\hline $\begin{array}{|lccccc|}\begin{array}{l}\text { normalmente são observadas pressões políticas para aprovação ou } \\
\text { reprovação }\end{array} & \\
\end{array}$ & 89,29 \\
\hline nenhuma das anteriores & 3,57 \\
\hline não tenho informações & 7,14 \\
\hline brancos & 0,00 \\
\hline \begin{tabular}{|l|} 
nulos \\
\end{tabular} & 0,00 \\
\hline
\end{tabular}


APÊNDICES 8 - Levantamento das falhas estruturais sobre EIA/RIMA

\begin{tabular}{|c|c|c|c|c|c|}
\hline Item de análise & Critério & Indicadores & Problemas levantados & $\begin{array}{c}\text { Pontos de } \\
\text { comprometimento no } \\
\text { EIA/RIMA DA MSS }\end{array}$ & Alternativas \\
\hline Termo de Referência & $\begin{array}{l}\text { Conama 01/86 } \\
\text { Conama } 237\end{array}$ & $\begin{array}{l}\text { Documento } \\
\text { disponível } \\
\text { Detalhamento } \\
\text { mais específico }\end{array}$ & $\begin{array}{l}\text { Não existência como anexo no } \\
\text { EIA/RIMA } \\
\text { Extremamente genéricos } \\
\text { Falta de objetividade }\end{array}$ & $\begin{array}{l}\text { Não constava no processo } \\
\text { da MSS o Termo de } \\
\text { Referência }\end{array}$ & $\begin{array}{l}\text { Inclusão do Termo de Referência como } \\
\text { anexo do EIA/RIMA }\end{array}$ \\
\hline $\begin{array}{l}\text { Custos de Elaboração } \\
\text { do EIA }\end{array}$ & $\begin{array}{l}\text { Recursos para os } \\
\text { estudos }\end{array}$ & \begin{tabular}{|lr}
$\begin{array}{l}\text { Amplitude } \\
\text { diagnósticos }\end{array}$ & dos \\
Dificuldade & de \\
acesso &
\end{tabular} & $\begin{array}{l}\text { Critério de licitação pelo menor preço } \\
\text { de serviços } \\
\text { Concorrência não qualificada } \\
\text { Falta de detalhamento no EIA/RIMA } \\
\text { u sua profundidade } \\
\text { Qualidade fraca do estudo } \\
\text { Cronogramas apertados }\end{array}$ & Custos não informados & $\begin{array}{l}\text { Informar a sociedade dos custos de } \\
\text { elaboração do EIA/RIMA, com a } \\
\text { finalidade de se fazer uma correlação } \\
\text { entre o valor do empreendimento e do } \\
\text { estudo }\end{array}$ \\
\hline $\begin{array}{l}\text { Prazo para execução } \\
\text { do EIA }\end{array}$ & $\begin{array}{l}\text { Complexidade do } \\
\text { estudo }\end{array}$ & $\begin{array}{l}\text { Dimensões do } \\
\text { empreendimento } \\
\text { Problemas } \\
\text { ambientais } \\
\text { Biodiversidade } \\
\text { presente }\end{array}$ & Tempo curto & $\begin{array}{l}\text { Os estudos iniciaram em } \\
1999 \text { com o plano de } \\
\text { aproveitamento } \\
\text { econômico, concepção do } \\
\text { empreendimento, estudo } \\
\text { de vulnerabilidade, } \\
\text { investigações } \\
\text { monitoramento e estudos } \\
\text { ambientais- EIA/RIMA. }\end{array}$ & $\begin{array}{l}\text { Aumentar o prazo para elaboração dos } \\
\text { estudos }\end{array}$ \\
\hline Sazonalidade & $\begin{array}{l}\text { Levantamento no } \\
\text { inverno e verão }\end{array}$ & \begin{tabular}{|l|} 
Características \\
diferenciadas em \\
inverno e verão \\
\end{tabular} & $\begin{array}{l}\text { Estudo sem sazonalidade, refeito } \\
\text { posteriormente }\end{array}$ & $\begin{array}{l}\text { Dados não apresentados } \\
\text { na Audiência Pública e na } \\
\text { LP }\end{array}$ & $\begin{array}{l}\text { Análise mais rigorosa por parte dos } \\
\text { órgãos ambientais, referentes a } \\
\text { sazonalidade }\end{array}$ \\
\hline $\begin{array}{lr}\text { Unidades } & \mathrm{de} \\
\text { Conservação } & \mathrm{e} \\
\text { Reservas Indigenas } & \end{array}$ & $\begin{array}{l}\text { Lei } 9.985 \text {, de } 18 \text { de } \\
\text { julho de } 2000- \\
\text { SNUC }\end{array}$ & $\begin{array}{l}\text { Áreas especialmente } \\
\text { protegidas }\end{array}$ & $\begin{array}{l}\text { Falta de estudos particularizados para } \\
\text { unidades de conservação } \\
\text { Estudos ambientais para Reserva } \\
\text { Indígena }\end{array}$ & $\begin{array}{l}\text { Não foi exigido por parte } \\
\text { do órgão ambiental um } \\
\text { estudo sobre a unidade de } \\
\text { conservação }\end{array}$ & $\begin{array}{l}\text { Devem ser realizados estudos } \\
\text { particularizados para as Unidades de } \\
\text { Conservação e para Reserva Indígenas } \\
\text { localizadas na AID dos projetos }\end{array}$ \\
\hline $\begin{array}{l}\text { Participação da } \\
\text { sociedade civil em } \\
\text { audiências públicas }\end{array}$ & \begin{tabular}{|lr} 
Resolução & $09 / 86-$ \\
Dispõe & sobre \\
audiências & \\
públicas & \\
Ampla divulgação \\
\end{tabular} & $\begin{array}{l}\text { RIMA em linguagem } \\
\text { popular }\end{array}$ & $\begin{array}{l}\text { Linguagem técnica nos estudos de } \\
\text { impacto ambiental } \\
\text { Ausência de reuniões preparatórias } \\
\text { para audiências públicas }\end{array}$ & $\begin{array}{l}\text { Ocorreu apenas uma } \\
\text { audiência em Canã dos } \\
\text { Carajás, para discutir a } \\
\text { implantação do projeto }\end{array}$ & $\begin{array}{l}\text { Criação de audiências públicas } \\
\text { intermediárias }\end{array}$ \\
\hline
\end{tabular}




\begin{tabular}{|c|c|c|c|c|c|}
\hline $\begin{array}{l}\text { Compensação } \\
\text { Ambiental relativa à } \\
\text { implantação de } \\
\text { grandes projetos }\end{array}$ & \begin{tabular}{|l|} 
Resolução Conama \\
$002 / 96$ - aplicação \\
em unidade de \\
conservação de no \\
mínimo 0,5\% do \\
custo do EIA
\end{tabular} & Custo do EIA & $\begin{array}{l}\text { Ausência de aplicação do } 0,5 \% \text { em } \\
\text { unidades de conservação }\end{array}$ & $\begin{array}{l}\text { Não houve consenso na } \\
\text { aplicação do recurso entre } \\
\text { IBAMA e SECTAM }\end{array}$ & $\begin{array}{l}\text { Aplicação da compensação ambiental na } \\
\text { elaboração e implementação de plano de } \\
\text { manejo }\end{array}$ \\
\hline \begin{tabular}{|l|} 
Levantamento \\
Socioeconômico para \\
estudo de impacto \\
ambiental \\
\end{tabular} & \begin{tabular}{|l|} 
Resolução Conama \\
$01 / 86$ \\
Conama 237/97
\end{tabular} & $\begin{array}{|lr|}\text { Menores } & \text { recursos } \\
\text { para } & \text { área } \\
\text { socioeconômica } & \end{array}$ & $\begin{array}{l}\text { Fragilidade dos levantamentos } \\
\text { socioeconômicos } \\
\text { Ausência de propostas de inserção } \\
\text { social do projeto no município. }\end{array}$ & $\begin{array}{l}\text { Diagnóstico deficiente e } \\
\text { falhas nos programas }\end{array}$ & $\begin{array}{l}\text { Todo o levantamento econômico do } \\
\text { projeto deveria ser refeito }\end{array}$ \\
\hline \begin{tabular}{|lr} 
Acompanhamento da \\
execução & das \\
medidas mitigadoras, \\
da verificação & do \\
cumprimento & das \\
exigências & das \\
licenças & e \\
programas & de \\
monitoramento e dos \\
programas & de \\
recuperação & \\
\end{tabular} & Órgão Ambiental & $\begin{array}{ll}\text { Equipe } & \text { Técnica } \\
\text { Recursos } & \text { Financeiros }\end{array}$ & $\begin{array}{l}\text { Ausência de verificação do } \\
\text { acompanhamento de execução das } \\
\text { medidas propostas. } \\
\text { Falta de recursos do órgão ambiental } \\
\text { para custear os deslocamentos } \\
\text { Número reduzido de técnicos } \\
\text { existentes no órgão ambiental } \\
\text { Extensão do Estado do Pará }\end{array}$ & $\begin{array}{l}\text { No caso da MSS o projeto } \\
\text { ainda se encontra na fase } \\
\text { de implantação }\end{array}$ & $\begin{array}{l}\text { Realização de Monitoramento das } \\
\text { Medidas Mitigadoras e compensatórias, } \\
\text { com os recursos arrecadados das taxas } \\
\text { das licenças e aumentar o número de } \\
\text { técnicos dos órgãos ambientais }\end{array}$ \\
\hline $\begin{array}{l}\text { Conflito } \\
\text { competências }\end{array}$ & $\begin{array}{l}\text { Lei n. }{ }^{\circ} 6.938 \text {, de } \\
31 \text { de Agosto de } \\
1981 \text {, que institui a } \\
\text { PNMA }\end{array}$ & $\begin{array}{l}\text { Ações do IBAMA e } \\
\text { dos r Órgãos } \\
\text { ambientais estaduais }\end{array}$ & $\begin{array}{l}\text { Ações independentes dos órgãos } \\
\text { ambientais }\end{array}$ & - & Interações entre os órgãos ambientais \\
\hline Licença Prévia & $\begin{array}{l}\text { Lei } \mathrm{n}^{\circ} \text { 6.938/81- } \\
\text { PNMA inciso IV } \\
\text { do artigo } 9^{\circ}, 10^{\circ} \\
\text { Conama } 237 / 97 \\
\end{array}$ & $\begin{array}{l}\text { Aprovação do EIA } \\
\text { Definição dos PCA }\end{array}$ & $\begin{array}{l}\text { Fragilidade dos levantamentos } \\
\text { Socioeconômicos } \\
\text { Informações insuficientes } \\
\end{array}$ & - & $\begin{array}{l}\text { A licença prévia foi emitida, sem a } \\
\text { definição dos itens mencionados. }\end{array}$ \\
\hline Licença Instalação & $\begin{array}{l}\text { Lei } \mathrm{n}^{\circ} 6.938 / 81- \\
\text { PNMA inciso IV } \\
\text { do artigo } 9^{\circ}, 10^{\circ} \\
\text { Conama } 237 / 97\end{array}$ & \begin{tabular}{ll|} 
Aprovação & dos \\
PCA/SGA/PDS &
\end{tabular} & 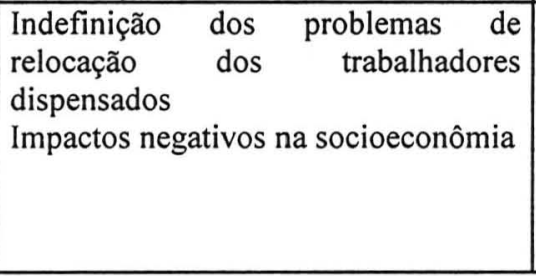 & \begin{tabular}{|l|} 
Propostas ainda como \\
Programa de Trabalho - \\
PDS \\
Fragilidade \\
programas sociais \\
Ausência da apresentação \\
do estudo da sazonalidade \\
\end{tabular} & $\begin{array}{l}\text { A licença de Instalação foi emitida, sem } \\
\text { a definição dos itens mencionados. }\end{array}$ \\
\hline
\end{tabular}


APÊNDICES 9 - Outros fatores que interferem na eficiência do EIA/RIMA

\begin{tabular}{|c|c|c|c|c|c|}
\hline Item de análise & Critério & Indicadores & Problemas levantados & \begin{tabular}{|l|} 
Pontos de comprometi- \\
mento no EIA/RIMA DA \\
MSS \\
\end{tabular} & Alternativas \\
\hline $\begin{array}{l}\text { Coordenação e } \\
\text { formação da equipe } \\
\text { multidissciplinar }\end{array}$ & $\begin{array}{l}\text { Coordenação eficiente } \\
\text { da consultoria }\end{array}$ & $\begin{array}{l}\text { Equipe } \\
\text { multidisciplinar }\end{array}$ & Coordenação fraca dos trabalhos & $\begin{array}{l}\text { Esta informação não pode } \\
\text { ser averiguada, junto ao } \\
\text { órgão ambiental e nem } \\
\text { junto a MSS. }\end{array}$ & - \\
\hline $\begin{array}{l}\text { Ausência de um banco } \\
\text { de dados nos órgãos } \\
\text { ambientais }\end{array}$ & $\begin{array}{l}\text { Lei .6.831/86 - } \\
\text { (PNMA) - SISNIMA }\end{array}$ & $\begin{array}{|lr|}\text { Monitoramento } & \text { de } \\
\text { parâmetros } & \text { da } \\
\text { qualidade do ambiente }\end{array}$ & $\begin{array}{l}\text { Falta de informações dos fatores ligados } \\
\text { tradicionalmente às suas áreas específicas } \\
\text { de controle } \\
\text { Falta de infra-estrutura nos órgãos } \\
\text { ambientais } \\
\text { Ausência de implantação SISNIMA, nos } \\
\text { órgãos ambientais } \\
\end{array}$ & $\begin{array}{l}\text { Este problema que ocorre e } \\
\text { diz respeito aos órgãos } \\
\text { ambiental estadual, em } \\
\text { implantar o sistema. }\end{array}$ & $\begin{array}{l}\text { Implantação do banco de dados em } \\
\text { atendimento a legislação em vigor }\end{array}$ \\
\hline $\begin{array}{l}\text { Remuneração salarial, } \\
\text { capacitação dos } \\
\text { técnicos dos órgãos } \\
\text { ambientais e avaliação } \\
\text { do } \quad \text { EIA/RIMA } \\
\text { (equipes externas de } \\
\text { consultoria) }\end{array}$ & $\begin{array}{l}\text { Desenvolvimento } \\
\text { Socioeconômico }\end{array}$ & $\begin{array}{l}\text { Qualificação técnica } \\
\text { de consultores e dos } \\
\text { técnicos do governo }\end{array}$ & $\begin{array}{l}\text { Ausência de uma política salarial para os } \\
\text { técnicos dos órgãos ambientais } \\
\text { Falta de qualificação técnica por parte do } \\
\text { órgão ambiental } \\
\text { Ausência de conhecimentos técnico- } \\
\text { científicos dos profissionais envolvidos no } \\
\text { estudo }\end{array}$ & $\begin{array}{l}\text { Não ocorre no EIA/RIMA } \\
\text { da MSS, mas infere na } \\
\text { avaliação do estudo. }\end{array}$ & $\begin{array}{l}\text { Contratação de consultores externos } \\
\text { Implementação de um Programa de } \\
\text { Capacitação dos recursos humanos } \\
\text { Implantação de uma Política Salarial, } \\
\text { diferenciada das demais secretarias } \\
\text { estaduais }\end{array}$ \\
\hline $\begin{array}{l}\text { Relacionamentos entre } \\
\text { empreendedor, órgão } \\
\text { ambiental e entidades } \\
\text { de meio ambiente }\end{array}$ & & & $\begin{array}{l}\text { Dificuldade de parcerias entre } \\
\text { empreendedores e órgão ambiental }\end{array}$ & Não houve no caso da MSS & $\begin{array}{l}\text { Estreitar o relacionamento entre o } \\
\text { empreendedor, órgãos ambientais e } \\
\text { as entidades de meio ambiente }\end{array}$ \\
\hline $\begin{array}{l}\text { Carência de empresas } \\
\text { habilitadas }\end{array}$ & Resolução 001/86 & $\begin{array}{l}\text { Capacitação } \\
\text { profissionais } \\
\text { elaboração } \\
\text { EIA/RIMA }\end{array}$ & $\begin{array}{l}\text { Carências de empresas habilitadas na } \\
\text { elaboração de EIARIMA }\end{array}$ & $\begin{array}{l}\text { No caso da MSS, pois a } \\
\text { empresa veio do Estado de } \\
\text { Minas Gerais, com grande } \\
\text { experiência na área de } \\
\text { mineração, deixando } \\
\text { lacunas importantes na área } \\
\text { socioeconômica } \\
\end{array}$ & $\begin{array}{l}\text { Aumentar o número de profissionais } \\
\text { capacitados com experiências em } \\
\text { elaboração de EIA/RIMA, e em } \\
\text { levantamentos socioecoômicos }\end{array}$ \\
\hline $\begin{array}{l}\text { Divulgação e acesso } \\
\text { às informações dos } \\
\text { Estudos de Impacto } \\
\text { Ambiental }\end{array}$ & $\begin{array}{l}\text { Lei n } 6.938 \text {, de } 31 / 08 \\
\text { de } 1981 \text { - PNMA }\end{array}$ & $\begin{array}{l}\text { Falta de divulgação } \\
\text { das informações sobre } \\
\text { EIA/RIMA }\end{array}$ & $\begin{array}{l}\text { Ausência de divulgação dos pareceres } \\
\text { técnicos sobre o EIA/RIMA } \\
\text { Ausência em bibliotecas de pareceres } \\
\text { técnicos } \\
\text { Ausência de publicações que divulgassem } \\
\text { as decisões sobre os projetos analisados }\end{array}$ & $\begin{array}{l}\text { O EIA/RIMA da MSS } \\
\text { atendendo a legislação } \\
\text { ambiental vigente, ficou } \\
\text { apenas na biblioteca do } \\
\begin{array}{l}\text { órgão ambiental para } \\
\text { consulta }\end{array}\end{array}$ & $\begin{array}{l}\text { Que o Estado do Pará publique no } \\
\text { Diário Oficial os pareceres técnicos a } \\
\text { exemplo do que faz no Estado de São } \\
\text { Paulo }\end{array}$ \\
\hline
\end{tabular}

